\title{
Vitamin B-6 and aging : a rat study
}

Citation for published version (APA):

Bode, W. (1992). Vitamin B-6 and aging : a rat study. [Doctoral Thesis, Maastricht University]. Rijksuniversiteit Limburg. https://doi.org/10.26481/dis.19920508wb

Document status and date:

Published: 01/01/1992

DOI:

10.26481/dis.19920508wb

Document Version:

Publisher's PDF, also known as Version of record

\section{Please check the document version of this publication:}

- A submitted manuscript is the version of the article upon submission and before peer-review. There can be important differences between the submitted version and the official published version of record.

People interested in the research are advised to contact the author for the final version of the publication, or visit the DOI to the publisher's website.

- The final author version and the galley proof are versions of the publication after peer review.

- The final published version features the final layout of the paper including the volume, issue and page numbers.

Link to publication

\footnotetext{
General rights rights.

- You may freely distribute the URL identifying the publication in the public portal. please follow below link for the End User Agreement:

www.umlib.nl/taverne-license

Take down policy

If you believe that this document breaches copyright please contact us at:

repository@maastrichtuniversity.nl

providing details and we will investigate your claim.
}

Copyright and moral rights for the publications made accessible in the public portal are retained by the authors and/or other copyright owners and it is a condition of accessing publications that users recognise and abide by the legal requirements associated with these

- Users may download and print one copy of any publication from the public portal for the purpose of private study or research.

- You may not further distribute the material or use it for any profit-making activity or commercial gain

If the publication is distributed under the terms of Article $25 \mathrm{fa}$ of the Dutch Copyright Act, indicated by the "Taverne" license above, 


\section{Vitamin B-6 and aging: a rat study}

\section{PROEFSCHRIFT}

ter verkrijging van de graad van doctor aan de Rijksuniversiteit Limburg te Maastricht, op gezag van de Rector Magnificus, prof. mr. M.J. Cohen, volgens het besluit van het College van Dekanen, in het openbaar te verdedigen op vrijdag 8 mei 1992 om 14.00 uur

door

Wilhelmina Bode

geboren te Rotterdam 
Promotores:

prof. dr. ir. R.J.J. Hermus

prof. dr. D. L. Knook

Compromotor:

dr. H. van den Berg

Beoordelingscommissie: prof. dr. J. Jolles (voorzitter)

prof. dr. P.J. Brombacher

prof. dr. F. ten Hoor

prof. dr. W.H.P. Schreurs

prof. dr. P.B. Soeters

Studies reported in this thesis were carried out at the

TNO Toxicology and Nutrition Institute, Zeist, Netherlands.

Financial support for the publication of this thesis is gratefully acknowledged:

"TNO Nutrition and Food Research

Fonds Doctor Catharine van Tussenbroek

Nederlandse Organisatie voor Vrouwelijke Apothekers 
Aan mijn ouders 


\section{Woord vooraf}

Als reservestelling had ik in gedachten: onderzoek doe je nooit alleen, en zeker niet op TNO. Een groot aantal CIVOnezen plus personen van buiten het instituut hebben bijgedragen aan de totstandkoming van dit proefschrift.

Mijn promotor prof. R.J.J. Hermus en mijn copromotor dr. Henk van den Berg hebben indertijd het onderzoek 'Vitamine B-6 en veroudering' ingediend bij de Raad van Bestuur van TNO. Het project is opgezet in samenwerking met het IVEGTNO, waarbij vooral mijn tweede promotor prof. D. L. Knook en dr. Adriaan Brouwer betrokken waren. Het beschikbaar stellen van oude ratten en de hulp bij het uitvoeren van leverperfusie-experimenten kunnen hierbij met name genoemd worden.

Zo'n 21/2 jaar lang is goed voor de "B-6 dieren" gezorgd. Voor wat de inbreng betreft van de vaste verzorger Hans de Smit en al zijn vervangende en invallende collega's van de diervleugel, verwijs ik naar stelling 5 . Vermelding verdienen ook Inge de Rooy, Marion van Someren en Marcel Nederhoff voor het uitvoeren van de operaties. Ook met andere secties van de afdeling Biologische Toxicologie verliepen de contacten soepel. Er kon altijd wel iets tussendoor ingeroosterd worden. Al die "tussendoortjes' voor jullie hebben toch aardig wat bladzijden tekst van mij opgeleverd.

Voor wat betreft de analyse van de vele, vele monsters die werden verzameld steunt dit proefschrift voor een belangrijk deel op het werk verricht door twee personen. Op dat van Hans Mocking, die verantwoordelijk was voor zowel het opzetten als het uitvoeren van een groot aantal bepalingen en die op zijn geheel eigen wijze enthousiast assisteerde bij de dierexperimenten. Op dat van Ria Brustvan Schaik voor het zorgvuldig uitvoeren van grote series analyses en voor het corrigeren van de voorschriften om ze geschikt te maken voor routinematig werken. Maar ook alle andere collega's van de afdeling Klinische Biochemie hebben bijgedragen: door het uitvoeren van analyses (MiBi, HPLC) of door te helpen met allerlei klussen. En niet te vergeten vanwege het feit dat zij verantwoordelijk zijn voor de prettige sfeer waarin ik 4 jaar kon werken.

Met veel genoegen denk ik terug aan de discussies met mijn copromotor, Henk van den Berg, over het onderzoek, maar ook over onderwerpen (ver) daarbuiten. Naast Henk van den Berg hebben ook Adriaan Brouwer, Jaap Odink, Marga Kuijpers en Herman Koëter hun kritisch oog laten gaan over mijn onderzoekverslagen. Voor hun op- en aanmerkingen ben ik ze zeer erkentelijk. Dirk van der Heij moet speciaal genoemd worden voor de correctie van mijn vreselijk Amerikaanse Engels. Vanwege het verzorgen van de opmaak van mijn proefschrift, resulterende in $24 \%$ minder pagina's dan in mijn concept, zou ik hem eigenlijk ook bij de sponsors moeten vermelden. 
Door persoonlijke omstandigheden is dit proefschrift veel en veel later verschenen dan de bedoeling was. Gelukkig was daar de steun van familie, vrienden en collega's (waarbij de ene categorie de andere uiteraard niet uitsluit). Doordat jullie er in bleven geloven, is het me uiteindelijk gelukt. 


\section{Contents}

Abbreviations

Part I Introduction

Chapter 1 Outline of the thesis

Chapter 2 Vitamin B-6 and aging: a review

Ann NY Acad Sci 1990;585:96-105 (in part)

Chapter 3 Biokinetics in nutrition research

Chapter 4 Study design

Part II Biochemical approach of vitamin B-6 and aging

Chapter 5 Influence of age and sex on vitamin B-6 vitamer distribution and on vitamin B-6 metabolizing enzymes in Wistar rats

J Nutr 1991;121:318-29

Chapter 6 Influence of age and sex on vitamin B-6 vitamer distribution and on vitamin B-6 metabolizing enzymes in Brown-Norway rats

Part III Biokinetic approach of vitamin B-6 and aging

Chapter 7 Pyridoxal-5'-phosphate and pyridoxal biokinetics in aging Wistar rats

Exp Gerontol 1991;26: $589-99$

Chapter 8 Pyridoxal-5'-phosphate release from the isolated perfused rat liver after pyridoxal dosing: influence of age

Chapter 9 Lower retention of ${ }^{14}$ Clabel in old Wistar rats than in young ones after oral dosing of $\rrbracket^{14} \mathrm{C}$ pyridoxine J Nutr (accepted) 
Chapter 10 Effects of graded vitamin B-6 intake in a one-year feeding study in Wistar rats. Biochemical and functional consequences

Chapter 11 Pyridoxal-5'-phosphate and pyridoxal biokinetics in male Wistar rats fed graded levels of vitamin B-6 I Nutr 1991;121: 1838-45.

Chapter 12 Behavioral testing in nutrient research. Long-term graded vitamin B-6 intake in male and female Wistar rats

Part V Conclusion

Chapter 13 General discussion

Samenvatting

Curriculum vitae 


\section{Abbreviations}

AC activity coefficient

ALAT alanine aminotransferase

ALAT-AC alanine aminotransferase activity coefficient

AP alkaline phosphatase

ARE amount remaining to be excreted

ASAT aspartate aminotransferase

ASAT-AC aspartate aminotransferase activity coefficient

ATP adenosine triphosphate

AUC area under the (concentration-time) curve

AUMC area under the first moment (concentration-time) curve

BMDP biomedical computer program

BN Brown-Norway

BW body weight

$\mathrm{Cl}$ total plasma clearance

D dose

dll detection limit

DOP 4'-deoxypyridoxine

EASAT erythrocyte aspartate aminotransferase

EASAT-ACaythrocyte aspartate aminot ransferase activity coefficient

EGR erythrocyte glutathione reductase

EGR erythrocyte glutathione reductase activity coefficient

ery erythrocyte

FCR feed conversion efficiency

FMN flavine mononucleotide

ftr fractional turnover rate

GENSTAT general statistical program

GP glycogen phosphorylase

GP-a glycogen phosphorylase $a$

GP- $b \quad$ glycogen phosphorylase $b$

$\mathrm{Hb}$ hemoglobin

$\mathrm{Ht}$ hematocrit

$\mathrm{MCH} \quad$ mean corpuscular hemoglobin

$\mathrm{MCHC}$ mean corpuscular hemoglobin concentration

MCV mean corpuscular volume

MRT mean residence time

NAD nicotinamide dinucleotide 


$\begin{array}{ll}\text { NADP } & \text { nicotinamide dinucleotide phosphate } \\ \text { nd } & \text { not determined } \\ \text { NS } & \text { nonsignificant (in statistical test) } \\ \text { 4-PA } & \text { 4-pyridoxic acid } \\ \text { PL } & \text { pyridoxal } \\ \text { PLP } & \text { pyridoxal-5'-phosphate } \\ \text { PM } & \text { pyridoxamine } \\ \text { PMP } & \text { pyridoxamine-5'-phosphate } \\ \text { PN } & \text { pyridoxine } \\ \text { PNP } & \text { pyridoxine-5'-phosphate } \\ \text { RDA } & \text { recommended dietary allowance } \\ \text { SA } & \text { specific activity } \\ \text { SD } & \text { standard deviation } \\ \text { SDH } & \text { serine dehydratase } \\ \text { SDH-AC } & \text { serine dehydratase activity coefficient } \\ \text { SED } & \text { standard error of the difference between means } \\ \text { SEM } & \text { standard error of the mean } \\ { }_{1} 1 / 2 & \text { halflife } \\ t_{1 / 2} \text { el } & \text { halflife of elimination } \\ \text { TAT } & \text { tyrosine aminotransferase } \\ \text { TAT-AC } & \text { tyrosine aminotransferase activity coefficient } \\ \text { TRP } & \text { tryptophane } \\ \text { V } & \text { volume of distribution of the central compartment } \\ \text { V } & \text { total volume of distribution } \\ \text { W } & \text { Wistar } \\ \text { XA } & \text { xanthurenic acid }\end{array}$


Part I. Introduction 


\section{Outline of the thesis}

Observational studies into nutrient intake and nutrient status of elderly people indicate a low vitamin B-6 intake in combination with a marginal to deficient vitamin B-6 status in this age group. Indications have been brought forward that this marginal to deficient status is not attributable to a low vitamin B-6 intake allone. The facts produced so far are insufficiently conclusive to justify the recommended dietary allowance for vitamin B-6 to be raised for the elderly.

In order to broaden knowledge on the relation between vitamin B-6 and aging a rat study was started. Aims of this study were to elucidate the mechanism behind the well documented, age-related decrease in plasma pyridoxal-5"-phosphate concentration, and to study the functional consequences of a long-term low or marginal vitamin B-6 status. Selected results obtained in this rat study are presented in this thesis.

A general introduction, reviewing current knowledge on vitamin B-6 and aging, is given in Chapter 2. In Chapter 3 the possible advantages of the biokinetic approach in nutrient research over the traditional biochemical approach are discussed.

Chapter 4 provides a thorough description of the experimental animals used in the various studies presented in Chapters 5-12.

Experiments with an emphasis on the biochemistry of vitamin B-6 in relation to aging are presented in Part II, Chapters 5 and 6. Part III, Chapters 7-9, reports experiments based on the biokinetic instead of the biochemical approach to study the same subject. Part IV, Chapters 10-12, summarizes some of the results of studies into the functional consequences of long-term low vitamin B-6 intake. Finally, a general discussion is presented in Part V, Chapter 13, with remarks on the possible extrapolation of results obtained with the experimental animals to the human situation. 


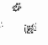




\section{Vitamin B-6 and aging: a review}

\section{Abstract}

In this paper the literature on vitamin B-6 and (human) aging is reviewed. In observational studies on the biochemical vitamin B-6 status of the elderly, a high incidence of marginal to deficient status for vitamin B-6 parameters is invariably found. This cannot be explained by a lower vitamin B-6 intake alone. The results of some human and animal studies are suggestive of the occurrence of age-dependent changes in vitamin B-6 metabolism and kinetics. However, up to now insufficient data are available to adjust vitamin B-6 recommended dietary allowance for the elderly. The relation between vitamin B-6 and aging needs further study.

\section{Introduction}

\section{Rationale of research on nutrition and aging}

Various estimations indicate that the percentage of elderly people in Western societies will increase substantially in the years to come. In 1986, 12.3\% of the Dutch population was older than 65 years. It has been estimated that this proportion will increase to approximately $21 \%$ in 2030 [1]. The numbers for the USA are comparable: an increase from $11.5 \%$ in 1985 to an estimated $21.5 \%$ in 2030 [2]. With life expectancy increasing, quality of life, i.e. maintaining health and function as late as possible in life, becomes more and more important. Increasing evidence points to a role of nutrition in the occurrence of, susceptibility to, and possibly prevention of chronic and degenerative diseases.

\section{Definition of aging}

Aging is accurately described as the sum of all changes occurring with time in living organisms between conception and death. In this definition no distinction is made between changes related to fetal and postnatal development, maturation, adaptations, diseases, or degenerative processes. It is not possible yet to distinguish between age-related changes attributable to aging and other processes. Also, this definition includes the possibility that the aging process is operative not only during the later part of life, but also during earlier stages [3]. A definition that is less broad, that fits better in with the purpose of this review, and that represents more closely the 
sentiment of (Western) society is the one formulated by Makinodian: aging is the agedependent process finally resulting in impaired capacity of the intact organism to respond to external stimuli, which is associated with an increased mortality rate [4].

The influence of nutrition on the aging process and, vice versa, the influence of age-related changes of physiological functions on nutritional needs, are as yet largely unknown. The impact of age-related changes in physiology and metabolism has been assessed extensively in pharmacological research. Comparatively little research has been performed to define the impact of these changes on human nutrient requirement. Health and well-being of the elderly reflect interactions between dietary factors, physiological as well as pathological processes and (changes in) life-style $[5,6]$. Interest in the interdependent nature of aging, nutrition and health is increasing.

\section{Consequences of physiological aging on nutrition of the elderly}

Aging is associated with a qualitative and quantitative alteration in bodly composition and organ function. The most striking example is the progressive reduction of lean body mass with a compensatory accumulation of adipose tissue during the adult lifespan $[7,8]$. The decrease in function of various organs results in a less adequate homeostatic response to envirormental changes. This may give rise to the observed high incidence of non-specific symptoms and multiple pathology, and of chronic diseases, such as diabetes, hypertension and cancer, in elderly people. Evidence is also accumulating that the elderly are more susceptible to some infectious diseases. Furthermore, some infections are associated with increased mortality in the aged. Not surprisingly, the aged use large amounts of a variety of drugs, drug use increasing with age. In a survey on drug use among elderly Americans it was found that the percentage of elderly using no drugs decreased with age from 30.1 (60-69 years of age) to 5.4 (over 80 years of age). The percentage of elderly using 5 or more different drugs per day increased with age from $16.8(60-69 \mathrm{y})$ to $48.6(>80 \mathrm{y})$ [9].

Some age-related factors may have a detrimental influence on the nutritional status of elderly people [10, 11]. Because of poor mobility, buying food, cooking it and possibly even eating it may pose formidable problems. The elderly appear to be prone to memory deficits and poor intellectual function. Appetite may fade because of reduced smell and taste acuity. Dental health is usually poor, and dental protheses are common, resulting in chewing problems. Gastrointestinal tract changes that may occur are achlorhydria, pepsinogen deficiency, reduced pancreatic secretion, reduced intestinal surface area (possibly counterbalanced by a slower small bowel transit time) and constipation. On the whole, the impact of these gastrointestinal tract changes on the nutritional status of the elderly is probably limited, but in individuals already compromised by other factors they could become of major importance. Last but not least, the aforementioned large and multiple drug consumption may have a negative impact on nutritional status.

Interpretation of age effects is complicated by the observed increasing morbidity with aging. An increased tendency to develop diseases may be a universal 
phenomenon in aging organisms. However, any interference of pathology should be excluded, ideally, in aging research.

\section{Characteristics and function of vitamin B-6}

\section{Characteristics}

Vitamin B-6 is the generic name for a group of 3-hydroxy-2-methylpyridine-derived compounds, exhibiting qualitatively the biologic activity of pyridoxine in rats. It comprises several vitamers: pyridoxine (PN), pyridoxal (PL) and pyridoxamine (PM) and their 5'-phosphorylated derivatives, pyridoxine-5'-phosphate (PNP), pyridoxal5 '-phosphate (PLP) and pyridoxamine-5'-phosphate (PMP), respectively (Fig. 1). The major excretory metabolite of vitamin B-6 is 4-pyridoxic acid (4-PA) which has no biological activity. The various forms of the vitamin (vitamers) are readily soluble in water and slightly soluble in ethanol. $\mathrm{PN}$ (as $\mathrm{HCl}$ salt) is fairly heat-stable, but not stable in moist heat (e.g. during food processing). All forms of vitamin B-6 are highly unstable in visible and ultraviollet light, especially in neutral or alkaline solution.<smiles>C[13CH2][13CH3]</smiles>

4-pyridoxic acid (4PA)<smiles>Cc1ncc(CO)c(CO)c1O</smiles><smiles>Cc1ncc(CO)c(C=O)c1O</smiles>

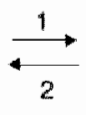

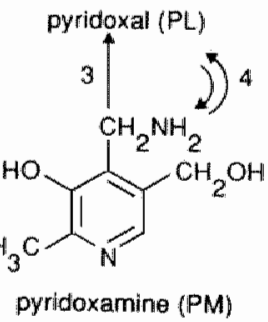
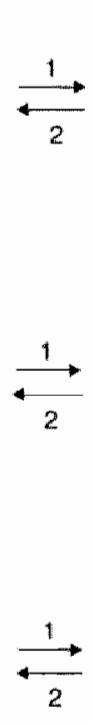<smiles>Cc1ncc(COP)c(O)c1O</smiles><smiles>[CH]1CCC1</smiles><smiles>Cc1ncc(COP)c(C=O)c1O</smiles>

pyridoxal 5'-phosphate (PLP)<smiles>Cc1ncc(CN)c(CN)c1O</smiles>

pyridoxamine $5^{\prime}$ - phosphate (PMP)

Fig. 1. Metabolism of witamin B-6. 1, PL-kinase; 2, (alkaline) phosphatase; 3, PMP-oxidase; 4, transaminase; 5 , aldehyde oxidase/dehydrogenase. 
Vitamin B-6 is widespread in foods. Rich sources of vitamin B-6 are meats, fish, whole-grain products, nuts, legumes and leafy vegetables. The main vitamer found in plant products is $\mathrm{PN}$, of which a substantial proportion $(5-70 \%)$ is present as PN-13-glucoside [12]. In animal products, vitamin B-6 is largely present as proteinbound PIJP and PMP. Food processing usually decreases the availability of vitamin $B-6$, owing to heat instability or reaction of PL with protein or amino acids to form $\mathrm{PL}-\mathrm{ysine}[13] . \mathrm{PN} \cdot \mathrm{HCl}$ is used in fortified foodstuffs and pharmacologic formulations because of its heat stability.

\section{Metabolism and biokinetics}

Orally ingested vitamin B-6 is rapidly absorbed in the upper intestinall tract. The unphosphorylated vitamers PN, PM and PL are mainly absorbed by passive diffusion $\{1417\}$. The phosphorylated forms PLP and PMP are largely hydrolyzed to PL and $P M$, respectively, by intraluminal alkaline phosphorylase (nonspecific alkaline phosphatase, EC 3.1.3.1) [15-19]. A small proportion of ingested PLP and PMP is absorbed intact. In the intestinal wall phosphorylative trapping takes place of the absorbed unphosphorylated compounds, catalyzed by the enzyme PL-kinase (ATP:pyridoxal-5'-phosphorransferase, EC 2.7.1.35). Only the remaining unphosphorylated vitamers are transported to the serosal surface of the intestinal wall [20].

Bioavailability of vitamin B-6 in food is influenced by food composition and food processing. The main B-6 vitamer found in plant products is PN of which 5-70\% is present as $\mathrm{PN}-\beta-\mathrm{glucoside}$ [12]. In rat studies bioavailability of the glycosylated form was observed to be lower than that of pure PN $[21,22]$. Bioavailability of PN from dietary glycosylated PN in man was estimated to be $60 \%$, indicating PN-B-glucoside is not completely utilized [23]. PL-lysine, which is the reaction product of PL with lysine (free or in protein) formed during heating, is only partly utilized and shows anti-vitamin B-6 activity [13]. Compared to pure PN, the bioavailability of vitamin B-6 in an average American diet was calculated to be $61-81 \%$ (mean $71 \%$ ) on the basis of plasma levels reached after dosing, and $73-92 \%$ (mean $79 \%$ ) on the basis of urinary excretion data $\mid 24\}$.

Contlicting results have been obtained concerning the influence of dietary polysaccharides on vitamin B-6 bioavailability. In rat studies, increased bioavailability has been ascribed to increased vitamin B-6 synthesis by the intestinal flora $[25,26]$. On the other hand, rats with an adequate B-6 status were found not to utilize intestinal B-6 [27]. In a human study on the influence of different types of bread, it was observed that vitamin $B-6$ is $5-10 \%$ less available from whole-wheat bread than from white bread enriched with vitamin B-6 [28]. By contrast, there appeared to be no adverse influence of increased crude fiber intake when comparing vegetarian to control women $[29,30]$. In vitro binding of vitamin B-6 to polysaccharides, lignin and wheat bran was not observed $[31 \mid$.

The various forms of vitamin B-6 found in animal tissue can be converted, which is illustrated in Fig. 1 [32]. The unphosphorylated vitamers PN, PM, and PL present 
in the portal circulation readily cross cell membranes and are all taken up by the liver. In the cell, phosphorylative trapping takes place by conversion to PNP, PMP and PLP, respectively, catalyzed by PL-kinase. PL-kinase activity has been demonstrated in all mammalian tissues examined so far. Another enzyme involved in vitamin B-6 metabolism is the flavoprotein PMP-oxidase (pyridoxamine- 5 phosphate:oxygen oxidoreductase, EC 1.4.3.5). It catalyzes the conversion of PNP and PMP to PLP. The activity of this enzyme is high in liver, but low or absent in other tissues. Therefore it is assumed that the liver is the major site of vitamin B-6 metabolism. Interconversion of PLP and PMP (and of PL and PM) is catalyzed by transaminases. The phosphate esters are dephosphorylated by (membrane-bound) alkaline phosphorylase. Pyridoxal is oxidized by a nonspecific aldehyde oxidase (aldehyde:oxygen oxidoreductase, EC 1.2.3.1) or an NAD-dependent dehydrogenase (aldehyde:NADP ${ }^{+}$oxidoreductase, EC 1.2.1.4) to 4-PA. This is an irreversible reaction, and 4-PA is the major excretory form of vitamin B-6. In man, the aldehyde oxiclase appears to be mainly responsible for PL degradation |33|.

Transport of vitamin B-6 among the various organs is provided by blood. PL.P is the main vitamer present in plasma, in the form of an albumin-PLP complex [34]. Plasma PLP bound to albumin primarily derives from the liver [35]. Binding to albumin protects PLP against hydrolysis, but it also prevents transport into cells. PL, on the other hand, is readily transported across cell membranes. Unbound PLP is very susceptible to hydrolysis by alkaline phosphorylase. Tissues other than liver are assumed to take up vitamin B-6 by extracellular dephosphorylation of PLP, followed by facilitated difusion of PL into the cell through intracellular phosphorylation [36].

PLP content of liver, and probably of other organs as well, is strictly regulated by protein binding, hydrolysis of unbound PLP by alkaline phosphatase, competition for (free) PL between PL-kinase and PL-oxidating enzymes, and (liver only) product inhibition of PMP(PNP)-oxidase by free PLP $[32,36]$. Plasma PLP level is probably controlled by the equilibrium between synthesis of albumin-bound PLP, mainly in the liver, and hydrolysis of unbound PLP by alkaline phosphatase. The overall capacity of the body to hydrolyze circulating PLP is very large. In an organ ablation study on dogs it was found that neither hepatectomy, nephrectomy, nor the combined removal of stomach, intestines and spleen had any influence on PLP clearance from plasma. Also, the phosphorylative capacity of plasma and blood cells was found to be too low to account for the fast removal of administered PLP [37]. The most conclusive evidence for the control of plasma PLP levels by alkaline phosphatase was reported in studies of patients with hypophosphatasia. Hypophosphatasia is an congenital error, characterized by, among other things, low serum alkaline phosphatase, high pyrophosphate and high phosphoethanolamine levels in plasma. In patients plasma PLP levels ranged from 214 to $3839 \mathrm{nmol} / \mathrm{l}$ (mean $1.174 \mathrm{nmol} / \mathrm{l}$ ), compared to $57 \pm 26 \mathrm{nmol} / /$ in control subjects [38].

Muscle has a relatively thigh PLP content, of which $60 \%$ or more is associated with the enzyme glycogen phosphorylase $(1,4-\alpha$-D-glucan:orthophosphate- $\alpha$ glucosyltransferase, EC 2.4.1.1). As muscle comprises approximately $40 \%$ of total body mass, muscle glycogen phosphorylase PLP is considered to be the main vitamin 
B-6 depository [39]. However, it has been demonstrated that PLP is released from muscle only during starvation, not during vitamin B-6 deficiency per se [40]. In recent human studies it was shown that plasma PLP levels rise after a bout of (strenuous) exercise, returning to baseline levels in about $60 \mathrm{~min}[41-43]$. Muscle glycogen phosphorylase was considered to be the most plausible source of PLP released, as the effect of exercise on muscle tissue might be comparable to that of acute starvation.

Of the total amount of vitamin B-6 ingested roughly half is excreted into urine as 4-PA [44-46]. Data from animal experiments suggest that biliary excretion and enterohepatic circulation only play a minor role in overall vitamin B-6 biokinetics [47]. After oral administration of radiolabelled vitamin B-6 to rats, fecal excretion of ingested label is low ( $10 \%$ or less), the remainder being excreted into urine /see e.g. $22,27]$.

\section{Function}

Vitamin B-6 is an essential nutrient, required for growth and development of normal tissues in all species of animals studied to date. The metabolically active form of vitamin $\mathrm{B}-6$ is PLP, although PMP is active in aminotransferases as well.

PLP serves as a coenzyme in several metabolic reactions, especially in those related to amino acid metabolism. PLP is highly reactive to amino acids and other nitrogenous compounds and readily forms a Schiff base with amino acid substrates (for a review on the role of vitamin B-6 in anino acid metabolism see ref. 48 ). The most important PLP-dependent enzymatic reactions are transamination and decarboxylation. Aminotransferases function in both amino acid biosynthesis (nonessential amino acids) and in amino acid catabolism (gluconeogenesis). Via transamination and one-carbon metabolism PLP is involved in immune function. Decarboxylases are involved in the synthesis of several neurotransmitters, i.e. $y$-aminobutyric acid (GABA), epinephrine (adrenaline) and norepinephrine (noradrenaline). Glycogen phosphorylase, the enzyme initiating the catabolism of glycogen, contains PLP as a coenzyme $[49,50]$. Here PLP coenzyme function appears to be different from PLP function in amino acid metabolism: probably the phosphate group is involved in its actual coenzymatic role $[50,51]$. Unrelated to coenzyme function is the influence of PLP on sensitivity of steroid hormone receptors $[52,53]$.

Clinical vitamin B-6 deficiency signs described in humans are abnormal electroencephalogram pattern and convulsions (reported to occur in infants) and cheilosis, glossitis, stomatitis, hyperirritability, depression and confusion (primarily in adults). Dietary vitamin B-6 deficiency severe enough to result in clinical signs is unlikely because of the omnipresence of vitamin B-6 in foods. However, subclinical deficiency may occur. Vitamin B-6 deficiency signs have been thoroughly described in the rat, the animal most frequently used experimental in nutrition research. Besides a large variety of biochemical lesions, the deficiency signs most frequently encountered are acrodynia (symmetrical scaling dermatitis) on tail, paws, nose, chin 
and upper thorax; poor growth, eventually resulting in weight loss; and, with B-6 deficiency induced in utero or during lactation, neural degeneration, leading to convulsive seizures, neuronal dysfunction, eventually followed by death. Epileptiform seizures, both in rat pups and in human infants, are believed to be caused by low GABA levels in the brain [54].

In a recent review conditions are discussed associated with a low vitamin B-6 status in humans [55]. These include hematologic disorders ('pyridoxine-responsive' anemia), atherosclerosis, aberrant sulfur amino acid metabolism (homocysteinemia), neurological disorders, collagen disorders and cancer. Pregnancy, lactation and oral contraceptive use also have been connected to lowered vitamin B-6 status.

Table 1. Vitamin B-6 intake of elderly people.

\begin{tabular}{|c|c|c|c|c|c|c|c|}
\hline \multirow[t]{2}{*}{ Population' } & \multirow[t]{2}{*}{$n^{2}$} & \multicolumn{2}{|c|}{ Defined deficient intake } & \multirow{2}{*}{$\begin{array}{l}\text { Deficiency } \\
\text { (\% of pop- } \\
\text { ulation) }\end{array}$} & \multicolumn{2}{|c|}{ Actual mean iniake } & \multirow[t]{2}{*}{ Ref. } \\
\hline & & $\begin{array}{l}\text { (relative } \\
\text { to } 1980 \mathrm{RDA} \text { ) }\end{array}$ & (mg/day) & & (mg/day) & $\begin{array}{l}(\mu \mathrm{g} / \mathrm{g} \\
\text { protein) }\end{array}$ & \\
\hline$H_{n} M+W_{n} \geq 65 y$ & 102 & $\begin{array}{l}<1 / 3 \mathrm{RDA} \\
<1 / 2 \mathrm{RDA}\end{array}$ & $\begin{array}{l}<0.7 \\
<1\end{array}$ & $\begin{array}{l}18.6 \\
78.4\end{array}$ & 0.84 & 16.2 & 59 \\
\hline $\begin{array}{l}\mathbb{H}_{*} \mathrm{M}+\mathrm{W}_{4} \geq 65 \mathrm{y} \\
\mathbb{F}, \mathrm{M}+\mathrm{W}_{1} \geq 65 \mathrm{y}\end{array}$ & $\begin{array}{r}143 \\
53\end{array}$ & $\begin{array}{l}<2 / 3 \mathrm{RDA} \\
<2 / 3 \mathrm{RDA}\end{array}$ & $\begin{array}{l}<1.4 \\
<1.4\end{array}$ & $\begin{array}{l}95.1 \\
84.9\end{array}$ & 0.88 & 17.0 & 60 \\
\hline $\begin{array}{l}F, M_{1} \geq 60 y \\
F, W, \geq 60 y\end{array}$ & $\begin{array}{l}125 \\
145\end{array}$ & $\begin{array}{l}<1 / 2 \mathrm{RDA} \\
<1 / 2 \mathrm{RDA}\end{array}$ & $\begin{array}{l}<1.1 \\
<1\end{array}$ & $\begin{array}{l}54 \\
61\end{array}$ & $\begin{array}{l}1.97 \\
0.93\end{array}$ & $\begin{array}{l}12.9 \\
13.9\end{array}$ & {$[61]$} \\
\hline $\begin{array}{l}\text { 1. } M_{4} \geq 60 y \\
\text { I. } W, \geq 60 y\end{array}$ & $\begin{array}{l}31 \\
29\end{array}$ & $\begin{array}{l}<1 / 2 \mathrm{RDA} \\
<1 / 2 \mathrm{RDA}\end{array}$ & $\begin{array}{l}<1.1 \\
<1\end{array}$ & $\begin{array}{l}48 \\
55\end{array}$ & $\begin{array}{l}1.04 \\
1.02\end{array}$ & $\begin{array}{l}18 \\
18\end{array}$ & 62 \\
\hline $\begin{array}{l}\text { F.M, }, 60-69 y \\
\text { F, M, 70-79y } \\
\text { F, M, } \geq 80 y \\
\text { F, W, 60-69y } \\
\text { F. W, } 70-79 y \\
\text { F. W, } \geq 80 y\end{array}$ & $\begin{array}{r}100 \\
97 \\
42 \\
158 \\
177 \\
117\end{array}$ & $\begin{array}{l}<2 / 3 \mathrm{RDA} \\
<2 / 3 \mathrm{RDA} \\
<2 / 3 \mathrm{RDA} \\
<2 / 3 \mathrm{RDA} \\
<2 / 3 \mathrm{RDA} \\
<2 / 3 \mathrm{RDA}\end{array}$ & $\begin{array}{l}<1.5 \\
<1.5 \\
<1.5 \\
<1.3 \\
<1.3 \\
<1.3\end{array}$ & $\begin{array}{l}63 \\
67 \\
74 \\
70 \\
75 \\
74\end{array}$ & $\begin{array}{l}1.42 \\
1.35 \\
1.19 \\
1.13 \\
1.09 \\
1.08\end{array}$ & $\begin{array}{l}16.7 \\
17.5 \\
15.9 \\
16.9 \\
17.0 \\
16.9\end{array}$ & [63] \\
\hline $\begin{array}{l}\mathbb{F}, \mathbb{M} \geq 65 y \\
\mathbb{F}, W, \geq 6.5 y\end{array}$ & $\begin{array}{l}269 \\
269\end{array}$ & $\begin{array}{l}<3 / 4 \mathrm{RDA} \\
<3 / 4 \mathrm{RDA}\end{array}$ & $\begin{array}{l}<1.7 \\
<1.5\end{array}$ & $\begin{array}{l}68 \\
88\end{array}$ & $\begin{array}{l}1.38 \\
1.15\end{array}$ & $\begin{array}{l}17 \\
17\end{array}$ & $|64|$ \\
\hline $\begin{array}{l}F, M, \geq 60 y \\
F, W, \geq 60 y\end{array}$ & $\begin{array}{r}60 \\
138\end{array}$ & $\begin{array}{l}<1 / 2 \mathrm{RDA} \\
<1 / 2 \mathrm{RDA}\end{array}$ & $\begin{array}{l}<1.1 \\
<1\end{array}$ & $\begin{array}{r}5 \\
17\end{array}$ & $\begin{array}{l}1.9 \\
1.5\end{array}$ & $\begin{array}{l}23 \\
23\end{array}$ & $|6.5|$ \\
\hline $\begin{array}{l}F_{1} M(W)>65 y \\
F_{n} M(B),>65 y \\
F_{.} W(W),>65 y \\
F, W(B),>65 y\end{array}$ & $\begin{array}{r}882 \\
104 \\
1059 \\
124\end{array}$ & $\begin{array}{l}- \\
- \\
- \\
-\end{array}$ & $\begin{array}{l}- \\
- \\
-\end{array}$ & $\begin{array}{l}- \\
- \\
-\end{array}$ & $\begin{array}{l}1.57 \\
1.19 \\
1.13 \\
0.89\end{array}$ & $\begin{array}{l}22 \\
20 \\
23 \\
21\end{array}$ & $|66|$ \\
\hline
\end{tabular}

IF, free-living; $H$, hospitalized; I, institutionalized; $M$, men; $W$, women; (B), black; (W), whitc.

zumber of volunteers studied. 


\section{Vitamin B-6 intake of elderly people}

PLP-catalyzed reactions are of central importance in overall nitrogen metabolism. The requirement for vitamin B-6 increases as the intake of protein increases [56]. Therefore the 1980 recommended dietary allowance (RDA) for vitamin B-6 is based on protein intake: $20 \mu \mathrm{g} / \mathrm{g}$ protein [57]. Based on actual average protein intake among adults in Westerm societies the vitamin B-6 RDA is $2.2 \mathrm{mg} /$ day for men and $2.0 \mathrm{mg} /$ day for women. Observational studies on vitamin B-6 intake indicate that many elderly people have vitamin B-6 intakes below the 1980 RDA (see Table 1). Recently the 10th edition (1990) of the RDA has been issued. Compared to the 1980 edition, the RDA for vitamin B-6 was lowered to $16 \mu \mathrm{g} / \mathrm{g}$ protein consumed, because at this intake level vitamin B-6 status parameters were observed to be acceptable in adults [58]. Possible differences between requirements for adults and those for the elderly have not been discussed. Using $16 \mu \mathrm{g} / \mathrm{g}$ protein as a cut-off level, dietary vitamin B-6 intake appears to be adequate in most elderly populations studied (Table 1).

Dietary vitamin B-6 intakes calculated from dietary records are as accurate as the nutrient database for vitamin B-6 used. Vitamin B-6 data are incomplete to some extent, which might cause differences between surveys. On the other hand, available vitamin B-6 could be overestimated due to the fact that, for vitamin B-6 concentrations in foodstuffs, the nutrient database does not differentiate between glycosylated and nonglycosylated vitamers. Furthermore, correction for vitamin B-6 losses due to food processing may not have been incorporated.

\section{Vitamin B-6 status assessment of elderly people}

\section{Plasma pyridoxal-5'-phosphate}

Measurement of plasma PLP concentration is widely used in biochemical vitamin B-6 status assessment [67|. The plasma level of the metabolically active vitamin B-6 vilamer seems to provide a reasonable indication of the underlying nutritional status. However, it is markedly affected by recent (dietary) vitamin B-6 intake. Furthermore, plasma PLP levels increase in prolonged fasting and (temporarily) after strenuous exercise $|40-43|$. Acute ingestion of glucose has been observed to decrease plasma PLP concentration [68]. A causal inverse relationship has been suggested between plasma alkaline phosphatase (EC 3.1.3.1) activity and plasma PLP concentration [69]. Patients with hypophosphatasia show extremely high plasma PLP levels, while in patients with liver or skeletal disease, the higher plasma alkaline phosphatase activity is generally associated with lower plasma PLP levels.

In several observational studies on vitamin B-6 status of elderly people plasma PLP was found to be lower with increasing age (see Table 2). Rose et al. determined plasma PLP in 617 healthy noninstitutionalized men, aged 18 to 90 [71]. A statistically significant decline of $3.6 \mathrm{nmol} / 1$ per decade was reported in 
Table 2. Vitamin B-6 status assessment of elderly people.

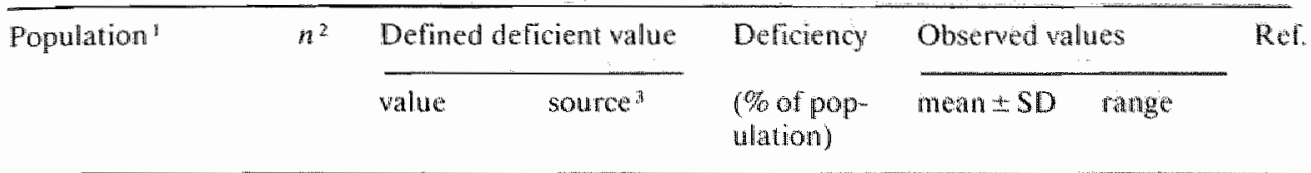

Plasma PLP concentration (nmolil)

\begin{tabular}{|c|c|c|c|c|c|c|}
\hline 1. $M+W, \geq 66 y$ & 45 & $<6$ & RP & 33 & $25 \pm 13$ & - \\
\hline$F, M_{3} \geq 60 y$ & 148 & $<19$ & $?$ & 9 & - & - \\
\hline $\begin{array}{l}F, M_{1} \geq 65 y \\
F, W_{,} \geq 65 y\end{array}$ & $\begin{array}{l}47 \\
42\end{array}$ & $<20$ & RP & $32(M+F)$ & $\begin{array}{l}24 \pm 1 \\
33 \pm 17\end{array}$ & - \\
\hline$F, M+W, \geq 60 y$ & 198 & $<32$ & $\mathrm{~L}$ & 32 & \multicolumn{2}{|c|}{$\begin{array}{l}34 \pm 22 \text { (nonsuppl) } \\
1.45 \pm 122(\text { suppl) }\end{array}$} \\
\hline $\begin{array}{l}\text { I. } M, \geq 60 y \\
\text { I. }, \geq 20 y\end{array}$ & $\begin{array}{l}31 \\
29\end{array}$ & $\begin{array}{l}<80 \\
<80\end{array}$ & $\mathrm{~L}$ & $\begin{array}{l}71 \\
86\end{array}$ & $\begin{array}{l}69 \pm 15 \\
52 \pm 4\end{array}$ & $\begin{array}{l}7-190 \\
21.120\end{array}$ \\
\hline
\end{tabular}

1701

Erythocye ASAT-AC (ratio)

\begin{tabular}{|c|c|c|c|c|c|c|c|}
\hline $\mathrm{I}, \mathrm{M}+\mathrm{F}, \geq 66 \mathrm{y}$ & 45 & $>2.28$ & RP & 9 & $1.96 \pm 0.5$ & - & $|70|$ \\
\hline$F, M+F, \geq 64 y$ & 198 & $>2.28$ & $\mathrm{RP}$ & 26 & $2.01 \pm 0.24$ & - & \\
\hline I. $M+F, \geq 60 y$ & 153 & $>2.213$ & L & 10 & 1.86 & - & $|73|$ \\
\hline$F, M+F, \geq 60 y$ & 212 & $>2.213$ & L & 7 & 1.88 & - & \\
\hline$F, M, \geq 65 y$ & 221 & 32.02 & $?$ & $9(M+F)$ & $1.71 \pm 0.21$ & - & 1721 \\
\hline$F, W, \geq 65 y$ & 206 & & & & $1.75 \pm 0.21$ & - & \\
\hline $1, M, \geq 60 y$ & 31 & $>2.0$ & $\mathscr{L}$ & 71 & $2.08 \pm 0.10$ & $1.41-3.11$ & {$[62]$} \\
\hline I. $W, \geq 60 y$ & 29 & $>2.0$ & $\mathbb{L}$ & 86 & $2.10 \pm 0.07$ & $1.58-3.71$ & \\
\hline$I, M+W, \geq 65 y$ & 153 & $>1.86$ & $\mathbb{R P}$ & 19 & $-\ldots$ & $1.24-2.38$ & $174 !$ \\
\hline$F, M+W, \geq 60 y$ & 150 & $>1.80$ & $?$ & $<2,5$ & - & - & $\lceil 75\rceil$ \\
\hline$F, M, \geq 60 y$ & 139 & - & - & - & 1.93 & - & 711 \\
\hline
\end{tabular}

Erythrocyle ALAT-AC (ratio)

\begin{tabular}{lrllllll|}
$H, M+W, \geq 65 y$ & 102 & $>1.15$ & L & 28 & - & - & $\mid 59 \|$ \\
H. M+W, $\geq 65 y$ & 143 & $>1.15$ & L & 41 & 1.15 & - & $|60|$ \\
$F, M+F, \geq 65 y$ & 53 & $>1.15$ & L & 47 & 1.18 & - &
\end{tabular}

' F, free-living: $H$, hospitalized; $L$, institutionalized; $M$, men; $W$, women.

2 L. obtained from the literature; RP, 2.5 (or p97.5) of young adult reference population; ? unknown source.

${ }^{3}$ In this elderly population $\mathrm{p} 97.5<1.80$. 
nonsupplemented men. Plasma PLP tevels of men taking a vitamin B-6 supplement also showed a tendency to decrease. The age-related decline was most apparent in the 80 to 90 age bracket; plasma PLP levels found there were only half of the levels found in the 18 to 29 age group. The average plasma PLP levels of the men not taking supplements was $50 \pm 1 \mathrm{nmol} / \mathrm{l}$, with $25 \%$ of the values being lower than $30 \mathrm{nmol} / \mathrm{l}$. For the men taking a vitamin B-6 supplement, plasma PLP averaged $83 \pm 4 \mathrm{nmol} / \mathrm{l}$, with only $8 \%$ below $30 \mathrm{nmol} / \mathrm{l}$. In a more recent study, a relatively high plasma PLP level was observed at young age, a lower but constant level in mid-life, and a further decrease at older age [76]. In a recent study on Dutch apparently healthy free-living elderly, a fairly widespread deficient vitamin B-6 status was found [72]. Plasma PLP levels averaged $27 \mathrm{nmol} / \mathrm{l}$ in elderly Dutch men, with $43 \%$ being below the P2.5 of healthy young adult blood donors $(20 \mathrm{nmol} / 1)$. In elderly Dutch women the average plasma PLP level was $45 \mathrm{mmol} / \mathrm{l}$, with only $13 \%$ lower than $19 \mathrm{nmol} / \mathrm{l}$.

Interpretation of plasma PLP concentrations in terms of deficient or adequate witamin B-6 status is hampered by the fact that no generally accepted range of adequate or deficient values has been defined. Obviously, the percentage of elderly people observed to be vitamin B-6 deficient, therefore, is highly dependent on classification of the plasma PLP levels measured (Table 2).

\section{Urinary 4-pyridoxic acid excretion}

Urinary excretion of the metabolic end-product 4-PA is used as a noninvasive vitamin B-6 status parameter. However, urinary 4-PA excretion reflects vitamin B-6 intake rather than the underlying vitamin B-6 tissue reserves [77]. Nevertheless, low urinary excretion of 4-PA (for example below $2.5 \mu \mathrm{mol}$ per 24 hours) implies low vilamin $B-6$ intake.

When studying young and middle-aged women on controlled dietary intake of vitamin B-6 with respect to excretion of 4-PA into urine, the older women showed slightly higher urinary 4-PA excretion than the younger women [44]. However, in a recent study comprising of three male age groups no difference in urinary excretion after an oral vitamin B-6 load could be demonstrated [46].

\section{Coenzyme saturation tests in vitro}

Vitamin B-6 deficiency can be expected to cause a larger percentage of PLPdependent enzymes to be present as the catalytically inactive apo-enzymes. Any apoenzyme present can be converted to the catalytically active holo-enzyme by in vitro incubation with a saturating concentration of PLP. Comparing enzyme activity with and without prior PLP incubation of the reaction mixture permits determination of the proportion of apo-enzyme originally present. The results are usually expressed as an activation coefficient ( $\mathrm{AC}$ ), calculated as the ratio of enzyme activity with and without PLP added. 
For the assessment of vitamin B-6 status on the basis of coenzyme saturation two aminotransferases present in erythrocytes are most frequently used: alanine aminotransferase (ALAT, EC 2.6.1.12) and aspartate aminotransferase (ASAT, EC 2.6.1.1). Erythrocyte AC reflects the availability of PLP at the time the cells are released into the circulation, because in mature erythrocytes no protein synthesis occurs.

Vitamin B-6 status assessment of elderly people by erythrocyte ALAT or ASAT activity coefficient (EALAT-AC and EASAT-AC, respectively) shows conflicting results. This is at least partly caused by the lack of generally accepted ranges of adequate and deficient values (Table 2). Some researchers have found a high incidence of biochemical deficiency among the elderly. In a heterogeneous elderly population, $42.3 \%$ deficient values (EALAT-AC > 1.15) were found [60]. A survey of institutionalized elderly showed $70 \%$ incidence of inadequate vitamin B-6 status (EASAT-AC $>2$ ), as opposed to 12\% in young healthy adults [62]. On the other hand, when EASAT-AC of healthy free-living elderly is compared to that of healthy, adult blood donors, only $1-2 \%$ of the elderly show a relatively high $(>2.28)$ value [72]. A population of geriatric patients showed an incidence of high EASAT-AC $(>1.86)$ of 'only' $19 \%[74]$.

Age-related changes in vitamin B-6 status as assessed by coenzyme saturation tests are not always congruent with plasma PLP concentration findings. In a cohort of 617 healthy men, a marked decrease in plasma PLP level was observed with increasing age, but EASAT-AC was not affected [71]. In a recent study by Löwik et al. moderate alcohol consumption was observed to lower EASAT-AC, whereas plasma PLP was not significantly influenced [78].

\section{Metabolic loading tests}

Assessment of biochemical vitamin B-6 status by the parameters discussed so far all depend on comparison with a "normal" range. Especially because there is no consensus about values representing adequate or deficient vitamin B-6 status, these methods must be considered arbitrary. Vitamin B-6 status assessment by means of a metabolic loading test determines the extent to which an individual subject is able to metabolize a test dose of a physiological substrate with a PLP-dependent metabolism. This would appear a more meaningful test of vitamin B-6 nutritional status, as it measures whether the individual's vitamin B-6 intake is adequate to meet his idiosyncratic metabolic requirement rather than whether intake is adequate to result in biochemical vitamin B-6 status parameters within a reference range.

Two amino acids, tryptophan and methionine, have been used in metabolic loading tests to assess vitamin B-6 nutritional status. For both amino acids there are PLP-dependent steps in major metabolic pathways. Vitamin B-6 deficiency gives rise to urinary excretion of metabolites in abnormal ratios. 


\section{Tryptophan load test}

Essentially, total dietary tryptophan intake is metabolized through the oxidative pathway illustrated in Fig. 2, with only minor amounts required for synthesis of the neurotransmitter 5-hydroxytryptamine and for protein synthesis. Besides total oxidation via acetyl-CoA, the oxidative pathway of tryptophan metabolism also provides a pathway for synthesis of nicotinamide adenine dinucleotides (NAD, NADP). Under normal conditions the enzyme tryptophan oxygenase (EC 1.13.11.11) is the rate-limiting enzyme in the pathway. The activity of succeeding enzymes is such that little accumulation of intermediates occurs. In vitamin B-6 deficiency the activity of kynureninase (EC 3.7.1.3), which is a PLPdependent enzyme, is lower than the activity of tryptophan oxygenase. As a result, there is a considerable accumulation of the intermediary metabolites kynurenine and hydroxykynurenine. This gives rise to increased metabolism via a normally minor route, yielding kynurenic acid and xanthurenic acid. Measuring urinary excretion of these compounds both before and after an oral tryptopan load (usually $2 \mathrm{~g}$ for an adult) gives an indication of nutritional vitamin B-6 status.

Abnomally increased excretion of tryptophan metabolites after a test dose of tryptophan is no conclusive evidence of vitamin B-6 deficiency, because various factors unrelated to vitamin B-6 affect tryptophan metabolism [52]. Hormonal

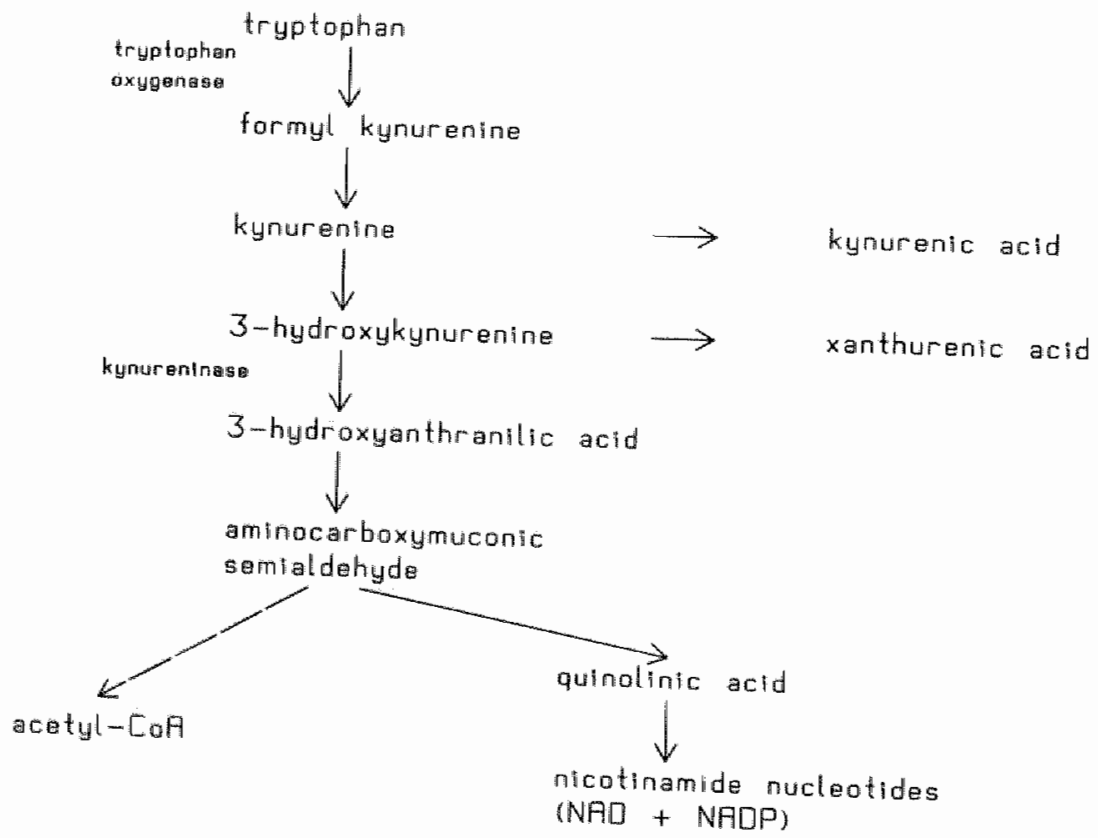

Fig. 2. Oxidative pathway of tryptophan metabolism. 
influence is such a possible interference. Tryptophan oxidase synthesis is induced by glucocorticoid hormones. High circulating glucocorticoid levels (as a result of stress or illness) may thus result in a metabolic flux through the tryptophan metabolism pathway saturating the capacity of kynureninase. Estrogen conjugates are direct competitive inhibitors of kynureninase. Both exogenous estrogens (e.g. oral contraceptive agents) and endogenous estrogens (e.g. in pregnancy) may give rise to accumulation of intermediary metabolites of tryptophan.

The tryptophan load test has not been used frequently in aging research, possibly because of the interfering factors discussed above. In some studies an abnormal urinary excretion pattern of tryptophan metabolites was observed more frequently at higher age $[79,80]$. In another study, men over 40 years of age excreted less tryptophan metabolites than younger men, with a change in the opposite direction for women in the same age groups [81]. When comparing pre- and postmenopausal women in yet another study no abnormal results of tryptophan load tests were observed in either age group [44].

Recently, attention was drawn to tryptophan because patients taking oral tryptophan-containing products developed a new syndrome, characterized by symptoms like eosinophilia, myalgia, arthralgia, breathlessness and pulmonary infiltrates (eosinophilia-myalgia syndrome, or EMS). Increasing numbers of reported cases both in the USA and in the EEC have led to withdrawal from the market of oral medicinal products containing tryptophan. In most cases in which the origin of the tryptophan could be identified, the starting material originated from one single Japanese manufacturer. In the tryptophan produced contaminants have been found, but a causal effect in humans has not been convincingly proven. Other mechanisms could be involved as well, because there is not sufficient evidence as yet to explain all cases of EMS reported [82]. In the meantime, performing tryptophan load tests should be advised against on medical-ethical grounds.

\section{Methionine load test}

Three enzymes involved in methionine metabolism (Fig. 3) are PLP-dependent: cystathionine synthase (EC 4.2.1.22), cystathionase (EC 4.4.1.1) and cysteine sulfinate decarboxylase (EC 4.1.1.29). Vitamin B-6 deficiency, both after a loading dose of methionine (usually $3 \mathrm{~g}$ for an adult) and under basal conditions, gives rise to an abnormal pattern of urinary metabolite excretion. Excretion of homocysteine (and of homocysteine metabolites, homocystine and mixed disulfides of homocysteine and cysteine), excretion of cystathionine and cysteine sulfinic acid is increased, whereas excretion of taurine is reduced $[83,84]$.

The methionine load test has not been used frequently in vitamin B-6 status assessment. This could be due to the fact that the analytical techniques involved are more complicated than those required for determination of urinary tryptophan metabolites. Unlike the situation for the tryptophan load test, however, no factors interfering with the interpretation of the methionine load test have been reported so 


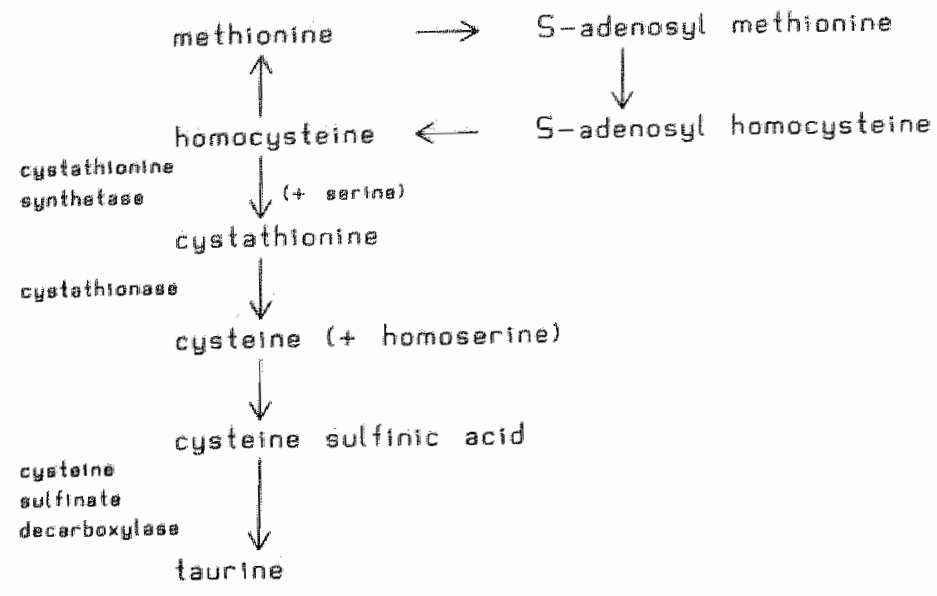

Fig. 3. Methionine metabolism.

far. This suggests the methionine load test could be more appropriate than the tryptophan load rest for the assessment of nutritional vitamin B-6 status, once analytical problems have been solved.

\section{Vitamin B-6 biokinetics and aging}

The observed lower plasma PLP concentration with increasing age could simply reflect the lower dietary vitamin B-6 intake generally observed in elderly people. However, another possible explanation of the lower circulatory PLP levels in the elderly could be age-related differences in vitamin B-6 biokinetics. Supplementation with doses of 2-20 mg PN per day is generally sufficient to obtain values for biochemical vitamin B-6 status parameters in the elderly within the younger adult reference range. However, in some studies $10-20 \%$ of the elderly were found not to respond to supplementation $[60,74]$. Furthermore, despite vitamin B-6 intakes not unlike those of a group of younger subjects, biochemical vitamin B-6 status parameter values indicative of deficient vitamin B-6 status were much more prevalent in elderly people than in young adults [62]. Biokinetic processes involved could be absorption, distribution, metabolism or excretion of vitamin B-6.

\section{Absorption}

Oral supplements of vitamin B-6 readily increase plasma PLP concentrations, in young adults as well as in elderly people. Therefore, absorption of vitamin B-6 is thought not to be affected by aging [85]. However, absorption of pyridoxine. $\mathrm{HCl}$ 
from oral supplements may not be comparable to absorption of vitamin B-6 vitamers from foods.

Especially absorption of protein-bound phosphorylated vitamers could well be compromised at old age. The phosphorylated vitamers present in foods of animal origin (mostly PLP and PMP) are to be hydrolyzed first, by intestinal alkaline phosphatase, to their corresponding nonphosphorylated forms, which are readily absorbed through passive diffusion [15-20]. Intraluminal hydrolysis of PLP is inhibited by the presence of protein or its digestive products (peptides, amino acids), probably through Schiff base binding [86]. Protein interference with intraluminal PLP hydrolysis can be prevented at lower intraluminal $\mathrm{pH}$. However, at higher age achlorhydria becomes more prevalent (not to mention the higher use of gastric-acidlowering drug therapies). Theoretically, higher postprandial gastric and upper small intestinal $\mathrm{pH}$ may lower PLP absorption. On the other hand, severe atrophic gastritis in elderly people was not observed to impair vitamin B-6 status [87].

\section{Distribution}

Aging is associated with a progressive accumulation of adipose tissue to the expense of lean body mass [7, 8]. The distribution of water-soluble vitamin B-6 vitamers could well be influenced by this change in body composition. A decrease in lean body mass would be expected to increase concentration of water-soluble compounds, whereas aging is generally associated with a decrease in plasma PLP level

$[62,65,70-72,76,79]$. Muscle is considered to be the main vitamin B-6 depository [39]. An age-related decrease in total muscle mass could therefore represent a decrease in total body vitamin B-6 store.

Protein binding of PLP is one of the mechanisms regulating the vitamin B-6 content of liver and probably of other organs (and plasma) as well [32-36]. Protein binding protects PLP against hydrolysis by alkaline phosphatase. Age-related changes in protein-binding capacity of plasma and/or organ tissues might contribute to the lower plasma PLP levels observed in elderly people. An age-related decrease in plasma albumin level has been observed [91, 92]. However, this decrease is small, and the PLP-binding capacity of albumin is very large [35]. Therefore, a decreasing plasma albumin concentration with higher age probably has only a minor influence on circulating PLP levels. On the other hand, liver release of albumin-bound PLP might well decrease with age.

\section{Metabolism}

Animal and human studies have presented some evidence for age-related changes in vitamin B-6 metabolism. Fonda et al. observed increased PN uptake into the livers of senescent mice compared to young adult controls [88]. Increased hydrolysis of PLP: was suggested to occur in the brains of these senescent mice [89]. Blood concentrations of PL and 4-PA were higher in old than in young adult mice [90]. 
A difference in response of plasma PLP concentration and urinary 4-PA excretion was reponted between young and middle-aged women under conditions of controlled dietary intake of vitamin B-6 [44]. Intestinal absorption of the subjects studied had been assessed with a xylose test, as to exclude possible interference from malabsorption of the vitamin as much as possible. However, when studying the effect of age on indices of vitamin B-6 metabolism in men, no differences between age groups in response of plasma and erythrocyte PLP concentrations and excretion of 4-PA was observed after an oral $\mathrm{PN}$. $\mathrm{HCl}$ dose [46]. In this study, a significant negative correlation was found between baseline plasma PLP levels (highest in the young adult age group) and serum alkaline phosphatase activity. With increasing age serum alkaline phosphatase activity usually increases [93]. The observed age-related increase in serum alkaline phosphatase activity is assumed to contribute to the decrease in plasma PLP concentration.

\section{Excretion}

In urine, the predominant vitamin B-6 compound excreted is 4-PA. With physiological vitamin B-6 intakes (i.e. either through the diet alone or through vitamin B-6 supplements or oral doses comparable to the vitamin B-6 RDA) active vitamin B-6 vitamers are present in urine in much lower amounts than 4-PA [see e.g. 461. Urinary excretion of vitamin B-6 ingested seems to be dependent on (rate of) 4-PA formation rather than on renal excretion of active vitamin B-6 vitamers. The ratio between 4-PA and active vitamin B-6 vitamers present in urine before and after an oral $\mathrm{PN} . \mathrm{HCl}$ dose was observed not to be affected by age [46].

\section{Vitamin B-6 requirement of the elderly}

\section{Vitamin B-6 Recommended Dietary Allowance (RDA)}

Recommended Dietary Allowances (RDAs) are established to meet the nutritional needs of healthy population groups. Considerations of how diseases or drugs might alter nutritional requirements are not included. In this review neither disease nor drug effects are addressed, either. For vitamins, adults are classified into two age categories in the 1980 RDA: 23-50 years and 51 years and over [57]. Vitamin B-6 RDA is similar for both adult age categories $(20 \mu \mathrm{g} / \mathrm{g}$ protein or $2.2 \mathrm{mg} / \mathrm{day}$ for men and $2.0 \mathrm{mg} /$ day for women). In the 1990 edition, adult age groups are 25-50 and $51+$; vitamin B 6 RDA is $16 \mu \mathrm{g} / \mathrm{g}$ protein for men and women in both age categories [158]. Adults 23 or 25 years and over cannot be regarded as to form a homogeneous group. Using $51+$ as a homogeneous age category is increasingly recognized as being inappropriate. Furthermore, the implicit goal of setting criteria for RDAs has, at present, not clearly been defined. Should nutritional requirements be adjusted according to possibly detrimental age-dependent changes (such as changes in body 
composition, activity), or should nutrient RDAs be set to achieve optimum functioning for different age groups?

Evidence has been presented from human and animal studies that vitamin B-6 metabolism changes with age. Whether these age-related changes in vitamin B-6 metabolism influence vitamin B-6 requirement remains to be established.

\section{Conclusions}

Aging is associated with an increased prevalence of vitamin B-6 status parameters indicative of a low nutritional vitamin B-6 status in younger adults. Whether these age-related status parameter changes represent changes in functional vitamin B-6 status remains to be established. Independent criteria of functional (subclinical) vitamin B-6 deficiency are not available yet. Little is known about the functional consequences of a long-term (marginally) inadequate vitamin B-6 status.

One could propose to increase vitamin B-6 RDA for the elderly as to result in vitamin B-6 status parameter values within the range observed in younger adults. However, prospective studies on the correlation between vitamin B-6 status parameter improvement (through increased dietary and/or supplemental intake) on the one hand and morbidity, mortality and occurrence of functional deficits on the other, thave not been performed. Before changing the vitamin B-6 RDA for elderly people, more research into the relationship between vitamin B-6 status parameters and health or disease, or, in other words, functional criteria of vitamin B- 6 nutritional status, is needed.

\section{References}

1. Hollander CF, Becker HA. Growing old in the future. Scenarios on health and ageing 19842000. Scenario-report. commissioned by the steering committee on future health scenarios. Dordrecht. Netherlands: Martinus Nijhoff, 1987: 222-3.

2. Rothstein $\mathrm{M}$. Biochemical studies of aging. Fitting more pieces into a far-from-finished mosaic. Chem Engng News, 1986:August 11:26-39.

3. Brouwer A. The nature of ageing. In: Horan MA, Brouwer A, Eds. Gerontology: approaches to clinical and biomedical research. London: Edward Arnold (in press).

4. Makinodian T, Good RA, Kay MMB. Immunology and aging. In: Makinodian T, Yunis EJ, Eds. Comprehensive immunology, Vol. 1. New York: Plenum Press, 1977" 9-22.

5. Young EA. Evidence relating selected vitamins and minerals to health and disease in the elderly population in the United States: introduction. Am J Clin Nutr 1982:36:979-85.

6. Lowik MRH, Kok FJ. Schaafsma G. Ockhuizen T. Woeding en verouderingsprocessen Implicaties woor bevolkingsonderzoek. Tijdschr Soc Gezondheidsz 1989,67:375-8.

7. Shock NW. Age changes in some physiologic processes. Geriatrics 1957;12:40-8.

8. Munro HN Nutrition-related problems of niddle age. Proc Nutr Soc 1984:43:281-8.

9. Chen LH. Liu S, Cook Newell ME, Barnes K. Surwey of drug use by the elderly and possible impact of drugs on nutritional status. Drug Nutr Interact 1985:3: 73-86.

10. Prinsley DM. Management of nutritional problems in the elderly. In: Wahlquist ML, Truswell AS. Eds. Recent adwances in clinical nutrition, Vol. 2. London: John Libbey, 1986: 199-202.

11. Löwik MRH, Meulmeester JF. Westenbrink S. Komt ouderdom met voedingsgebreken? Literatuuronderzoek nat voeding(stoestand) en veroudering. Ned Tijdschr Diëtisten 1987:42: $218-21$. 
12. Gregory III JF. Ink SL. Identhication and quantification of pyridoxine-Buglucoside as a major form of vilamin B-6 in plant-derived foods. I Agric Food Chem 1987,35: 76-82.

13. Gregory II JF, Ink SL, Sartain DB. Degradation and binding to food proteins of vitamin B-6 compounds during thermal processing. J Food Sci 1986:51: 1345-51.

14. Middleton $111 \mathrm{HM}$. In vivo absorption and phosphorylation of pyridoxine $\mathrm{HCl}$ in rat jejunum. Gastroenterology 1979; $76: 43-9$.

15. Middleton III HM. Intestinal absorption of pyridoxal-5'-phosphate: disappearance from perfused segments of rat jejunum in wivo. J Nurr 1979:109:975-81.

16. Mehanso H, Hamm MW, Henderson L.VM. Transpont and metabolism of pyridoxal and pyridoxal phosphate in the small intestine of the rat. J Nutr 1979:109:1542-51.

17. Hamm MW, Mehanso H, Henderson L-VM. Transport and melabolism of pyridoxamine and Pyridoxamine phosphate in the small intestine of the rat. J Nutr 1979;109:1552-9.

18. Middleton III HM. Characterization of pyridoxal 5 -phosphate disappearance from in vivo perfused segments of rat jejumum. INutr 1982;112:269-75.

19. Middleton IH HM. Intestinal hydrolysis of pyridoxal $5^{\circ}$-phosphate in vitro and in vivo in the rat. Effect of protein binding and $\mathrm{pH}$. Gastroenterology 1986;91: 343-50.

20. Middlieton III HM. Transmural absorption of pyridoxine. HCl in witro in the rat jejunum. Proc Soc Exp Biol Med 9181;167: 519-24.

21. Trumbo PR, Gregory III JF, Sartain DB. Incomplete utilization of pyridoxine-b-glucoside as vitamin B-6 in the rat. J Nutr 1988;118: 170-5.

22. Trumbo PR, Gregory III JF. Metabolic utilization of pyridoxine-B-glucoside in rats: influence of vitamin B-6 status and route of administration. J Nutr 1988:118:1336-42.

23. Gregory JF, Trumbo PR, Bailey LB, Toth JP, Baumgartner TG, Cerda JJ. Bioavailability of pyridoxine-5"-beta-D-glucoside determined in humans by stable-isotope methods. J Nutr $1991 ; 121: 177-86$.

24. Tarr JB, Tamura T, Stokstad ELR. Avallability of vitamin B-6 and pantothenate in an average American diet in man. Am J Clin Nutr 1981;34:1328.37.

25. Nguyen LB, Gregory III JF, Damron BL. Effects of selected polysaccharides on the bioavailability of pyridoxine in rats and chicks. J Nutr 1981:111: 1403-10.

26. Hudson CA, Betschart AA, Oace SM. Bioavailability of vitamin B-6 from rat diets containing wheat bran or cellulose. J Nutr 1988:118: 65-71.

27. Coburn SP. Mahuren JD, Wostmann BS. Snyder DL, Townsend DW. Role of intesitinal microflora in the metabolism of vitamin B-6 and 4 "-deoxypyridoxime examined using germfree guinea pigs and rats. J Nutr 1989;119:181-8.

28. Leklem JE. Miller LT, Perera AD, Peffers DE. Bioavailability of vitamin B-6 from wheat bread in humans. I Nutr 1980;110: 1819-28.

29. Shultz TD, Leklem JE. Vitamin B-6 status and bioavallability in vegetarian women. Am J Clin Nutr 1987;46: 647-51.

30. Löwik MRH. Schrijwer J, Berg H wan den, Hulshof KFAM, Wedel M, Ockhuizen T. Effect of dietary fiber on the vitamin B-6 status among vegetarian and nonvegetarian elderly (Dutch Nutrition Surveillance System). J Am Coll Nutr 1990;9:241-9.

31. Nguyen LB, Gregory III JF. Burgin CW, Cerda JJ. In witro binding of vitamin B-6 by selected polysaccharides, lignin, and wheat bran. J Food Sci 1981:46:1860-2.

32. Lumeng $L$. Li T-K. Mammalian vitamin B-6 metabolism: regulatory role of protein-binding and the hydrolysis of pyridoxal 5 -phosphate in storage and transport. In: Tryfiates GP, Ed. Vitamin B-6 metabolism and role in growth. Westport. CT: Food \& Nutrition Press, 19:80: 27-52.

33. Merrill AH, Henderson JM, Wang E. McDonatd BW, Millikan WJ. Metabolism of vitamin B-6 by human liver. J Nutr 1984:114: 1664-74.

34. Anderson BB, Newmark PA, Rawlins M, Green R. Plasma binding of vitamin B 45 compounds. Nature 1974:250:502-4.

35. Lumeng L. Brashear RE, Li T-K. Pyridoxal-S'-phosphate in plasma: source, protein-binding and cellula" Iransport. J Lab Clin Med 1974:84: 334-43.

36. Lumeng L, LiT-K, Lui A. The interorgan transport and metabolism of vitamin B-6. In: Reynolds RD. JE Leklem, Eds. Vitamin B-6: Its role in health and disease. New York: Alan R, Liss, 1985: $35-54$. 
37. Lumeng L. Schenker S. Li T-K. Brashear RE. Compton MC. Clearance and nuabolism of plasma pyridoxal $5^{\circ}$-phosphate in the dog. J Lab Clin Med 1984;103, 5969.

38. Whyte MP, Mahuren JD. Fedde KN, Cole FS. McCabe ERB, Coburn SP. Pernatal hypophosphatasia: tissue levels of viamin B-6 are unremarkable despite natkedly increasing circulating concentrations of pyridoxat-5'-phosphate. J Clin Invest 1988:81: 1234-9.

39. Krebs EG. Fischer EH. Phosphorylase and related enzymes of glycogen metabolism. Vitamins Hormones 1964:22:399-410.

40. Black Al. Guirard BM, Snell EE. The behavior of muscte phosphorylase as a reserwoir for vitamin B-6 in the rat. J Nutr 1978:108:670-7.

41. Leklem JE, Shultz TD. Increased plasma pyridoxal 5 phosphate and vitamin B-6 in male adolescents after a 4500-meter run. Am J Chin Nutr 1983:38:541.8.

42. Manore MM, Leklem JE, Watter MC. Vitamin B 6 metabolism as affected by exercise in trained and untrained women fed diets differing in carbohydrate and witamin B-6 content. Am J Clin Nutr 1987;46: 995-1004.

43. Hofmann A. Reynolds RD, Smoak BL, Villanueva VG. Deuster PA. Plasma pyridoxal and pyridoxal-5'-phosphate concentrations in response to ingestion of water or glucose polymer during a 2 -h run. Am J Clin Nutr 1991:53:84-9.

44. Lee CM. Leklem JE. Differences in vitamin B-6 status indicator responses between young and middle-aged women fed constant diets with two levels of vitamin B-6. Am J Clin Nutr 1985:42: $226-34$

45. Simon I, Leinert J, Hötzel D. Methoden und deren Wertung zur Bestinmung des Vitaminen-B-6Versorgungszustandes beim Menschen. 4. Mitteillung. 4-PA: Die Aussagefahigheit des Parameters. Int J Vit Nutr Res 1982;52:287-97.

46. Kant AK, Moser-Veillon PB, Reynolds RD. Effect of age on changes in plasma "erythrocyle, and urinary B-6 vitamers after an oral vitamin B-6 load. Am J Clin Nutr 1988:48: 1284-90.

47. Lui A, Lumeng L. Li T-K. Biliary excretion of 14 C-labeled vitamin B-6 in ats. INutr 1983:113; 893-8.

48. Bender DA. The role of vitamin B-6 in amino acid metabolism. In: Amino acid metabolism, 2nd ed. Chichester: John Wiley, 1985: 75-94.

49. Cori CF, Illingsworth B. The prosthetic group of phosphorylase. Proc Natl Acad Sci USA 1957:43: $547-52$.

50. Helmreich EJM. Klein HW. The role of pyridoxal phosphate in the catalysis of glycogen phosphorylase. Angew Chem 1980;19:441-55.

51. Takagi M, Fukui T, Shimomura S. Catalytic mechanism of glycogen phosphorylase: pyridoxal( $5^{\prime \prime}$ diphospho(1)- $\alpha$-D-glucose as a transition state analoguc. Proc Nau Acad Sci LSA $1982 ; 79: 3716-9$.

52. Bender DA. Oestrogens and vitamin B-6 - actions and interactions. Whd Rev Nutr Diet 1987:51: 140-88.

53. Bender DA, Bowden J.F, Coulson WF. Dewji MR. Sutton J, Symes EK. Vitamin B-6 deficiency enthances end-organ sensitivity to steroid hormones. In: Leklem dE, Reynolds RD, Edls. Clinical and physiological applications of vilamin B-6. New York: Alan $\mathbb{R}$. Liss, 1988: 45-9.

54. Ebadi $M$. Vitamin B-6 and biogenic amines in brain metabolism. In: Human vitamin B-6 requirements. National research Council, Commiltee on Dietary Allowances. Wasthington DC. National Academy or Sciences 1978: 129.61.

55. Merrill $\mathbb{I r}$. AH. Henderson JM. Diseases associated with delects in witamin B-6 metalolism or utilization. Annu Rev Nutr 1987:7:137.56.

56. Anonymous. Dietary protein and vitamin B6 requirements. Nutr Rev 1987:45: 23-5.

57. Food and Nutrition Board. Recommended Dietary Allowances, 9th ed. Washington DC: National Academy of Sciences 1980.

58. Food and Nutrition Board. Recommended Dietary Allowances. 10th ed. Wrashington DC: National Academy of Sciences 1989.

59. Vir SC. Love AHG. Vitamin B.6 status of the hospitalized aged. Am J Clin Nutr 1978:31: 1383m 91.

60. Vir SC. Love AHG. Nutritional status of institutionalized and noninstitutionalized aged in Betfast. Northern Ireland. Am J Clin Nutr 1979;32: 1934-47. 
61. Garry PJ, Goodwin IS. Hun WC, Hooper EM, Leonard AG. Nutritonal status in a healthy thderly population. diefary and supplemental intakes. Arn J Clin Nutr 1982;36: 319-31.

62. Guilland $\mathbb{H C}_{\mathrm{C}} \mathrm{Bereks}$-Reguig $\mathrm{B}$, Lequeu B. Moreau D. Klepping J, Richard D. Evaluation of pyridoxine intake and pyridoxine status among aged institutionalised people. In J Vit Nutr Res $1984: 54: 185-93$.

63. McGandy RB, Russell RM, Hart SC, Jacob RA, Tannenbaum S, Peters H. Sahyoun N, Oradovec CL. Nurrionat status survey of healthy noninstitutionalized elderly: energy and nutrient inakes from theeway diel reconds and nutrent supplements. Nutr Res 1986:6:785-98.

64. Lowik MRH, Westenbrink S. Hulshof KFAM, Kistemaker C, Hermus RJJ. Nutrition and aging: dietary intake of "apparenty healthy' elderly (Dutch Nutrition Surveillance Systern). J Am Coll Nutr 1989:8:347-56.

65. Manore MM, Vaughan LA, Carroll SS, Leklem JE. Plasma pyridoxal-5"-phosphate concentration and dietary vitamin B-6 inlake in free-living elderly people. Am J Clin Nutr $1989.50: 339-45$

66. Kant AK Block G. Dietary vitamin B-6 intake and food sources in the US population: NHANES 11. 1976-1980. Am d Clin Mutr 1990:52:707-16.

67. Lumeng L. Ryan MP, LIT T.K. Validation and diagnosic valte of plasma pyridoxal 5 'phosphate medsurements in vitamin B-6 nutrition of the rat. I Nutr 1978;108:545 53.

68. Leklem JE, Hollenbeck CB. Acute ingestion of glucose decreases plasma pyridoxal-5"phosphate and tolat vilamin B-6 concentration. Am J Clin Nutr 1990:51:832-6.

69. Coburn SP. White MP. Role of phosphatase in the regulation of vitamin B-6 metabolism in hypophosphatasia and other disorders. In: Leklem JE, Reynolds RD. Eds. Clinical and physiological applications of vitamin B-6. Curren Topics in Nutrition and Disease. Vol, 19. New York: Alan R. Liss, 1988: 65.93.

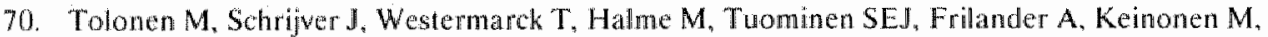
Sarna S. Vitamin B-6 status of Finnish elderly. Comparison with Dutch younger adults and elderly. The offect of supplementation. Int J Vit Nutr Res 1988:58: 73-7.

71. Rose CS. György P, Butler M, Andres R, Norris AH. Shock NW, Tobin J, Brin M. Spiegel H. Age differences in vilamin B-6 stams of 617 men. Am J Clin Nutr 1976:29:847-53.

72. Low ${ }^{2}$ MRH, Berg H wan den, Westenbrink S, Wedel M, Schrijper J, Ockhuizen Th. Doseresponse relationships regarding vitamin $B-6$ in elderly people; a nationwide nutritional survey (Duich Nutritional Surveillance System). Am J Clin Nutr 1989:50: 391 -9.

73. Woo J. Ho SC. MacDonald D, Swaminathan R. Vitamin nutritional status in elderly Chinese living in chronic care institutions. Nutr Res 1989:9: 1071-80.

74. Hoorn RKJ, Flikweert JP, Westerink D. Vitamin B-1, B-2 and B-6 deficiencies in geriatric patients, measured by coenzyme stimulation of enzyme activities. Clin Chim Acta 1975;61:15162.

75. Porrini $M_{4}$ Testolin G, Simonetli P. Moneta A, Rovati P. Aguzai F. Nutritional status of non institutionalized elderly people in North Itally. Internat J Vit Nutr Res 1987;57: 203-16.

76. Hamfelt A, Söderhjelm L. Vitamin B-6 and aging. In: Leklem JE, Reynolds RD. Eds. Clinical and physiological applications of vitamin B-6. Current Topics in Nutrition and Disease, Vol. 19. New York: Alan R. Liss, 1988: 95-107.

77. Lut A, Lumeng L, Aronolf GR, Li T-K. Relationship between body store of vitamin B-6 and plasma pyridoxal-P clearance: metabolic balance sludies in humans. J Lab Clin Med 1985:106: $491-7$.

78. Löwik MRH, Poppel G van. Wedel M, Berg H van den, Schrijuer J. Dependence of vitamin B-6 status assessement on alcohol intake among elderly men and women (Dutch Nutritional Surveillance System) J Nutr 1991;120:1344-51.

79. Hamfelt A. Age variation of vitamin B-6 metabolism in man. Clin Chim Acta 1964:10:48-54.

80. Ranke E, Tauber SA, Horonick A. Ranke B, Goodhart RS, Chow BF. Vitamin B-6 deficiency in the aged. $J$ Gerontol 1960:15;41 4 .

81. Leklem JE. Quantitative aspects of tryptophan metabolism in humans and other species: a peview. Am J Clin Nutr 1971:24:659-72.

82. Committee for Proprictary Medicinal Products (CPMP), Commision of the European Communities, Directonate for Internal Market and Industrial Affairs. Position statement on Atryptophan. Brussels. December 12, 1990. 
83. Sturman JA. Vitamin B-6 and sulfur amino acid metabolism. In: Leklem JE, Reynolds RD. Eds. Methods in vitamin B-6 nutrution: analysis and status assessment. New York: Plenum Press 1981: 341.73.

84. Linkswiler HM. Methonine metabolism excretion as affected by a witamin B-6 deficiency. In: Jeklem JE, Reynolds RD. Eds. Methods in vitamin B-6 nutrition: analysis and status assessment. New York: Plenum Press, 1981: 373-82.

85. Gregory III JF, Kirk JR. The bioavailability of vitamin B-6 in foods. Nutr Rev 1981;39:1-8.

86. Middleton III HM. Intestinal hydrolysis of pyridoxal-5'-phosphate in vitro and in wivo in the rat. Effects of amino acids and oligopeptides. Digest Dis Sci 1990:35: 113-20.

87. Ribaya-Mercado JD, Otradovec CL, Russell RM, Samloff IM. Atrophic gast ritis does nor impair vitamin B-6 status in the elderly. Gastroenterology $1987.93: 222-3$.

88. Fonda ML. Eggers DK, Mehta R. Vitamin B-6 metabolism in the livers of young adulli and senescent mice. Exp Gerontol 1980;15:457-63.

89. Fonda ML, Eggers DK, Auerbach S, Fritsch L. Vitamin B-6 metabolism in the brains of young adult and senescent mice. Exp Gerontol 1980;15: 473-9.

90. Fonda ML, Eggers DK. Vitamin B-6 metabolism in the blood of young adult and senescent mice. Exp Gerontol 1980:15: 465 72.

91. Mitchell CO, Lipschitz DA. The effect of age and sex on the routinely used measurements to assess the nutritional status of hospitalized patients. Am J Clin Nutr 1982;36:340-9.

92. Pacifici GM, Viani A, Taddeucci-Brunelli G, Rizzo G. Carrai M. Schulz H-U. Effects of development, aging, and renal and hepatic insufficiency as well ats hemodialysis on the piasma concentration of albumin and $\alpha 1$-acid glycoprotein: implications for binding of drug. Therapeutic Drug Monitoring 1986;8: 259-63.

93. Keating R. Jones J, Elveback $L$, Randall $R$. The relation of age and sex to distribution of values in healthy adults of serum calcium, inorganic phosphorus, magnesium, alkaline phosphatase. total protein, albumin, and blood urea. J Lab Clin Med 1969:73: 825-34. 


\title{
The biokinetic approach in nutrition research
}

\begin{abstract}
Biokinetics is defined, its history described and basic principles of experimental design and data handling in biokinetic research are elucidated. Examples are presented to show the possible advantages of the biokinetic approach over the traditional biochemical approach in nutrient research. The biokinetic approach should not replace the biochemical approach: biokinetic and biochemical experiments are to be performed both. Results of biokinetic studies complement results of biochemical studies, and vice versa, thus offering a possibility to greatly enhance present knowledge on nutrition.
\end{abstract}

\section{Introduction}

Numerous studies on nutrition and the function and metabolism of nutrients have been performed, and the body of knowledge on the subject is still increasing. Objectives of nutritional research can be clasified into two distinct but intertwined fields: procurement of knowledge of the physiological function of the nutrient of interest on the one hand, and determination of nutrient requirements on the other. Physiological functions of nutrients appear to be wel" established, although every now and then new functions are discovered. Furthermore, there seems to be wide agreement as to what nutrients are indispensible. However, requirements for indispensible nutrients, especially micronutrients, are continuously reassessed.

Recently, the 10th edition of Recommended Dietary Allowances (RDAs) was published by the US National Academy of Sciences [1]. The RDAs, expressed as average daily intake, are intended to allow for individual variation in nutrient requirements among healthy persons of different age and sex categories. Even the current 10 th edition is not considered to definitely set RDAs for times to come. The future 11 th edition is expected to address, more elaborately than the 10 th edition, the possibly specific nutritional requirements of the elderly population. [2]. 
Until now nutrition research has generated mainly descriptive, qualitative statements. Due to the approach generally used, data gathered are largely static in nature. A literature search on, for example, vitamin B-6 and aging reveals mainly epidemiologic and biochemical studies. Observations indicate that (dietary) vitamin B-6 intake is generally low in elderly people [3-8]. The plasma pyridoxal-5'phosphate (PLP) concentration, a widely used biochemical parameter of vitamin B-6 status, is observed to be lower with increasing age [6, 9-14]. This lower plasma PLP level at higher age could simply reflect a low dietary vitamin B-6 intake. However, the biochemical vitamin B-6 status of elderly people does not always respond to oral vitamin B-6 supplementation [4, 15]. Animal and human studies have presented some evidence for an age-related change in vitamin B-6 metabolism [16-19].

Two questions should be answered before measures are taken to promote an increase vitamin B-6 intake among elderly people (for example, via a raise of the vitamin B-6 RDA) to move vitamin B-6 status parameter values within the range observed in younger adults. First, does the fate of vitamin B-6 after consumption differ indeed between elderly people and younger adults? Second, does the lower biochemical vitamin B-6 status generally observed in the elderly reflect a functional impairment of vitamin B-6 nutriture? To answer the second question prospective studies (intervention trials) on correlation between biochemical vitamin B-6 status and morbidity, mortality and prevalence of functional deficits should be started. To answer the first question, the dynamic behavior of vitamin B-6 (i.e. how does the human body handle vitamin B-6) should be studied. The purpose of this report is to explain how a biokinetic approach in nutrition research can provide more insight in and new information on systems of this type, dynamic instead of static, than the epidemiologic and biochemical studies performed so far.

\section{Definition and history of (bio)kinetics}

Kinctics is used to describe the interrelation, in time and space, of a substance and a system. The mathematics underlying the kinetic approach have originally been developed for use in chemistry, to enable scientists, but also chemical plant operators, to control, simulate or predict the outcome of a certain (chemical) reaction under specified conditions. In the 1960s application of this theory on control of chemical reaction vessels to physiological systems became more and more accepted [20!. A new field of science emerged: the field of pharmacokinetics [21].

Before pharmacokinetic knowledge became established, safe and effective dose regimens of drugs were found by trial and error. If response to a drug administered was absent or weak, the dose was increased. If signs of toxicity were noted, the dose was lowered. If the desirable effect of the drug declined rapidly after dosing, either the dose was increased or, if higher doses were expected to evoke side-effects, the same (low) dose was administered at shorter intervals. This empirical approach was 
to be used for every, new drug available, which involved experiments with different dose regimens on a large number of patients, with several dosage regimens proving to be ineffective or inducing excessively toxic reactions. Although the mechanisms of drug absorption, distribution and elimination were known, no knowledge on the kinetics of these processes, nor means to describe their kinetics, were available. Pharmacokinetics describes the relation between dose size, frequency of dosing and route of administration on the one hand, and drug level changes in time in the body on the other. In this way pharmacokinetics enables medical practitioners to prescribe a therapeutically effective and safe drug treatment.

A similar approach as described for pharmacokinetics can be used for any substance entering the human (or animal) body. Pharmacokinetics is rapidly gaining importance in understanding the implications of intake of other potentially toxic substances, such as food additives and air pollutants. Scientists working on this type of xenobiotics prefer the name toxicakinetics, to distinguish themselves from those doing kinetic research on drugs.

In the early days of pharmacokinetics it was already recognized that the kinetic approach to drug disposition in the (human) body could be equally well applied to nutrients [21]. In an introductory lecture Kübler proposed to use the term biokinetics when applying pharmacokinetic techniques to nutrient research [22]. There is, however, one important difference between pharmacokinetics and toxicokinetics on the one hand and biokinetics on the other. The usual goal of pharmacokinetics and toxicokinetics is to calculate the concentration of the substance of interest reached in various body parts and to calculate the speed of its disposal. Of major importance in biokinetics is to estimate the extent of nutrient absorption (after ingestion), to assess the nutrient retention time in the body, and to calculate the size of the nutrient body store [23].

\section{Theoretical background of biokinetic modeling}

In biokinetics the system of interest, the human or animal body, is considered to be made up of one or more compartments. A compartment is a mathematical construction that may or may not define a discrete physiological or biochemical space. In each compartment the substance of interest is present at one level only (well mixed or homogeneous). Turnover of the substance from the compartment occurs at a slower rate than mixing within the compartment. For some substances, plasma is a distinct kinetic compartment. However if, for example, a substance mixes equally fast with total body water as with plasma, then total body water, not plasma, forms one compartment. One organ, or a set of organs, may act as a compartment, for example (part of) all striated muscle. On the other hand, within one organ more than one kinetically distinguishable compartment may be present, for example substances present in cytosol on the one hand and in microsomes on the other. Finally, compartments may have no physiological identity whatsoever. A typical 
example is diwision of the body into a compartment in rapid equilibrium with plasma on the one hand and a compartment in slow equilibrium with plasma on the other.

Two different study types can be distinguished in biokinetic research: dose studies and tracer studies. In dose studies one or more doses are administered and handling of the administered doses by the body is assessed by construction of concentration-time curves of the substance administered. Essentially this is the approach used in all pharmacokinetic and toxicokinetic research. When using this approach in nutrient research one must keep in mind that the dose(s) administered might perturb the biokinetic system under investigation. If, for example, vitamin $C$ is dosed at ten times the RDA, the renal threshold is exceeded and a major part of the vitamin $\mathrm{C}$ administered is excreted unchanged into urine [24]. Vitamin $\mathrm{C}$ up to a dose of $100 \mathrm{mg}$ (roughly the RDA), on the other hand, is metabolized prior to urinary excretion. In nutrient research tracer studies can render useful information without perturbating of the system of interest. In tracer studies a small amount of the substance of interest labeled with radioactive or stable isotopes is administered and dilution of the tracer in the body compartments is followed over time. The underlying presumption is that the labeled substance is handled exactly the same way as the unlabeled form studied.

After data collection two different approaches can be used to describe the underlying compartmental model: the mathematical approach and the physiological approach. In the mathematical approach, data usually consist of plasma or blood concentrations measured at specific time points after dosing. These data are fit to an exponential equation of the form

$$
\left.c(t)=\Sigma_{i}^{n}=1 \mid A_{i} \cdot \exp \left(\lambda_{i} \cdot t\right)\right]
$$

with $c(t)$ being the concentration at time $t$ after dosing, $A_{i}$ being the exponential constants, $\lambda_{i}$ being the exponential coefficients and $n$ being the number of compartments. An exponential equation is used because it usually describes the behavior of substances in biological systems adequately. For practical and statistical reasons, the maximum number of compartments to be determined by a mathematical model is usually three to four. A satisfactory fit to the data by varying $\mathrm{n}$, or possibly by introducing a nonexponential function, is no guarantee that the system studied is completely described by the model applied, but only that it is compatible with the hypothesized model. The exponential constants and exponential coefficients derived through data fitting are used to calculate the biokinetic parameters of interest. The mathematical approach is used to calculate parameters such as bioavailability, volume of distribution, mean residence time, total body clearance and total body pool. Typically, the compartments in the model have no physiological identity. An example of a mathematical compartmental model is given in Fig. 1.

Contrary to the mathematical approach, the physiological approach in compartmental modeling departs from body parts (for example, body tissues) with independently verified anatomical significance, on which information is obtained 


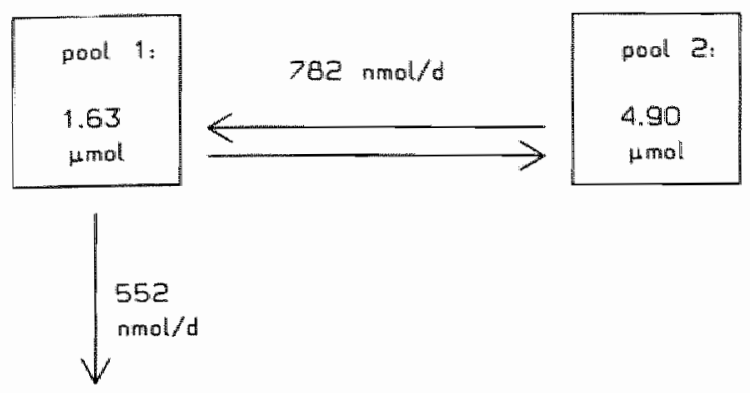

$\mathrm{SA}(\mathrm{t})=3.60 \cdot \exp (-0.921 \cdot \mathrm{t})+0.478 \cdot \exp (-0.0590 \cdot \mathrm{t})$

(SA in dpon/pmol, $t$ in days)

Fig. 1. Mathematical biokinetic model of vitamin B-6 in the rat derived from urinary specific activity (SA) data. Input is presumed to occur into the smaller compartment only [adapted from 25].

through literature searches. The physiological compartmental model contains, besides the identified compartments, also the structure of connections and estimates of fractional transfer coefficients between compartments. Compartmental models obtained through the physiological approach are usually more complex than those obtained through the mathematical approach (see Fig. 2). Also more powerful computational devices are required to provide numerical solutions for all equations describing a multicompartmental system. The study design generally involves more than serial sampling of blood or plasma: urine, feces and organ tissue concentrations are usually (but not necessarily) followed over time as well. Because (seriall) organ or tissue sampling is not always feasible in humans physiological compartmental models are usually developed through animal experiments. Physiologicall compartmental models are useful in estimating or illustrating the relative significance of various body parts in overall body handling of the substance of interest.

Ideally, after formulating (and testing) of a compartmental model, it should be verified independently. In nutrient research biochemical tests probably are best suited to verify predictions made via biokinetic modeling.

\section{Biokinetic parameters versus biochemical parameters: Examples}

\section{Plasma pyridoxal-5'-phosphate}

Plasma level of the metabolically active vitamin B-6 vitamer PLP is widely accepted to be fairly indicative of vitamin B-6 nutritional status. Plasma PLP level in man decreases with increasing age. Alkaline phosphatase (AP; EC 3.1.3.1), an enzyme present in serum, dephosphorylates substrate PLP to pyridoxal (PL). With increasing 


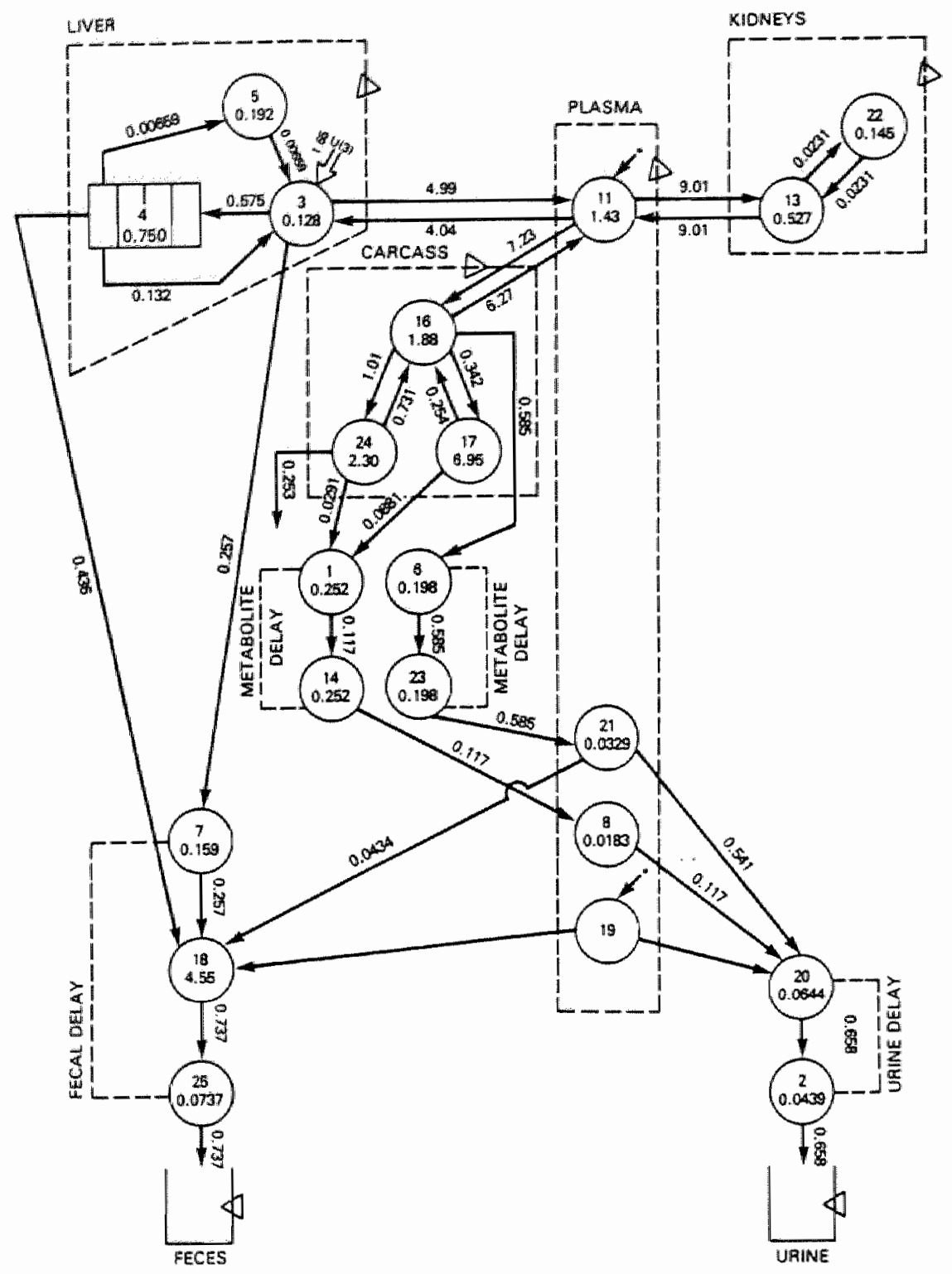

Fig. 2. Physiological biokinetic model for vitamin $A$ turnover in rats with low vitamin A status. Comparments are represented by numbered circles, small triangles are sites of sampling. Numbers between compartments are turnover or transfer rats. Compartment masses are shown withm compartments. The asterix denotes site of injection (donor plasma containing ${ }^{3}$ H-labeled retinol bound to retinol-binding protein.). U(3) denotes input of retinyl ester into the liver from the diet [from 26 ]. 
age serum AP activity usually increases [27]. This observed age-related increase in serum AP activity is assumed to contribute to the concurrently observed age-related decrease in plasma PLP level. This hypothesis is corroborated by the fact that usually an inverse correlation is observed between plasma PLP concentration and serum AP activity with increasing age [28]. Correlation, however, is no proof of validity of the underlying hypothesis. In fact, several arguments can be brought against it.

Both plasma PLP concentration and serum AP activity are biochemical, and hence static, parameters. Plasma PLP level is measured directly, i.e. there is ample evidence that the concentration measured in a plasma sample is a correct approximation of the situation in plasma in vivo. Serum AP activity, on the other hand, is measured under nonphysiological circumstances, which are optimal for the assay method (the usual approach in biochemical research). First, AP activity is measured at optimum (alkaline) $\mathrm{pH}$ (approximately 8) whereas plasma $\mathrm{pH}$ is lower (7.2-7.4). Second, the inorganic phosphate concentration is kept as low as possible in the assay mixture. The higher the inorganic phosphate concentration, the more the enzyme $\mathrm{AP}$ is inhibited, resulting in a lower AP activity measured. In plasma inorganic phosphate con:entrations are considerably higher than in AP assay mixtures. The inorganic phosphate present in plasma in vivo presumably inhibits AP to some extent. Third, when measuring serum AP activity in vitro PLP is not used as substrate. Fourth, in plasma PLP is bound to albumin [29]. Protein binding protects PLP from being hydrolyzed by AP. Fifth, in the human body not only hydrolysis of PLP to PL occurs, but also formation of PLP from PL, catalyzed by PL-kinase (EC 2.7.1.35). Even if PL-kinase is present in vitro this reaction will not take place if no ATP is added to the assay mixture. In conclusion, serum AP activity as measured by standard clinico-chemical methods should be regarded as an approximation of maximum AP capacity. Most likely it is a gross overestimation of the actual in vivo role of serum AP activity in hydrolysis of plasma PLP.

Serum AP activity could be regarded as an indicator of PLP hydrolysis activity. In fact, this is the presumption behind the hypothesis that plasma PLP concentration decreases with age because (serum) AP activity increases. Following this line of reasoning, we can formulate another hypothesis: plasma PLP concentration decreases with age because total body PLP hydrolysis activity increases with age. This hypothesis now can be tested in a straightforward biokinetic experiment: PLP is dosed intravenously (into plasma) and plasma PLP disappearance is followed over time. The biokinetic parameter of interest, plasma PLP clearance, is compared between young and old people. This procedure has been applied to rats [30]. The major advantage of this approach over the static biochemical approach is that now PLP hydrolysis is measured with all regulatory mechanisms intact (even rephosphorylation of PL formed by hydrolysis of PLP is accounted for). A disadvantage of the procedure is that no information can be obtained as to which organ is predominantly responsible for total body PLP hydrolysis. The study design is a typical example of mathematical compartmental modeling. Physiological compartmental modeling might give an answer to the question which tissue is 
primarily responsible for PLP hydrolysis, but is not feasible in experiments on humans.

\section{Nulient RDA}

Another example of the possible advantage of the biokinetic over the biochemical approach is estimation of nutrient allowances. One obvious possibility to assess the daily requirement of nutrients once and for all is determining the amount that is lost daily from the body. The RDA for a nutrient would then simply be the amount required to replace this daily loss. This approach necessitates estimation of the total body pool of the nutrient of interest. This is not easily achieved by statical biochemical methods, but after administration of labeled nutrient both label dilution (and hence the nutrient body pool) and label fractional turnover rate (or daily loss of nutrient as a fraction of total body pool present) can be assessed. This method is accurate only if the nutrient of interest is in steady state in the body, i.e. if nutrient intake and nutrient loss per day are in exact equilibrium. Nutrient balance is not necessarily achieved at one level of intake per day only. The human body is capable of adapting to changes in nutrient intake to a certain extent, without obvious loss of physiological function. If, for example, protein intake is decreased, protein metabolism apparently is adjusted, resulting in lower daily protein loss [31]. Although the human body is capable of achieving a protein balance on this lower protein consumption regime, protein metabolism at this low level of intake may not be optimal (which could become manifest in case of a serious infection). Assessment of label fractional turnover rate at this low protein intake level would thus underestimate true protein supply required, to retain the human body's capacity to withstand stressful stimuli.

\section{Bile acids}

Cholic acid and chenodeoxycholic acid are the main bile acids in man [32]. Bile acids are involved in absorption of lipids from the gastrointestinal tract [33]. Recently a procedure was described for the simultaneous determination of cholic acid and chenodeoxycholic acid pool sizes and turnover rates [34]. After oral ingestion of ${ }^{2} \mathrm{H}$-labeled cholic acid and chenodeoxycholic acid both dilution of label (in serum samples) and excretion of label (into urine) were followed in time. Using the compartmental approach, pool sizes and turnover rates were calculated. The procedure was also applied to volunteers with abnormalities in bile acid metabolism: one patient with an inborn error of cholesterol synthesis and one patient with a suspected bile acid synthesis defect. The biokinetic approach proved to be of diagnostic value for determining these abnormalities. However, one drawback for the use of this procedure in (routine) diagnosis of abnormal bile metabolism is the need for frequent blood sampling. 
Vitamin A deficiency still is a major problem in large parts of the world, keratomalacia being the most severe (and irreversible) lesion. Those affected most frequently are children of pre-school age [35]. Plasma retinol concentration, a widely used vitamin A status parameter, poorly reflects individual vitamin A body store [36]. Over $90 \%$ of total body vitamin A store is accounted for by the liver [37]. Therefore, determination of vitamin A level in liver biopsy samples yields the best estimates of body stores. However, direct measurement of liver reserves from biopsied specimens is unacceptable solely for nutritional status assessment. The biokinetic approach has been suggested as a test to estimate individual total retinol body stores [38]. The socalled relative dose response test is based on the principle that when stores of retinol are high, plasma retinol is hardly affected by oral administration of vitamin A: most of the vitamin A ingested is stored in the liver quickly. However, when liver reserves are low, storage of vitamin $A$ is less efficient. Plasma retinol concentrations increase markedly, because apo-retinol binding protein in plasma is converted to holo-retinol binding protein. After oral ingestion the peak in plasma retinol is reached after approximately 5 hours. The relative dose response is calculated by assessing the increase in plasma retinol level, from pre-dose (fasting) to 5 hours post-dose, after (oral) administration of $450 \mu \mathrm{g}$ retinyl acetate equivalents [39]. This test now requires two blood samples only. (Note that theoretically total body stores of vitamin A are increased by this procedure!) For population studies, assessment of plasma retinol concentration, requiring one blood sample only, is preferred. Tanumihardjo et al. suggested to dose a biologically active, naturally occurring analogue of retinyl acetate: 3,4-dehydroretinyl acetate $[40,41]$. In this modified relative dose response test a single blood sample at approximately 5 h post-dose yields information analoguous to that from the use of two blood samples in the original relative dose response test. Unfortunately, 3,4-dehydroretinyl acetate is not currently available commercially. For individual vitamin A status assessment in patients at risk, to evaluate the effect of vitamin A therapy, the relative dose response may be applicable.

\section{Concluding remarks}

The examples discussed above are meant to illustrate the possible advantages of biokinetic experiments in nutrient research. However, biokinetic experiments should not be regarded as the ultimate solution to all problems encountered in biochemical studies, sa drawbacks of the biokinetic approach are mentioned as well. Biochemical experiments should be regarded as an invaluable tool to independently verify resuits of biokinetic experiments and, vice versa, biokinetics can be used to check conclusions obtained from biochemical data. 
1. National Academy of Sciences. Recommended Dietary Allowances, 1 th edition. Washington DC: Nalional Academy Press 1989.

2. Editorial note. Nutr Rev $1990 ; 48: 28$

3. Vir $\mathrm{SC}$. Love AHG. Vatamin B-6 status of the hospiallized aged. Am J Clin Nutr 1978:31: $1383-91$.

4. Vir SC, Love AHG. Nutritional status of institutionalized and moninstitutionalized aged in Belfast, Northern Ireland. Am J Clin Nutr 1979:32: 1934-47.

5. Garry PJ. Goodwin JS, Hunt WC, Hooper EM, Leonard AG. Nutritional status in a healthy derly population: dietary and supplemental intakes. Am J Clin Nutr 1982;36: 319-31.

6. Guilland JC, Bereksi-Reguig B, Lequeu B, Moreau D, Klepping J, Richard D. Evaluation of pyridoxine intake and pyridoxine status among aged institutionalised people. Internat J Vit Nutr Res $1984 ; 54: 185-93$.

7. MeGandy RB, Russell RM, Hart SC, Jacob RA, Tamnenbaum S, Perers H, Sahyoun N. Otradovec CL. Nutritional status survey of healthy noninstitutionalized elderly: energy and nutrient intakes from three-day diet records and nutrient supplements. Nutr Res 1986;6:785-98.

8. Löwik MRH, Westenbrink S, Hulshof KFAM, Kistemaker C, Hermus RJJ. Nutrition and aging: dietary intake of 'apparently healthy' elderly (Dutch Nutrition Surveillance System). I Am Coll Nulr 1989:8: 347-56.

9. Hamfelt A. Age variation of vitamin B-6 metabolism in man. Clin Chim Acta 1964:10:48-54.

10. Rose CS, György P, Butler M, Andres R, Norris AH, Shock NW, Tobin J, Brin M, Spiegel H. Age differences in vitamin B-6 status of 617 men. Am J Clin Nutr 1976;29:847-53.

11. Tolonen M, Schrijver J, Westermarck T, Halme M, Tuominen SEJ, Frilander A, Keinonen M, Sarnat $\mathrm{S}$. Vitamin B-6 status of Finnish elderly. Comparison with Dutch younger adults and elderly. The effect of supplementation. Intemat J Vit Nutir Res 1988;58: 73-7.

12. Hamfelt $A$, Söderhjelm L. Vitamin B-6 and aging. In: Leklem JE, Reynolds RD, Eds, Clinical and physiological applications of vitamir B-6. Current topics in nutrition and disease, vol. 19. New York: Alan R. Liss, 1988: 95-107.

13. Manore MM, Vaughan LA, Carroll SS, Leklem JE. Plasma pyridoxal-5"-phosphate concentrattion and dietary vitamin B-6 intake in free-living elderly people. Am I Clin Nutr $1989 ; 50: 339-45$.

14. Löwik MRH, van den Berg $H$, Westenbrink S, Wedel M, Schrijver J, Ockhuizen Th. Doseresponse relationships regarding vitamin B-6 in elderly people: a nationwide nutritional survey (Dutch Nutritional Surveillance System). Am J Clin Nutr 1989;50: 391-9.

15. Hoorn RKJ. Flikweert JP, Westerink D. Vitamin B-1, B-2 and B-6 deficiencies in ge riatric patients, measured by coenzyme stimulation of enzyme activities. Clin Chim Acta 1975;61: $151-62$.

16. Fonda ML, Eggers DK, Mchta R. Vitamin B-6 metabolism in the livers of young adult and senescent mice. Exp Gerontol 1980;15:457-63.

17. Fonda ML, Eggers DK. Vitamin B-6 metabolism in the blood of young adult and senescent mice. Exp Gerontol 1980:15: 465-72.

18. Fonda ML, Eggers DK. Auerbach S. Fritsch L.. Vitamin B-6 metabollism in the brains of young adult and senescent mice. Exp Gerontol 1980;15:473-9.

19. Le CM. Leklem JE. Differences in vitamin B-6 status indicator responses between young and middle-aged women fed constant diets with two levels of vitamin B-6. Am J Clin Nutr 1985;42: 226-34.

20. Milhom HT. The application of control theory to physiological systems. Philadelphia: W.B. Saunders, 1966.

21. Dost FH. Grund agen der Pharmacokinetik. Stuttgart: Georg Thieme Verlag, 1968.

22. Kübler $W$. Biokinetik als Instrument der Ernährungsforschung. XXV. Wissenschaflicher Kongress der Deutschen Gesellschaft tür Ernährung. Giessen, 14. und 15. April 1988. Kuralassungen der Vortrige. Ernahrnungs-Unsehau 1988:35: 155. 
23. Kübler $W$. Pharmacokinetic imlications of single and repeated dosage . In: Walter $P$. Brubacher GB. Stähelin HB. eds. Elevated dosages of vitamins: benefits and hazards. Toronto: Hans Huber, 1989: 30-4.

24. Kallner A, Hartmann D, Homig D. Steadyastate rumover and body pool of ascorbic acid in man. Am J Clin Nutr 1979:32: 530-9.

25. Bode W. Mocking JAJ, van den Berg H. Lower retention of ${ }^{14} \mathrm{C}$ label in old Wistar rats compared to young ones after oral dosing of ${ }^{14} \mathrm{C}$-pyridoxine. INutr (accepted).

26. Lewis $\mathrm{KC}$, Green MH. Green 』Zech LA. Retinol metabolism in rats with low vitamin A status: a compartmental model. J Lipid Res 1990:31:1535-48.

27. Keating $R$, Jones J. Elveback $L$, Randall $R$. The relation of age and sex to distribution of values in healthy adults of serum calcium, inorganic phosphorus, magnesium. alkaline phosphatase. iotal protein, albumin. and blood urea. I Lab Clin Med 1969:73: 825-34.

28. Kant AK, Moser-Veillon PB. Reynolds R.D. Effect of age on changes in plasma, erythrocyte, and urinary B-6 vitamers after an oral vitamin B-6 load. Am J Clin Nutr 1988:48; $1284-90$.

29. Anderson BB. Newmark PA, Rawlins M, Green R. Plasmat binding of vitamin B-6 compounds, Nature 1974:250:502-4.

30. Bode $\mathrm{W}$, Berg $\mathrm{H}$ van den. Pyridoxal-5' $5^{\circ}$-phosphate and pyridoxal biokinetics in aging Wistar rats. Exp Gerontol (accepted).

31. Young VR, Bier DM. A kinetic approach 10 the determination of human amino acid requirements. Nutr Rev 1987:45:289-98.

32. Salen $\mathrm{G}$, Schefer $S$. Berginer VD. Familial diseases with storage other than cholesterol. Cerebrotendinous xanthomatosis and sitosterolemia with xanthomatosis. In: Stanbury JB. Wijngaarden JB. Fredrickson DS, Goldstein JL., Brown MS, eds. The metabolic basis of inherited disease, 5th ed. New York: McGraw-Hill, 1983: 713.30.

33. Schoenfelt LJ. Diseases of the galbladder and bile ducts. In: Lsselbacher KJ. Adans RD. Braunwald E. Petersdorf RG. Wilson JD, eds. Harrison's principles ol intermal medicine, 9th ed. New York: McGraw-Hill 1980: 1489-98.

34. Koopman BJ, Kuipers F, Bijleveld CMA, van der Molen JC, Nagel GT, Vonk RI, Wolthers BG. Determination of cholic acid and chenodeoxycholic acid pool sizes and fractional turnover ranes by means of stable isotope dilution technique, making use of deuterated cholic acid and chenodeoxycholic acid. Clin Chim Acta 1988;175:143-56.

35. Amédée-Manesme O, Mourey MS. Hanck A. Therasse J. Vitamin A dose response test: validation by intravenous injection in children with liwer disease. Am J Clin Nutr 1987;46:286-9.

36. Amédée-Manesme O, Furr H, Hadchouel M, Alagille D, Olson JA. Biochemical indicators of vitamin A depletion in children with cholestasis. Hepatology 1985:5: 1143-8.

37. Olson JA. Evaluation of vitamin A status in children. Wrld Rev Nutr Diet 1978;31: 130-4.

38. Loerch JD. Lnderwood BA, Lewic KC. Response of plasma levels of vitamin A to a dose of vitamin $A$ as an indicator of hepatic vitamin A reserves in rats. J Nutr 1979;109: 778-86.

39. Campos FACS. Flores H, Underwood BA. Effect of an infection on witamin A status of children as measured by the relative dose response (RDR). Am J Clin Nutr 1987:46:91-4.

40. Tanumihardjo SA, Koellner PG. Olson JA. The modified relative-dose-response assay as an indicator of vitamin A status in a population of well-nourished American children. Am I Clin Nutr 1990;52: 1064-7.

41. Tanumihardjo SA, Muhilal, Yuniar Y, Permaesih D, Sulaiman Z, Karyadi D. Olson JA. Vitamin A status in preschool-age Indonesian children as assessed by the modified relative-dose-response assay. Am J Clin Nutr 1990:52: 1068-72. 



\section{Study design and description of experimental animals}

\section{Introduction}

The rat is a widely used and well-validated model in vitamin B-6 nutrition research [1]. Vitamin B-6 metabolic pathways and regulation mechanisms compare well for rat and man $[1,2]$. The rat is also widely used as a model in aging research because it is a relatively short-lived species. Furthermore, because of its wide use a large body of knowledge on age-related pathology has been gathered.

In the rat studies described in this thesis, the relation between vitamin B-6 and aging in the rat is assessed by comparing animals at various ages. Two different approaches were used to obtain experimental animals. In the experiments on Wistar rats, one cohort of weanling rats was obtained, which was followed longitudinally. The main advantage of this approach is that vitamin B-6 intake and other nutritional parameters could be standardized and monitored during the entire life-span of the animals. Furthermore, manipulation of the vitamin B-6 status for prolonged periods of time was easily achievable via changes of the vitamin B-6 content of the diet. The obvious disadvantage of studying one cohort of rats only is that possible cohort effects can not be noticed. In the experiments performed on Brown-Norway rats, animals were obtained from the supplier at specified ages. The Brown-Norway rats were obtained from various birth cohorts ( $1-2$ per age and sex group). Because of possible cohort effects, variation within and between groups might be larger than if one single birth cohort had been used. The main disadvantage of the Brown-Norway rats is that no data on vitamin B-6 intake are available, except that the animals had been fed a specified commercial diet from weaning, with knowledge only of the average feed intake of similar rats.

\section{Experimental animals}

\section{Whistar rats}

One cohort of newly weaned male $(n=300)$ and female $(n=300)$ Wistar rats, Bor:WISW (SPF Cpb), were obtained from F. Winkelmann, Borche, FRG. Males and females were housed separately in the Institute's animal care facility, in two well ventilated rooms at $23 \pm 1{ }^{\circ} \mathrm{C}$, a relative humidity of $50 \pm 10 \%$, and a light-dark 
Table 1. Composition of purified diets fed to Wistar rats.

\begin{tabular}{|c|c|c|c|c|}
\hline Casein & & & 250 & $\mathrm{~g} / \mathrm{kg}$ \\
\hline$d l$-Methionine & & & 2 & $\mathrm{~g} / \mathrm{kg}$ \\
\hline Wheat stareh & & & 578 & $\mathrm{~g} / \mathrm{kg}$ \\
\hline Cellulose (Solka fooc) & & & 50 & $\mathrm{~g} / \mathrm{kg}$ \\
\hline Vitamin $\mathrm{B}$ minture (without $\mathrm{B}-6$ ) & & & 2 & $\mathrm{~g} / \mathrm{kg}$ \\
\hline Thiamin $\mathrm{HCl}$ & 5 & $\mathrm{mg} / \mathrm{kg}$ & & \\
\hline Riboflavin & 6 & $m g / k g$ & & \\
\hline Nicotinic acid & 25 & $\mathrm{mg} / \mathrm{kg}$ & & \\
\hline Cyanocobalamin & 10 & $\mu g / \mathrm{kg}$ & & \\
\hline Calcium pantothenate & 15 & $\mathrm{mg} / \mathrm{kg}$ & & \\
\hline Biotin & 0.3 & $\mathrm{mg} / \mathrm{kg}$ & & \\
\hline Follic acid & 1 & $\mathrm{mg} / \mathrm{kg}$ & & \\
\hline Vitamin $B-6^{\prime}$ & & & either $<0.5$ & $\mathrm{mg} / \mathrm{kg}$ \\
\hline & & & or 3 & $\mathrm{mg} / \mathrm{kg}$ \\
\hline & & & or 6 & $\mathrm{mg} / \mathrm{kg}$ \\
\hline Jones: Foster minerals: & & & 40 & $\mathrm{~g} / \mathrm{kg}$ \\
\hline $\mathrm{KH}_{2} \mathrm{PO}_{4}$ & 15.6 & $\mathrm{~g} / \mathrm{kg}$ & & \\
\hline $\mathrm{CaCO}_{3}^{4}$ & 15.2 & $\mathrm{~g} / \mathrm{kg}$ & & \\
\hline $\mathrm{NaCl}$ & 5.56 & $\mathrm{~g} / \mathrm{kg}$ & & \\
\hline $\mathrm{MgSO}_{4}$ & 2.28 & $\mathrm{~g} / \mathrm{kg}$ & & \\
\hline $\mathrm{FeSO}_{4}^{4} 7 \mathrm{H}_{2} \mathrm{O}$ & 1.08 & $\mathrm{~g} / \mathrm{kg}$ & & \\
\hline $\mathrm{ZnCl}_{2}^{4} \mathrm{Z}^{-}$ & 10.4 & $\mathrm{mg} / \mathrm{kg}$ & & \\
\hline $\mathrm{CuSO}_{4}, 5 \mathrm{H}_{2} \mathrm{O}$ & 18.8 & $\mathrm{mg} / \mathrm{kg}$ & & \\
\hline $\mathrm{MnSO}_{4} \cdot 2 \mathrm{H}_{2} \mathrm{O}$ & 180 & $\mathrm{mg} / \mathrm{kg}$ & & \\
\hline $\mathrm{CoCl}_{2} \cdot 6 \mathrm{H}_{2} \mathrm{O}$ & 0.9 & $\mathrm{mg} / \mathrm{kg}$ & & \\
\hline $\mathrm{KI} \quad 2 \quad 2$ & 32 & $\mathrm{~min} / \mathrm{kg}$ & & \\
\hline Vitamin ADEK preparation & & & 4 & $\mathrm{~g} / \mathrm{kg}$ \\
\hline Retinyl acetale & 8450 & $1 \mathrm{U} / \mathrm{kg}$ & & \\
\hline Cholecalciferol & 2820 & $\| \mathrm{U} / \mathrm{kg}$ & & \\
\hline dl- $\alpha$-Tocopheryl acetate & 120 & $\mathrm{mg} / \mathrm{kg}$ & & \\
\hline Vilamin $\mathrm{K}$ & 4 & $\mathrm{mg} / \mathrm{kg}$ & & \\
\hline Choline chloride $50 \%$ & & & 4 & $\mathrm{~g} / \mathrm{kg}$ \\
\hline Soybean oil & & & 70 & $\mathrm{~g} / \mathrm{kg}$ \\
\hline
\end{tabular}

1 Vitamin B-6 content of diet measured wia a microbiological assay for vitamin B-6 as $\mathrm{PN} \cdot \mathrm{HCl}$, using Saccharomyces carlsbergensis (ATCC 9080) as the test organism. Diet $<0.5 \mathrm{mg} / \mathrm{kg}: 0.3 \pm 0.2 \mathrm{mg} / \mathrm{kg}$; diet $3 \mathrm{mg} / \mathrm{kg}: 3.2 \pm 0.1 \mathrm{mg} / \mathrm{kg}$; diet $6 \mathrm{mg} / \mathrm{kg}: 5.9 \pm 0.9 \mathrm{mg} / \mathrm{kg}$.

cycle of $12 / 12 \mathrm{~h}$, under clean conventional conditions. The animals were housed in groups of five in stainless steel wire mesh cages, $44 \mathrm{~cm} \times 32 \mathrm{~cm} \times 17 \mathrm{~cm}$. Each individual animal was identified by cage number combined with ear code (notches). All animals had free access to feed and tap water.

The animals were fed a purified diet from weaning, containing $250 \mathrm{~g} / \mathrm{kg}$ casein and graded levels of pyridoxine $\cdot \mathrm{HCl}(\mathrm{PN} \cdot \mathrm{HCl})$, the vitamin B-6 form commonly used in vitamin supplements (Table 1). The total cohort was randomly divided into three PN. HCl diet groups: 55 males and 55 females were fed the diet supplemented with $<0.5 \mathrm{mg} / \mathrm{kg}, 120 \mathrm{male}$ and 120 female rats with $3 \mathrm{mg} / \mathrm{kg}$, and 120 male and 120 female animals with $6 \mathrm{mg} / \mathrm{kg}$ (remaining animals were not included). The $6 \mathrm{mg} / \mathrm{kg} \mathrm{PN} \cdot \mathrm{HCl}$ diet (group) is also referred to as control diet (group). Every batch 
of feed was checked for vitamin B-6 content by means of a microbiological assay for vitamin B-6 as PN, using Saccharomyces carlsbergensis (ATCC 9080) as the test organism.

Body weight and feed intake were monitored longitudinally but water intake was not measured. Individual body weight was assessed weekly over the first 3 months, followed by monthly weighing for the entire life span of the animal. Weekly feed intake was measured per cage every week over the first 3 months and once per month thereafter. From the data obtained other parameters were callculated: body weight gain in a specified period, weekly feed intake corrected for body weight, and feed conversion efficiency (body weight gain divided by feed intake) in a specified period.

All animals were handled by experienced animal care technicians and checked daily for clinical signs. Animals judged to be in poor health or moribund were euthanized and autopsied; these animals were killed by decapitation. Autopsy was also performed on all animals found dead. The absence of a range of viral infections was monitored by regular serological examination of serum samples obtained from surplus rats (sentinels), maintained for this purpose only in the same two rooms as the experimental cohort.

At specified ages, apparently healthy rats of the desired diet and sex groups were randomly selected from different cages to be used in various experiments. If possible these animals were also autopsied (in, for example, the experiments with ${ }^{14} \mathrm{C}$-labelled vitamin $\mathrm{B}-6$ organs and remaining carcasses were used to assess ${ }^{14} \mathrm{C}$-label body distribution and a complete autopsy was therefore not feasable). The animals were sacrificed by exsanguination from the abdominal aorta, under diethyl ether anesthesia.

Autopsy was performed by trained technicians. The following organs or tissues were dissected and examined: adrenals, brain, heart, intestines, kidneys, liver, lungs, mesenteric lymph nodes, ovaries, pituitary, spleen, stomach, testes, thyroid, uterus. Any other observation judged of significance was reported as well, with emphasis on tumors and tumorous masses. All tissues mentioned above, or samples of these, and all other tissues exhibiting abnormalities were stored for further (microscopic) examination. So far, data on microscopic examination of tissues are available only for animals used in biochemical experiments.

The animals used in the various experiments performed were apparently healthy, i.e. without macroscopic and microscopic pathology, without aberrant clinical signs, and with clinical chemistry parameters within reference ranges. The only exceptions allowed were abnormalities apparently related to the low vitamin B-6 intake of the animals fed the $<0.5 \mathrm{mg} / \mathrm{kg}$ diet.

\section{Brown-Norway rats}

Pigmented Brown-Nonway rats, BN/BiRij, were obtained from the Institute for Experimental Gerontology TNO, Rijswijk, Netherlands. The animals obtained were from different birth cohorts and were aged $6-7$ months ( 6 males, 6 females), 
Table 2 Composition of the commercial diet fed to Brown-Norway rats.

\begin{tabular}{|c|c|c|c|c|c|}
\hline Grogs cremgy & 19.500 & $\mathrm{~kJ} / \mathrm{kg}$ & $\begin{array}{l}\text { Essential trace elements } \\
\text { Iron }\end{array}$ & 257.0 & $\mathrm{mg} / \mathrm{kg}$ \\
\hline Proten total & 272 & $\mathrm{~g} / \mathrm{kg}$ & Manganese & 70.4 & $\mathrm{mg} / \mathrm{kg}$ \\
\hline Protein digestible & 258 & $\mathrm{gg} / \mathrm{kg}$ & Zine & 77.0 & $\mathrm{mg} / \mathrm{kg}$ \\
\hline Arginine & 19.1 & $\mathrm{~g} / \mathrm{kg}$ & Copper & 16.0 & $\mathrm{mg} / \mathrm{kg}$ \\
\hline Lysine & 15.4 & $\mathrm{gg} / \mathrm{kg}$ & Cobalt & 0.2 & $\mathrm{mg} / \mathrm{kg}$ \\
\hline Methinonine & 5.0 & $\mathrm{~g} / \mathrm{kg}$ & lodine & 0.35 & $\mathrm{mg} / \mathrm{kg}$ \\
\hline Cystine & 4.8 & $\mathrm{~g} / \mathrm{kg}$ & Selenum & 0.29 & $\mathrm{mg} / \mathrm{kg}$ \\
\hline Tryptophan & 2.8 & $\mathrm{~g} / \mathrm{kg}$ & Tin & 1.0 & $\mathrm{mg} / \mathrm{kg}$ \\
\hline Phenyllalanine & 11.6 & $\mathrm{~g} / \mathrm{kg}$ & Chromium & 1.5 & $m g / k g$ \\
\hline Tyrosine: & 8.2 & $\mathrm{~g} / \mathrm{kg}$ & Nickel & 20 & $\mathrm{mg} / \mathrm{kg}$ \\
\hline Leucine & 19.9 & $\mathrm{~g} / \mathrm{kg}$ & Vanadium & 0.134 & $\mathrm{mg} / \mathrm{kg}$ \\
\hline Isoleucine & 11.1 & $\mathrm{~g} / \mathrm{kg}$ & & & \\
\hline Histidine & 5.9 & $\mathrm{~g} / \mathrm{kg}$ & Vitamins & & \\
\hline Threonine & 10.5 & $\mathrm{~g} / \mathrm{kg}$ & Retinyl acetate & $16,000.0$ & IU/kg \\
\hline \multirow[t]{2}{*}{ Valine } & \multirow[t]{2}{*}{15.2} & \multirow[t]{2}{*}{$\mathrm{g} / \mathrm{kg}$} & Chollecalciferol & $2,200.0$ & IU/kg \\
\hline & & & a-Tocopherol & 109.0 & $\mathrm{mg} / \mathrm{kg}$ \\
\hline Fat & & $\mathrm{g} / \mathrm{kg}$ & Vitamin $\mathrm{K}$ & 13.5 & $\mathrm{mg} / \mathrm{kg}$ \\
\hline \multirow[t]{2}{*}{ Linoleic acid } & \multirow[t]{2}{*}{35} & \multirow[t]{2}{*}{$\mathrm{g} / \mathrm{kg}$} & Thiamin & 17.2 & $\mathrm{mg} / \mathrm{kg}$ \\
\hline & & & Ribollawin & 11.4 & $\mathrm{mg} / \mathrm{kg}$ \\
\hline \multirow[t]{2}{*}{ Fiber } & \multirow[t]{2}{*}{41} & \multirow[t]{2}{*}{$\mathrm{g} / \mathrm{kg}$} & Niacin total & 90.0 & $\mathrm{mg} / \mathrm{kg}$ \\
\hline & & & Niacin available & 36.4 & $\mathrm{mg} / \mathrm{kg}$ \\
\hline \multirow[t]{2}{*}{ Other carbohydrates } & \multirow[t]{2}{*}{564} & \multirow[t]{2}{*}{$\mathrm{g} / \mathrm{kg}$} & Pantothenic acid & 21.6 & $\mathrm{mg} / \mathrm{kg}$ \\
\hline & & & Folic acid & 4.6 & $\mathrm{mg} / \mathrm{kg}$ \\
\hline Minerals & 51 & $\mathrm{~g} / \mathrm{kg}$ & Pyridoxine total & 15.2 & $\mathrm{mg} / \mathrm{kg}$ \\
\hline Calcium & 80 & $\mathrm{~g} / \mathrm{kg}$ & Pyridoxine available & 12.0 & $\mathrm{mg} / \mathrm{kg}$ \\
\hline Phosphorus & 5.8 & $\mathrm{~g} / \mathrm{kg}$ & Choline & $2,080.0$ & $\mathrm{mg} / \mathrm{kg}$ \\
\hline Potassitum & 7.4 & $\mathrm{~g} / \mathrm{kg}$ & Vitamin $B-12$ & 55.0 & $\mu \mathrm{g} / \mathrm{kg}$ \\
\hline Magnesurun & 2.3 & $\mathrm{~g} / \mathrm{kg}$ & Biotin & 300.0 & $\mu \mathrm{g} / \mathrm{kg}$ \\
\hline Sodium & 2.2 & $\mathrm{~g} / \mathrm{kg}$ & & & \\
\hline Chlorine & 3.5 & $\mathrm{~g} / \mathrm{kg}$ & & & \\
\hline
\end{tabular}

'Standard Laboratory Rat Diet AM 1 I (Hope Farms, Woerden, Netherlands); manufacturer's information.

$24-25$ months ( 6 males, 6 females), 30-31 months ( 5 males, 6 females) and $36-38$ months ( 6 males, 2 females).

The animals were bred under specific pathogen-free (SPF) conditions and maintained under clean conventional conditions at the aforementioned Institute. The animals were fed Standard Laboratory Rat Diet AM II (Hope Farms, Woerden, Netherlands) from weaning. This diet contains $272 \mathrm{~g}$ total protein and $12 \mathrm{mg}$ (available) $\mathrm{PN} \cdot \mathrm{HCl}$ per $\mathrm{kg}$ (Table 2). A detailed description of Brown-Norway husbandry is provided by Burek [3].

Upon arrival, general appearance and behavior of the animals were examined. The animals were sacrificed by exsanguination under dieth:l ether anesthesia. All animals were subjected to gross post-mortem and histopathological examinations. Routine plasma clinical chemistry parameters were measured to assess global health status and organ function. The animals included in the study were apparently 
healthy, which is defined as without major lesions and with clinical chemistry profile within reference ranges.

\section{Mortality and morbidity}

The Wistar cohort study was not designed as a long-term toxicity study. The cohort of rats was maintained primarily to obtain animals of different ages for various experiments. In the next chapters in this thesis, data are presented only on healthy 'survivors' in the cohort. In this chapter the total cohort is described, to provide background information on the large variety of animals from which only the healthy were selected for various studies. Furthermore, comparison of the three diet groups might give valuable insight in vitamin B-6 status related differences in morbidity scores.

Statistical analysis was performed on data pertaining to body weight and feed intake only. Differences between diet groups were examined by one-way analysis of variance (ANOVA), followed by least significant difference testing $(p<0.05$, $\mathrm{p}<0.01$ and $P<0.001$ ), with the $6 \mathrm{mg} / \mathrm{kg}$ diet group serving as control. Independent of the results of ANOVA, homogeneity of variances was tested by the Bartlett test, with $P<0.01$ considered to be significant.

Before the age of 2 years, mortallity rate was low (Fig. 1). The observations on morbidity of animals selected for studies under 2 years can be expected to depress the morbidity score of the corresponding diet group; these animals may well have been sacrificed before development of pathology. Morbidity scores are therefore presented for the following animals only: 1 , animals that were sacrificed in poor health or that were found dead; 2 , animals selected from the cohort for various experiments from the age of 2 years onwards; 3 , animals sacrificed at the time of termination of the experiment. The line was arbitrarily drawn at the age of 2 years to achieve a reasonable balance between depressing morbidity scores by including too many healthy animals sacrificed at younger age on the one hand, and being left with too few animals to draw any conclusion on the other. The actual numbers of animals per diet and sex group for which morbidity data are presented are given in Table 3. Statistical tests were not performed; data presented are descriptive of trends only.

\section{Montality}

Survival of the total Wistar rat cohort, corrected for animals selected for various experiments, is depicted in Fig. 1. With 'old' defined as over the age of $50 \%$ mortality, our experimental animals were considered old at an age of 27 months and over. Among the animals fed the $<0.5 \mathrm{mg} / \mathrm{kg}$ diet, survival was largely similar to that of the other diet groups. 

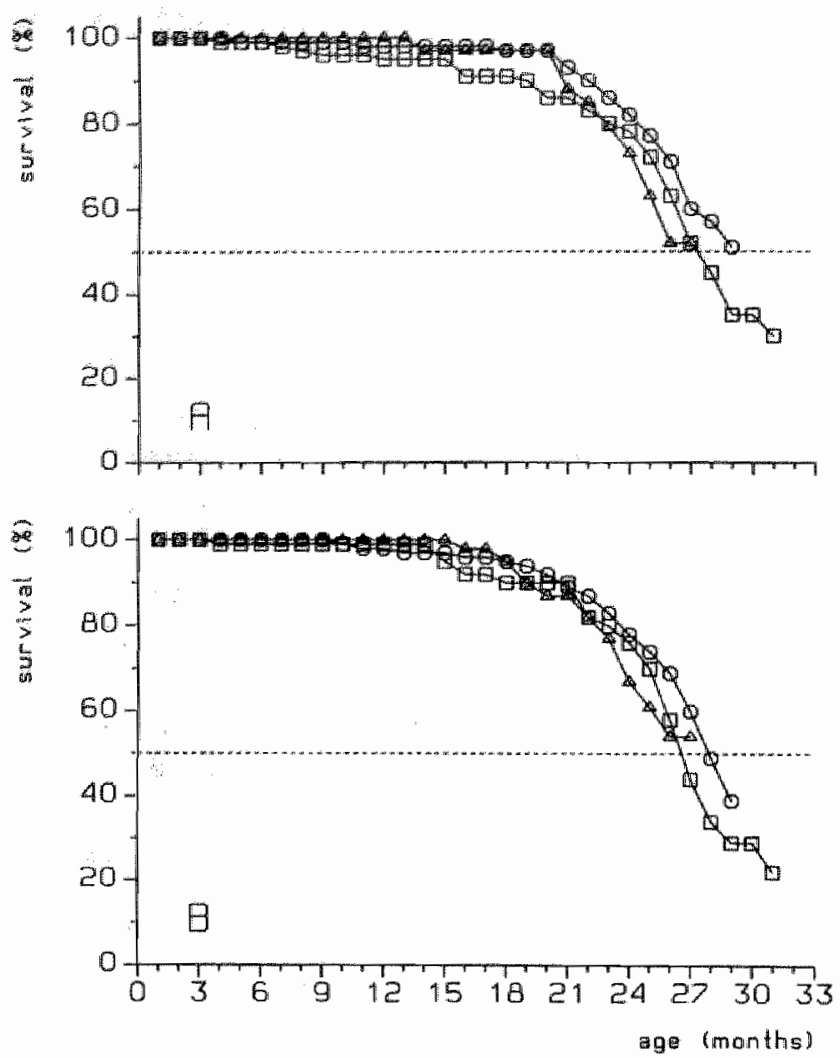

Fig. 1. Mortality of the Wistar rat cohort A, males; B. females; squares, $6 \mathrm{mg} / \mathrm{kg}$ diet (controll); circles. $3 \mathrm{mg} / \mathrm{kg}$ diet; triangles, $<0.5 \mathrm{mg} / \mathrm{kg}$ diet.

Table 3. Animals of the Wistar cohort examined macroscopically.

\begin{tabular}{|c|c|c|c|c|c|c|}
\hline \multirow[b]{2}{*}{ Diel $(\mathrm{mg} / \mathrm{kg} \mathrm{PN} \cdot \mathrm{HCl})$} & \multicolumn{3}{|c|}{ Males } & \multicolumn{3}{|c|}{ Females } \\
\hline & 6 & 3 & $<0.5$ & 6 & 3 & $<0.5$ \\
\hline Animals entering study $(n)$ & 120 & 120 & 55 & 120 & 120 & 55 \\
\hline Animals examined macroscopically $(n)$ & 67 & 71 & 42 & 93 & 107 & 43 \\
\hline Animals examined macroscopically $(\%)$ & 56 & 59 & 76 & 78 & 89 & 78 \\
\hline
\end{tabular}

Body weight

Body weight and body weight gain data of the Wistar rats are shown in Figs 2-4. Body weight of the animals fed the $<0.5 \mathrm{mg} / \mathrm{kg}$ diet was significantly lower than that of controls fed the $6 \mathrm{mg} / \mathrm{kg}$ diet (Fig. 2). For both male and female rats this 
difference already reached significance at a level of $P<0.001$ at the first scheduled weighing, after the animals had been on their respective diets for only one week. Differences in body weight between animals fed the $3 \mathrm{mg} / \mathrm{kg}$ diet and those fed the $6 \mathrm{mg} / \mathrm{kg}$ diet were not significant. The apparent decrease in body weight at higher age can at least partly be ascribed to natural selection, with light animals showing higher survival. Furthermore, pathologic processes are expected to result in weight loss.

Weekly body weight gain (data available up to 4 months of age only) was significantly lower for the animals fed the $<0.5 \mathrm{mg} / \mathrm{kg}$ diet up to approximately 3 months of age (Fig. 3). Monthly body weight gain (data available for the entire lifespan) showed a similar diet-related difference (Fig. 4). For the animals fed the $<0.5 \mathrm{mg} / \mathrm{kg}$ diet, monthly body weight gain became insignificant at approximately 9 months of age. For the animals fed the 3 and $6 \mathrm{mg} / \mathrm{kg}$ diets, this point was reached
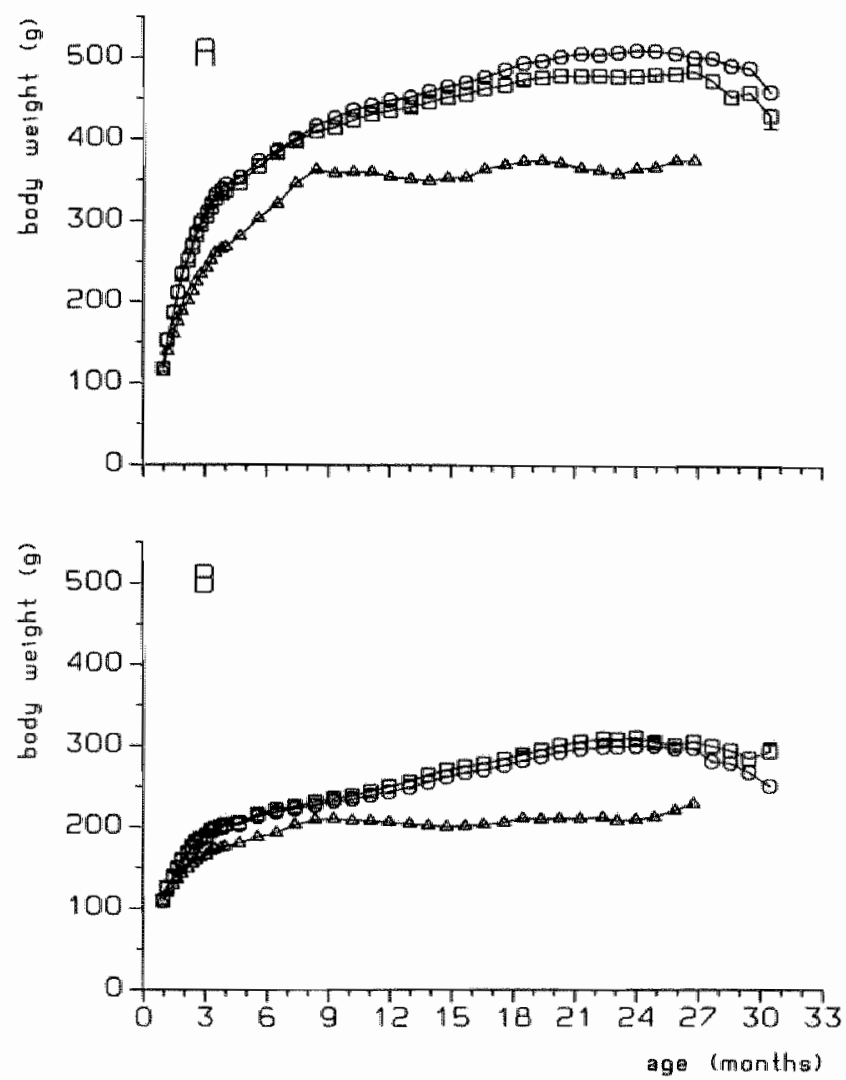

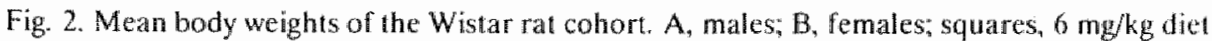
(control); circles, $3 \mathrm{mg} / \mathrm{kg}$ diet; triangles, $<0.5 \mathrm{mg} / \mathrm{kg}$ diet. For clarity sake SEM values are induded at selected ages for control rats only. 

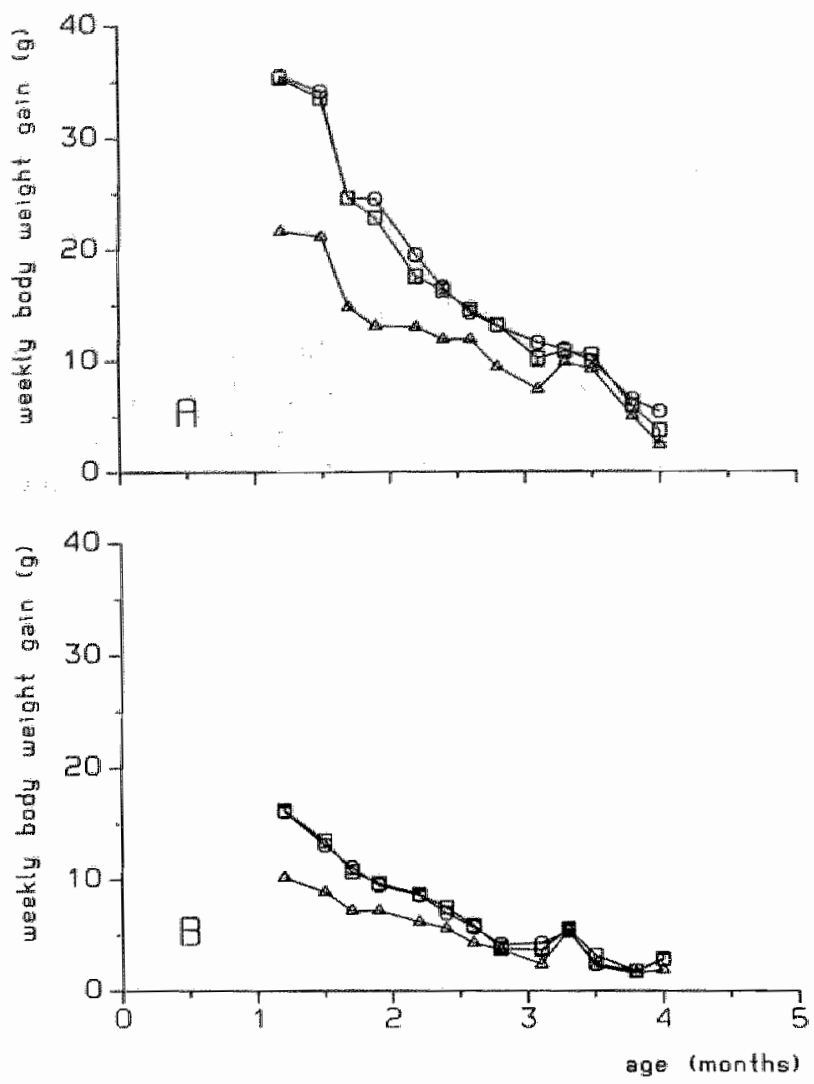

Fig. 3. Mean weekly body weight gain of the Wistar rat cohort. A, males; B, females; squares, $6 \mathrm{mg} / \mathrm{kg}$ dict (control); circles, $3 \mathrm{mg} / \mathrm{kg}$ diet triangles, $<0.5 \mathrm{mg} / \mathrm{kg}$ diet. For clarity salke SEM values are included at selected ages for control rats only.

at approximately 21 months of age for males and at approximately 23 months of age for femalles. Average monthly body weight gain was significantly below zero at the end of the experiment, when the animals were more than 2 years old, for all diet groups.

\section{Feed intake}

Weekly feed intake of the Wistar rat cohort, both absolute and corrected for body weight, is shown in Figs 5 and 6 . Feed intake was significantly lower in the $<0.5 \mathrm{mg} / \mathrm{kg}$ diet group than in controls fed the $6 \mathrm{mg} / \mathrm{kg}$ diet, except at the end of the study (Fig. 5). This difference already reached statistical significance at $P<0.001$ within one week (tirst scheduled assessment of feed intake). Feed intake per gram body weight was also significantly lower for animals fed the $<0.5 \mathrm{mg} / \mathrm{kg}$ diet than for 
controls, but only untill approximately 2 months of age (Fig. 6). From the age of 3 months feed intake per gram body weight of male rats was highest (and significantly higher than in the control group) in the $<0.5 \mathrm{mg} / \mathrm{kg}$ diet group. For female rats a similar trend was found, but the difference was not significant until approximately 15 months of age. No significant differences were observed between the 3 and $6 \mathrm{mg} / \mathrm{kg}$ diet groups. When comparing male and female rats fed the same diet, feed consumption per gram body weight was lower for females than for males during the first month of the experiment only. From the age of 2 months, feed intake corrected for body weight was higher for females than for males of the same diet group. Feed conversion efficiency (body weight gain per gram of feed consumed) was lower for female than for male rats fed the same diet, up to approximately 9 months of age (results not shown). From that age onwards, body weight gain was low anyway (Fig. 4).
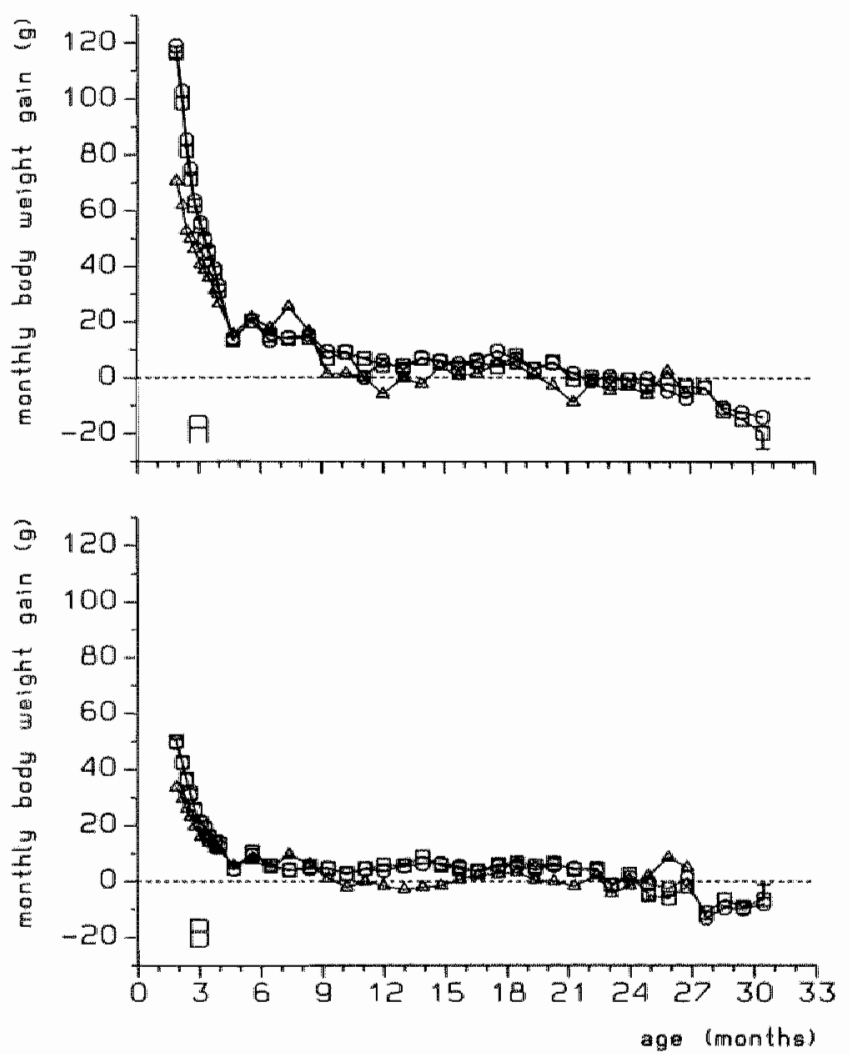

Fig. 4. Mean monthly body weight gain of the Wistar rat cohort. A, malles; B, fernales; squares, $6 \mathrm{mg} / \mathrm{kg}$ diet (control); circles, $3 \mathrm{mg} / \mathrm{kg}$ diet; triangles, $<0.5 \mathrm{mg} / \mathrm{kg}$ diet. For clarily sake SEM values are included at selected ages for control rats only. 

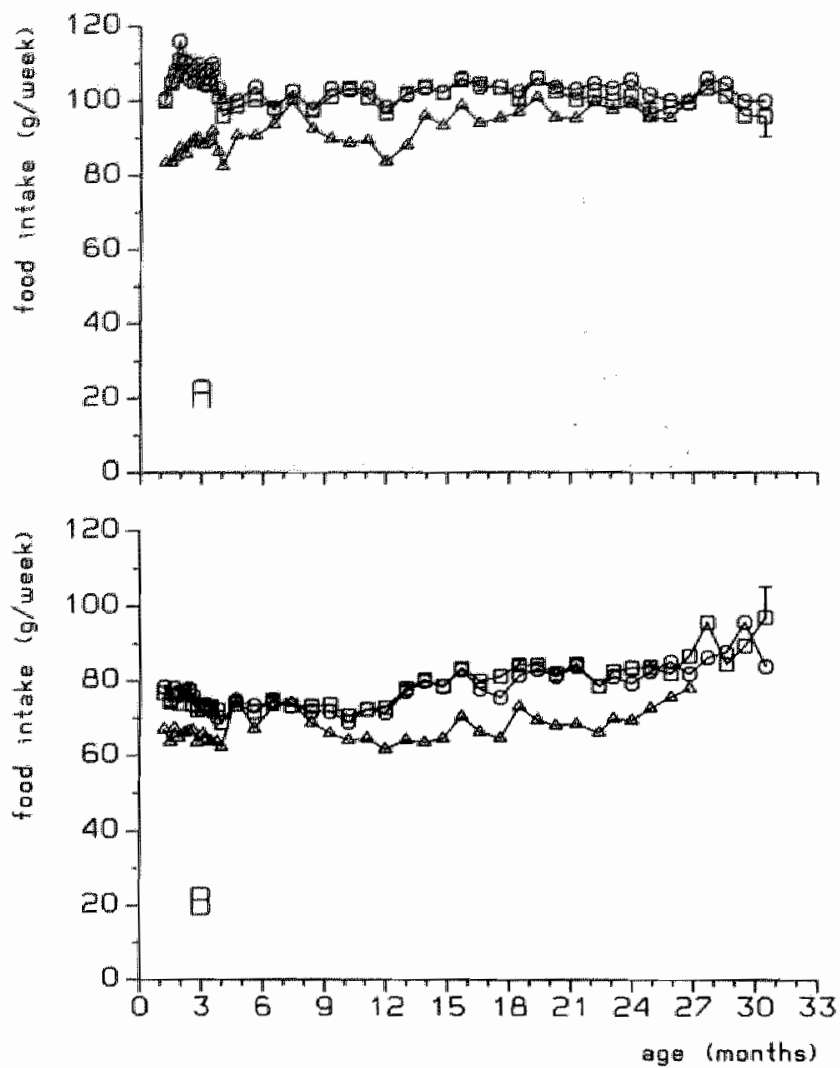

Fig. 5. Mean weekly feed consumption (cage means) of the Wistar rat cohort. A, males; B, females; squares, $6 \mathrm{mg} / \mathrm{kg}$ diet (control); circles, $3 \mathrm{mg} / \mathrm{kg}$ diet; triangles, $<0.5 \mathrm{mg} / \mathrm{kg}$ diet. For clarity sake SEM values are included at selected ages for control rats only.

Table 4. Tumorbearing animals of the Wistar cohort.

\begin{tabular}{|c|c|c|c|c|c|c|}
\hline \multirow[b]{2}{*}{ Diet (mg/kg PN/HCl) } & \multicolumn{3}{|c|}{ Males } & \multicolumn{3}{|c|}{ Females } \\
\hline & 6 & 3 & $<0.5$ & 6 & 3 & $<0.5$ \\
\hline Aninals examined macroscopically $(n)$ & 67 & 71 & 42 & 93 & 107 & 43 \\
\hline Tumor-bearing animals $(n)$ & 26 & 26 & 2 & 53 & 60 & 12 \\
\hline Tumor-bearing animals $(\%)$ & 39 & 37 & 5 & 57 & 56 & 28 \\
\hline
\end{tabular}

\section{Tumor-bearing animals}

One important morbidity parameter in long-term rat studies is the number of tumorbearing animals (Table 4). For the animals fed the $<0.5 \mathrm{mg} / \mathrm{kg}$ diet the percentage 

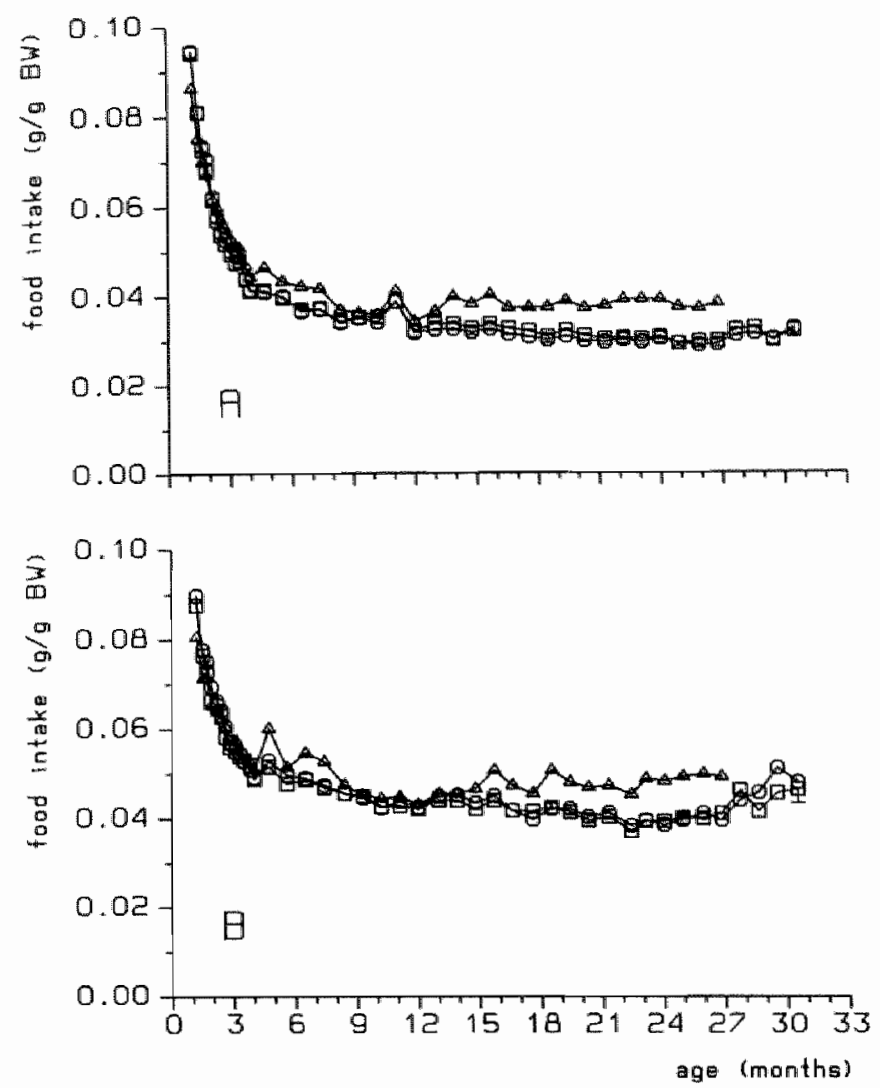

Fig. 6. Mean weekly feed consumption (cage means) corrected for body weight of the Wistar rat cohort. A, males; $B$, females; squares, $6 \mathrm{mg} / \mathrm{kg}$ diet (control); circles, $3 \mathrm{mg} / \mathrm{kg}$ diet; triangles, $<0.5 \mathrm{mg} / \mathrm{kg}$ diet. For clarity sake SEM values are included at selected ages for control rats only.

of tumor-bearing animals was remarkably lower than for the animals fed either the 3 or the $6 \mathrm{mg} / \mathrm{kg}$ diet. This might be related to the general tumor-lowering effect of long-term caloric restriction. Absolute amount of feed consumed per animal was lowest in the $<0.5 \mathrm{mg} / \mathrm{kg}$ diet group (Fig. 5). However, feed intake (and hence energy intake) calculated per $\mathrm{kg}$ body weight was highest for the $<0.5 \mathrm{mg} / \mathrm{kg}$ diet group from an age of approximately 5 months (Fig. 6). On the other hand, vitamin B-6 deficiency by itself might increase tumor resistance [4].

Spontaneous tumor development was high in the Wistar rat strain used (Table 4). Especially mammary tumors, which are externally visible or at least palpable, and pituitary tumors, visible at autopsy only, were common (Table 5). 
Table 5 . Occurrence (in \%) of specified macroscopic lesions in the Wistar rat cohort.

\begin{tabular}{|c|c|c|c|c|c|c|}
\hline \multirow[b]{2}{*}{ Diet $(\mathrm{mg} / \mathrm{kg} \mathrm{PN} \cdot \mathrm{HCl})$} & \multicolumn{3}{|c|}{ Males } & \multicolumn{3}{|c|}{ Females } \\
\hline & 6 & 3 & $<0.5$ & 6 & 3 & $<0.5$ \\
\hline
\end{tabular}

Number of animals examined macroscopically (equalling 100\%)

$\begin{array}{llllll}67 & 71 & 42 & 93 & 107 & 43\end{array}$

Habvitu, /clinical signs

Poor health condition

Anemic apearance

Dyspnea

Obesilty

Emaciation

Posterior paralysis

Incoordination

Malocclusion of incisors

Penis inflammatory aspect

Abdominal cavily

Tumorous mass

Nodule(s) adipose tissue

Enlarged lymph node(s)

Firm adipose tissue

Abdominal distension

Ascites

Hemorrhagic fluid

Edemá

Peritonitis

Discolored lymph node(s)

Abdominal wall

Nodular tissue.

Adrenals

Tumorous enlarged

Nodulers

Enlarged

Small

Cyst(s)

Discolored

Spot(s)/patches

Aorta

Irregulat surface

Dilated

Siclerosed tissue

Axillary lymph nodes

Enlarged/swollen

Discolored

Edema

Brain

Nodule(s) pallatum

Enlarged/swollen

Discolored

Soft tissue 
Table 5 (continued).

Dier (mg/kg $\mathrm{PN} \cdot \mathrm{HCl})$

Males Females

$\overline{6} 3<0.5$

$6 \quad 3<0.5$

\section{Cecum}

Nodule(s)
Small
Gaseous contents
Firm contents

Cervical tymph nodes
Enlarged
Discolored

Colon

Thickened wall

Dilated

Gaseous contents

Epididymis

Discolored

Esophagus

Food contents

Exorbital lachrymal glands

Discolored

Eyes

Enlarged

Small

Conjunctivitis

Corneal opacity

Exophthallmos

Encrustations

Harderian glands:

Tumorous enlarged

Discolored

Heart

Thrombus

Enlarged

Flabby

Discolored

Hemorrhagic appearance

Kidneys

Tumorous enlarged

Nodule(s)

Enlarged/swollen

Small

Hydronephrosis

Granular appearance

Irregular surface

Pitted surface

Cyst(s)

Discolored

Spot(s)/patches

Spongy tissue 


\begin{tabular}{|c|c|c|c|c|c|c|}
\hline \multirow[b]{2}{*}{ Dief $(\mathrm{mg} / \mathrm{kg} P \mathrm{~N} \cdot \mathrm{HCl})$} & \multicolumn{3}{|c|}{ Males: } & \multicolumn{3}{|c|}{ Females } \\
\hline & 6 & 3 & $<0,5$ & 6 & 3 & $<0.5$ \\
\hline \multicolumn{7}{|l|}{ Liver } \\
\hline Tumorous mass/tumor & 1 & 3 & - & - & $\mathbb{1}$ & - \\
\hline Nodule(s) & 1 & - & 2 & 1 & 1 & . \\
\hline Enlarged/swollen & 9 & 13 & - & 3 & 91 & 1 \\
\hline Cysin $(s)$ & - & 1 & 10 & 5 & 6 & 7 \\
\hline Granular surface & 4 & 3 & 2 & 3 & 4 & 2 \\
\hline Pronounced lobulat pattern & 4 & 11 & 2 & 8 & 9 & 2 \\
\hline Discolored & 9 & 3 & 2 & 2 & 7 & 2 \\
\hline Spot(s)/patches & 3 & 7 & 2 & 4 & 7 & - \\
\hline Constriction & - & - & 2 & - & - & - \\
\hline Adhering to diaphragm & . & - & - & - & 1. & - \\
\hline \multicolumn{7}{|l|}{ Lungs } \\
\hline Nodular tissue & - & - & - & 1 & - & - \\
\hline Swollen & 3 & 6 & - & 2 & 2 & - \\
\hline Spongy tissue & $\mathbb{1}$ & 7 & 2 & 3 & 5 & * \\
\hline Atelectasis & - & - & - & 3 & 2 & - \\
\hline Discolored & 10 & 3 & 2 & 1 & 4 & - \\
\hline Spot(s)/patches & 9 & 18 & 2 & 10 & 7 & 2 \\
\hline \multicolumn{7}{|l|}{ Mammary glands } \\
\hline Tumorous mass/tumor & - & - & - & 35 & 33 & $\mathbb{1 2}$ \\
\hline Nodule $(s)$ & - & $\rrbracket$ & $=$ & 10 & 12 & - \\
\hline Secretory activity & 6 & 1 & 2 & 42 & 42 & 7 \\
\hline Discolored & 1 & - & - & - & - & - \\
\hline Edematous tissue & - & - & - & - & 1 & - \\
\hline \multicolumn{7}{|l|}{ Mediastinal lymph node } \\
\hline Tumorous mass/tumor & 1 & - & - & 1 & 1 & - \\
\hline Nodule(s) & - & 1 & - & - & 2 & - \\
\hline Enlarged/swollen & 1 & 1 & - & 1 & 2 & - \\
\hline Discolored & . & - & - & - & 2 & - \\
\hline Edema & - & - & - & 2 & 1 & - \\
\hline \multicolumn{7}{|l|}{ Mesenteric lymph nodes } \\
\hline Tumor & - & 1 & - & 1 & - & 2 \\
\hline Nodule(s) & - & - & - & $\mathbb{1}$ & 1 & - \\
\hline Enlarged/swollen & . & 1 & 2 & 1 & 2 & - \\
\hline Vascullar dilatation & 1 & 4 & - & 2 & 7 & - \\
\hline Granular appearance & . & " & - & 1 & - & - \\
\hline Discolored & 3 & 1 & 2 & 2 & 6 & 2 \\
\hline Edema & - & - & - & 1 & 1 & - \\
\hline \multicolumn{7}{|l|}{ Meseniery } \\
\hline Nodule(s) & - & - & - & $\mathbb{1}$ & - & - \\
\hline Vascular dilatation & - & - & - & - & 1 & . \\
\hline \multicolumn{7}{|l|}{ Nasal cavity } \\
\hline Tumor & 4 & 1 & - & - & 1 & - \\
\hline Nodule(s) & - & 1 & - & 1. & " & - \\
\hline Swollen & - & 1 & - & - & 1 & - \\
\hline Inflammatory aspect & - & $\approx$ & - & - & 1 & - \\
\hline Encrustations & 10 & 8 & 38 & 11 & 15 & 19 \\
\hline Hemorthagic discharge & - & - & 2 & - & 2 & - \\
\hline Hemormagic tissue & . & - & - & - & 1 & - \\
\hline Broken & - & - & - & - & 1 & - \\
\hline
\end{tabular}


Table 5 (continued).

\begin{tabular}{lllllllll}
\hline & \multicolumn{3}{l}{ Males } & \multicolumn{3}{l}{ Famales } \\
\cline { 2 - 7 } \cline { 4 - 6 } & & 6 & 3 & $<0.5$ & 6 & 3 & $<0.5$ \\
\hline
\end{tabular}

Oral cavity

Broken upper incisor(s)

Inflammatory aspect

Ovaries

Tumorous enlarged

Enlarged

Small

Cyst(s)

Discolored

$\begin{array}{lll}1 & 3 & - \\ - & - & - \\ & & \\ & & \\ & & \\ & & \\ & & \\ & & \end{array}$

Pancreas.

Tumorous mass

Nadule(s)

Vascular dilatation

Discolored

Edema

Parathyroids

Pituitary

Enlarged

Tumorous enlarged

Nodule(s)

Enlarged/swollen

Hemorrhagic spot(s)

Discolored

Spot(s)/patches

Edematous tissue

Preputial/clitoral glands

Inflammatory aspect

$\begin{array}{rrr}1 & 3 & - \\ - & 1 & - \\ 1 & 2 & - \\ 1 & 1 & - \\ 1 & - & - \\ 19 & 21 & 19 \\ 3 & 1 & 5\end{array}$

Prostate

Tumor

Inflammatory aspect

Small

Rectum

Enlarged

Prolapse

Edema

Seminal vesicles

Inflammatory aspect

Discolored.

Small

$\begin{array}{llll}1 & - & - & - \\ 6 & 3 & - & 2 \\ - & - & 2 & 2 \\ 1 & - & - & 2 \\ - & - & - & -\end{array}$

$\begin{array}{llllll}3 & 4 & 5 & 3 & 7 & 12\end{array}$

$\begin{array}{lllll}7 & 4 & - & 32 & 33\end{array}$

$\begin{array}{lllll}7 & - & - & 3 & \\ - & 1 & 2 & 8\end{array}$

$\begin{array}{llllll}1 & 1 & 2 & 8 & 11 & 7\end{array}$

- $\quad-\quad 2 \quad 4$.

$\begin{array}{llllll}3 & 1 & 7 & 5 & 7 & 2\end{array}$

$1 \quad 3 \quad-\quad 4 \quad 10 \quad 2$

Stal muscle

Small

Skin/subcutis

Tumorous mass/tumor

Nodule(s)

Decubital ulcer(s) hind-feet

Wart

Wound

Subcutaneous edema

Alopecic area(s)

Ruffled fur

$\begin{array}{rrrrrr}16 & 11 & 5 & 1 & 1 & - \\ - & 1 & 2 & - & 3 & 2 \\ - & 1 & 7 & 6 & 7 & - \\ - & - & 5 & 3 & - & - \\ - & 6 & - & 3 & 4 & - \\ 6 & 1 & - & 1 & 3 & - \\ 21 & 14 & 67 & 71 & 53 & 84 \\ 10 & 6 & 29 & 4 & 2 & 9\end{array}$


Table 5 (continued).

\begin{tabular}{|c|c|c|c|c|c|c|}
\hline \multirow[b]{2}{*}{ Diet (mg/kg $\mathrm{PN} \cdot \mathrm{HCl}$ ) } & \multicolumn{3}{|c|}{ Males } & \multicolumn{3}{|c|}{ Females } \\
\hline & 6 & 3 & $<0.5$ & 6 & 3 & $<0.5$ \\
\hline
\end{tabular}

Skim/subcutis:

Crust(s)

Scaly

Inflammatory aspect hind leg

Small intestines

Duodenall nodule(s)

Thickened mucosa

Peyer"s patches enlarged

Dilated

Discolored content

Gaseous contents

Watery contents

Hemorrhagic appearance

Hair-ball

Spleen

Tumorous enlarged

Nodulers)

Enlarged/swollen

Small

Granular surface

Discolored

Constriction

Stomach

Nodiule(s)

Thickened mucosa

Thickened limiting ridge

Thickened wall

Erosion(s)

Hemorrhage(s)

Dilated

White deposit

Gaseous contents

Watery contents

Hemorrtangic contents

Discolored

Hait-ball

Sublingual saliwary glands

Enlarged/swollen

Discolored

Edema

Hemorthagic aspect.

Submaxillary salivary gland

Enlargedswollen

Discolored

Edena

Hemorrhagic aspect 
Table 5 (continued).

\begin{tabular}{|c|c|c|c|c|}
\hline & Males & & Females & \\
\hline Diel $(\mathrm{mg} / \mathrm{kg} \mathrm{PN} \cdot \mathrm{HCl})$ & 3 & $<0.5$ & 6 & $<0.5$ \\
\hline
\end{tabular}

Tesies

Tumorous enlarged

Enlarged

Atrophy

Discolored

Cryptorchism

Spot(s)/patches

Thoracic cavity

Hydrothorax

Hemothorax

Thymus

Tumor/tumorous enlarged

Firm tissue

Enllarged/swollen

Discolored

Edema

Thyroid

Tumorous enlarged

Enlarged

Small

Discolored

Tongue/oral caviry

Nodule(s)

Urether/urethra

Nodular tissue

Dillated

Discolored

Urinary bladder

Thickened wall

Hematuria

Dilated

Proteinaceous plug

Granular appearance

Adhering to peritoneum

Uterus

Tumorous mass/tumor

Polyp formation

Enlarged/swollen

Hydrometra

Pyometra

Discolored

Hemorrhagic issue

$\begin{array}{rrr}5 & 1 & - \\ 5 & - & - \\ 12 & 13 & 21 \\ 3 & 6 & 5 \\ 1 & 5 & 5\end{array}$

$\begin{array}{rrrrrr}13 & 11 & 10 & 3 & 8 & - \\ 1 & 1 & - & 2 & 4 & -\end{array}$

Vagina

Hemorrhagic discharge

Granular tissue

Zymbalglands

Tumor

Enlarged

- Not observed. 
Not only the incidence of tumors or tumorous mass, but also the incidence of nonneoplastic lesions in general tended to be lower for the animals fed the $<0.5 \mathrm{mg} / \mathrm{kg}$ diet than for the animals fed the 3 or $6 \mathrm{mg} / \mathrm{kg}$ diets (Table 5). This applies to adrenals, heart, liver, lungs, mammary glands, pancreas, pituitary (especially for female rats), seminal vesicles, stomach (lower incidence of hairr-balls), thymus, and uterus. On the other hand, somellesions occurred more frequently in the animals fed the $<0.5 \mathrm{mg} / \mathrm{kg}$ diet. A higher incidence of emaciation (see Table 5 under "habitus/clinical signs') might be partly related to the fact that the body weight of the animals fed the $<0.5 \mathrm{mg} / \mathrm{kg}$ diet was lower than that of the animals fed the 3 or $6 \mathrm{mg} / \mathrm{kg}$ diet (Fig. 1). A similar reasoning might be valid for the higher frequency of testicular atrophy. Some lesions are likely to be related to the low vitamin B-6 intake of the $<0.5 \mathrm{mg} / \mathrm{kg}$ diet group. Ruffled fur, alopecic areas, crusts, scaly skin, encrustations of the nasal cavity and (around) the eyes are probably all related to the typical skin lesions known to develop in vitamin B-6 deficient rats: acrodynia, a scaly dermatitis restricted to the frontal parts of the animal. The higher incidence of urinary bladder lesions might be explained by the known higher urinary oxalate excretion accompanying vitamin B-6 deficiency, leading to a higher likelihood of (calcium oxalate) stone formation. No explanation is available for the diet-related trend in thyroid lesions: compared to the 6 and $3 \mathrm{mg} / \mathrm{kg}$ diet groups, male rats fed the $<0.5 \mathrm{mg} / \mathrm{kg}$ diet showed a tendency towards a lower incidence of lesions, whereas for females an opposite trend was found. Furthermore, the corneal opacity was more frequently observed in animals fed the $<0.5 \mathrm{mg} / \mathrm{kg}$ diet is unexplained.

\section{Concluding remarks}

The observations of macroscopic lesions might well lead to the conclusion that a low vitamin B-6 intake is advantageous, at least for the rat strain studied: the mortality rate was comparable to that of rats fed diets with higher vitamin B-6 content (Fig. 1), whereas morbidity was generally lower (Tables 4 and 5). However, one important fact needs to be pointed out: the experimental animals were never challenged with any stressful stimulus. Feed (albeit with a low vitamin B-6 content) and water were always readily available; environmental conditions were never extreme; animal handling was restricted to daily inspections for clinical signs; tests including vigorous exercise programs were not performed; the animals were not subjected to infections; female rats were not mated and hence not subjected to the demands of pregnancy and lactation; if anything, the experimental animals may well have succumbed out of boredom. In our experimental protocol, the ability to cope with (external) stress factors, other than those imposed by aging or low vitamin B-6 intake itself, was not included as a parameter to be studied. 


\section{References}

1. Lumeng $L$, Li T-K. Mammalian vitamin B-6 metabolism: regulatory role of protein-binding and the hydrolysis of pyridoxal-5'-phosphate in storage and transport. In: Tryfiates GP, ed. Vitamin B-6 metabolism and role in growth. Westport: Food \& Nutrition Press, 1980: $27-52$.

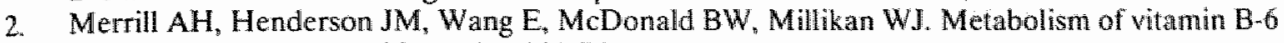
by human liver. J Nutr 1984;114: 1664-74.

3. Burek JD. Pathology of aging rats. West Palm Beach: CRC Press, 1978.

4. Stone OJ. Pyridoxine deficiency and antagonism produce increased ground substance viscosity with resulting seborrheic dermatitis and increased tumor resistance. Med Hypothesis $1989: 30$; $277-80$. 

Part II. Biochemical approach of vitamin B-6 and aging 


\section{Influence of age and sex on vitamin B-6 vitamer distribution and on vitamin B-6 metabolizing enzymes in Wistar rats}

Wilhelmina Bode, Johannes A.J. Mocking and Henk van den Berg

\section{Abstract}

Vitamin B-6 vitamer distribution and activities of vitamin B-6 metabolizing enzymes were evaluated in aging male and female Wistar rats fed a purified diet (containing $250 \mathrm{~g}$ casein and $6 \mathrm{mg}$ pyridoxine hydrochloride per $\mathrm{kg}$ ) from weaning until 31 months of age. Plasma pyridoxal-5'-phosphate (PLP) concentration became lower with increasing age, with the largest decrease in the first year of life. An age-related change in vitamin B-6 distribution between the various tissues examined was observed: B-6 vitamer content increased in heart and brain whereas PLP content decreased in gastrocnemius muscle, kidney and liver. The decrease in muscle PLP content occurred in concert with a decrease in muscle glycogen phosphorylase activity. Urinary 4-pyridoxic acid (4-PA) excretion increased with age, especially in female rats, in parallel with an increase in liver pyridoxal oxidase and pyridoxal dehydrogenase activities. Age-related changes in vitamin B-6 distribution were probably not causally related to changes in activity of vitamin B-6 metabolizing enzymes but regarded as consequences of changes in protein metabolism. The higher urinary 4-PA excretion in older rats may reflect a lower vitamin B-6 requirement; the lower PLP content of gastrocnemius muscle, however, may indicate an age-related decrease in vitamin B-6 body stores.

\section{Introduction}

One of the nutrients for which elderly people may be at risk is vitamin B-6. Observational studies on nutrient intake as well as studies on vitamin B-6 status indicate a low vitamin B-6 intake and a marginal or deficient vitamin B-6 status among the elderly [1-5]. Data published by Rose et al. suggest a gradual decrease with age of plasma pyridowal-5'-phosphate (PLP) concentration, a widelly used vitamin B-6 status indicator, by ca. $3.5 \mathrm{nM}$ per decade [6]. The more functional 
parameters of vitamin B-6 status such as the tryptophan (TRP) load test and the erythrocyte aspartate aminotransferase activation (EASAT-AC) test seem to be less affected by age $[5,71$. Supplementation of the elderly with a dose of $2-20 \mathrm{mg}$ pyridoxine (PN) per day (1-10 times the Recommended Dietary Allowance, or RDA) generally appears to be sufficient to normalize vitamin B-6 status parameters. However, in some studies $10-20 \%$ of the elderly were found not to respond $[1,3,8]$. This observed lack of response to vitamin B-6 supplementation at a physiological dose may be indicative of a change in vitamin B-6 metabolism with age, possibly resulting in higher vitamin B-6 requirements. In some human studies evidence has been presented for age-related changes in vitamin B-6 metabolism. A difference in response of plasma PLP level and 4-pyridoxic acid (4-PA) excretion into urine has been reported between young and middle-aged women under controlled dietary intake of vitamin B-6 [9]. However, in a recent study in three (male) age groups no difference in blood and plasma PLP response or in urinary 4-PA excretion after an oral PN load could be demonstrated $|10|$. Studies with rats and mice also suggest agerelated changes in vitamin $B-6$ metabolism $[11-14]$. In the brains of senescent mice evidence for an increased hydrolysis of PLP has been found [14].

The aim of the study reported here was to investigate the age-related changes in vitamin $\mathrm{B}-6$ vitamer distribution in blood and organ tissue in relation to concomitantly occurring changes in vitamin B-6 metabolizing enzyme activities. For this purpose a long-term feeding experiment with healthy Wistar rats, both male and female, was started. The animals were kept under strictly controlled conditions and were fed a vitamin B-6 adequate diet ad libitum throughout the study [15].

\section{Materials and methods}

\section{Animats and experimental protocol}

The experimental protocol was approved by an Animal Care and Use Committee. Newly weaned male and remale Wistar rats (Bor:WISW (SPF CPb), $N=120$ ) were obtained from F. Winkelmann, Borche, FRG. All animals were fed a purified diet ad libitum, containing $250 \mathrm{~g}$ casein and $6 \mathrm{mg} \mathrm{PN} . \mathrm{HCl}$ per $\mathrm{kg}$ (Table 1). They were housed in groups of live in stainless steel cages in two well ventilated rooms at $23 \pm 1{ }^{\circ} \mathrm{C}$, with a relative humidity $50 \pm 10 \%$, and a $12 \mathrm{~h} / 12 \mathrm{~h}$ light-dark cycle. All animals had free access to tap water. Body weight and food intake were monitored longitudinally for all rats.

After $6,12,18,24$ and 30 months six healthy rats of either sex were randomly selected from different cages and housed individually in stainless steel metabolism cages. Individual food intake was monitored for four days. Urine (on dry ice) and faeces were collected. Three days later, a TRP load test ( $200 \mathrm{mg}$ TRP/kg body weight administered in a single intragastric dose) was performed. At least seven days later the animals were sacrificed by exsanguination. Blood was collected from the abdominal aorta under diethyl ether anesthesia and stored on ice until 
Table 1. Composition of the diet.

\begin{tabular}{lc}
\hline Ingredient & g kg diet \\
\hline Casein & 250 \\
DL-Methionine & 2 \\
Wheat starch & 578 \\
Cellulose (Solka Floc) & 50 \\
Vitamin B mixture $^{a}$ b & 2 \\
Jones-Foster minerals & 40 \\
Vitamin ADEK preparationa $^{\text {a }}$ & 4 \\
Choline chloride $50 \%_{\text {Soybean oil }}$ & 4 \\
\end{tabular}

a For other vitamins and minerals, see ref. 16.

${ }^{b}$ Range of vitamin B-6 content measured: $4.4-8.8 \mathrm{mg} / \mathrm{kg}$ (pyridoxine. HCll).

centrifugation. Liver, heart, kidneys, brain, as well as both gastrocnemius muscles were resected and weighed. All animals were subject to gross post-mortem and histopathological examinations, and routine plasma clinical chemistry parameters were measured to assess global health status. Animals included in the study were considered apparently healthy (without major lesions and with clinical chemistry profile within reference range). Each age group contained six male and six female rats, except the group at 31 months of age, which consisted of five males and five females. Tissue homogenates were prepared as described before and stored at $-80^{\circ} \mathrm{C}$ $[16,17]$. Total homogenates were used for measurement of tissue vitamin B-6 content; protein and enzymes were assayed in $2000 \mathrm{~g}$ supernatant.

\section{Methods of analysis}

PLP in plasma, PLP, pyridoxamine-5'-phosphate (PMP), PL-kinase (ATP:pyridoxal5 '-phosphotransferase; EC 2.7.1.35) activity and PNP/PMP-oxidase (pyridoxamine$5^{\prime}$-phosphate:oxidoreductase; EC 1.4.3.5) activity in tissue samples and urinary 4-PA were measured as described earlier [16]. PLP and PMP (after nonenzymatic transamination with glyoxylic acid to PLP) were assayed radioenzymatically, 4-PA was measured by HPLC. PL-kinase assay in liver, brain and kidney was performed at $\mathrm{pH} 7$, in muscle and heart at pH 9. PLP-hydrolase (orthophosphoric-monoester phosphohydrolase, alkaline optimum; EC 3.1.3.1) activity in tissue samples was assessed according to Lumeng \& Li [18]. PL-oxidase (aldehyde:oxygen oxidoreductase; EC 1.2.3.1) and PL-dehydrogenase (aldehyde:NADP oxidoreductase; $\mathrm{EC} 1.2 .1 .4$ ) activities were measured at $\mathrm{pH} 7$ and $\mathrm{pH} 9.5$, respectively, using a modification of the method by Merrill et al. [19]; in our assays 4-PA formed was measured by HPLC. Glycogen phosphorylase (GP; 1,4- $\alpha$-Dglucan:orthophosphate- $\alpha$-glucosyltransferase; EC 2.4.1.1) activity was assayed using a modification of the method of Cori et al. [20] except that in our assay NADPH appearance was followed spectrophotometrically. Tissue protein was measured using 
the Coomassie Brilliant Blue protein assay, with BioRad reagent 500-0006 (BioRad Laboratories, Munich, FRG), according to the manufacturers' instructions. Erythrocyte enzyme activities were assayed on a Hitachi 705 analyzer (Hitachi, Tokyo, Japan); EASA T (L-aspartate:2-oxoglutarate aminotransferase; EC 2.6.1.1) activity was measured using kit 704075 from Boehringer (Mannheim, FRG) according to the manufacturers ${ }^{*}$ instructions, erythrocyte glutathione reductase (EGR; NAD(P)H:oxidized-glutathione oxidoreductase; EC 1.6.4.2) activity was measured according to Bayoumi \& Rosalki [21]. Urinary xanthurenic acid (XA) concentration was assayed as described by Schrijver et al. [22]. Plasma clinical chemistry parameters and urinary creatinine and urea levels were measured on a Cobas-Bio centrifugal analyzer (Hoffmann-La Roche, Basel, Switzerland) by standard methods according to the manufacturers' instructions.
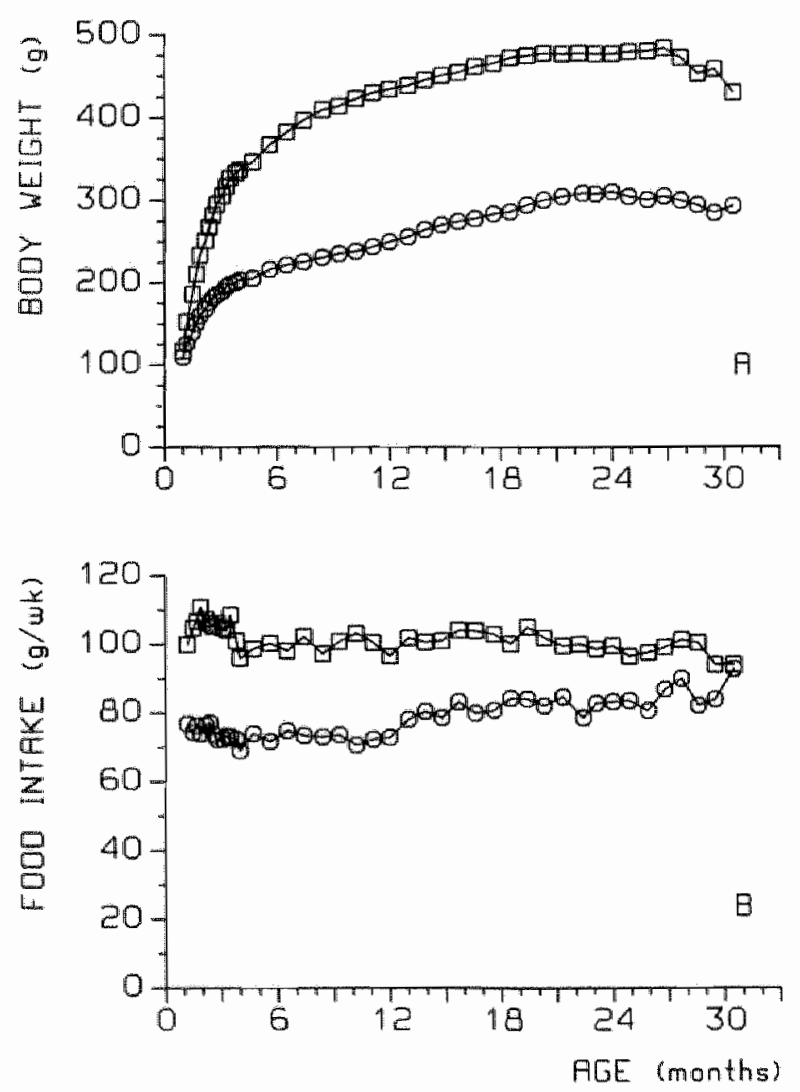

Fig. 1. Aging Wistar rats fed a synthetic diet containing $6 \mathrm{mg} / \mathrm{kg} \mathrm{PN.} \mathrm{HCl.} \mathrm{A,} \mathrm{mean} \mathrm{body} \mathrm{weight;}$

B. mean food intake (measured weekly per cage) of the total cohort; squares, males; circles, females. 
Table 2. Organ weights and tissue protein content of male and female Wistar rats at various ages.

\begin{tabular}{|c|c|c|c|c|c|c|c|c|c|c|}
\hline \multirow[t]{2}{*}{ Parameter } & \multirow[t]{2}{*}{ Sex } & \multicolumn{5}{|c|}{ Age (months) } & \multirow[t]{2}{*}{$S_{S D}{ }^{a}$} & \multicolumn{3}{|c|}{ Significance } \\
\hline & & 7 & 13 & 19 & 25 & 31 & & age & $\operatorname{sen}$ & agexsex \\
\hline \multicolumn{11}{|l|}{ Liver } \\
\hline \multirow{2}{*}{$\begin{array}{l}\text { Absolute wt } \\
(\mathrm{g})\end{array}$} & $\mathbf{M}$ & 10.31 & 1248 & 13.75 & 11.47 & 14.32 & 1.13 & $<0.001$ & $<0.001$ & $\mathrm{NS}^{\mathrm{C}}$ \\
\hline & $F$ & 6.91 & 7.41 & 8.04 & 9.14 & 11.78 & & & & \\
\hline \multirow{2}{*}{$\begin{array}{l}\text { Relative wt } \\
\text { (\% of body wt) }\end{array}$} & $\mathrm{M}$ & 2.87 & 2.97 & 288 & 2.80 & 3.34 & 0.32 & 0.005 & 0.027 & NS \\
\hline & $F$ & 3.20 & 3.09 & 3.01 & 3.10 & 4.10 & & & & \\
\hline \multirow{2}{*}{$\begin{array}{l}\text { Protein } \\
(\mathrm{mg} / \mathrm{g})\end{array}$} & $M$ & $115.5 \quad 1$ & 129.2 & 98.6 & 101.4 & 83.1 & 5.1 & $<0.001$ & NS & NS \\
\hline & $F$ & 115.2 & 141.7 & 103.5 & 101.2 & 76.5 & & & & \\
\hline \multicolumn{11}{|l|}{ Muscled } \\
\hline \multirow{2}{*}{$\begin{array}{l}\text { Absolute wr } \\
\text { (g) }\end{array}$} & $\mathbb{M}$ & 4.45 & 5.23 & 4.41 & 3.68 & 2.80 & 0.33 & $<0.001$ & $<0.001$ & 0.039 \\
\hline & F & 3.04 & 3.30 & 2.78 & 2.79 & 2.19 & & & & \\
\hline \multirow{2}{*}{$\begin{array}{l}\text { Rellative wt } \\
\text { (\% of body wt) }\end{array}$} & $\mathbb{M}$ & 1.255 & 1.245 & 0.931 & 0.900 & 0.649 & 0.089 & $<0.001$ & 0.007 & NS \\
\hline & $\mathrm{F}$ & 1.407 & 1.382 & 1.044 & 0.954 & 0.753 & & & & \\
\hline \multirow{2}{*}{$\begin{array}{l}\text { Protein } \\
\quad(\mathrm{mg} / \mathrm{g})\end{array}$} & $M$ & 42.8 & 50.0 & 46.6 & 45.9 & 41.8 & 1.1 & $<0.001$ & $<0.001$ & NS \\
\hline & $\mathbb{F}$ & 44.0 & 51.9 & 48.1 & 47.6 & 44.9 & & & & \\
\hline \multicolumn{11}{|l|}{ Heart } \\
\hline \multirow{2}{*}{$\begin{array}{l}\text { Absolute wt } \\
(\mathrm{g})\end{array}$} & $M$ & 1.135 & 1.238 & 1.358 & 1.438 & 1.912 & 0.094 & $<0,001$ & $<0.001$ & NS \\
\hline & $\mathbb{F}$ & 0.848 & 0.919 & 1.055 & 1.140 & 1.340 & & & & \\
\hline \multirow{2}{*}{$\begin{array}{l}\text { Relative wt } \\
\text { (\% of body wt) }\end{array}$} & $M$ & 0.322 & 0.295 & 0.286 & 0.349 & 0.457 & 0.034 & $<0.001$ & $<0.001$ & NS \\
\hline & $\mathbb{F}$ & 0.393 & 0.382 & $\quad 0.396$ & 0.387 & 0.466 & & & & \\
\hline \multirow{2}{*}{$\begin{array}{l}\text { Protein } \\
(\mathrm{ming} / \mathrm{g})\end{array}$} & $\mathrm{M}$ & 53.8 & 60.5 & 44.8 & 49.7 & 54.4 & 3.6 & $<0.001$ & NS & $\mathbb{N S}$ \\
\hline & $\mathbb{F}$ & 56.0 & 62.0 & 42.5 & 47.5 & 48.0 & & & & \\
\hline \multicolumn{11}{|l|}{ Brain } \\
\hline \multirow{2}{*}{$\begin{array}{l}\text { Absolute wt } \\
\text { (g) }\end{array}$} & $M$ & 1.939 & 2.070 & 2.138 & 2.098 & 2.059 & 0.060 & 0.012 & $<0.001$ & NS \\
\hline & $\mathrm{F}$ & 1.773 & 1.878 & 1.858 & 1.864 & 1.889 & & & & \\
\hline \multirow{2}{*}{$\begin{array}{l}\text { Relative wt } \\
\text { (\% of body wt) }\end{array}$} & $M$ & 0.551 & 0.493 & 0.450 & 0.519 & 0.485 & 0.035 & $<0.001$ & $<0.001$ & 0.003 \\
\hline & $F$ & 0.8240 & $\begin{array}{ll}0 & 0.787\end{array}$ & 0.698 & 0.637 & 0.654 & & & & \\
\hline \multirow{2}{*}{$\begin{array}{l}\text { Protein } \\
\text { (mg/g) }\end{array}$} & M & 37.7 & 36.1 & 32.5 & 3.7 .7 & 42.9 & 1.1 & $<0.001$ & NS & NS \\
\hline & $\mathbf{F}$ & 38.3 & 37.8 & 32.4 & 39.3 & 43.3 & & & & \\
\hline \multicolumn{11}{|l|}{ Kithoye } \\
\hline \multirow{2}{*}{$\begin{array}{l}\text { Absolute wh } \\
\text { (g) }\end{array}$} & $M$ & 2.19 & 2.68 & 2.94 & 2.77 & 3.71 & 0.21 & $<0.001$ & $<0.001$ & 0.029 \\
\hline & $\mathrm{F}$ & 1.72 & 2.00 & 2.03 & 2.3 .2 & 2.40 & & & & \\
\hline \multirow{2}{*}{$\begin{array}{l}\text { Relative wt } \\
\text { (\% of body wt) }\end{array}$} & $\mathrm{M}$ & 0.620 & 0.636 & 0.618 & 0.679 & 0.883 & 0.069 & 0.012 & $<0.001$ & NS \\
\hline & F & 0.794 & 0.835 & 0.762 & $\quad 0.790$ & 0.832 & & & & \\
\hline \multirow{2}{*}{$\begin{array}{l}\text { Protein } \\
\text { (ng/g) }\end{array}$} & $\mathrm{M}$ & 84.5 & 72.6 & 88.7 & 92.7 & 73.2 & 3.7 & $<0.001$ & NS & NS \\
\hline & $\mathbf{F}$ & 79.5 & 73.3 & 83.7 & 84.2 & 74.3 & & & & \\
\hline
\end{tabular}

a Standard error of the difference.

ANOVA using the factors age ( $7,13,19,25$ and 31 months) and sex (male, female).

CNot significant.

d Referring to left and right gastrocnemius muscle.

e Referring to both kidneys. 
Analysis of variance was performed on all data using a $2 \times 5$ factorial design with the factors sex (male/female) and age $(7,13,19,25$ or 31 months) using the GENSTAT statistical package. A probability level $<0.05$ was considered statistically significant. For all parameters investigated the standard error of the differences between means (SED) was calculated and given in the tables. T-values can be calculated by dividing the difference between two means by the corresponding SED.

\section{Results}

Body weight gain, food intake and general health status

Body weight gain and food intake of the total cohort were highest in the first months of life (Fig. 1). After about 3 months food intake remained fairly constant, with female rats showing only a slight increase. Daily food intake averaged $14 \mathrm{~g}$ for males and $11 \mathrm{~g}$ for females, corresponding with a daily PN intake of ca. $400 \mathrm{nmol}(82 \mu \mathrm{g})$ and $310 \mathrm{nmol}(65 \mu \mathrm{g})$, respectively. After the initial rapid growth phase average bodyweight increased steadily up to the age of $\mathrm{ca} .21$ months; a slight decrease was noted from 27 months onwards. The age at $50 \%$ survival was calculated to be 27 months for both males and females. The experiment was terminated at an age of 31 months, survival at that time being ca. $30 \%$.

Organ weights and protein content of the various tissues examined are shown in Table 2. Notable is the low gastrocnemius muscle weight in the older animals.

Table 3. Plasma clinical chemistry and blood parameters of male and female Wistar rats at various. ages.

\begin{tabular}{|c|c|c|c|c|c|c|c|c|c|c|}
\hline \multirow[t]{2}{*}{ Parameter } & \multirow[t]{2}{*}{$\operatorname{Sex}$} & \multicolumn{5}{|c|}{ Age (months) } & \multirow[t]{2}{*}{$S E D^{\text {at }}$} & \multicolumn{3}{|c|}{ Significan nce } \\
\hline & & 7 & 13 & 19 & 25 & 31 & & age & $\operatorname{sex}$ & $\operatorname{agc} x_{\text {sex }}$ \\
\hline \multirow{2}{*}{$\begin{array}{l}\text { Plistsmit albumin } \\
(\mathrm{g} / \mathrm{l})\end{array}$} & $M$ & 33.1 & 32.1 & 34.3 & 31.9 & 27.7 & \multirow[t]{2}{*}{1.1} & \multirow{2}{*}{$<0.001$} & \multirow{2}{*}{$<0.001$} & \multirow[t]{2}{*}{$\mathrm{NS}^{\mathrm{C}}$} \\
\hline & $\mathrm{F}$ & 38.7 & 38.5 & 39.4 & 36.4 & 31.5 & & & & \\
\hline \multirow{2}{*}{$\begin{array}{l}\text { Plasma total } \\
\text { protein }(\mathrm{g} /)\end{array}$} & $M$ & 58.5 & 62.7 & 63.2 & 66.8 & 60.5 & \multirow{2}{*}{1.7} & \multirow{2}{*}{$<0.001$} & \multirow{2}{*}{$<0.001$} & \multirow[t]{2}{*}{ NS } \\
\hline & $\mathrm{F}$ & 64.0 & 68.1 & 66.9 & 67.8 & 62.5 & & & & \\
\hline \multirow{2}{*}{$\begin{array}{l}\text { Wasma } A P \\
\text { activily }(U /)\end{array}$} & M & 115 & 118 & 118 & 106 & 134 & \multirow[t]{2}{*}{14} & \multirow[t]{2}{*}{0.005} & \multirow[t]{2}{*}{$<0.001$} & \multirow[t]{2}{*}{ NS } \\
\hline & $\mathrm{F}$ & 127 & 88 & 86 & 72 & 109 & & & & \\
\hline \multirow{2}{*}{$\begin{array}{l}\text { Mlood hemaglobin } \\
\text { (mmoln) }\end{array}$} & $\mathrm{M}$ & 9.32 & 9.47 & 9.25 & 9.20 & 9.20 & \multirow[t]{2}{*}{0.18} & \multirow[t]{2}{*}{$\mathrm{MS}$} & \multirow[t]{2}{*}{ MS } & \multirow[t]{2}{*}{ NS } \\
\hline & $F$ & 9.07 & 9.42 & 9.28 & 9.52 & 9.42 & & & & \\
\hline \multirow{2}{*}{$\begin{array}{l}\text { Blood hematocrit } \\
(1 / 1)\end{array}$} & M & 0.481 & 0.483 & 0.474 & 0.472 & 0.465 & \multirow{2}{*}{50.008} & \multirow[t]{2}{*}{ NS } & \multirow[t]{2}{*}{0.005} & \multirow[t]{2}{*}{ NS } \\
\hline & $\mathrm{F}$ & 0.451 & 0.465 & 0.466 & 0.472 & 0.465 & & & & \\
\hline \multirow[t]{2}{*}{$\operatorname{EGR}-A C$} & $\mathrm{M}$ & 11.244 & 1.341 & 1.200 & 1.262 & 1.156 & \multirow{2}{*}{60.061} & \multirow[t]{2}{*}{0.008} & \multirow[t]{2}{*}{0.014} & \multirow[t]{2}{*}{0.007} \\
\hline & $F$ & 1.263 & 1.068 & 1.154 & 1.283 & 1.092 & & & & \\
\hline
\end{tabular}

Astandard error ol the difference.

ANOVA using the factors age (7, 13, 19,25 and 31 months) and sex (male, female).

c Not signilicant. 
Table 4. Kidney function of male and female Wistar rats at warious ages.

\begin{tabular}{|c|c|c|c|c|c|c|c|c|c|c|}
\hline \multirow[t]{2}{*}{ Parameter } & \multirow[t]{2}{*}{ Sex } & \multicolumn{5}{|c|}{ Age (months) } & \multirow[t]{2}{*}{$S E D^{2}$} & \multicolumn{3}{|c|}{ Significance } \\
\hline & & 7 & 13 & 19 & 25 & 31 & & ange & $\operatorname{sen}$ & age $\mathrm{sex}$ \\
\hline \multirow{2}{*}{$\begin{array}{l}\text { Urine wolume } \\
\text { (mi) }\end{array}$} & $M$ & 3.52 & 2.38 & 2.62 & 320 & 5.47 & \multirow[t]{2}{*}{0.66} & \multirow[t]{2}{*}{$<0.001$} & \multirow[t]{2}{*}{$<0.001$} & \multirow[t]{2}{*}{$\mathrm{NS}^{\mathrm{C}}$} \\
\hline & $\mathrm{F}$ & 1.40 & 1.72 & 207 & 2.65 & 4.03 & & & & \\
\hline \multirow{2}{*}{$\begin{array}{l}\text { Urine densigy } \\
(\mathrm{g} / \mathrm{m}) \mathrm{l})\end{array}$} & $M$ & 1.0577 & 1.0637 & 1.0528 & 1.0513 & 1.0430 & \multirow{2}{*}{0.0065} & \multirow[t]{2}{*}{$<0.001$} & \multirow[t]{2}{*}{0.012} & \multirow[t]{2}{*}{ NS } \\
\hline & $\mathbb{F}$ & 1.0827 & 1.0725 & 1.0527 & 1.0525 & 1.0460 & & & & \\
\hline \multirow{2}{*}{$\begin{array}{l}G R^{d}(\mathrm{~mL} / \mathrm{min} \\
\text { per } 100 \mathrm{~g} B W)\end{array}$} & $M$ & 0.753 & 0.569 & 0.493 & 0.619 & 0.599 & \multirow{2}{*}{0.072} & \multirow[t]{2}{*}{$<0.001$} & \multirow[t]{2}{*}{0.022} & \multirow[t]{2}{*}{ NS } \\
\hline & $\mathbb{F}$ & 0.777 & 0.605 & 0.598 & 0.76 .3 & 0.669 & & & & \\
\hline
\end{tabular}

a Standard error of the difference.

B ANOVA using the factors age $(7,13,19,25$ and 31 months) and sex (male, female).

C Not significant.

- For calculation of glomular filtration rate (GFR), see ref. 23.

Some relevant plasma and blood parameters are listed in Table 3. Plasma albumin and total protein concentrations were higher in females than in males of the same age and showed slightly but significantly lower values at higher age. Plasma alkaline phosphatase (AP) activity was less in females than in males of the same age group. AP activity in plasma differed between age groups but values at 7 and 31 months were comparable. No significant age-related differences were observed for blood hemoglobin and hematocrit. EGR-AC showed significant age and sex effects, but none of the animals showed values indicating an inadequate vitamin B-2 status.

Urine concentrating capacity was lower in the older animals (Table 4). Glomular filtration rate (GFR) showed a different trend with lowest values at an age of 19 months. For calculation of GFR, see Wolfson and Kopple [23].

\section{Vitamin B-6 status parameters}

Plasma PLP level was highest at our first measurement point at 7 months, lower at 13 to 25 months and lowest at 31 months (Table 5). Female rats had a significantly higher plasma PLP concentration than males in all age groups. 4-PA excretion into urine is presented in absolute figures and as a percentage of PN intake. Males showed higher 4-PA excretion than females in all age groups. In females 4-PA excretion was higher in the older animals, in malles a more variable pattern was noted. Baseline XA excretion into urine was larger for males than for females. Male and female rats showed comparable differences between age groups, but changes were less marked in females. Total excretion of XA into urine increased in all animals after an oral TRP load, but variation was relatively large. The increase in XA excretion after loading was higher in females than in males. Male rats showed low excretion of XA after a TRP load up to the age of 25 months, but excretion was much larger at 31 months. Female rats had a different age pattern, XA excretion after TRP being higher in older animals. Basal EASAT activity (without PLP added to the reaction mixture) showed no sex difference, but a significant age effect was 
Table 5. Vitamin B-6 status parameters of male and female Wistar rats at various ages.

\begin{tabular}{|c|c|c|c|c|c|c|c|c|c|c|}
\hline \multirow[t]{2}{*}{ Pramater } & \multirow[t]{2}{*}{ Stertit } & \multicolumn{5}{|c|}{ Age (months) } & \multirow[t]{2}{*}{$\mathrm{SED}^{\mathrm{a}}$} & \multicolumn{3}{|c|}{ Significance ${ }^{b}$} \\
\hline & & 7 & 13 & 19 & 25 & 31 & & age & $\operatorname{sex}$ & age $\times$ se \\
\hline \multicolumn{11}{|l|}{ Plassmet } \\
\hline \multirow[t]{2}{*}{ PLP (nmol/) } & $M$ & 626 & 350 & 332 & 305 & 226 & 57 & $<0.001$ & $<0.001$ & $\mathrm{MS}^{\mathrm{C}}$ \\
\hline & $F$ & 704 & 556 & 436 & 489 & 381 & & & & \\
\hline \multicolumn{11}{|l|}{ Urine } \\
\hline \multirow{2}{*}{$\begin{array}{l}\text { 4. PA excretion } \\
\text { (nmold) }\end{array}$} & M & 205 & 212 & 192 & 179 & 204 & 22 & NS & $<0.001$ & NS \\
\hline & $\mathrm{F}$ & 86 & 93 & 107 & 119 & 147 & & & & \\
\hline \multirow{2}{*}{$\begin{array}{l}\text { 4.PA cxcrenion } \\
\text { (\% PN intake) }\end{array}$} & M & 45.7 & 60.8 & 46.9 & 45.6 & 66.5 & 6.8 & $<0.001$ & 0.002 & 0.038 \\
\hline & $F$ & 23,0 & 30.7 & 33.9 & 39.6 & 45.6 & & & & \\
\hline \multirow{2}{*}{$\begin{array}{l}\text { Basal XA } \\
(\mu \mathrm{mol} / \mathrm{d})\end{array}$} & $\mathrm{M}$ & 0.703 & 0.800 & 0.515 & 0.305 & 0.831 & 0.095 & $<0.001$ & $<0.001$ & 0.032 \\
\hline & $\mathbb{E}$ & 0.183 & 0.221 & 0.170 & 0.133 & 0.488 & & & & \\
\hline \multirow{2}{*}{$\begin{array}{l}\text { XA after } \\
\text { TRP }^{d}(\mu m o l / d)\end{array}$} & $M$ & 0.4 & 0.93 & 0.24 & 0.42 & 2.57 & 0.78 & 0.003 & 0.039 & 0.022 \\
\hline & $\mathrm{F}$ & 0.35 & 1.21 & 1.08 & 3.51 & 2.13 & & & & \\
\hline \multicolumn{11}{|l|}{ Enylhrocyles } \\
\hline \multirow{2}{*}{$\begin{array}{l}\text { EASAT } \\
(\mathrm{U} / \mathrm{mm} \mathrm{HB})\end{array}$} & $M$ & 392 & 617 & 420 & 834 & 875 & 84 & $<0.001$ & NS & NS \\
\hline & $F^{i}$ & 494 & 625 & 513 & 867 & 874 & & & & \\
\hline \multirow[t]{2}{*}{ EASAT-AC } & $M$ & 1.099 & 1.094 & 1.093 & 1.096 & 1.080 & 0.015 & NS & NS & NS \\
\hline & $\mathrm{F}$ & 1.098 & 1.075 & 1.075 & 1.091 & 1.082 & & & & \\
\hline
\end{tabular}

a Standard error of the difference.

b ANOVA using the factors age (7,13,19,25 and 31 months) and sex (male, female).

C" Not significant.

d Corrected for baseline XA excretion. AJI individual values $>0$.

noted: activities were higher in animals 25 and 31 months old. No significant age or sex differences were found for EASAT-AC; activation was below $10 \%$ in all animals examined.

\section{Liver vitamin B-6 metabolism}

Vitamin B -6 vitamer content and activities of vitamin B-6 metabolizing enzymes in the liver are summarized in Table 6. Mean liver PL.P concentration did not differ between males and females, and became lower with higher age. The largest difference seemed to occur between the 7 th and the 13th month of age. Liver PMP concentration, on the other hand, was higher in females than in males and showed a more variable age pattern than did liver PLP concentration. PLP and PMP concentrations present were of a similar order of magnitude. Generally PMP concentrations observed were lower than PLP concentrations, except at age 31 months, when PMP level was higher than PLP level.

For all vitamin B-6 metabolizing enzyme activities examined in the liver a significant sex effect was observed. Only PL-kinase activity was significantly larger for females, all other enzymes showed higher activities in males. Sex differences were 
Table 6. Liver B-6 vitamer content and vitamin B-6 metabolizing enzyme activities of male and female Wistar rats al various ages.

\begin{tabular}{|c|c|c|c|c|c|c|c|c|c|c|}
\hline \multirow[t]{2}{*}{ Parameter } & \multirow[t]{2}{*}{$\operatorname{sex}$} & \multicolumn{5}{|c|}{ Age (months) } & \multirow[t]{2}{*}{ SED } & \multicolumn{3}{|c|}{ Significance } \\
\hline & & 7 & 13 & 19 & 25 & 31 & & age & $\operatorname{sex}$ & ageXsex \\
\hline \multirow[t]{2}{*}{ PLP (nmol/g) } & $M$ & 35.5 & 23.5 & 24.9 & 23.5 & 19.1 & \multirow[t]{2}{*}{2.0} & \multirow[t]{2}{*}{$<0.001$} & \multirow[t]{2}{*}{$\mathrm{NS}^{\mathrm{c}}$} & \multirow[t]{2}{*}{$\mathrm{NS}$} \\
\hline & $\mathrm{F}$ & 34.1 & 26.0 & 26.2 & 24.1 & 19.5 & & & & \\
\hline \multirow[t]{2}{*}{ PMP (nmol/g) } & $M$ & 23.9 & 20.7 & 19.9 & 19.4 & 21.0 & \multirow[t]{2}{*}{1.6} & \multirow[t]{2}{*}{$<0.001$} & \multirow[t]{2}{*}{0.004} & \multirow[t]{2}{*}{0.024} \\
\hline & $\mathbb{F}$ & 23.4 & 23.5 & 20.7 & 20.5 & 27.9 & & & & \\
\hline \multirow{2}{*}{$\begin{array}{l}\text { PL-kinase (nmol/h } \\
\text { per mg protein) }\end{array}$} & $M$ & 5.2 & 6.0 & 8.9 & 8.2 & 8.4 & \multirow[t]{2}{*}{1.5} & \multirow[t]{2}{*}{$<0.001$} & \multirow[t]{2}{*}{$<0.001$} & \multirow[t]{2}{*}{ NS } \\
\hline & $F$ & 9.1 & 8.6 & 14.4 & 14.1 & 12.5 & & & & \\
\hline \multirow{2}{*}{$\begin{array}{l}\text { PLP-hydrolase (nmol/h } \\
\text { per mg protein) }\end{array}$} & $M$ & 3.67 & 2.44 & 2.74 & 2.75 & 3.94 & \multirow[t]{2}{*}{0.36} & \multirow[t]{2}{*}{$<0.00$} & \multirow[t]{2}{*}{0.012} & \multirow[t]{2}{*}{ NS } \\
\hline & $\mathbb{F}$ & 3.57 & 1.92 & 2.45 & 1.92 & 3.61 & & & & \\
\hline \multirow{2}{*}{$\begin{array}{l}\text { PNP/PMP } \times \text { oxidase (nmol/h } \\
\text { per mg protein) }\end{array}$} & $M$ & 5.13 & 4.64 & 5.88 & 6.33 & 9.32 & \multirow[t]{2}{*}{0.46} & \multirow[t]{2}{*}{$<0.00 \|$} & \multirow[t]{2}{*}{0.042} & \multirow[t]{2}{*}{ NS } \\
\hline & $F$ & 4.97 & 3.94 & 5.77 & 5.64 & 8.89 & & & & \\
\hline \multirow{2}{*}{$\begin{array}{l}\text { PL-oxidase (nmol/h } \\
\text { per mg protein) }\end{array}$} & M & 61.9 & 53.8 & 74.0 & 62.0 & 63.7 & \multirow[t]{2}{*}{7.2} & \multirow[t]{2}{*}{$<0.00 \mathrm{H}$} & \multirow[t]{2}{*}{$<0,001$} & \multirow[t]{2}{*}{0.024} \\
\hline & $\mathrm{F}$ & 39.5 & 28.1 & 43.9 & 46.6 & 66.1 & & & & \\
\hline \multirow{2}{*}{$\begin{array}{l}\text { PL-dehydrogenase (nmol/h } \\
\text { per mg protein) }\end{array}$} & $M$ & 33.1 & 32.3 & 49.0 & 38.7 & 40.7 & 4.2 & $<0.001$ & $<0.001$ & 0.006 \\
\hline & $\mathrm{F}$ & 23.5 & 19.6 & 29.1 & 30.2 & 4.4 .3 & & & & \\
\hline
\end{tabular}

a Standard error of the difference.

b ANOVA using the factors age ( $7,13,19,25$ and 31 months) and sex (male, female).

cNot significant.

small for PLP-hydrolase and PNP/PMP-oxidase, but marked for PL-kinase, PL-oxidase and PL-dehydrogenase. Age differences were variable but significant for all enzyme activities examined. Liver PL-kinase activity was higher in old animals (at an age of 25 and 31 months). Liver PLP-hydrolase activity, on the other hand, was comparable at the ages of 7 and 31 months, but was lower in between. PNP/PMP. oxidase activity was significantly higher in the 31-month-old animals only. For both PL-oxidase activity and PL-dehydrogenase activity in males no apparent trend was noted, but in females activities of both enzymes were higher in the older animals. At an age of 31 months, activities for males and females were comparable.

\section{Gastrocnemius muscle vitamin B-6 metabolism}

PLP concentration in muscle tissue became lower with increasing age from the age of 19 months onwards (Table 7). PMP concentration showed a more variable agerelated pattern. PLP was found to be the predominant vitamin B-6 vitamer in muscle tissue. Differences between age groups were somewhat less for female rats. Muscle PL-kinase activity was rather low in all samples (below detection limit when measured at $\mathrm{pH} 7.0$; data shown are activities measured at $\mathrm{pH} 9$ ) and activities were lower for the older animals. Muscle PLP-hydrolase activity showed no significant age effect, but a significant sex difference was noted (females $>$ males). GP activity showed an age pattern comparable to that of PLP, but the differences between age groups were more marked for the male rats. GP was present mainly in the form of 
Table 7. Gastrocnemus muscle B-6 vitamer content, witamin B-6 metabolizing enzyme activities and GP activity of male and female Wistar rats at various ages.

\begin{tabular}{|c|c|c|c|c|c|c|c|c|c|c|}
\hline \multirow[t]{2}{*}{ Parameter } & \multirow[t]{2}{*}{$\operatorname{sex} x$} & \multicolumn{5}{|c|}{ Age (months) } & \multirow[t]{2}{*}{$S E D^{2}$} & \multicolumn{3}{|c|}{ Significance } \\
\hline & & 7 & 13 & 19 & 25 & 31 & & age & sex & age $\times$ sex \\
\hline \multirow[t]{2}{*}{ PLP (rmoligy) } & $\mathrm{M}$ & 23.6 & 26.4 & 27.1 & 16.9 & 15.8 & \multirow[t]{2}{*}{1.8} & \multirow[t]{2}{*}{$<0.001$} & \multirow[t]{2}{*}{$\mathrm{NS}^{\mathrm{C}}$} & \multirow[t]{2}{*}{ NS } \\
\hline & $\mathrm{F}$ & 23.4 & 26.1 & 26.3 & 19.9 & 17.9 & & & & \\
\hline \multirow{2}{*}{$P M P(n m o / g)$} & $\mathrm{M}$ & 65 & 6.6 & 6.6 & 7.8 & 7.6 & \multirow[t]{2}{*}{1.0} & \multirow[t]{2}{*}{$<0.001$} & \multirow[t]{2}{*}{ NS } & \multirow[t]{2}{*}{ NS } \\
\hline & $F$ & 7.6 & 5.3 & 5.2 & 6.3 & 8.2 & & & & \\
\hline \multirow{2}{*}{$\begin{array}{l}\text { PL kinase (nmol/h } \\
\text { per ing protein) }\end{array}$} & $\mathrm{M}$ & 1.11 & 0.78 & 0.47 & 0.45 & 0.56 & \multirow[t]{2}{*}{0.17} & \multirow[t]{2}{*}{$<0.001$} & \multirow[t]{2}{*}{ NS } & \multirow[t]{2}{*}{ NS } \\
\hline & $\mathrm{F}$ & 1.43 & 0.77 & 0.44 & 0.36 & 0.46 & & & & \\
\hline \multirow{2}{*}{$\begin{array}{l}\text { PLPahydrolatse (nmol/h } \\
\text { per mg protein) }\end{array}$} & M & 1.87 & 1.50 & 159 & 1.53 & 1.62 & \multirow[t]{2}{*}{0.21} & \multirow[t]{2}{*}{ NS } & \multirow[t]{2}{*}{0.030} & \multirow[t]{2}{*}{ NS } \\
\hline & $\mathbb{F}$ & 1.94 & 1.80 & 1.86 & 1.86 & 1.72 & & & & \\
\hline \multirow{2}{*}{$\begin{array}{l}\text { GP-total d (momol/minin } \\
\text { per mis protein) }\end{array}$} & MI & 381 & 159 & 145 & 123 & 84 & \multirow[t]{2}{*}{13} & \multirow[t]{2}{*}{$<0.001$} & \multirow[t]{2}{*}{0.002} & \multirow[t]{2}{*}{ NS } \\
\hline & $F \quad 1$ & 1571 & 162 & 146 & 149 & 135 & & & & \\
\hline \multirow[t]{2}{*}{ GP'otal $(+P L P /-P L P)$} & $\mathrm{M}$ & 1.00 & 0.99 & 0.99 & 1.01 & 1.02 & \multirow[t]{2}{*}{0.01} & \multirow[t]{2}{*}{ NS } & \multirow[t]{2}{*}{ NS } & \multirow[t]{2}{*}{ NS } \\
\hline & $F$ & 1.00 & 1.00 & 1.01 & 1.00 & 1.01 & & & & \\
\hline
\end{tabular}

a standard error of the difference.

b ANOVA using the factors age $(7,13,19,25$ and 31 months) and sex (male, female).

c Not significant.

d GP-a plus GP-b activity.

GP-b, GP-a accounting for less than $5 \%$ of total activity (results not shown).

Addition of PLP to the reaction mixture did not give rise to any increase in activity.

\section{Heart vitamin B-6 metabolism}

PLP concentration in heart tissue showed higher values at advanced age, whereas PMP concentration was lower in the older animals (Table 8). PMP was the

Table 8. Heart B-6 vitamer content and vitamin B-6 metabolizing enzyme activities of male and female Wistar rats at virious ages.

\begin{tabular}{|c|c|c|c|c|c|c|c|c|c|c|}
\hline \multirow[t]{2}{*}{ Patremetor } & \multirow[t]{2}{*}{ Sen } & \multicolumn{5}{|c|}{ Age (months) } & \multirow[t]{2}{*}{ SED ${ }^{a}$} & \multicolumn{3}{|c|}{ Significance $^{b}$} \\
\hline & & 7 & 13 & 19 & 25 & 31 & & agc & $\operatorname{sex}$ & age $\times$ se \\
\hline \multirow[t]{2}{*}{ PLP (nnol/g) } & $M$ & 5.07 & 5.75 & 7.90 & 6.65 & 6.07 & \multirow[t]{2}{*}{0.38} & \multirow[t]{2}{*}{$<0.001$} & \multirow[t]{2}{*}{$\mathrm{NS}^{\mathrm{C}}$} & \multirow[t]{2}{*}{ NSS } \\
\hline & $\mathrm{F}$ & 4.84 & 5.95 & 7.98 & 7.60 & 6.16 & & & & \\
\hline \multirow[t]{2}{*}{ PMP (numol/g) } & $M$ & 19.6 & 18.7 & 20.0 & 15.2 & 16.2 & \multirow[t]{2}{*}{1.1} & \multirow[t]{2}{*}{$<0.001$} & \multirow[t]{2}{*}{ NS } & \multirow[t]{2}{*}{ NS } \\
\hline & $\mathrm{F}$ & 19.7 & 19.5 & 17.4 & 16.3 & 15.5 & & & & \\
\hline \multirow{2}{*}{$\begin{array}{l}\text { Pl-kinase (nmolh } \\
\text { per mg protein) }\end{array}$} & $M$ & 1.09 & 1.09 & 1.37 & 1.25 & 0.70 & \multirow[t]{2}{*}{0.17} & \multirow[t]{2}{*}{$<0.001$} & \multirow[t]{2}{*}{$<0.001$} & \multirow[t]{2}{*}{$\mathrm{NS}$} \\
\hline & $\mathrm{F}$ & 1.27 & 1.42 & 1.68 & 1.50 & 1.21 & & & & \\
\hline \multirow{2}{*}{$\begin{array}{l}\text { PLiplydrolase (nmol/h } \\
\text { per mg proten) }\end{array}$} & $\mathrm{M}$ & 6. 10 & 6.60 & 6.83 & 6.19 & 6.69 & \multirow[t]{2}{*}{0.48} & \multirow[t]{2}{*}{0.010} & \multirow[t]{2}{*}{0.017} & \multirow[t]{2}{*}{ NS } \\
\hline & $F$ & 6.43 & 6.75 & 8. 14 & 686 & 6.86 & & & & \\
\hline
\end{tabular}

a Standard error of the difference.

b ANOVA using the factors age (7, 13, 19,25 and 31 monihs) and sex (male, female).

Not significant. 
Table 9. Brain B-6 vitamer content and vitamin B-6 metabolizing enzyme activites of male and female Wistar rats at various ages.

\begin{tabular}{|c|c|c|c|c|c|c|c|c|c|c|}
\hline \multirow[t]{2}{*}{ Parameter } & \multirow[t]{2}{*}{ Sex } & \multicolumn{5}{|c|}{ Age (months) } & \multirow[t]{2}{*}{ SED } & \multicolumn{3}{|c|}{ Signiffucsee } \\
\hline & & 7 & 13 & 19 & 25 & 31 & & age & $\operatorname{sen}$ & a gare $\times$ sed \\
\hline \multirow[t]{2}{*}{ PLP (nmol/g) } & M & 3.61 & 3.62 & 3.92 & 3.64 & 5.74 & \multirow[t]{2}{*}{0.29} & \multirow[t]{2}{*}{$<0.001$} & \multirow[t]{2}{*}{$\mathrm{NS}^{\mathrm{C}}$} & \multirow[t]{2}{*}{ NS } \\
\hline & $\mathbb{F}$ & 3.93 & 3.66 & 4. 18 & 3.80 & 5.55 & & & & \\
\hline \multirow[t]{2}{*}{ PMP (nnol/g) } & $\mathrm{M}$ & 5.57 & 4.70 & 8.09 & 8.46 & 9.41 & \multirow[t]{2}{*}{0.34} & \multirow[t]{2}{*}{$<0.00 \mathbb{1}$} & \multirow[t]{2}{*}{0.004} & \multirow[t]{2}{*}{0.007} \\
\hline & $\mathbb{E}$ & 4.79 & 4.58 & 8.45 & 8.13 & 7.97 & & & & \\
\hline \multirow{4}{*}{$\begin{array}{l}\text { PL-kinase (nmol/h } \\
\text { per mg protein) } \\
\text { PLP-hydrolase (nmol/h } \\
\text { per mg protein) }\end{array}$} & M & 20.4 & 21.6 & 20.1 & 16.9 & 15.2 & \multirow[t]{2}{*}{1.0} & \multirow[t]{2}{*}{$<0.001$} & \multirow[t]{2}{*}{ NS } & \multirow[t]{2}{*}{ NS } \\
\hline & $\mathbb{F}$ & 20.3 & 20.8 & 20.4 & 17.0 & 14.8 & & & & \\
\hline & $\mathrm{M}$ & 38.4 & 42.4 & 48.2 & 49.0 & 41.9 & \multirow[t]{2}{*}{3.1} & \multirow[t]{2}{*}{$<0.00 \|$} & \multirow[t]{2}{*}{ NS } & \multirow[t]{2}{*}{$<0.00 \|$} \\
\hline & $\sqrt{5}$ & 34.2 & 37.3 & 60.4 & 49.5 & 37.2 & & & & \\
\hline
\end{tabular}

a Standard error of the difference.

$\mathrm{b}$ ANOVA using the factors age ( $7,13,19,25$ and 31 months) and sex (male, female).

CNot significant.

predominant vitamin B-6 vitamer at all time points. Significant sex differences were noted for PL-kinase and for PLP-hydrolase activity (females > males in both cases).

\section{Brain vitamin B-6 metabolism}

Both PLP and PMP concentrations in brain tissue were higher for the older rats (Table 9). In all samples PMP concentration was somewhat higher than PLP concentration. PL-kinase activity was lower at higher age. PLP-hydrollase activity showed a significant age effect, but no apparent pattern was observed.

Table 10. Kidney B-6 vitamer content and vitamin B-6 metabolizing enzyme activities of male and female Wistar rats at various ages.

\begin{tabular}{|c|c|c|c|c|c|c|c|c|c|c|}
\hline \multirow[t]{2}{*}{ Parameter } & \multirow[t]{2}{*}{$\operatorname{Sex}$} & \multicolumn{5}{|c|}{ Age (rnotatis) } & \multirow[t]{2}{*}{ SED } & \multicolumn{3}{|c|}{ Significance b } \\
\hline & & 7 & 13 & 19 & 25 & 31 & & age & $\operatorname{sex}$ & age $\times \operatorname{sen}$ \\
\hline \multirow[t]{2}{*}{ PLP (nmol/g) } & $M$ & 14.9 & 11.1 & 9.4 & 8.6 & 4.6 & \multirow[t]{2}{*}{1.0} & \multirow[t]{2}{*}{$<0.001$} & \multirow[t]{2}{*}{0.010} & \multirow[t]{2}{*}{$N S^{C}$} \\
\hline & $\mathrm{F}$ & 16.0 & 13.1 & 10.6 & 9.1 & 6.1 & & & & \\
\hline \multirow[t]{2}{*}{ PMP (nmol/g) } & $M$ & 24.4 & 20.1 & 22.8 & 18.0 & 12.6 & \multirow[t]{2}{*}{2.6} & \multirow[t]{2}{*}{$<0.001$} & \multirow[t]{2}{*}{ NS } & \multirow[t]{2}{*}{$\mathrm{NS}$} \\
\hline & $\mathrm{F}$ & 22.1 & 17.0 & 19.8 & 15.5 & 12.4 & & & & \\
\hline \multirow{2}{*}{$\begin{array}{l}\text { PL-kinase (rmol/h } \\
\text { per mg protein) }\end{array}$} & $M$ & 21.5 & 19.9 & 14.9 & 14.1 & 12.6 & \multirow[t]{2}{*}{1.4} & \multirow[t]{2}{*}{$<0.001$} & \multirow[t]{2}{*}{ NS } & \multirow[t]{2}{*}{$\mathrm{NS}$} \\
\hline & $\mathbf{F}$ & 20.2 & 18.3 & 16.1 & 14.9 & 13.3 & & & & \\
\hline \multirow{2}{*}{$\begin{array}{l}\text { PLP-hydrolase (mmol/h } \\
\text { per mg protein) }\end{array}$} & $M$ & 614 & 503 & 447 & 364 & 288 & \multirow[t]{2}{*}{91} & \multirow{2}{*}{\multicolumn{2}{|c|}{$<0.001<0.001$}} & \multirow[t]{2}{*}{ NS } \\
\hline & $F$ & 876 & 866 & 595 & 625 & 300 & & & & \\
\hline
\end{tabular}

Standard error of the difference.

ANOVA using the factors age (7, 13, 19.25 and 31 months) and sex (male, female).

Nat significant. 
All vitamin B-6 related parameters measured in kidney showed lower values at higher age (Table 10). PMP concentations found were higher than corresponding PLP concentrations. Significant sex differences were noted for PLP-hydrolase activity (females $>$ males).

\section{Discussion}

The rat is a widely used and well validated model in vitamin B-6 metabolism research [24]. Vitamin B-6 metabolic pathways and regulatory mechanisms in man compare well with those in rats $[19,24]$. Recommended daily vitamin B-6 intake, expressed per $\mathrm{kg}$ of body weight, is much higher in rats than in man (ca. $0.5 \mathrm{mg} / \mathrm{kg}$ vs. $0.03 \mathrm{mg} / \mathrm{kg}$ ). However, relative to protein intake, recommended witamin B-6 intakes diverge much less: $20 \mu \mathrm{g} / \mathrm{g}$ protein for man, $25-30 \mu \mathrm{g} / \mathrm{g}$ protein for rats. In (severe) vitamin B-6 deficiency both humans and rats show characteristic hematological and neurological symptoms and impaired cellular and humoral immune response $[25,26]$.

Our study with aging Wistar rats clearly demonstrates age-dependent changes in vitamin B-6 distribution and vitamin B-6 metabolism. Some changes already occur at younger age. Several parameters examined show highly significant sex differences, but generally age effects are comparable for males and females. Although the study design was not strictly longitudinal, differences between age groups are considered to reflect age-dependent increases or decreases: the animals were taken at specific ages from the same cohort which was kept under strictly standardized conditions. Body weight gain, food intake and mortality rate of the cohort studied compared well with earlier experiments performed in our Institute using the same strain of rats. To discriminate between pathology-related and intrinsic aging effects, assessment of general health status is essential. From histopathological observations, plasma clinical chemistry profiles and kidney function parameters it was conchded the animals used in our experiments were in an apparantly healthy condition.

\section{Age-related changes in witamin B-6 status parameters}

The age-dependent changes in vitamin B-6 status parameters observed in our cohon of aging rats (Table 5) compared rather well with those observed in humans. We found relatively high plasma PLP levels at young age, lower but constant levels in midlife, and a further decrease at older age, closely resembling the changes in humans 171. We did not measure plasma PL levels, although this B-6 vitamer has been reported to be present in (rat) plasma in significant amounts as well [16]. Two plasma parameters are thought to be of importance in regulating PLP concentration, namely albumin concentration and AP activity. PLP in plasma is present in the form of an albumin complex [27]. Albumin binding protects PLP against rapid hydrolysis 
to PL mediated by AP [28]. An age-related decline in albumin-binding capacity might at least partly explain the observed age-related decrease in plasma PLP level. The observed age-related decrease in plasma albumin, although highly significant, was relatively small compared to the observed decrease in plasma PLP level (Table 3). Furthermore, albumin-binding capacity far exceeds the plasma PLP levels found in our animals, even at old age when albumin levels were low [28]. Liver perfusion studies recently performed in our laboratory indicated that the release of albuminPLP complex from isolated perfused rat liver was comparable for young (6 months) and old (31 months) animals (unpublished results). Several authors have suggested a causal relationship between plasma AP activity and plasma PLP concentration. Patients with hypophosphatasia have extremely high plasma PLP levels, while in patients with liver or skeletal disease, the higher plasma AP activity is generally associated with lower plasma PLP levels [29]. Coburn and White postulate that (tissue-nonspecific) AP may regulate the extracellular concentration of PLP. However, our data on rats do not indicate a relationship between plasma PLP level and plasma AP activity.

The more functional parameters of vitamin B-6 status, i.e. increase in XA excretion after TRP loading and EASAT-AC test, did not indicate an inadequate vitamin B-6 status at higher age. The higher basal and stimulated urinary XA excretion were still within the normal range and probably reflect an age-related effect. on TRP metabolism rather than an increased vitamin B-6 requirement. Although the unstimulated EASAT activity showed a significant increase with age, the stimulation ratio EASAT-AC remained at a constant low level.

Relative 4-PA excretion tended to become higher with increasing age; in female rats this trend was highly significant. The parallel increase in PL-oxidase and PL-dehydrogenase activities in the livers of female rats (Table 6) is suggestive of a causal relationship. Free intracellular PL is the substrate for both PL-oxidase (dehydrogenase) and PL-kinase. Both enzyme activities increase with age. However, free intracellular PL concentration is probably low due to protein binding of PLP, which protects PLP against dephosphorylation by action of PLP-hydrolase [19].

The oxidation of PL to 4-PA is irreversible. Obligatory losses of vitamin B-6 as 4-PA probably are very small as 4-PA excretion is very low, if present at all, in vitamin B-6 deficient animals. The increase in urinary 4-PA excretion with higher age may therefore reflect a decrease in PLP-binding capacity in the liver concurrent with an increase in PL-oxidase and PL-dehydrogenase activities.

Urinary 4-PA excretion theoretically could have been influenced by age-related loss of kidney function. Although a decrease in urine concentrating capacity with age was noted, GFR showed a different age pattern: animals at an age of 19 months showing the lowest values. Therefore, in the experimental animals, renal clearance of vitamine $\mathrm{B}-6$ is not likely to be influenced by age. 
Aging seems to be accompanied with a change in vitamin B-6 distribution between various body compartments. This is illustrated in Fig. 2. Brain and heart tissue were shown to accumulate PLP and PMP while kidney and muscle tissue contents decreased with age. Especially the total amount of PLP and PMP present in gastrocnemius muscle tissue was strikingly lower in the older animals. This decrease is the combined effect of the decrease in especially muscle PLP concentration and the decrease of muscle weight with age (Tables 7 and 2 , respectively).

PLP and PMP are the predominant forms of vitamin B-6 in mammalian tissues [24]. The ratio PMP/PLP, however, is dependent on the organ tissue examined. In our experimental animals, the PMP/PLP ratio was lowest in muscle tissue, i.e. below 0.5 , approximately 1 in liver tissue, between 1 and 2 in brain and kidney tissue and over 2 in heart tissue (Tables 6-10). These values compare well with earlier findings [24]. Age-related changes in total B-6 vitamer content seem to be correlate well with the PMP/PLP ratio found for the corresponding tissue samples. Brain and heart (ratio $>1$ ) showed an increase in total organ B-6 vitamer content with age, liver B-6 vitamer content (ratio ca. 1) was hardly affected by age, and muscle tissue (ratio < 0.5 ) showed a decrease in total B-6 vitamer content. Kidney tissue was the only exception: its $\mathbb{B}-6$ vitamer content decreased with age while the PMP/PLP ratio was larger than 1 . This could be related to the known age-related loss of functional kidney tissue. The kidney function tests performed on the animals examined indeed showed a decrease of urine concentrating capacity with age (Table 4). A possible explanation for the relation between organ PMP/PLP ratio and change in vitamin B-6

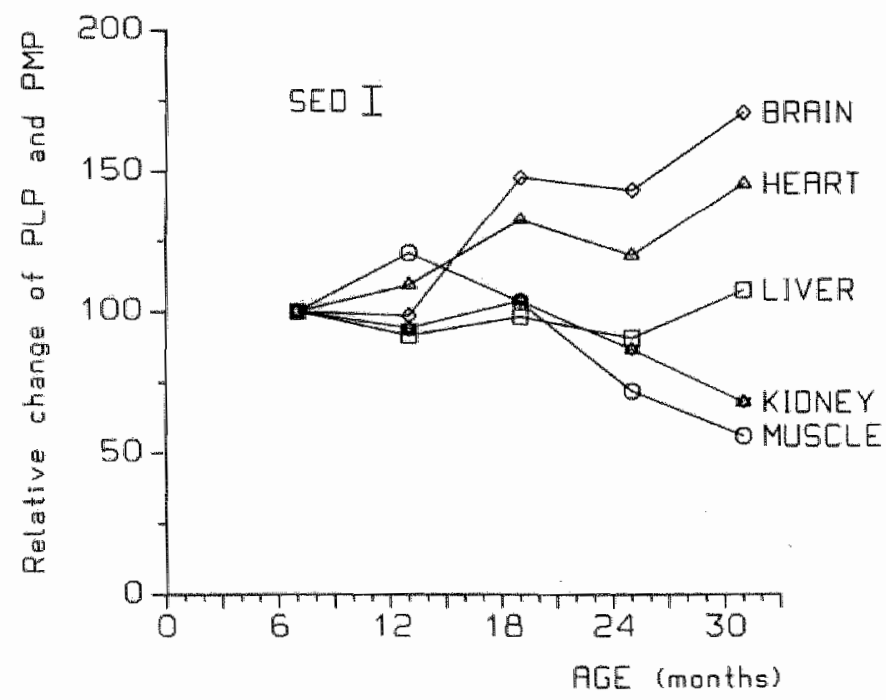

Fig. 2. Relative changes in total organ PLP and PMP content (calculated as (concentration of $P L P+P M P \mid$ organ weight) of male and female Wistar tats combined $(n=12)$, Value at age 7 months is set at $100 \%$ SED. standard enror of the difference. 
content with age could be intracellular compartmentalization of vitamin B-6 vitamers into slow (mostly mitochondrial PMP) and fast (mostly cytosolic PLP) pools $[17,30,31]$. PMP can regarded as 'trapped' PLP, probably the result of increased protein catabolism $[17,32]$.

The age-induced changes in vitamin B-6 distribution are not easily explained by the concomitant changes in vitamin B-6 metabolizing enzyme capacities. In liver, quantitatively the most important organ with respect to vitamin B-6 metabolism, PLP synthesizing capacity, i.e. PL-kinase and PNP/PMP-oxidase activities, increased with age (Table 6). Liver PLP-hydrolase activity did not show a clear age-related trend, but was never significantly higher than at an age of 7 months. The only physiologically significant changes observed were the increases in PL-oxidase and PLdehydrogenase activities. Neither changes in synthesizing capacity, nor in degrading capacity of liver vitamin B-6 metabolizing enzymes were congruent with the observed age-related decrease in liver (PLP) concentration. Similar conclusions were drawn for all organs examined. Although age-related trends in enzyme activities were the same for male and female rats, significant differences in activities were observed between sexes. Sex hormones have been reported to affect vitamin B-6 metabolism $[33,34]$. However, differences in hormonal environment cannot easily explain sexand/or age-related differences in vitamin B-6 distribution.

The study of Fonda et al. has frequently been cited to illustrate the age-related increase in brain PLP-hydrolase activity, or even the age-related increase in PLP-hydrolase activity in any tissue examined [14]. However, the evidence from this study is only indirect, as no PLP-hydrolase activities were actually measured. In our study, PLP-hydrolase activity at an age of 31 months was mot significantly higher than at an age of 7 months in any organ examined including the brain.

The decrease in muscle PLP content may have important consequences with respect to vitamin B-6 body stores. Muscle tissue accounts for approximately $40 \%$ of body weight. About $80 \%$ of total vitamin B-6 body store is located within the lean body mass. If the decreasing PLP concentration of gastrocnemius muscle is representative of all (striated) muscle this may reflect a decrease of vilamin $\mathbf{B}-6$ body stores with increasing age.

The decrease in muscle PLP concentration with age seems not to be the result of limited vitamin B-6 supply but may be related to decreasing protein-binding capacily. GP is the major PLP-binding protein in muscle tissue $[30,35]$. In the muscle samples examined, muscle GP activity (GP- $a+$ GP- $b$, total activity) and muscle PLP concentration followed roughly the same trend with age (Table 7). Virtually no apoenzyme GP was found to be present as no increase of in witro GP activity was observed when PLP was added in excess. There is still some uncertainty about the role of muscle tissue as a vitamin B-6 depository and about the factors regulating the release of muscle PLP [36]. One might expect that PLP turnover in muscle tissue depends on GP turnover. Muscle protein turnover depends on various factors, such as physical activity. Beynon et al. have studied GP activity in mouse skeletal muscle under muscle-wasting conditions, i.e. dystrophy or denervation [37]. In control animals the GP degradation rate was calculated to be $5.8 \%$ per day which compared 
well with the observed fractional synthesis rate of $4.7 \%$ per day. In both denervated and dystrophic muscle tissue a higher rate of degradation was noted. In dystrophic animals only, indications for a higher GP synthesis rate were found. Data regarding the age effect on total muscle protein tumover are conflicting [38]. Some studies report an increased turnover. However, wotal muscle protein mass decreases with age. Factors affecting energy and nitrogen balance at old age may therefore secondarily affect vitamin B-6 metabolism and vitamin B-6 storing capacity. This implicates improvement of vitamin B-6 status in general (if necessary) would not only require measures to improve vitamin B-6 intake, but also measures to prevent a negative energy and protein balance. More research into the complex interaction between vitamin B-6 and protein metabolism is needed, especially during the aging process.

In conclusion, we did find age-related changes in vitamin B-6 distribution and in vitamin B-6 metabolizing enzyme activities. The results are schematically summarized in Table 11. The most relevant findings were the age-related increase in liver PLoxidase and PL-dehydrogenase activities (parallelled by the age-related increase in urinary 4-PA excretion, Table 5), and the observed age-induced redistribution of vitamin B-6 vitamers. The decrease in muscle PLP concentration, together with the clecrease in gastrocnemius muscle mass, especially in very old rats, may reflect lower vitamin B-6 body stores for the older animals.

Whether these age-related changes have functional consequences cannot be concluded from this study. Some studies have shown a relationship between inadequate vitamin B-6 status and impaired immune response in the elderly [39]. In our Institute rat studies are in progress to evaluate the effect of age and vitamin B-6 intake on functional criteria of vitamin B-6 status, i. e. immune status and learning capacity. In this way it is possible to discriminate between adaptational responses to changes in vitamin B-6 distribution on the one hand and functional changes in

Table 11 . Schematic presentation of age-related changes in vitamin B-6-related parameters in male and female Wistar fats.

\begin{tabular}{|c|c|c|c|c|c|c|}
\hline Parameter & Plasma & Liver & Muscle & Heart & Brain & Kidney \\
\hline PLP concentiation & $\downarrow$ & $\downarrow$ & $\downarrow$ & $\uparrow$ & $\uparrow$ & $\star$ \\
\hline PMP concentration & ND & $\infty$ & $\sim$ & $\downarrow$ & 1 & $\downarrow$ \\
\hline Total (PLP+ PMP) content & ND & - & 4 & $\uparrow$ & 1 & $\downarrow$ \\
\hline PL-kinase activity & $\mathrm{ND}$ & $\uparrow$ & $\downarrow$ & $\sim$ & $\Downarrow$ & 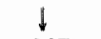 \\
\hline PNP/PMP-oxidase activity & ND & $\uparrow$ & ND & ND & ND & ND \\
\hline PLP-hydrolase activity & $\mathrm{ND}$ & r & - & - & - & $\Downarrow$ \\
\hline PL-oxidase activity & ND & $M-{ }_{i} F_{\uparrow}$ & ND & ND & ND & ND \\
\hline PL dehydrogenase activity & ND & $M \sim: F \uparrow$ & ND & ND & ND & ND \\
\hline
\end{tabular}

$\downarrow$ : significant age-related decrease; $\uparrow$ : significant age-related increase; $~:$ significant age-related change, but no overall increase or decrease noted: - no significant age-related change: ND: not determined. 
vitamin B-6 nutritional status, which requires reconsideration of the present RDA for vitamin B-6 at old age, on the other.

\section{References}

1. Vir SC, Love AHG. Vitamin B-6 status of the hospitalized aged. Am J Clin Nutr 1978;31: 138391.

2. Garry PJ, Goodwin JS, Huni WC, Hooper EM, Leonard AG. Nutritional status in in heallhy elderly population: dietary and supplemental intakes. Am J Clin Nutr 1982;36:319.31.

3. Guilland JC, Bereksi-Reguig B, Lequeu B, Moreau D, Kepping J, Richard D. Evaluation of pyridoxine intake and pyridoxine status among aged institutionalised people. Internat J Vit Nutr Res 1984:54:185-93.

4. Löwik MRH, Westenbrink S, Hulshof KFAM, Küstemaker C, Hermus. RJJ. Nutrition and aging: dictary intake of 'apparently healthy' elderly (Dutch Nutrition Surveillance System). I Am Coll Nutr 1989;8: 347-56.

5. Löwik MRH. Berg H van den, Westenbrink $S$, Wedel M, Schrijver J, Ockhuizen Th. Dose. response relationships regarding vitamin B-6 in elderly people: a nationwide nutritional survey (Dutch Nutritional Surveillance System). Am I Clin Nutr 1989;50:391-9.

6. Rose CS, György P, Butler M, Andres R, Norris AH, Shock NW, Tobin J, Brin M, Spiegel H. Age differences in vitamin B-6 status of 617 men. Am J Clin Nutr $1976: 29: 847-53$.

7. Hamfelt A, Söderhjelm L. Vitamin B-6 and aging. In: JE Leklem, RD Reynolds, Eds. Clinical and Physiological Applications of Vitamin B-6. Current Topics in Nutrition and Disease, Vol. 19. New York: Alan R. Liss, Inc. 1988: 95-107.

8. Hoorn RKJ, Flikweert JP, Westerink D. Vitamin B-1, B-2 and B-6 deficiencies in geriatric patients, measured by coenzyme stimulation of enzyme activities. Clin Chim Acta 1975;61:15162

9. Lee CM, Leklem JE. Differences in vitamin B-6 status indicator responses between young and middle-aged women fed constant diets with two levels of vitamin B-6. Am J Clin Nutr 1985;42: 226-34.

10. Kant $A K$, Moser-Veillon PB, Reynolds RD. Effect of age on changes in plasma, erythrocyte, and urinary B-6 vitamers after an oral vitamin B-6 load. Am J Clin Nutr 1988;48: 1284-90.

11. Leclerc J. Thiamine, riboflavine el vitamine B-6 tissulaires chez le rat agé. II. Influence d"une surcharge vitaminique administrée dans le régime sur l'excrétion des viltamines et sur leurs taux tissulaires. Ann Nutr Alim 1978;32: 753-63.

12. Fonda ML, Eggers DK, Mehta R. Vitamin B-6 metabolism in the livers of young adult and senescent mice. Exp Gerontol 1980:15: 457-63.

13. Fonda ML, Eggers DK. Vitamin B-6 metabolism in the blood of young adult and senescent mice. Exp Gerontol 1980;15:465-72.

14. Fonda ML. Eggers DK, Auerbach S, Fritsch L. Vitamin B-6 metabolism in the brains of young adult and senescent mice. Exp Gerontol 1980;15: 473-9.

15. Bieri JG, Stoewsand GS, Briggs GM, Phillips RW, Woodard JC, Knapka JJ, Report of the American Institute of Nutrition. Ad hoc committee on standards for nutritional studies. INutr 1977;107: 1340-8.

16. Berg H van den, Bogaards JJP. Vitamin B-6 metabolism in the pregnant rat: eflect of progesterone on the (re)distribution in maternal vitamin B-6 stores. J Nutr 1987;117: 1866-74.

17. Berg H van den, Bogaards JJP, Sinkeldam EJ, Schreurs WHP. Effect of different levels of vitamin $B-6$ in the diet of rats on the content of pyridoxamine-5'-phosphate and pyridoxal-5'.. phosphate in the liver. Internat J Vit Nutr Res $1982 ; 52$ : 407-16.

18. Lumeng L, Li T-K. Characterization of the pyridoxal-5'-phosphate and pyridoxamine -5'phosphate hydrolase activity in rat liver. Identity with alkaline phosphatase. J Biol Chem $1.975 ; 250: 8126-34$

19. Merrill AH, Henderson JM. Wang E, McDonald BW, Millikan WJ. Metabolism of vilamin B-6 by human liver. J Nutr 1984;114:1664-74.

20. Cori GT, Illingworth B, Keller PJ. Muscle phosphorylase. Meth Enzymol 1955:1: 200-5. 
21. Bayoumi RA Rosalki SB. Evaluation of methods of coenzyme activation of erytrhocyte enzymes for detection of deficiency of vitamins B-1, B-2 and B-6. Clin Chem 1976;22:327-35.

22. Schrijuer J, Schaik F van. Greef $I$ van der, Bos KD. Schreurs WHP. HPLC-analysis of xanthurenic acid and iss 8-methyl ether. In: HO Schlossberger, W Kochen. B Linzen, H Steinhart. Eds. Progress in Tryptophan and Serotonin Research. Berlin: Walter de Gruyter, Co. 1984: 71.5 .

23. Wolfson M. Kopple JD. The effects of vitamin B-6 deficiency in chronically azotemic and shamoperated rats. Kidney Int 1987:32: \$1.62-6.

24. Lumeng L. LiT-K. Mammalian vitamin B-6 metabolism: regulatory role of protein-binding and the hydrolysis of pyridoval $-5^{5}$ phosphate in storage and transport. In: G.P. Tryfiates, Ed. Vitamin B-6 Metabolism and Role in Growth. Westport. Conn: Food Nutrition Press, Inc. 1980:27.52.

25. Henderson LM. Vitamin B-6. In: RE Olson, HP Broquist, CO Chichester, WJ Darby, AC Kolbey Jr., RM Stalvey, editorial committex. Present Knowledge in Nutrition, 5th Ed. Washington DC: The Nutrient Foundation 1984:303-317.

26. Chandr, RK, Au B, Heresi $\mathrm{C}$. Single nutrient deficiency and cell-mediated immune responses. II. Pyridoxine. Nutr Res 1981;1:101-6.

27. Anderson BB, Newmark PA, Rawlins M, Green R. Plasma binding of vitamin B-6 compounds. Nature 1974:250:502-4.

28. Lumeng L, Brashear RE, Li T-K. Pyridoxal-5'-phosphate in plasma: source, protein-binding and cellular transport. J Lab Clin Med 1974:84: 334-43.

29. Cobum SP. White MP. Role of phosphatases in the regulation of vitamin B-6 metabolism in hypophosphatasia and other disorders. In: JE Leklem, RD Reynolds, Eds. Clinical and Physiological Applications of Vitamin B-6. Current Topics in Nutrition and Disease, Vol. 19. 1988: 65-93.

30. Bosron WF, Veitch RL, Lumeng $L$, Li T.K. Subcellular localization and identification of pyridoxal-5'-phosphate-binding protein in rat liver. J Biol Chem 1978;253: 1488-92.

31. Lui A. Lumeng $L, L i T \cdot K$. Stabidity of B-6 vitamers and location of pyridoxal-P hydrolase activity in isolated rat liver mitochondria. Fed Proc 1980;39:558 (abstract).

32. Tryfiates GP, Saus FL. Metabolism of pyridoxine in the liver of vitam in B-6 deficient rats. Biochim Biophys Acta 1976:451: 333-41.

33. Rose DP. The interaction between vilamin B-6 and hormones. Vitam Horm 1978:36:53-99

34. Chatteriec AK. Studies on the involvement of testicular hormone in the regulation of pyridoxal phosphate lormation by the kidney tissue. Endocrinology 1972;90:880-4.

35. Black AL, Guirard BM, Snell EE. Increased muscle phosphorylase in rats led high level of vitamin B-6. J Nuir 1977; 107: 1962-8.

36. Black AL, Cutrard BM, Snell EE. The behavior of muscle phosphorylase as a reservoir for vitamin B-6 in the rat. J Nutr 1978;108:670-7.

37. Beynon RJ, Fairhurst D. Cookson EJ. Turnover of skeletal muscle glycogen phosphorylase. Biomed Biochim Acta 1986;45:1619.25.

38. Mckay MJ. Bond J. Protein and amino acids. In: LH Chen. Ed. Nutritional Aspects of Aging. Vol. 1. Boca Raton Florida: C.R.C. Press, Inc, 1986: 173-94.

39. Tabot MC Miller LT, Kerkvliet NI. Pyridoxine supplementation: efiect on lymphocyte responses in elderly persons. Am J Clin Nutr 1987:46:659-64. 


\title{
Influence of age and sex on \\ vitamin B-6 vitamer distribution and on \\ vitamin B-6 metabolizing enzymes in Brown-Norway rats
}

Wilhelmina Bode, Johannes. A.J. Mocking and Henk van den Berg

\begin{abstract}
Aparently healthy male and female Brown-Norway rats, fed from weaning an openformula non-purified diet, containing $275 \mathrm{~g}$ crude protein and approximately $12 \mathrm{mg}$ available pyridoxine $\cdot \mathrm{HCl}$ per $\mathrm{kg}$, were obtained from different birth cohorts at different ages (from 6 to 38 months of age). Plasma pyridoxal-5"-phosphate (PLP) was highest in the youngest animals. Vitamin B-6 content of tissues examined showed different age-related patterns. Liver and heart vitamin B-6 content was highest in the oldest animals. Kidney and brain contents did not differ significantly between the youngest and the oldest animals, but were higher (kidney) or lower (brain) at intermediate ages. Total gastrocnemius muscle vitamin B-6 content was highest at 24-25 months and lowest at 36-38 months of age. Age-related differences in vitamin B-6 distribution were not related to concurrently observed differences in organ tissue vitamin B-6 metabolizing enzyme activities. Similarity in the age-related pattern of gastrocnemius muscle PLP concentration and glycogen phosphorylase activity suggests a role of protein-binding capacity in determining vitamin B-6 distribution. A low gastrocnemius muscle PLP concentration in combination with a low gastrocnemius muscle mass in the oldest animals was interpreted as to be indicative of a smaller vitamin B-6 body store in these animals than in younger ones. Observations reported here are in accordance with results of an earlier study on Wistar rats fed a different diet containing less vitamin B-6: at higher age vitamin B-6 is redistributed among various tissues.
\end{abstract}

\section{Introduction}

Several reports on nutrient intake and nutritional status indicate that elderly people have an impaired or diminished vitamin B-6 status compared with younger adults 
[1-7]. Observations from older studies on humans and animals suggest that agerelated changes in vitamin B-6 metabolism occur, which offer a possible explanation of the low vitamin B-6 status values observed at old age [8-12]. In a recent study on healthy aging male and female Wistar rats fed a vitamin B-6 adequate diet from weaning, vitamin B-6 vitamer distribution and vitamin B-6 metabolizing enzymes were evaluated [13]. As was observed in man, plasma pyridoxal-5'-phosphate (PLP) concentration, a widely used vitamin B-6 status indicator, decreased with age. Some organ tissues examined (gastrocnemius muscle, kidney and liver) also showed an agerelated decrease in vitamin B-6 content. In contrast, B-6 vitamer content was observed to increase with age in brain and heart tissue. It was concluded that the observed age-related changes in vitamin B-6 distribution were not causaliy related to the concurrently observed changes in vitamin B-6 metabolizing enzyme activities. Data on gastrocnemius muscle PLP content and glycogen phosphorylase (GP) activity suggested that age-related changes in protein metabolism are causally related to the observed differences in vitamin B-6 distribution.

In order to investigate whether the observed changes in the Wistar rat cohort study were truly attributable to aging, we measured parameters of vitamin B-6 metabolism in a different rat strain, Brown-Norway. In this report data on vitamin B-6 distribution are presented obtained from a cross-sectional study on BrownNorway rats, fed a different (open-formula non-purified instead of purified) but vitamin B-6 adequate diet from weaning up till 36-38 months of age. Results obtained are compared to those obtained in the Wistar rat cohort study (see [13] or Chapter 5 of this thesis).

\section{Materials and methods}

\section{Animals and experimental protocol}

The experimental protocol was approved by the Institute's Animal Care and Use Committee. Pigmented Brown-Norway rats (BN/BiRij) of different ages were obtained from the Institute for Experimental Gerontology TNO, Rijswijk, Netherlands. The rats had been bred under specific pathogen-free (SPF) conditions and maintained under clean conventional conditions at the Institute. Detailed information on husbandry of the animals is provided by Burek [14]. The animals were fed Standard Laboratory Rat Diet AM II (Hope Farms, Woerden, Netherlands), containing $272 \mathrm{~g}$ total protein and $15.2 \mathrm{mg}$ pyridoxine ( $\mathrm{PN}) \cdot \mathrm{HCl}$ per $\mathrm{kg}$. Of the $\mathrm{PN} \cdot \mathrm{HCl}$ present in the diet approximately $80 \%$ (or $12 \mathrm{mg} / \mathrm{kg}$ ) should be calculated as available to the animal (manufacturer's information). The experimental Brown-Norway rats were obtained from different birth cohorts. The animals studied were aged 6-7 months ( 6 males, 6 females), 24-25 months ( 6 males, 6 females), 30-31 months ( 5 males, 6 females) and 36-38 months ( 6 males, 2 females). 
General appearance and behavior of the animals were observed at arrival. The animals were sacrificed by exsanguination under diethyl ether anesthesia. Blood was collected from the abdominal aorta. Liver, heart, kidneys, brain and both gastrocnemius muscles were resected and weighed. All animals were subjected to gross post-mortem and histopathological examinations. Routine plasma clinicochemical parameters were measured to assess global health status and organ function. The animals included in the study were considered apparently healthy (without major lesions and with a clinico-chemical profile within reference range). Methods of sample preparation and sample analysis used have been described before [13].

\section{Statistical analysis}

Analysis of variance was performed on all data in a $2 \times 4$ factorial design with factors sex (male/female) and age (6-7, 24-25, 30-31 or 36-38 months) using the GENSTAT statistical package. A probability level $<0.05$ was considered statistically significant. For all paramet ars investigated the standard error of the difference between means (SED) is given in the tables and in the figure. T-values can be calculated by dividing the difference between two means by the corresponding SED.

\section{Results}

\section{General health status}

Body weights, absolute and relative organ weights and organ tissue protein concentrations are summarized in Table 1. Generally, body weights and organ weights were higher in the older animals, except for the gastrocnemius muscles. Relative muscle weight (percentage of body weight) was lowest for the oldest animals. Tissue protein level differed significantly among age groups for all organs examined. For brain and kidney the highest tissue protein levels were observed in the youngest age group, for heart tissue the youngest age group showed the lowest protein concentration.

Selected clinico-chemical parameters are given in Table 2. Both plasma albumin and total protein levels were higher for females than for males of the same age group and were lowest for the youngest age group. Plasma alkaline phosphatase (EC 3.1.3.1) activity was highest in male rats at an age of 6-7 months and in female rats at an age of 36-38 months. Erythrocyte glutathione reductase (EC 1.6.4.2) activity coefficient (EGR-AC) showed no values indicative of a low vitamin B-2 status in any age group. 
Table 1. Body weight, orgar weights and rissue protein content of male and female Brown-Norway rats at various ages.

\begin{tabular}{|c|c|c|c|c|c|c|c|c|c|}
\hline \multirow[t]{2}{*}{ Parameter } & \multirow[t]{2}{*}{ Sex } & \multicolumn{4}{|c|}{ Age (months) } & \multirow[t]{2}{*}{ SED } & \multicolumn{3}{|c|}{ Significance? } \\
\hline & & $6-7$ & $24-25$ & $30-31$ & $36-38$ & & age & $\sec x$ & age $\times$ sex \\
\hline \multirow{2}{*}{$\begin{array}{l}\text { Body weight } \\
(g)\end{array}$} & $M$ & 298 & 385 & 417 & 370 & \multirow[t]{2}{*}{13} & \multirow[t]{2}{*}{$<0,001$} & \multirow[t]{2}{*}{$<0.001$} & \multirow[t]{2}{*}{$<0.001$} \\
\hline & $\mathrm{F}$ & 168 & 189 & 205 & 210 & & & & \\
\hline \multicolumn{10}{|l|}{ Liver } \\
\hline \multirow{2}{*}{$\begin{array}{l}\text { Absolute wt } \\
(\mathrm{g})\end{array}$} & $\mathrm{M}$ & 8.67 & 10.18 & 10.84 & 10.67 & \multirow[t]{2}{*}{0.76} & \multirow[t]{2}{*}{$<0.001$} & \multirow[t]{2}{*}{$<0.001$} & \multirow[t]{2}{*}{ NS: } \\
\hline & $\mathrm{F}=$ & 5.19 & 6.20 & 7.52 & 7.67 & & & & \\
\hline \multirow{2}{*}{$\begin{array}{l}\text { Relative wt } \\
\text { (\% body wh) }\end{array}$} & M & 292 & 2.64 & 2.60 & 2.91 & \multirow[t]{2}{*}{0.27} & \multirow[t]{2}{*}{ NS } & \multirow[t]{2}{*}{$<0.001$} & \multirow[t]{2}{*}{ NS } \\
\hline & $\mathrm{F}$ & 3.08 & 3.28 & 3.73 & 3.65 & & & & \\
\hline \multirow{2}{*}{$\begin{array}{l}\text { Protein } \\
\text { (mg/g) }\end{array}$} & $M$ & 92.6 & 119.1 & 105.5 & 101.1 & \multirow[t]{2}{*}{4.4} & \multirow[t]{2}{*}{$<0.001$} & \multirow[t]{2}{*}{ NS } & 0.019 \\
\hline & $\mathrm{F}$ & 105.5 & 113.8 & 108.4 & 96.2 & & & & \\
\hline Gastrocnemius & scles & & & & & & & & \\
\hline Absolute wa: & $M$ & 3.97 & 4.24 & 3.88 & 2.41 & 0.38 & $<0.001$ & $<0.001$ & NS \\
\hline (g) & $F$ & 2.1 .4 & 2.31 & 2.15 & 1.77 & & & & \\
\hline Rélative wt & M & 1.34 & 1.10 & 0.92 & 0.67 & 0,13 & $<0.001$ & NS & NS \\
\hline (\% body wt) & $\mathrm{F}$ & 1.29 & 1.22 & 1.05 & 0.85 & & & & \\
\hline protein & $\mathrm{M}$ & 4.5 .443 & 4.5 .48 & 46.90 & 42.16 & 1.00 & $<0.001$ & 0.005 & NS \\
\hline$(\mathrm{mg} / \mathrm{g})$ & $F$ & 46.60 & 47.55 & 46.83 & 45.04 & & & & \\
\hline Heart & & & & & & & & & \\
\hline Absolute wh & $M$ & 0.935 & 1.368 & 1.406 & 1.611 & 0.075 & $<0.001$ & $<0.001$ & 0.034 \\
\hline$(\mathrm{g})$ & $F$ & 0.631 & 0.884 & 1.171 & 1.440 & & & & \\
\hline Relative wt & $\mathrm{M}$ & 0.315 & 0.355 & 0.340 & 0.435 & 0.026 & $<0.001$ & $<0.001$ & $<0.001$ \\
\hline (\% bodly wit) & $F$ & 0.374 & 0.468 & 0.574 & 0.687 & & & & \\
\hline Protein & $\mathrm{M}$ & 39.3 & 58.5 & 61.4 & 59.6 & 3.3 & $<0.001$ & NS & 0.001 \\
\hline$(\mathrm{mg} g \mathrm{~g})$ & $\mathrm{F}$ & 27.7 & 59.9 & 67.1 & 65.9 & & & & \\
\hline Brain & & & & & & & & & \\
\hline Absolute wt: & $M$ & 2.011 & 2.149 & 2.199 & 2.164 & 0.028 & $<0.001$ & $<0.001$ & NS \\
\hline (g) & $F$ & 1.801 & 1.926 & 1.932 & 1.888 & & & & \\
\hline Relative wt & M & 0.677 & 0.558 & 0.573 & 0.588 & 0.035 & $<0.001$ & $<0.001$ & 0.043 \\
\hline (\% body wl) & $\mathrm{F}$ & 1.073 & 1.019 & 0.945 & 0.901 & & & & \\
\hline Protein & M & 49.1 & 37.6 & 37.5 & 36.6 & 1.7 & $<0.001$ & NS & NS \\
\hline$(\mathrm{mg} / \mathrm{g})$ & $F$ & 49.1 & 37.6 & 37.5 & 36.6 & & & & \\
\hline Kidneys & & & & & & & & & \\
\hline Absolute wi & $\mathrm{M}$ & 1.606 & 2.016 & 2.252 & 2.306 & 0.084 & $<0.001$ & $<0.001$ & NS \\
\hline (g) & F & 1.016 & 1.390 & 1.462 & 1.581 & & & & \\
\hline Relative wt & $\mathrm{M}$ & 0.540 & 0.523 & 0.542 & 0.623 & 0.020 & $<0.001$ & $<0.001$ & $<0.001$ \\
\hline (\% body wi) & $\mathrm{F}$ & 0.602 & 0.736 & 0.71 .5 & 0.752 & & & & \\
\hline Protein & $\mathrm{M}$ & 121.0 & 98.5 & 82.5 & 76.7 & 8.8 & $<0.001$ & NS & NS \\
\hline$(\mathrm{m} / \mathrm{g})$ & $\mathrm{F}$ & 98.6 & 92.1 & 85.1 & 80.6 & & & & \\
\hline
\end{tabular}

1 SED, standard error of difference; NS, not significant.

ANOVA using factors age $(6-7,24-25,30-31$, and $36-38$ months) and sex (male female).

\section{Vitamin B-6 status}

Plasma PLP concentrations, erythrocyte aspartate aminotransferase (EC 2.6.1.1) activities (EASAT) and EASAT-AC values are summarized in Table 3. Plasma PLP 
concentrations were highest in the youngest animals, intermediate at 2425 months of age and lowest at older ages. Female rats showed higher plasma PLP levels and higher EASAT activities than males in the same age group.

Table 2. Plasma dinical chemistry and blood measurements in male and female Brown-Norway rats at various ages.

\begin{tabular}{|c|c|c|c|c|c|c|c|c|c|}
\hline \multirow[t]{2}{*}{ Pamater } & \multirow[t]{2}{*}{ Sex } & \multicolumn{4}{|c|}{ Age (months) } & \multirow[t]{2}{*}{ SED } & \multicolumn{3}{|c|}{ Significance ? } \\
\hline & & $6-7$ & $24-25$ & $30-31$ & $36-38$ & & $a g$ & $\operatorname{sex}$ & $\operatorname{age} \times \mathrm{se} \times$ \\
\hline \multicolumn{10}{|l|}{ Plasmana } \\
\hline Albumin & M & 30.9 & 35.4 & 34.4 & 31.5 & 1.3 & $<0.001$ & $<0.001$ & 0.013 \\
\hline$(g / 1)$ & $\mathbf{F}$ & 32.9 & 37.9 & 40.9 & 38.4 & & & & \\
\hline Total protein & $M$ & 59.2 & 690 & 68.2 & 64.9 & 2.1 & $<0.001$ & $<0.001$ & $N S !$ \\
\hline$(\mathrm{g} / 1)$ & $F$ & 60.0 & 70.2 & 75.3 & 72.5 & & & & \\
\hline Alkaline phos- & $\mathbb{M}$ & 96.9 & 77.6 & 74.1 & 65.6 & 6.8 & 0.010 & NS & 0.004 \\
\hline phatase (U/) & $F$ & 75.6 & 70.2 & 62.4 & 834 & & & & \\
\hline \multicolumn{10}{|l|}{ Blood } \\
\hline Hernoglobin & $\mathrm{M}$ & 7.68 & 8.62 & 833 & nud" & 0.43 & NS & NS & NS \\
\hline (mmol/l) & $\mathbb{E}$ & 8.18 & 8.23 & 8.25 & nd & & & & \\
\hline Henatocrit & $M$ & 0.389 & 0.433 & 0.418 & nd. & 0.022 & NS & NS & NS \\
\hline$(1 /)$ & $\sqrt{10}$ & 0.418 & 0.408 & 0.430 & $\mathrm{nd}$ & & & & \\
\hline \multicolumn{10}{|l|}{ Erythocytes } \\
\hline \multirow[t]{2}{*}{$\mathrm{EGR}-\mathrm{AC}^{1}$} & $M$ & 1.21 & 1.36 & 1.04 & 1.18 & 0.08 & 0.002 & NS & $\mathrm{NSS}$ \\
\hline & $F$ & 1.23 & 1.18 & 1.01 & 1.06 & & & & \\
\hline
\end{tabular}

${ }_{1}$ SED, standard error of difference; NS, not significant; nd, not determined; EGR-AC, erythrocyte glutathione reductase (EC 1.6.4.2) activity coefficient.

${ }^{2}$ ANOVA using factors age $(6-7,24-25,30-31$, and $36-38$ months) and sex (malle, female).

Table 3. Vitamin B-6 status parameters of male and female Brown-Norway rats at various ages.

\begin{tabular}{|c|c|c|c|c|c|c|c|c|c|}
\hline \multirow[t]{2}{*}{ Paraneter } & \multirow[t]{2}{*}{$\operatorname{Sex}$} & \multicolumn{4}{|c|}{ Age (months) } & \multirow[t]{2}{*}{$S E D^{\prime}$} & \multicolumn{3}{|c|}{ Significance 2} \\
\hline & & $6-7$ & $24-25$ & $30-31$ & $36-38$ & & ane & $\operatorname{sex}$ & $\operatorname{agc} \times \operatorname{sex}$ \\
\hline \multicolumn{10}{|l|}{ Plasma } \\
\hline PLP & $\mathrm{M}$ & 725 & 567 & $43 \pi$ & 483 & 56 & $<0.001$ & $<0.001$ & NSI \\
\hline (nnod/h) & $\mathrm{F}$ & 838 & 790 & 551 & 576 & & & & \\
\hline \multicolumn{10}{|l|}{ Erythroctes } \\
\hline ASAT: & $\mathrm{M}$ & 443 & 431 & 344 & 432 & 45 & 0,004 & $<0.001$ & NS \\
\hline (U/mmol Hb) & $F$ & 480 & 523 & 428 & 584 & & & & \\
\hline \multirow[t]{2}{*}{ ASAT-AC: } & $M$ & 1.13 & 1.15 & 1.13 & 1.11 & 0.02 & NS & $\mathrm{NS}$ & NS \\
\hline & $\mathrm{F}$ & 1.16 & 1.13 & 1.14 & 1.14 & & & & \\
\hline
\end{tabular}

1. SED, standard error of difference; NS, not significant; ASAT, aspartate aminotransferase (EC 2.6.1.1): ASAT-AC, aspartate aminotransferase activity coefficient.

${ }^{2}$ ANOVA using factors age $(6-7,24-25,30-31$, and $36-38$ months) and sex (male female). 
Table 4. Organ PLP and PMP concentrations of male and female Brown-Norway rats all various ages.

\begin{tabular}{|c|c|c|c|c|c|c|c|c|c|}
\hline \multirow[t]{2}{*}{ Parameter } & \multirow[t]{2}{*}{ Set } & \multicolumn{4}{|c|}{ Age (moniss) } & \multirow[t]{2}{*}{$S E D^{1}$} & \multicolumn{3}{|c|}{ Significance } \\
\hline & & $6-7$ & $24-25$ & $30-31$ & $36-38$ & & age & $\operatorname{sex}$ & age $\times$ sex \\
\hline \multicolumn{10}{|l|}{ PLP (mholll) } \\
\hline \multirow[t]{2}{*}{ Liver } & $M$ & 28.2 & 24.8 & 23.3 & 24.4 & 1.6 & $<0.001$ & NS ${ }^{\prime}$ & 0.004 \\
\hline & FF & 34.8 & 22.7 & 23.4 & 26.0 & & & & \\
\hline \multirow{4}{*}{$\begin{array}{l}\text { Gastrocnemius } \\
\text { muscle } \\
\text { Heart }\end{array}$} & $\mathrm{M}$ & 21.3 & 30.3 & 21.2 & 14.9 & 1.3 & $<0.001$ & NS & $<0.001$ \\
\hline & F & 21.5 & 28.0 & 20.1 & 22.0 & & & & \\
\hline & $M$ & 8.05 & 7.45 & 5.70 & 5.37 & 0.44 & $<0.001$ & NS & NS \\
\hline & $\mathrm{F}$ & 8.50 & 7.09 & 5.31 & 4.68 & & & & \\
\hline \multirow[t]{2}{*}{ Braing } & $M$ & 5.46 & 3.40 & 3.76 & 5.25 & 0.61 & $<0.001$ & NS & NS \\
\hline & $F$ & 5.52 & 3.52 & 4.04 & 4.63 & & & & \\
\hline \multirow[t]{2}{*}{ Kidney } & $\mathbb{M}$ & 9.52 & 10.65 & 8.24 & 6.83 & 0.89 & $<0.001$ & NS & NS \\
\hline & $\mathbb{F}$ & 10.67 & 11.59 & 8.22 & 4.74 & & & & \\
\hline \multicolumn{10}{|l|}{ PMP (mmolll) } \\
\hline \multirow[t]{2}{*}{ Liver } & $M$ & 19.6 & 118.7 & 18.5 & 21.6 & 1.7 & NS & NS & NS \\
\hline & $\mathrm{F}$ & 19.4 & 18.1 & 20.9 & 18.1 & & & & \\
\hline \multirow{2}{*}{$\begin{array}{l}\text { Gastrocnemius } \\
\text { muscle }\end{array}$} & $M$ & 3.72 & 4.63 & 5.74 & 4.66 & 0.52 & $<0.001$ & $<0.001$ & $<0.001$ \\
\hline & $\mathrm{F}$ & 3.27 & 6.08 & 5.74 & 7.83 & & & & \\
\hline \multirow[t]{2}{*}{ Heari } & $M$ & 17.84 & 15.61 & 13.97 & 1.3 .76 & 0.76 & $<0.001$ & NS & NS \\
\hline & $\mathrm{F}$ & 17.58 & 16.41 & 13.34 & 12.48 & & & & \\
\hline \multirow[t]{2}{*}{ Brain } & $M$ & 8.75 & 4.55 & 5.06 & 7.64 & $0.9 \|$ & $<0.001$ & NS & NS \\
\hline & $\mathrm{F}$ & 8.61 & 4.49 & 5.47 & 5.73 & & & & \\
\hline \multirow[t]{2}{*}{ Kidney } & $\mathrm{M}$ & 19.2 & 13.0 & 16.0 & 11.2 & 1.8 & 0.001 & NS & NS \\
\hline & $\mathrm{F}$ & 16.5 & 14.1 & 13.9 & 13.5 & & & & \\
\hline
\end{tabular}

1 SED, standard error of difference; NS, not significant.

2 ANOVA using factors age $(6-7,24-25,30-31$, and $36-38$ months) and sex (male, female).

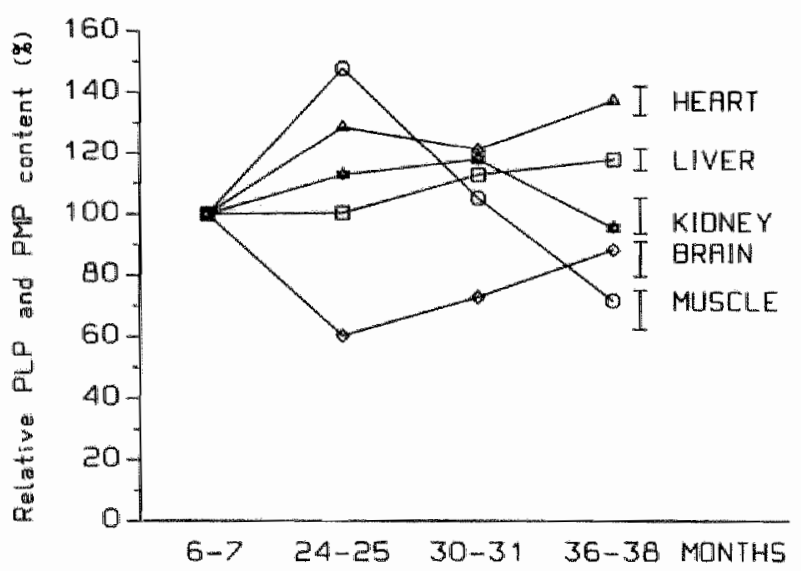

Figure 1. Relative changes in total organ PLP and PMP content (calculated as [concentration of PLP + PMPI X organ weight) of male and female Brown-Norway rats combined. Value at age 6-7 months is set at 1.00\%. SED for each organ is indicated by vertical bar. 
Table 5. Gastrocnemius muscle GP activity of male and female Brown-Norway rats at vanous ages.

\begin{tabular}{|c|c|c|c|c|c|c|c|c|c|}
\hline \multirow[t]{2}{*}{ Parameter } & \multirow[t]{2}{*}{ Sex } & \multicolumn{4}{|c|}{ Age (months) } & \multirow[t]{2}{*}{ SED" } & \multicolumn{3}{|c|}{ Significance } \\
\hline & & $6-7$ & $24-25$ & $30-31$ & $36-38$ & & $\mathrm{agc}$ & sax & $\mathrm{age} \times \mathrm{sex}$ \\
\hline Total GP & M & 71.6 & 117.2 & 1125 & 67.2 & 8.9 & $<0.001$ & 0.006 & NS: \\
\hline $\begin{array}{l}\text { (nmol/min per } \\
\text { protein) }\end{array}$ & $\mathbf{F}$ & 95.0 & 115.0 & 115.3 & 95.2 & & & & \\
\hline$G \mathrm{P}-\mathrm{ACl}$ & $\mathrm{M}$ & 0.999 & 0.993 & 1,000 & 1.004 & 0.021 & NS & NS & NS \\
\hline
\end{tabular}

: SED, standard error of difference; NS, not significant; GP, glycogen phosphorylase (EC 2.4.1.1) $a+b$; GP -AC, glycogen phosphorylase activity coefficient.

2. ANOVA using factors age $(6-7,24-25,30-31$, and $36-38$ months) and sex (male, femate).

Table 6. Organ vitamin B-6 metabolizing enzyme activities of male and female Brown-Norway rats at various ages.

\begin{tabular}{|c|c|c|c|c|c|c|c|c|c|}
\hline \multirow[t]{2}{*}{ Parameter } & \multirow[t]{2}{*}{$\operatorname{Sex}$} & \multicolumn{4}{|c|}{ Age (months) } & \multirow[t]{2}{*}{$\mathrm{SED}$} & \multicolumn{3}{|c|}{ Significance: } \\
\hline & & $6-7$ & $24-25$ & $30-31$ & $36-38$ & & age & $\mathrm{Sex}$ & $\operatorname{agc} \times x \mathrm{sex}$ \\
\hline \multicolumn{10}{|c|}{ PL-kinase activity (nmolih per mg protein) } \\
\hline \multirow[t]{2}{*}{$\operatorname{Liver}(\mathrm{pH} 7)$} & $\mathrm{M}$ & 2.69 & 1.61 & 1.66 & 3.00 & 0.57 & 0.022 & $<0.001$ & 0.023 \\
\hline & $\mathbb{F}$ & 7.85 & 7.11 & 6.30 & 6.06 & & & & \\
\hline \multirow{2}{*}{$\begin{array}{l}\text { Gistrocmenius } \\
\text { nuscle (pH 9) }\end{array}$} & $M$ & 0.53 & 0.78 & 0.88 & 1.10 & 0.20 & 0.035 & $\mathrm{NS}^{1}$ & NS \\
\hline & $F$ & 0.48 & 0.81 & 0.90 & 0.59 & & & & \\
\hline \multirow[t]{2}{*}{ Heart $(p H 9)$} & $\mathbb{M}$ & 1.72 & 0.92 & 0.69 & 0.74 & 0.19 & $<0.001$ & $<0.001$ & 0.001 \\
\hline & $\mathrm{F}$ & 2.74 & 1.34 & 0.72 & 0.71 & & & & \\
\hline \multirow[t]{2}{*}{ Brain (pH 7) } & $\mathbb{M}$ & 11.6 & 19.3 & 19.4 & 18.5 & 1. 1 & $<0.001$ & NS & NS \\
\hline & $\mathrm{F}$ & 11.5 & 18.5 & 19.6 & 20.7 & & & & \\
\hline \multirow[t]{2}{*}{ Kidney (pH 7) } & M & 12.61 & 10.44 & 12.22 & 13.19 & 0.77 & NS & 0.014 & 0.006 \\
\hline & $F$ & 11.66 & 11.50 & 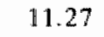 & 10.06 & & & & \\
\hline \multirow{2}{*}{$\begin{array}{l}\text { Erythrocytes } \\
(\mathrm{pH} 7)\end{array}$} & M & 5.72 & 3.29 & 3.16 & 4.50 & 0.66 & $<0.001$ & 0.017 & NS \\
\hline & $F$ & 6.13 & 3.84 & 4.33 & 5.73 & & & & \\
\hline \multicolumn{10}{|c|}{ PLP-hydrolase cactivity (romolh per mg protein) } \\
\hline \multirow[t]{2}{*}{ Liver } & $\mathbb{M}$ & 3.44 & 3.79 & 3.73 & 422 & 0.42 & $<0.001$ & NS & NS \\
\hline & $\mathrm{F}$ & 2.70 & 4.22 & 3.66 & 4.74 & & & & \\
\hline \multirow{4}{*}{$\begin{array}{l}\text { Gastrocnemat } \\
\text { musche } \\
\text { Heart }\end{array}$} & M & 0.83 & 1.03 & 1.44 & 2.33 & 0.25 & $<0.001$ & MS & $\mathrm{NS}$ \\
\hline & $\mathrm{F}$ & 0.86 & 1.27 & 1.29 & 1.59 & & & & \\
\hline & M & 7.05 & 4.75 & 6.66 & 5.76 & 0.64 & $<0.001$ & MS & $<0.001$ \\
\hline & $\mathrm{F}$ & 9.64 & 5.55 & 5.58 & 4.86 & & & & \\
\hline \multirow[t]{2}{*}{ Brain } & M & 42.8 & 34,6 & 42.1 & 37.3 & 2.8 & 0.012 & MS & NS \\
\hline & F & 42.4 & 37.6 & 35.3 & 3.6 .1 & & & & \\
\hline \multirow[t]{2}{*}{ Kidney } & $M$ & 247 & 467 & 434 & 351 & 76 & $<0.001$ & 0.002 & NS \\
\hline & $F$ & 324 & 600 & 527 & 552 & & & & \\
\hline \multicolumn{10}{|c|}{ PMP-oxidase activity (rmolh per mg protein) } \\
\hline \multirow[t]{2}{*}{ Liver } & M & 4.66 & 3.79 & 4.00 & 4.59 & 0.22 & 0.004 & NS & 0.009 \\
\hline & $F^{*}$ & 4.03 & 4.28 & 4.14 & 4.57 & & & & \\
\hline
\end{tabular}

'SED, standard error of difference; NS, not significant.

ANOVA using factors age $(6-7,24-25,30-31$, and $36-38$ months) and sex (male female).

${ }^{3}$ Activity in nmol/h per $\mu$ mol $\mathrm{Hb}$. 
Data on organ tissue PLP and pyridoxamine-5'-phosphate (PMP) concentrations are given in Table 4 and Fig. 1. Age-related differences were significant for both PLP and PMP level in all tissues examined except for liver PMP (Table 4). Liver (PLP only), heart, brain and kidney (PLP and PMP) showed the highest concentrations at younger age. Muscle PMP concentration, on the other hand, was lowest in the youngest age group. Notable is the highest muscle PLP concentration observed in the group aged 24-25 months. Total organ PLP and PMP content was highest in the oldest animals for liver and theart (Fig. 1). Kidney and brain contents did not differ significantly between the youngest and the oldest age groups but were higher (kidney) or lower (brain) in the intermediate age groups. Total muscle PLP and PMP content showed another age-related trend and was highest at 24-25 months of age and lowest at $36-38$ months of age.

Observations on gastrocnemius muscle glycogen phosphorylase (GP; EC 2.4.1.1) activity are summarized in Table 5. GP was predominantly present as GP-b, with GP- $a$ accounting for less than 5\% of total GP activity (results not shown). Addition of PLP to the reaction mixture did not give rise to a significant increase in GP activity. Total GP activity was higher in female than in male gastrocnemius muscle. Highest GP activities were observed at an age of 24-25 months.

\section{Vitamin B-6 metabolism}

Activities of pyridoxal kinase (PL-kinase; EC 2.7.1.35), PLP-hydrolase (EC 3.1.3.1) and PMP-oxidase (EC 1.4.3.5) measured in various samples are summarized in Table 6. PL-kinase was measured at pH 7 in liver, brain, kidney and erythrocytes, at $\mathrm{pH} 9$ in gastrocnemius muscle and heart (at $\mathrm{pH} 7$, PL-kinase activity was below detection limit). Activities differed significantly among age groups for all enzymes and tissues examined. Clear age-related trends were observed for heart and erythrocyte PL-kinase and heart and brain PLP-hydrolase on the one hand (highest at youngest age) and for muscle and brain PL-kinase and liver, muscle and kidney PLP-hydrolase on the other (lowest at youngest age). Significant sex-related differences were found for some enzyme activities. Especially liver PL-kinase and kidney PLP-hydrolase were appreciably higher in female than in male rats.

\section{Discussion}

The Brown-Norway rats used in the experiment reported here differed from the Wistar rats used in an earlier experiment on several points, apart from the straindependent difference in pigmentation [13]. First, the Brown-Norway rats were obtained from different birth cohorts, whereas in the Wistar experiment one birth cohort was followed from weaning. This implicates that the Brown-Norway aging 
study was purely cross-sectional whereas the Wistar aging study was semilongitudinal. Second, the Brown-Nonway rats are small compared to age-matched Wistar rats. Relative organ weights (percent of body weight), however, are comparable for both strains except for a higher relative brain weight and a lower relative kidney weight in Brown-Norway than in Wistar rats. Third, the BrownNorway rats were fed a diet with a higher vitamin B-6 level and slightly higher protein level than the Wistar rats: approximately $12 \mathrm{mg} \mathrm{PN} \cdot \mathrm{HCl}$ and $275 \mathrm{~g}$ crude protein per $\mathrm{kg}$ versus $5.9 \pm 0.9 \mathrm{mg} \mathrm{PN} \cdot \mathrm{HCl}$ and $250 \mathrm{~g}$ casein per $\mathrm{kg}$, respectively. Furthermore, the Brown-Norway diet was less defined than the Wistar diet, being an open-formula non-purified diet instead of a purified diet.

\section{Comparison of Brown-Norway and Wistar rats}

The higher vitamin B-6 content of the Brown-Norway diet than the Wistar diet could result in higher B-6 vitamer concentrations in Brown-Norway than in Wistar rats. However, markedly higher concentrations in Brown-Norway than in Wistar rats were observed only for plasma PLP concentration at all ages (see Table 3 for BrownNorway data and Chapter 5 , Table 5 for Wistar data) and brain PLP and PMP levels at 6-7 months of age (see Table 6 for Brown-Norway data and Chapter 5, Table 9 for Wistar data). Despite similar gastrocnemius muscle PLP concentrations in both strains of rats, GP activity was markedly lower in Brown-Norway (Table 5) than in Wistar gastrocnemius muscle (Chapter 5, Table 7). This indicates a smaller percentage of total muscle PLP is present bound to GP in Brown-Norway than in Wistar rats.

Notable strain differences in vitamin B-6 metabolizing enzyme activities were observed for liver PL-kinase and PMP-oxidase activities (lower levels for BrownNorway than for Wistar for all age groups) and for kidney PL-kinase and PLP-hydrolase activities (lower values for Brown-Norway at younger ages, similar vallues at older ages) (see Table 6 for Brown-Norway data and Chapter 5, Tables 6 and 10 for Wistar liver and kidney data, respectively). Marked strain-related differences in liver and kidney vitamin B-6 vitamer concentrations, however, were not observed (see Table 4 for Brown-Norway data and Chapter 5, Tables 6 and 10 for Wistar liver and kidney data, respectively). Average brain PL-kinase activities were similar for both strains of rats, but age-related trends were opposite (see Table 6 for Brown-Norway data and Chapter 5, Table 9 for Wistar data). In BrownNorway rats PL-kinase activity was lowest in the youngest age group and higher in all olcler age groups, whereas Wistar rats showed an age-related decrease in brain PL-kinase activity. These strain-related differences in PL-kinase activity trends were not explanatory for the observed higher brain PLP and PMP levels in Brown-Norway rats at an age of 6 7 months (Table 4 ) than in age-matched Wistar rats (Chapter 5 , Table 9). 
Distribution of vitamin B-6 among the various organs examined was found to differ among age groups. A similar age-related pattern of vitamin B-6 distribution in BrownNorway (Tables 3 and 4) and Wistar rats (Chapter 5, Tables 5,7 and 8) was observed for plasma, gastrocnemius muscle and heart. Wistar rats showed an age-related decrease in plasma PLP level, an age-related increase in heart vitamin B-6 content and an age-related increase followed by a decrease in gastrocnemius vitamin B-6 content (Chapter 5, Fig. 2) [13], closely resembling the observations in BrownNorway rats reported here (Fig. 1). Differences between strains were observed for liver, kidney and brain vitamin B-6 content. Wistar liver showed no significant agerelated difference in total PLP and PMP content, whereas in Brown-Norway rats total content was slightly but significantly higher in the older rats than in rats aged of 6-7 months. Wistar rats showed a decrease in kidney total PLP and PMP content from the age of 19 months, Brown-Norway rats showed similar kidney B-6 vitamer content at an age of 6-7 months and at an age of 36-38 months, with slightly higher values in between. These differences between strains appear to be of minor relevance. Brain total PLP and PMP content showed an age-related increase in Wistar rats, whereas in Brown-Norway rats highest brain PLP and PMP content was observed in the youngest age group (6-7 months of age). Thus, contrary to Wistar rats, Brown-Norway brain vitamin B-6 vitamer content appears to decrease with age (followed by an increase). However, apart from the values at 6-7 months of age, brain PLP and PMP concentrations did not differ markedly between strains at older ages.

As was observed for Wistar rats, age-related differences in organ tissue PLP and/or PMP concentration appear to be unrelated to concurrently observed differences in organ tissue vitamin B-6 metabolizing enzyme activities. Also, the similar age-related differences in gastrocnemius muscle PLP concentration (Table 4) on the one hand and GP activity (Table 5) on the other again suggest that the low muscle PLP levels observed at old age could be related to age-related differences in protein-binding capacity. Furthermore, as in the Wistar rats, the low gastrocnemius muscle PLP concentrations (Table 4) combined with the low relative gastrocnemius muscle mass (Table 1) in the old Brown-Norway rats might be indicative of a smaller vitamin B-6 body store in old than in young rats. Generally speaking, the conclusions from the Wistar study are supported by the present findings for Brown-Norway rats.

\section{References}

1. Rose CS, Gyorgy P, Butler M. Andres R, Norris AH, Shock NW, Tobin J, Brin M, Spiegel H. Age differences in vitamin B-6 status of 617 men. Am J Clin Nutr 1976;29:847-53.

2. Vir SC. Love AHG. Vitamin B-6 status of the hospitalized aged. Am J Clin Nutr 1978;31: 1383-91.

3. Garry PJ, Goodwin JS. Hunt WC. Hooper EM. Leonard AG. Nutritional status in a healthy alderly population: dietary imtakes. Am J Clin Nutr 1982;36: 319-31. 
4. Guilland $\sqrt{ } \mathrm{C}$. Bereksi-Reguig B, Lequeu B, Moreau D, Klepping $J$ \& Richard D. Evaluation of pyridoxine intake and pyridoxine status among aged instintionalised people. Int J Vit Nutr Res 1984;54: 185-93.

5. Hamfelt A \& Söderhjelm L. Vitamin B-6 and aging. In: Leklem JE, Reynolds RD, eds. Clinical and Physiological Applications of Vitamin B-6. New York: Alan R. Liss, 1988: 95-107. (Current Topics in Nutrition and Disease 19.)

6. Lowik MRH, van den Berg H, Westenbrink S, Wedel M, Schrijver J, Ockhuizen Th. Doseresponse relationships regarding vitamin B-6 in elderly people: a nationwide nutritional survey (Dutch Nutritional Surveillance System). Am J Clin Nutr 1989;50:391-9.

7. Löwik MRH, Westenbrink S, Hulshof KFAM, Kistemaker C, Hermus RJJ. Nutrition and aging: dietary intake of "apparently healthy' elderly (Dutch Nutrition Surveillance System). IJ Am Coll Nutr 1989:8: 347-56.

8. Leclerc J. Thiamine, riboflavine et vitamine B-6 tissulaires chez le rat agé. II. Influence d'une surcharge vitaminique administrée dans le régime sur l"excrétion des vitamines et sur leurs taux tissulaires. Ann Nutr Alim 1978; 32: 753-63.

9. Fonda ML, Eggers DK, Mehta R. Vitamin B-6 metabolism in the livers of young adult and senescent mice. Exp Gerontol 1980;15: 457-63.

10. Fonda ML, Eggers DK. Vitamin B-6 metabolism in the blood of young adult and senescent mice. Exp Gerontol 1980; 15: 465-72.

11. Fonda ML, Eggers DK, Auerbach S, Fritsch L. Vitamin B-6 metabolism in the brains of young adult and senescent mice. Exp Gerontol 1980;15:473-9.

12. Lee $\mathrm{CM}$, Leklem JE. Differences in vitamin B-6 status indicator responses between young and middle-aged women fed constant diets with two levels of vitamin B-6. An J Clin Nutr 1985;42: 226-34.

13. Bode W, Mocking JAJ, van den Berg H. Influence of age and sex on vitamin B-6 vitamer distribution and on witamin B-6 metabolizing enzymes in Wistar rats. $J$ Nutr 1991;121:318.29.

14. Burek JD. Pathology of aging rats. West Palm Beach: C.R.C. Press, 1978. 



\section{Part III. Biokinetic approach of vitamin B-6 and aging}




\title{
Pyridoxal-5'-phosphate and pyridoxal biokinetics in aging Wistar rats
}

Wilhelmina Bode and Henk van den Berg

\begin{abstract}
Biokinetic parameters of plasma pyridoxal-5'-phosphate (PLP) and pyridoxal (PL) disposition were studied in male Wistar rats aged 8 and 27 months fed from weaning a purified diet containing $250 \mathrm{~g}$ casein and $6 \mathrm{mg}$ pyridoxine $\cdot \mathrm{HCl}$ per $\mathrm{kg}$. Baseline plasma PLP concentration was lower in the older animals $(514 \pm 56 \mathrm{nmol} / \mathrm{l}$ for young and $317 \pm 124 \mathrm{nmol} / 1$ for old animals), whereas baseline plasma PL concentration did not differ between age groups (average $235 \mathrm{nmol} / \mathrm{l}$ for both young and old animals). We hypothesized lower baseline plasma PLP in the older animals was caused by an increased PLP elimination rate, a decreased PLP synthesis rate, or a combination of these processes. Observations from earlier in vitro experiments suggest that age-related changes occur in vitamin B-6 metabolizing enzyme activities. In the in vivo experiments described here no age-related difference in plasma PLP elimination rate nor in plasma PLP synthesis rate was observed to explain the observed decrease in plasma PLP concentration with age.
\end{abstract}

\section{Introduction}

In many observational studies in elderly people a high incidence of (subclinical) biochemical vitamin B-6 deficiency has been found, based on a llow plasma pyridoxal5'-phosphate (PLP) level [1-3]. Low dietary vitamin B-6 intake could account for the higher prevalence of biochemical vitamin B-6 deficiency in the elderly |4-7|. However, in several studies $10-20 \%$ of the elderly did not respond to supplementation, which might indicate a change in vitamin B-6 metabolism with age $[4,6,8]$. Few human experimental studies have been performed, but some evidence of age-related changes in human vitamin B-6 metabolism has been reported $[9,10]$. Data on animal experiments are more abundant, also suggesting age-related changes in vitamin B-6 metabolism [1 $1-15]$. Significant age-related shifts in vitamin B-6 distribution among rat body compartments have been observed, with heart and brain tissue showing an increase and liver, kidney, gastrocnemius muscle and plasma showing a decrease with age [16]. In a recent study on normal control rats of 
different ages plasma PLP level was found to be not only lower but also more resistant to vitamin $\mathrm{B}-6$ depletion in older animals [17].

Evidence suggestive of age-related changes in vitamin B-6 metabolism obtained so far mainly consist of biochemical, i.e. in vitro, observations on enzyme activities in various (tissue) samples. One example is the observed age-related increase in serum alkaline phosphatase activity, which is inversely correlated to the concurrently observed age-related decrease in plasma PLP concentration (see e.g. [10]). Translation of enzyme activities measured in vitro in specific organ homogenates to the in vivo situation in the total intact organism is complicated, due to differences in reaction conditions, occurence of regulatory mechanisms, etc. To investigate agerelated changes of in wivo vitamin B-6 disposition, we used a biokinetic approach. The first hypothesis tested is, that the age-related decrease in rat plasma PLP level is caused by an increase of PLP elimination rate (increase of in vivo alkaline phosphatase activity). A second hypothesis, which was tested in the same experiment, is, that plasma PLP decreases with age because of an age-related decrease in PLP synthesis (decreased in vivo pyridoxal (PL) kinase activity). We therefore compared biokinetic parameters of both plasma PLP and PL in young fullgrown rats at an age of 8 months with those in old rats at an age of 27 months, the age of $50 \%$ mortality. Furthermore, physiological implications of biokinetic parameters found are discussed.

\section{Materials and methods}

\section{Animal handling}

Newly weaned male Wistar rats (Bor:WISW (SPF Cpb), $n=120$ ) were obtained from F. Winkelmann, Borche, FRG. All animals were fed a purified diet ad libitum, containing $250 \mathrm{~g}$ casein and $6 \mathrm{mg}$ pyridoxine $\cdot \mathrm{HCl}(\mathrm{PN})$ per $\mathrm{kg}$. The experimental diet and housing conditions have been described in detail before [16]. The experimentall protocol was approved by the Institute's Animal Care and Use Committee.

At an age of 8 and at an age of 27 months ten healthy animals were randomly selected for biokinetic experiments and housed individually in plastic cages with sawdust bedding. The animals were equipped with a permanent indwelling catheter in the right external jugular vein and were allowed at least one week of recovery. During the experiments plugging of catheters was observed in some animals. Complete data sets were collected from six rats in each age group.

\section{Experimental procedure}

During the experiment, exposure of PLP and pyridoxal (PL) solutions, blood and plasma to light was minimized. The day before dosing, blood from each animal was collected in vials containing $8 \%$ sodium-EDTA and centrifuged immediately at 
$2000 \mathrm{~g}$ and $4{ }^{\circ} \mathrm{C}$ for $20 \mathrm{~min}$. Plasma was transferred to another vial and stored at $-20^{\circ} \mathrm{C}$. On the day of the experiment the plasma was mixed with a solution containing an exactly known concentration of either PLP or PL ( $2 \mathrm{mg} P L P \cdot \mathrm{H}_{2} \mathrm{O}$ or $\mathrm{PL} \cdot \mathrm{HCl}$ per ml saline) at a ratio of $1: 1$. This mixture was incubated at $37{ }^{\circ} \mathrm{C}$ in the dark for $45 \mathrm{~min}$. At 08.00 the animals were dosed intravenously with $800 \mu \mathrm{l}$ of spiked plasma, each animal receiving its own plasma. $100 \mu \mathrm{l}$ of blood was collected in vials containing $8 \%$ sodium-EDTA immediately before dosing and at $15,30,45,60$, $90 \mathrm{~min}, 2,3,4,5,6,8,10,25$ and $33 \mathrm{~h}$ after dosing. Blood samples were stored at $0-4{ }^{\circ} \mathrm{C}$ in the dark and were centrifuged at $2000 \mathrm{~g}$ and $4{ }^{\circ} \mathrm{C}$ for 20 min within $4 \mathrm{~h}$. Plasma was transferred to another vial and stored at $-20^{\circ} \mathrm{C}$ until analysis. PLP was administered first, the second dose (PL) was administered after a one-week washout period.

\section{Analysis of samples}

Plasma was incubated with trichloroacetic acid (TCA) at $37^{\circ} \mathrm{C}$ for $30 \mathrm{~min}$ and centrifuged at $2000 \mathrm{~g}$ and $4{ }^{\circ} \mathrm{C}$ for $20 \mathrm{~min}$. The clear TCA extracts were used for both PLP and PL analysis. PLP concentration was measured by a modification of the L-tyrosine apodecarboxylase assay of Chabner and Livingstone [18]. PL concentration was measured by a modification of the HPLC method described by Schrijver et al. [19]. Analysis was performed in a room illuminated with yellow fluorescent light.

\section{Biokinetic analysis}

The observed plasma concentration-time curves were fitted with a standard nonlinear regression program (BMDP3R) using a biexponential function:

$$
C(t)=A_{b}+A_{1} \cdot \exp \left(-\lambda_{1} \cdot t\right)+A_{2} \cdot \exp \left(-\lambda_{2} \cdot t\right)
$$

$C(t)$ is plasma concentration at time $t$ after dosing, $A_{b}$ is baseline plasma concentration, $A_{1}$ and $A_{2}$ are the exponential constants, and $\lambda_{1}$ and $\lambda_{2}$ are the exponential coefficients. For all plasma concentration values a weighting factor equal to the inverse of the error variance was used in the curve fitting procedure. The exponential constants and the exponential coefficients derived through curvefitting were used to calculate various biokinetic parameters using well-established formulae $[20 \mid$. Subscripts PL or PLP denote whether parameters are descriptive of PL or PLP biokinetics. The area under the plasma concentration-time curve (AUC) was calculated as $\left(A_{1} / \lambda_{1}\right)+\left(A_{2} / \lambda_{2}\right)$. The area under the first-moment curve (AUMC) was calculated as $\left(\mathrm{A}_{1} / \lambda_{1}{ }^{2}\right)+\left(\mathrm{A}_{2} / \lambda_{2}{ }^{2}\right)$. Total plasma clearance $(\mathrm{Cl})$ was calculated as dose (D) divided by AUC. Mean residence time (MRT) was calculated as AUMC/AUC. Volume of the central compartment $\left(\mathrm{V}_{1}\right)$ was calculated as $\mathrm{D} /\left(\mathrm{A}_{1}+\mathrm{A}_{2}\right)$. Area-derived volume of distribution ( $\left.\mathrm{V}_{\text {area }}\right)$ was calculated as $\mathrm{D} /\left(\mathrm{AUC} \cdot \mathrm{x}_{2}\right) . \mathrm{D}, \mathrm{Cl}, \mathrm{V}_{1}$ and $\mathrm{V}_{\text {area }}$ were also calculated after correction 
for body weight (BW). AUC is proportional to the total amount of substance dosed into the biokinetic system, irrespective of the shape of the plasma concentration-time curve, as long as total plasma clearance is constant. With this proportionality between AUC and amount "the percentage of PL dosed phosphorylated to PLP, and the percentage of PLP dosed dephosphorylated to PL, can be estimated: by comparison of corresponding AUC-values (if necessary corrected for difference in dose size administered). The percentage of PL dose phosphorylated to PLP (F. PLPP) is thus calculated as:

\section{(AUC $P$ PP after PL dosing $/ A U C$ PLP after PLP dosing $) \cdot\left(D_{P L P} / D_{P L}\right) \cdot 100 \%$}

The percentage of PLP dose phosphorylated to PL $\left(\mathrm{F}_{\mathrm{PLP} \rightarrow \mathrm{PL}}\right)$ is calculated in an analogous way:

$\left(\right.$ AUC $_{\mathrm{PL}}$ after PLP dosing $/ \mathrm{AUC}_{\mathrm{PL}}$ after PL dosing $) \cdot\left(\mathrm{D}_{\mathrm{PL}} / \mathrm{D}_{\mathrm{PLP}}\right) \cdot 100 \%$

\section{Statistical analysis}

Analysis of variance (ANOVA) was performed on the biokinetic parameters calculated for the two age groups using the GENSTAT statistical package. A probability level ( $P$ vallue) $<0.05$ was considered significant. Data were expressed as mean \pm standard deviation (SD).

\section{Results}

The animals randomly selected from the cohort for the biokinetic study showed a weight difference between age groups ( $387 \pm 31 \mathrm{~g}$ for young and $442 \pm 36 \mathrm{~g}$ for old animals; $P=0.014$ ). Food intake did not differ; PN intake calculated from food consumption data was approximately $400 \mathrm{nmol} /$ day, which is considered adequate for the animals studied [21].

No significant day-to-day variation was noted for basal PLP or PL level in plasma (data not shown). Basal plasma PLP level was not influenced by time point of sampling (data not shown). As basal PL level in plasma collected at different times was measured in pooled samples only, no definitive conclusion could be drawn from these limited data.

Fig. 1 shows the average plasma PLP and PL response after dosing of PLP, and Fig. 2 shows the response after dosing of PL to the same animais. No differences in curve shape were noted between young and old animals but, on average, PLP curves were shifted to a lower concentration for the old rats compared to the young ones.

Results of biokinetic analysis of each separate curve are shown in Tables 1 and 2 (biokinetic parameters of PLP and PL, respectively). PLP and PL dose in $\mu m o l / k g$ BW differed significantly between age groups due to the fact that 

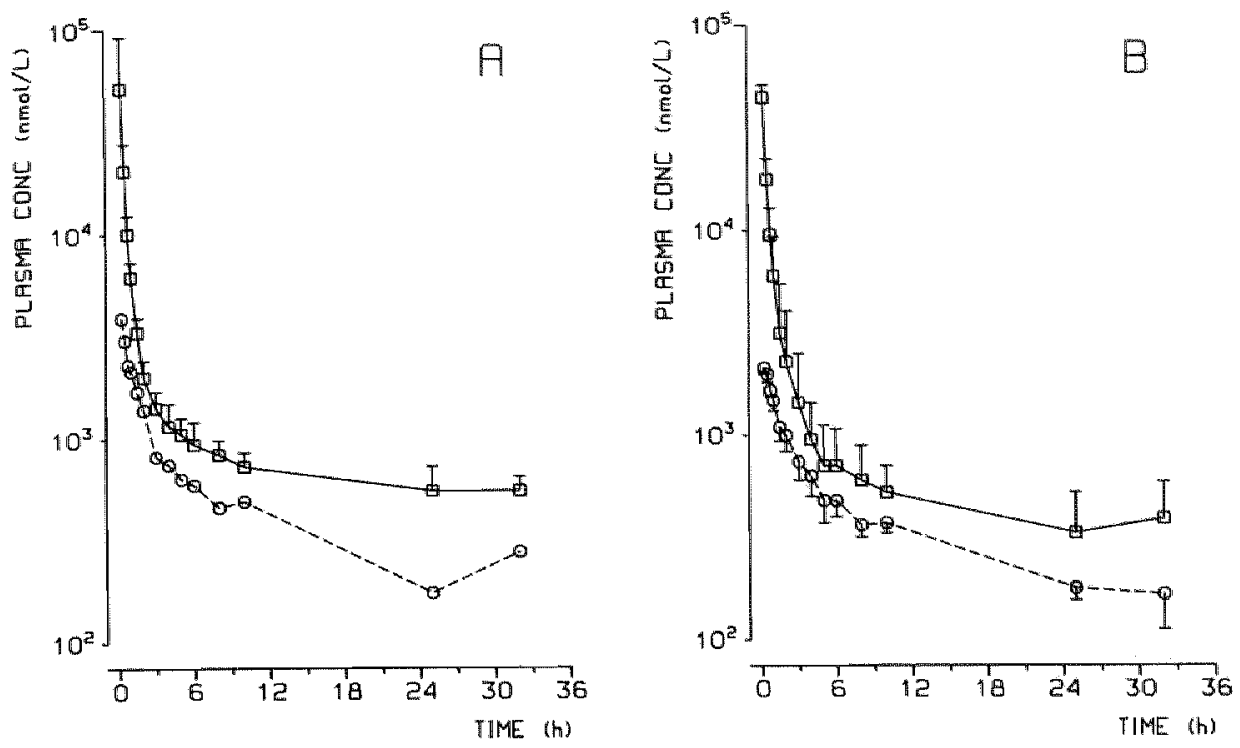

Fig. 1. Plasma PLP and PL response (mean \# SD) after an intravenous dose of PLP. A, young animals; B, old animals; squares, PLP concentration; circles, PL concentration. Plasma PL response in young aninals wass measured in pooled samples.
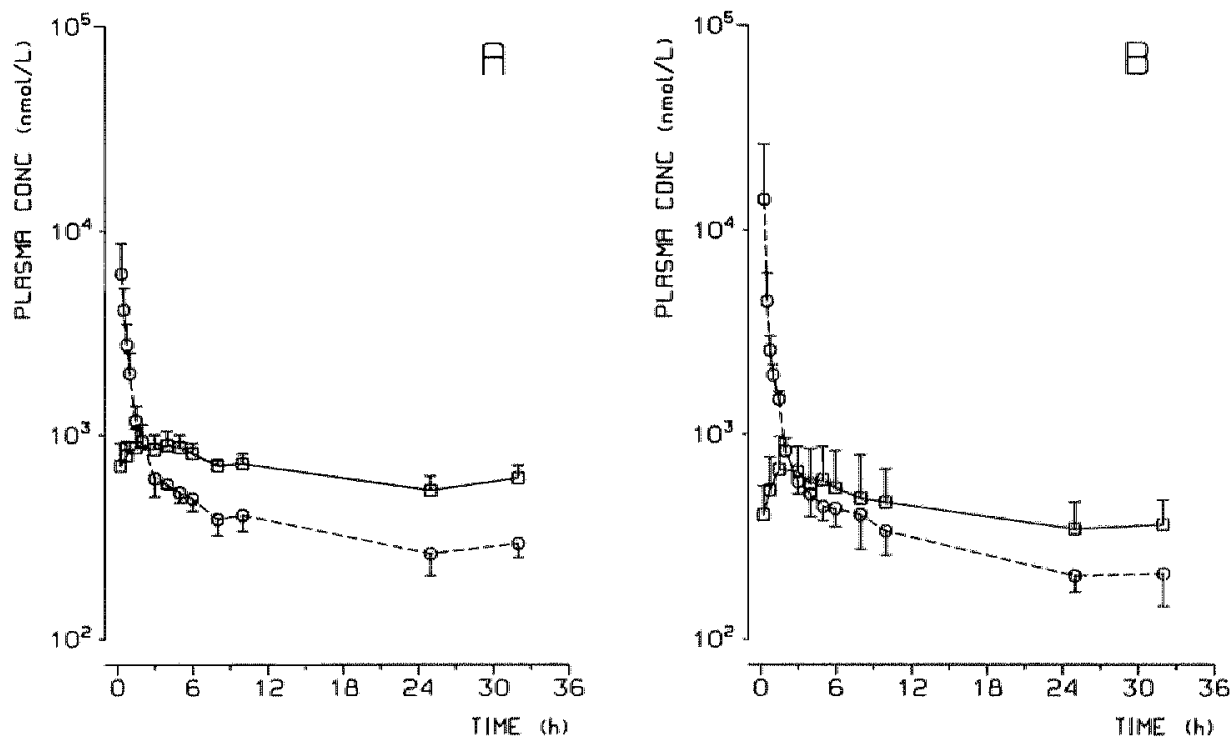

Fig. 2. Plasma PLP and PL response (mean $\pm S D$ ) after an intravenous dose of PL. A, young animals; B, old animals; squares, PLP concentration; circles, PL concentration. For the sake of clarity some PLP concentrations measured before $t=3 \mathrm{~h}$ after dosing have been omitted. 
Table 1. Biokinetic parameters descriptive of PLP disposition (mean $\pm \mathrm{SD} ; n=6$ ).

\begin{tabular}{|c|c|c|c|c|}
\hline Parameter & Unit & Young & Old & $P$ \\
\hline$D_{\mathbb{P L P}}$ & $\mu \mathrm{mol} / \mathrm{kg} \mathrm{BW}$ & $7.85=0.70$ & $6.88 \pm 0.59$ & 0.022 \\
\hline Batsal plasma PLP & nmol/1 & $514 \pm 56$ & $317 \pm 124$ & 0.005 \\
\hline $\mathrm{Cl}_{\text {PLP }}$ & $\begin{array}{l}\text { I/h } \\
\text { I/(h.kgBW) }\end{array}$ & $\begin{array}{l}0.091 \pm 0.018 \\
0.240 \pm 0.051\end{array}$ & $\begin{array}{l}0.108 \pm 0.030 \\
0.247 \pm 0.073\end{array}$ & $\begin{array}{l}\text { NS: } \\
\text { NS }\end{array}$ \\
\hline $\begin{array}{l}\lambda_{1} \text { curwe PLP after DPLP } \\
\lambda_{2} \text { curve PLP after DPLP }\end{array}$ & $\begin{array}{l}1 / \mathrm{h} \\
1 / \mathrm{h}\end{array}$ & $\begin{aligned} 3.22 & \pm 0.28 \\
0.338 & \pm 0.138\end{aligned}$ & $\begin{aligned} 3.42 & \pm 0.75 \\
0.386 & \pm 0.150\end{aligned}$ & $\begin{array}{l}\text { NS } \\
\text { NS }\end{array}$ \\
\hline $\mathrm{V}_{1, \mathrm{PLP}}$ & $\begin{array}{l}\text { I } \\
\text { I/kg BW }\end{array}$ & $\begin{array}{l}0.037 \pm 0.007 \\
0.096 \pm 0.022\end{array}$ & $\begin{array}{l}0.045 \pm 0.016 \\
0.102 \pm 0.038\end{array}$ & $\begin{array}{l}\text { NS } \\
\text { NS }\end{array}$ \\
\hline$V_{\text {area }}$ PLP & I/kg BW & $\begin{array}{c}0.289 \pm 0.072 \\
0.76 \pm 0.21\end{array}$ & $\begin{array}{c}0.348 \pm 0.217 \\
0.82 \pm 0.57\end{array}$ & $\begin{array}{l}\text { NS } \\
\text { NS }\end{array}$ \\
\hline $\begin{array}{l}\text { MRTPLP after DPLP } \\
\text { MRT PLP after }{ }^{D} \text { PL }\end{array}$ & $\begin{array}{l}\mathrm{h} \\
\mathrm{h}\end{array}$ & $\begin{array}{l}1.03 \pm 0.24 \\
11.5 \pm 7.3\end{array}$ & $\begin{aligned} 1.04 & \pm 0.32 \\
5.6 & \pm 3.1\end{aligned}$ & $\begin{array}{l}\text { NS } \\
\text { NS }\end{array}$ \\
\hline FPL $\rightarrow$ PLP & $\%$ & $16.7 \pm 11.4$ & $6.7 \pm 3.1$ & TR ${ }^{1}$ \\
\hline
\end{tabular}

NS, not significant; TR, trend, $P<0.1$.

Table 2. Biokinetic parameters descriptive of PL disposition (mean $\pm \mathrm{SD} ; n=6$ ).

\begin{tabular}{|c|c|c|c|c|}
\hline Parameter & Unit & Young & Old & $P$ \\
\hline $\begin{array}{l}\text { DPL } \\
\text { Basal plasma PL }\end{array}$ & $\begin{array}{l}\mu \mathrm{mol} / \mathrm{kg} \mathrm{BW} \\
\mathrm{nmol} / \mathrm{l}\end{array}$ & $\begin{aligned} 10.21 & \pm 0.92 \\
235 & \pm 63\end{aligned}$ & $\begin{array}{l}8.86 \pm 0.76 \\
235 \pm 5\end{array}$ & $\begin{array}{r}0.015 \\
N^{1}\end{array}$ \\
\hline $\mathrm{ClPL}_{\mathrm{P}}$ & $\begin{array}{l}\text { l/h } \\
1 /(\mathrm{h} \cdot \mathrm{kg} B W)\end{array}$ & $\begin{array}{c}0.503 \pm 0.085 \\
1.30 \pm 0.15\end{array}$ & $\begin{aligned} 0.589 & \pm 0.204 \\
1.34 & =0.58\end{aligned}$ & $\begin{array}{l}\text { NS } \\
\text { NS }\end{array}$ \\
\hline $\begin{array}{l}\lambda_{1} \text { curve } \mathrm{PL} \text { after } \mathrm{DPL} \\
\lambda_{2} \text { curve } \mathrm{PL} \text { afici } \mathrm{PPL}\end{array}$ & $\begin{array}{l}1 / \mathrm{h} \\
1 / \mathrm{h}\end{array}$ & $\begin{aligned} 2.119 & \pm 0.26 \\
0.240 & =0.105\end{aligned}$ & $\begin{aligned} 1.44 & \pm 0.41 \\
0.166 & \pm 0.047\end{aligned}$ & $\begin{array}{c}0.003 \\
\text { NS }\end{array}$ \\
\hline$V_{1, P L}$ & $\begin{array}{l}1 \\
\mathrm{~V} / \mathrm{kg} \mathrm{BW}\end{array}$ & $\begin{array}{c}0.440 \pm 0.066 \\
1.14 \pm 0.11\end{array}$ & $\begin{array}{c}0.674 \pm 0.277 \\
1.53 \pm 0.75\end{array}$ & $\begin{array}{l}\text { TR: } \\
\text { NS }\end{array}$ \\
\hline $\mathrm{V}_{\text {area }} \mathrm{PL}$ & $1 / \mathrm{kg} \mathrm{BW}$ & $\begin{array}{c}2.28 \pm 0.62 \\
6.0 \pm 1.9\end{array}$ & $\begin{array}{c}3.55 \pm 0.59 \\
7.9 \pm 1.5\end{array}$ & $\begin{array}{l}0.005 \\
\text { NS }\end{array}$ \\
\hline $\begin{array}{l}\text { MRT T after } \mathrm{DPLP}_{\mathrm{P}} \\
\mathrm{MRT}_{\mathrm{PL} \text { after }}{ }^{\mathrm{PL}}\end{array}$ & $\begin{array}{l}\mathrm{n} \\
\mathrm{n}\end{array}$ & $\begin{array}{c}3.7^{2} \\
2.7 \pm 1.0\end{array}$ & $\begin{array}{l}5.1 \pm 1.3 \\
3.1 \pm 1.1\end{array}$ & $\begin{array}{l}\text { NS } \\
\text { NS }\end{array}$ \\
\hline$F_{P L P} \rightarrow P L$ & $\%$ & 1282 & $125 \pm 32$ & NS \\
\hline
\end{tabular}

NS, not significant; TR, trend, $P<0.1$.

2 Pooled samples. 
approximately the same dose was administered to rats significantly differing in weight. Basal PLP' concentration and $\lambda_{1}$ (curve PL after $\mathrm{DPL}_{\mathrm{PL}}$ ) were significantly lower in the older animals. $\mathrm{V}_{\mathrm{area}} \mathrm{PL}$ (in liters) was significantly larger in the older animals.

For the other biokinetic parameters no significant differences between age groups could be demonstrated. FPLPLP tended to be lower, $V_{1, P L}$ tended to be higher for the older animals, but differences did not reach statistical significance $(P<0.1)$.

\section{Discussion}

Basal plasma PLP concentration was found to be significantly lower in the older animals than in the younger age group (Table 1). Basal plasma PL concentration was not influenced by age (Table 2).

Several mechanisms have been proposed to explain the lower plasma PLP levels observed with increasing age in man and rat: (1) lower vitamin B-6 intake, (2) higher plasma PI.P elimination rate (higher alkaline phosphatase activity), (3) lower PLP synthesis rate (lower liver PLP release), and (4) changes in vitamin B-6 body stores. In our experimental animals, vitamin B-6 intake was not different between age groups. In the experiments described, the hypotheses tested were whether the observed age-associated decrease in basal plasma PLP level could be attributed to an increased PLP elimination rate, a decreased PLP synthesis rate, or both. To test these hypotheses, both PLP and PL were administered intravenously to the same animals. At physiological concentrations PLP in plasma is predominantly present in the form of an albumin complex $[22,23]$. PL is also bound to albumin in plasma, but to a lesser extent [22]. In order to administer the compounds of interest in a physiological form, both PLP and PL were incubated with plasma before dosing.

The biokinetic parameters reported here were calculated from observed plasma concentration-time curves by means of non-compartmental analysis only, which implies that the pools in the biokinetic model have no physiological identity. A different approach was chosen by Coburn and Townsend [24] who described a multicompartmental model ( 25 pools) of rat vitamin B-6 metabolism, starting from discrete body compartments with independently verifiable anatomical significance and using data gathered from several rat experiments, partly in vitro, performed by other research groups. However, Coburn and Townsend recognize that the 25-pool model is too complex for routine use.

For the hypotheses to be tested to be true, one of the following situations should be applicable:

1. If the observed decrease in plasma PLP concentration is caused by an agerelated increase in PLP elimination rate, $\mathrm{Cl}_{\mathrm{PLP}}$ is expected to increase and $F_{P L \rightarrow P L P}$ is expected to be constant; 
2. If, on the other hand, PLP synthesis rate (phosphorylation of PL) decreases with age, ClPLP should be constant and FPL $\rightarrow$ PLP should decrease;

3. If both $P L P$ elimination rate increases and $P L P$ synthesis rate decreases with age, ClPLP will increase and $F_{\text {PL } \rightarrow P L P}$ will decrease concomitantly. However, both Cl PLP and FPL $\rightarrow$ PLP could be influenced by age-associated changes occurring in PL disposition.

Before drawing conclusions from PLP biokinetic parameters, PL biokinetic parameters should be considered as well. If, for example, $\mathrm{Cl}_{\mathrm{PL}}$ increases with age, F PL $\rightarrow$ PLP is expected to decrease because PLP synthesis from PL and PL clearance are competitive processes. On the other hand, the metabolic pathway for the degradation of PLP in mammalian tissue involves dephosphorylation to PL [25]. Hydrolysis of PLP is considered to be an important metabolic route in plasma as well [26]. If PL clearance is limiting for PLP elimination, $\mathrm{Cl}_{\mathrm{PLP}}$ will increase if $\mathrm{Cl}_{\mathrm{PL}}$ increases with age. Finally, changes in clearance can be attributed in general to changes in volumes of distribution or to changes in rate constants. Therefore, $V_{1}, V_{\text {area }}, \lambda_{1}$ and $\lambda_{2}$ for both PL and PLP are also important biokinetic parameters to be considered.

In our experimental animals neither $\mathrm{Cl}_{\mathrm{PLP}}$ nor $\mathrm{Cl}_{\mathrm{PL}}$ was significantly influenced by age, either expressed in $1 / \mathrm{h}$ or in $1 / \mathrm{h}$ per $\mathrm{kg} \mathrm{BW}$ (Tables 1 and 2). $\mathrm{Cl}_{\mathrm{PL}}$ was found to be approximately five times larger than $\mathrm{Cl}_{\mathrm{PLP}}$. Significant differences between age groups were found for $\lambda_{1}$ of the PL curve after PL dosing, with old animals showing smaller $\lambda_{1}$, but not for $\lambda_{1}$ of the PLP curve

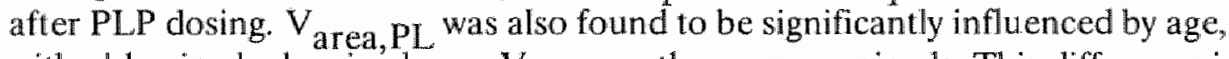
with old animals showing larger $V_{\text {area, }} P L_{\text {than young animals. This difference in }}$ $\mathrm{V}_{\text {area }} \mathrm{PL}$ might be related to the difference in body weight between young and old animals as $V_{\text {area, }} P L^{i n} 1 / \mathrm{kg} \mathrm{BW}$ was not significantly different between age groups. Both $V_{\text {area,PLP }}$ and $V_{\text {area,PLP }} / B W$ were comparable in young and old rats. No significant differences between age groups were found for $V_{1}$ and $\lambda_{2}$ for either PLP or PL. Average FPL $\rightarrow$ PLP was considerably smaller for the older than for the younger age group. However, due to large variation in the values calculated the difference did not reach statistical significance $(P=0.063)$. From these observations it was concluded that no indications were present for an agerelated increase of PLP elimination rate nor for an age-related decrease of PLP synthesis rate to explain the observed age-related decrease of (basal) plasma PLP' level.

In several experiments on guinea pigs [27], rats [28-30] and humans $[27,31-33]$, with radiolabeled vitamin B-6, evidence was found for a large vitamin B-6 compartment with slow turnover. In an elegant experiment on germfree rats, uniform labeling of the total body vitamin B-6 pool was demonstrated for the first time and was calculated to amount to $16.2 \pm 0.8 \mu \mathrm{mol}$ B-6 compound per $\mathrm{kg} \mathrm{BW}$ [30]. Approximately 75 to $80 \%$ of total isotope in the body was found in the carcass, i. e. striated muscle tissue. In striated muscle tissue vitamin B-6 is predominantly present as PLP bound to glycogen phosphorylase [34, 35]. In experiments on striated muscle tissue of mice labeled 
PLP was used to measure glycogen phosphorylase turnover [ 36 -38]. Depending on the muscle tissue examined, a half-life of 6 to 11 days was found. The authors suggested that muscle glycogen phosphorylase turnover in rats could very well be much slower than in mice because of the likely correlation with body size. In our model a terminal half-life comparable to the half-life of glycogen phosphorylase could have been overlooked due to the fact that plasma PLP and PL returned to baseline levels within two days.

Evidence for the presence of an additional vitamin B-6 compartment not included in our model was gained from estimation of the total vitamin B-6 body pool in our experimental animals from the calculated biokinetic parameters and from biochemical data on comparable animals. Using the values found for basal concentration and $V_{\text {area }}$ for both PL and PLP to calculate total body pool of vitamin B-6 a value of approximately $2 \mu \mathrm{mol} / \mathrm{kg} \mathrm{BW}$ was found for both age groups, which is very low. Vitamin B-6 levels found (PLP + pyridoxamine-5'phosphate) in gastrocnemius muscle tissue from male Wistar rats, 7 and 25 months of age, were approximately 30 and $25 \mu \mathrm{mol} / \mathrm{kg}$, respectively [16]. Assuming that the gastrocnemius muscle is representative of total rat muscle tissue, that muscle tissue accounts for approximately $40 \%$ of rat body weight and that muscle contains approximately $80 \%$ of total vitamin B-6 in the rat's body, total body pool of vitamin B-6 can be calculated to be approximately

$15 \mu \mathrm{mol} / \mathrm{kg} \mathrm{BW}$ and $12.5 \mu \mathrm{mol} / \mathrm{kg}$ BW for the 7 -month-old and the 25 -monthold animals, respectively. These values compare better with the $16.2 \pm 0.8 \mu \mathrm{mol} / \mathrm{kg} \mathrm{BW}$ found using tracer techniques in 6-month-olld germfree rats [30].

Knowing the values of total body vitamin B-6 content calculated from biochemical data, the fraction of the total body vitamin B-6 pool covered in our biokinetic experiment with unlabeled PLP and PL was approximated to be $15 \%$. Possibly the observed decrease of (basal) plasma PLP concentration with age is related to biokinetic changes in the aforementioned large vitamin B-6 compartment with slow turnover, comprising approximately $85 \%$ of total body pool. In the experiments reported here, relatively fast processes, plasma PLP synthesis and elimination, were studied. To investigate PLP (B-6) turnover of 'slow' compartments, rat studies with carbon-14-labeled $\mathrm{PN} \cdot \mathrm{HCl}$ have been performed. Results indicate lower long-term (halflife in days instead of hours) body retention of ${ }^{14} \mathrm{C}$ label dosed (to be published).

From our data several conclusions can be drawn regarding the (metabolic) fate of both plasma PLP and plasma PL. Although plasma PLP level is considered a reliable indicator of vitamin B-6 nutritional status the factors regulating its synthesis and clearance are as yet undefined.

PLP present in plasma is tightly bound to albumin. Albumin-bound PLP can not cross cellular membranes directly. Although albumin binding protects PLP against rapid hydrolysis to PL mediated by alkaline phosphatase, even albuminbound PLP is still prone to hydrolysis [23]. Although no direct evidence from in vivo studies has been reported so far it is generally accepted that plasma PLP is 
not absorbed directly by cellular tissue but that PL is the ultimate transport form $[25,39,40]$. Almost all mammalian tissues seem to possess PL-kinase activity, enabling trapping of absorbed PL through intracellular phosphorylation to PLP [41]. If plasma PLP is transported directly into tissues, $V_{1, P L P}$ is expected to be much larger than the extracellular fluid volume in our expermental animals. For man, the extracellular fluid volume is estimated at $0.18-0.22 \mathrm{~J} / \mathrm{kg} \mathrm{BW}[42]$. Assuming a similar value for rats, $V_{1}$, PLP was found to be considerably smaller than extracellular fluid volume (Table 1). $\mathrm{V}_{1, \mathrm{PL}}$, on the other hand, largely exceeded extracellular fluid volume (Table 2 ). On the basis of the present in vivo biokinetic study, and in agreement with earlier experiments in vitro, it is concluded that plasma PL is taken up into (tissue) cells directly, whereas the phosphorylated vitamin B-6 vitamer PLP is not. $V_{\text {area, }}$ PL is very large (much larger than $1 \mathrm{l} / \mathrm{kg}$ BW; Table 2), indicating extensive tissue binding, most likely through intracellular phosphorylation of PL to PLP.

If hydrolysis of plasma PLP to (plasma) PL is an important process in plasma PLP elimination, F PLP $\rightarrow$ PL should be large. In our experimental animals $F_{P L P} \rightarrow P L$ was found not to be significantly different from unity (Table 2). From these data it is concluded that plasma PLP is completely eliminated by metabolism, i. e. hydrolysis to PL. Phosphorylation of plasma PL to (plasma) PLP was demonstrated in our animals. On average, $16.7 \%$ and $6.7 \%$, in young and old

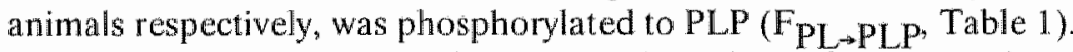

$M_{\text {MRT }}$ PLP after PLP was short, approximately one hour, meaning that PLP was cleared rapidly from plasma (Table 1). After PL dosing only a minor fraction was phosphorylated to PLP (F PL $\rightarrow$ PLP $_{2}<20 \%$ ). However, PLP formed after dosing of PL showed a prolonged residence time. MRT $P L P$ after $P L$ was significantly larger than one hour in both age groups, but a large variation in values was noted. MRT of PL, both after PL dosing and after PLP dosing, was also significantly longer than one hour (Table 2). MRT PL after PLP showed a significant tendency towards higher values than MRT $P L$ after $P L$ in old animals only $(P<0.05$, unpaired $t$-test). These MRT values for PL seem to be comparable to MRT of PLP after a PL dose. Explanation of the observed differences in MRT is difficult. One possibility is the occurrence of nonlinear kinetics of PLP. In a short feeding experiment with female rats, in which the animals were fed graded levels of dietary $\mathrm{PN}$ for 3 weeks, $\mathrm{Cl}_{\mathrm{PLP}}$ significantly varied between dose levels, with higher $\mathrm{Cl}_{\text {PLP }}$ at higher DPLP [43]. This is in line with the finding that after PLP dosing in the present experiment MRT PLP is shorter than after PL dosing. On the other hand, after PLP dosing MRT $\mathrm{PL}$ is longer than after PL dosing, which is contrary to our expectations.

The in vivo experiments reported here confirm results from studies of vitamin B-6 disposition in vitro: our data suggest that PL, not PL.P, is the ultimate transport form of vitamin B-6 from plasma into tissue cells, and that after tissue uptake of PL extensive tissue binding takes place. Furthermore, our data suggest that plasma PLP is not taken up into tissue cells; its metabolic fate is hydrolysis to PL. 
In conclusion, from our short-term biokinetic experiments in young and old rats no age-rellated difference in plasma PLP elimination rate nor in plasma PLP synthesis rate was observed to explain the observed decrease in plasma PLP concentration with age. This excludes explanation of lower plasma. PLP level with increasing age by an increase in (plasma) alkaline phosphatase activity or by a decrease of (liver) PLP releasing capacity. We hypothesize that instead of changes in these rellatively fast processes, changes in slowly exchanging vitamin B-6 body pools, i.e. muscle PLP disposition, result in a lower plasma PLP level at higher age.

\section{References}

1. Rose CS, György P, Butler M, Andres R, Norris AH, Shock NW, Tobin J, Brin M, Spiegel H. Age differences in vitamin B-6 status of 617 men. Am J Clin Nutr 1979:29:847-53.

2. Hamfelt A, Söderhjelm L. Vitamin B-6 and aging. In: Leklem JE, Reynolds RD, eds. Clinical and physiological applications of vitarmin B-6. New York: Alan R. Liss. 1988: 95-107.

3. Löwik MRH, van den Berg H, Westenbrink S, Wedel M, Schrijver J, Ockhuizen Th. Doseresponse relationships regarding vitamin B-6 in elderly people: a nationwide nutritional survey (Dutch Nutritional Surveillance System). Am J Clin Nutr 1089:50: 391-9.

4. Vir SC, Love AHG Vitamin B-6 status of the hospitalized aged. Am J Clin Nutr 1978:31: $1383-91$.

5. Garry PJ, Goodwin JS, Hunt WC, Hooper EM, Leonard AG. Nutritional status in a healthy elderly population: dietary and supplemental intakes. Am J Clin Nutr1982;36:319-31.

6. Guilland JC, Bereksi-Reguig B, Lequeu B, Moreau D, Klepping J, Richard D. Evaluation of pyridoxine intake and pyridoxine status among aged institutionalised people. Int J Vit Nutr Res 1984:54:185-93.

7. Löwik MRH, Westenbrink S, Hulshof KFAM, Kistemaker C, Hermus RJJ. Nutrition and aging: dietary intake of 'apparently healthy' elderly (Dutch Nutrition Surveillance System). J Am Coll Nutr 1989:8: 347-56.

8. Hoorn RKJ, Flikweert JP, Westerink D. Vitamin B-1, B-2 and B-6 deficiencies in geriatric patients, measured by coenzyme stimulation of enzyme activities. Clin Chim Acta 1975;61: $1.51-62$.

9. Lee CM, Leklem JE. Differences in vitamin B-6 status indicator responses between young and middle-aged women fed constant diets with two levels of vitamin B-6. Am J Clin Nulr 1985:42: 226-34.

10. Kant AK, Moser-Veillon PB, Reynolds RD. Efrect of age on changes in plasmat, erythrocyle, and urinary B-6 vitamers after an oral vitamin B-6 load. Am J Clin Nut 1988:48: 1284-90.

11. Lecle re J. Thiamine, riboflavine et vitamine Bw6 tissulaires chez le rat agế. II. Influence d'une surcharge vitaminique administrée dans le régime sur l"excrétion des vilamines et sur leurs taux tissulaires. Ann Nutr Alim 1.978; 32: 753-63.

12. Fonda ML, Eggers DK, Mehta R. Vitamin B-6 metabolism in the livers of young adult and senescent mice. Exp Gerontol 1980;15: 457-63.

13. Fonda ML, Eggers DK. Vitamin B-6 metabolism in the blood of young adult and senescent mice. Exp Gieroniol 1980; 15:465-72.

14. Fonda ML, Eggers DK, Auerbach S, Fritsch L. Vitamin B-6 metabolism in the brains of young adilt and senescent mice. Exp Gerontol 1980;15:473-9.

15. wan den Berg $H_{4}$ Bode W, Macking JAJ, Löwik MRH. Effect of aging on vitamin B-6 metabolism. Ann NY Acad Sci 1990:585: 96-105.

16. Bode W, Mocking JAJ, van den Berg $H$. Influence of age and sex on vittamin B-6 vitamer

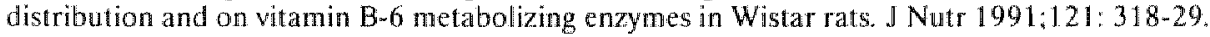


17. Cochary EF, Gershof SW, Sadowski JA. Aging and witamin Buf depletion: effects on plasma pyridoxel-5 -phosphate and erythrocyte aspartate aminotransferase actiwity coefficients in rats. Am J Clin Nutr 1990;51: 446-52.

18. Chabruer B, Livingstone D. A simple enzymatic assay for pyridoxal phosphate. Anal Biochem $1970: 34: 413-23$.

19. Schrijuer I, Spetk AJ, Schreurs WHP. Semi-automated fluorometric determination of pyridoxal5'-phosphate (vitamin B-6) in whole blood by high-performance liquid chromatography. Int J Vit Nurr Res 198:51:216-22.

20. Gibaldi M, Perrier D. Pharmacokinetics, 2nd Ed. New York: Marcel Dekker, 1982:45-111. 409-24.

21. Bieri JG, Stoewsand GS, Briggs GM. Phillips RW, Woodard JC, Knapka JJ. Report of the American Institute of Nutrition. Ad hoc comminte on standards for nutritional studies. I Nutr $1977: 107: 1340-8$

22. Anderson BB, Newmark PA, Rawling M, Green R. Plasma binding of vitamin B-6 compounds. Nature $1974 ; 250: 502-4$.

23. Lumeng L, Brashear RE, Li T-K. Pyridoxal-5'-phosphate in plasma: source, protein-binding and cellular transport. J Lab Clin Med 1974;84:334-43.

24. Coburn SP. Townsend DW. A multicompanment model of vitamin B-6 metabolism. Progr Food Nutr Sci $1988 ; 12: 227-42$.

25. Lumeng L, Li T.K. Mammalian vitamin B-6 metabolism: regulatory role of protein-binding and the hydrolysis of pyridokal- $5^{\circ}$-phosphate in storage and transport. In: Tryfiates GP, ed. Vitamin B-6 metabolism and rolle in growh. Westport, CT: Food, Nutrition Press, 1980: 27-52.

26. Lumeng $L_{\text {. }}$ Schenker $S$, Li T-K. Brashear RE, Compton MC. Clearance and metabolism of plasma pyridoxal .5' - phosplate in the dog. J Lab Clin Med 1984;103: 59-69.

27. Coburn SP, Mahuren JD, Erbelding WF, Townsend DW, Hachey DL, Klein PD. Measurement of vitamin $B-6$ kinetics in vivo using chronic administration of labelled pyridoxine. In: Che mical and biological aspects of vitamin B-6 catalysis, Part A. New York: Alan R. Liss, 1984: 43-54.

28. Cox SH, Murray A, Boone IU. Metabolism of tritium-labeled pyridoxine in rats. Proc Soc Exp Biol Med 1962:109:242-4.

29. Shane B. Vitamin B-6 metabolism and turnover in the ethanol-fed rat. J Nutr 1982:112:610-8.

30. Coburn SP, Maliuren JD, Wostmann BS, Snyder DL, Townsend DW. Role of intestinal microflora in the metabolism of vitamin B-6 and 4'-deoxypyridoxine examined using germfree guinea pigs and rats. J Nutr 1 989:119: 181-8.

31. Tillotson JA, Sauberlich HE, Baker EM, Canham JE. Use of carbon-1 4 labeled vitamins in human nutrition studies: pyridoxine. In: Proceedings of the Seventh International Congress on Nutrition, Vol. 5. Oxford: Pergamon Press 1966: 554-7.

32. Johansson S, Lindstedt S, Register U, Wadström L. Studies on the metabolism of labeled pyridoxine in man. Am I Clin Nurr 1966;18; 185-96.

33. Shane B. Vitamin B-6 and blood. In: Human vitamin B-6 requirements. Washington DC: National Academy of Scitnces 1978:111-28.

34. Black AL, Guirard BM, Snell EE. Increased muscle phosphorylase in rats fed high level of vitamin B-6. J Nutr $1977 ; 107: 1962-8$.

35. Russell LE, Bechtel PJ, Easter RA. Effect of deficient and excess dietary vitamin B-6 on amino transaminase and glycogen phosphorylase activity and pyridowal phosphate content in two muscles from postpubertal gilts. J Nutr 1985;115: 1 124-35.

36. Butler PE Cookson EJ, Beynon R.J. The turnover of skeletal muscle glycogen phosphorylase studied using the cofactor, pyridoxal phosphate, as a specific label. Biochim Biophys Acta 1985;8,47:316-23.

37. Beynon RJ, Fairhurst D, Cookson EJ. Turnover of skeletal muscle glycogen phosphorylase. Biomed Biochim Acta 1986;45: 1619-25.

38. Cookson EJ, Beynon RJ. Further ewaluation of cofactor as a turnover label for glycogen phosphorylase. Int J Biochem 1989:21: 975-82.

39. Anderson BB, Fulford-Jones CE, Child JA. Beard MEJ, Bateman CJT. Conversion of vitamin B-6 compounds to active forms in the red blood cell. J Clin Invest 1971;50: 1901-9.

40. Suzue R. Tachibana M. The uptake of pyridoxal phosphate by human red blood cells. J Vitaminol 1979:16:164-7\%. 
41. McCormick DB, Gregory ME, Snell EE Pyridoxal phosphokinases. I. Assay, distribution. purification and properties. J Biol Chem 1961:236:2076-84.

42. Rowland M, Tozer TN. Clinical Pharmacokinetics. Concepts and Applications. Philadelphia: Lea \& Febiger, 1980: 41.

43. Bode W, Hekman P, wan den Berg H. Influence of vitamin B-6 mutritional status upon plasma kinetics of PLP after I. V. dosing to rats. In: Korpela T, Christen P, eds. Biochemistry of vitamin B-6. Proceedings of the 7 th international congress on chemical and biological aspects of vitamin B-6 catalysis. Basel: Birkhäuser Verlag 1987: 407-10. 



\section{Pyridoxal-5'-phosphate release from the isolated perfused rat liver after pyridoxal dosing: influence of age}

Wilhelmina Bode and Henk wan den Berg

\section{Abstract}

Pyridoxal (PL) disappearance on the one hand and pyridoxal-5'-phosphate (PLP) and 4-pyridoxic acid (4-PA) release on the other were studied in the isolated, perfused rat liver. Livers were obtained from young ( 6 months of age) and old (31 months of age) male Wistar rats fed from weaning a semipurified diet contaning $250 \mathrm{~g}$ casein and $3 \mathrm{mg}$ pyridoxine $\cdot \mathrm{HCl}$ per $\mathrm{kg}$. During control perfusion (no $\mathrm{PL}$ administered) no difference in PL nor in PLP release from the liver into perfusate was observed between young and old rats, but 4-PA release was lower in old than in young rats. After dosing of PL into the perfusate PL clearance was not dosedependent and equalled perfusate flow rate in both age groups. PLP release into perfusate due to $\mathrm{PL}$ dosing was dose-dependent with a lower relative PLP release after a higher PL dose. 4-PA release into perfusate increased more than proportionally after a higher PL dose. Rate of PLP release into perfusate due to PL dosing was larger for the old rats than for the young ones, but amoumts released were comparable for both age groups. Recovery in perfusate of PL dosed was lower for old than for young rat livers, but liver uptake corrected for liver weight was similar. 11 is concluded that in vitro PLP release from the perfused rat liver after PL dosing does not differ between young and old rats.

\section{Introduction}

Plasma pyridoxal-5'-phosphate (PLP) concentration is a widely used vitamin B-6 status indicator. Elderly people generally show a higher incidence of PLP levels suggestive of marginal or deficient vitamin B-6 status [1-3]. The higher prevalence of biochemical vitamin B-6 deficiency in the aged could be related to low dietary vitamin B-6 intake [4-7]. However, evidence of age-related changes in vitamin B-6 metabolism has been reported gathered from experimental studies in man $[8,9]$ and in animals [10-14]. 
In order to gain more insight into the relation between vitamin B-6 (metabolism) and aging an extensive rat study was started in our Institute. In a biochemical experiment data suggestive of an age-related change in vitamin B-6 distribution among rat body compartments were found: rat heart and brain vitamin B- 6 content increased with age while plasma, liver, kidney and gastrocnemius muscle vitamin B-6 level decreased [15]. Concomitantly observed changes in organ tissue activities of vitamin B-6 metabolizing enzymes were not explanatory. Total body PLP elimination rate and total body PLP synthesis rate (from pyridoxal, PL) were studied in biokinetic experiments with cannulated rats and were not found to differ between young and old animals [16].

In organ ablation studies on dogs the liver was demonstrated to be the principal organ responsible for the formation of plasma PLP [17]. Therefore, plasma PLP concentration differences between age groups could be related to differences in liver PLP release after (liver) PL uptake. In this report experiments are described on PL disposition, including PL_P release, in the isolated, perfused rat liver from young and old male Wistar rats.

\section{Materials and methods}

\section{Animal handling}

Newly weaned male Wistar rats, Bor:WISW (SPF Cpb), obtained from F. Winkelmann, Borche, FRG, were fed a purified diet ad libitum, starting at an age of four weeks, containing $250 \mathrm{~g}$ casein and $3.2 \pm 0.1 \mathrm{mg}$ pyridoxine $\mathrm{HCl}(\mathrm{PN})$ per $\mathrm{kg}$ of diet. (For a detailed description of the experimental diet, except for vitamin B-6 content, see reference [18].) The animals were housed in groups of five in stainless steel cages in a well ventilated room at $23 \pm 1{ }^{\circ} \mathrm{C}$, with a relative humidity of $50 \pm 10 \%$, and a light-dark cycle of $12 \mathrm{~h}$. All animals had free access to tap water. At the age of 6 months and at the age of 31 months 20 animals from different cages were used in the liver perfusion experiments. The experimental protocol was approved by the Instinute's Committee for Research on Experimental Animals.

\section{Liver perfusion}

Experiments were started at either $10.00-10.30$ or 14.00-14.30. After diethyl ether anesthesia the liver was surgically excised and perfused in a recirculating system. Perfusate (total volume $50 \mathrm{ml}$ of modified Krebs-Henseleit buffer at $37{ }^{\circ} \mathrm{C}, \mathrm{NaCl}$ $118 \mathrm{mmol} / \mathrm{l}, \mathrm{KCl} 4.7 \mathrm{mmol} / \mathrm{l}, \mathrm{CaCl}_{2} \cdot 2 \mathrm{H}_{2} \mathrm{O} 2.5 \mathrm{mmol} / 1, \mathrm{KH}_{2} \mathrm{PO}_{4} 1.2 \mathrm{mmol} / \mathrm{l}$, $\mathrm{MgSO}_{4} \cdot 7 \mathrm{H}_{2} \mathrm{O} 1.2 \mathrm{mmol} / \mathrm{l}, \mathrm{NaHCO}_{3} 25 \mathrm{mmol} / \mathrm{l}$, glucose $0.15 \%$ in bidistilled water, equilibrated with $95 \% \mathrm{O}_{2}+5 \% \mathrm{CO}_{2}$ ) was circulated from the mixing reservoir by a peristaltic pump (LKB 2115) set at $10.0 \mathrm{ml} / \mathrm{min}$ via a membrane lung $\left(95 \% \mathrm{O}_{2}+5 \% \mathrm{CO}_{2}\right)$ and via a water-bath set at $37{ }^{\circ} \mathrm{C}$ into the liver through the portal vein. Effluent from the inferior vena cava was returned to the reservoir. 
Temperature was measured between liver lobes and regulated to $37 \pm 1^{\circ} \mathrm{C}$ with an infrared lamp. Perfusate $\mathrm{pH}$ was measured continuously throughout the experiment in the perfusate mixing reservoir and adjusted to $7.35-7.45$ with $1 \mathrm{~mol} / \mathrm{l} \mathrm{NaHCO}_{3}$ solution as necessary. Solutions, tubing and liver were protected from light throughout the experiment.

\section{Experimental protocol}

After a 30-min equilibration period a bolus dose of either 0,25 or $75 \mathrm{nmol} \mathrm{PL} \cdot \mathrm{HCl}$ dissolved in $500 \mu \mathrm{l}$ of perfusate was added to the reservoir and perfusion was continued for another $40 \mathrm{~min}$. Perfusate samples (500 $\mu \mathrm{ll})$ were collected from the mixing reservoir every 5 min throughout the experiment except for the first 10 min after dosing, when 3 or 4 samples were collected. Perfusate collected was replaced with an equal amount of blank perfusate kept at $37^{\circ} \mathrm{C}$. Perfusate samples were immediately stored on ice for the time of the experiment. After finishing the perfusion experiment, livers were blotted dry and weighed. Perfusate samples were stored at $-20^{\circ} \mathrm{C}$ until analysis. Liver viability was judged on the basis of gross appearance and biochemical parameters (aspartate aminotransferase (ASAT), alanine aminotransferase (ALAT) and lactate dehydrogenase (LDH) activities) measured in the final perfusate.

Analysis of samples

Perfusate ASAT, ALAT and LDH were measured on a Cobas-Bio centrifugal analyzer by standard methods for plasma samples according to the manufacturers" instructions. Perfusate PL and PLP concentrations were measured by a modification of the HPLC method described by Schrijver et al. [19]. Final perfusate 4-pyridoxic acid (4-PA) concentration was assessed by a modification of the HPLC method described by Gregory \& Kirk [20].

\section{Biokinetic analysis}

The observed perfusate PL and PLP concentration-time curves during blank perfusion were fitted with a standard non-linear regression program BMDP3R (BMDP Statistical Software Inc., Los Angeles, CA) to a monoexponential function:

$$
C(t)=C_{\max }-C_{\max } \cdot \exp \left(-k_{\text {app }} \cdot t\right)
$$

with $\mathrm{C}_{\max }$ the final concentration reached and $\mathrm{k}_{\text {app }}$ the rate constant of appearance.

The perfusate PL and PLP concentrations found after PL dosing were corrected for corresponding blank perfusion concentrations. Corrected PLP concentrations after PL dosing were fitted to the same function. Corrected PL concentrations after PL dosing were fitted to another monoexponential function after adjusting for increased PL release: 


$$
\mathrm{C}(\mathrm{t})=\mathrm{C}_{0} \cdot \exp \left(-\mathrm{k}_{\mathrm{el}} \cdot \mathrm{t}\right)
$$

with $\mathrm{C}_{0}$ concentration extrapolated to the time of dosing and $\mathrm{k}_{\mathrm{el}}$ the rate constant of elimination. PL clearance $(\mathrm{Cl})$ was calculated as dose $\cdot \mathrm{k}_{\mathrm{el}} / \mathrm{C}_{0}$.

\section{Slatistical analysis}

Analysis of variance (ANOVA) was performed on the calculated biokinetic parameters with the GENSTAT statistical package using the factor age (young, old) or the factors age (young, old) and dose (low, high) whenever appropriate. A probability level $(P)<0.05$ was considered significant. Data were expressed as mean \pm standard deviation $(\mathrm{SD})$.

\section{Results}

Perfusate PLP and PL concentrations found during control perfusion are shown in Fig. 1, changes in perfusate PLP and PL concentrations observed after dosing PL are illustrated in Figs 2 and 3 (low and high PL dose, respectively). No obvious differences in curve shape were observed between young and old rats, although old rats showed a tendency towards lower control perfusion concentrations than young rats (Fig. 1).

Liver weights and biokinetic parameters calculated from control liver perfusions are summarized in Table 1. Liver weight was significantly larger in the old animals than in the young ones. Final perfusate 4-PA concentration was low in all control perfusions, but was significantly lower for old than for young rats.

Biokinetic parameters describing the observed changes in perfusate PL concentration due to PL dosing are given in Table 2. Apart from the expected doserelated differences in $C_{0}$, no significant age- or dose-related differences were
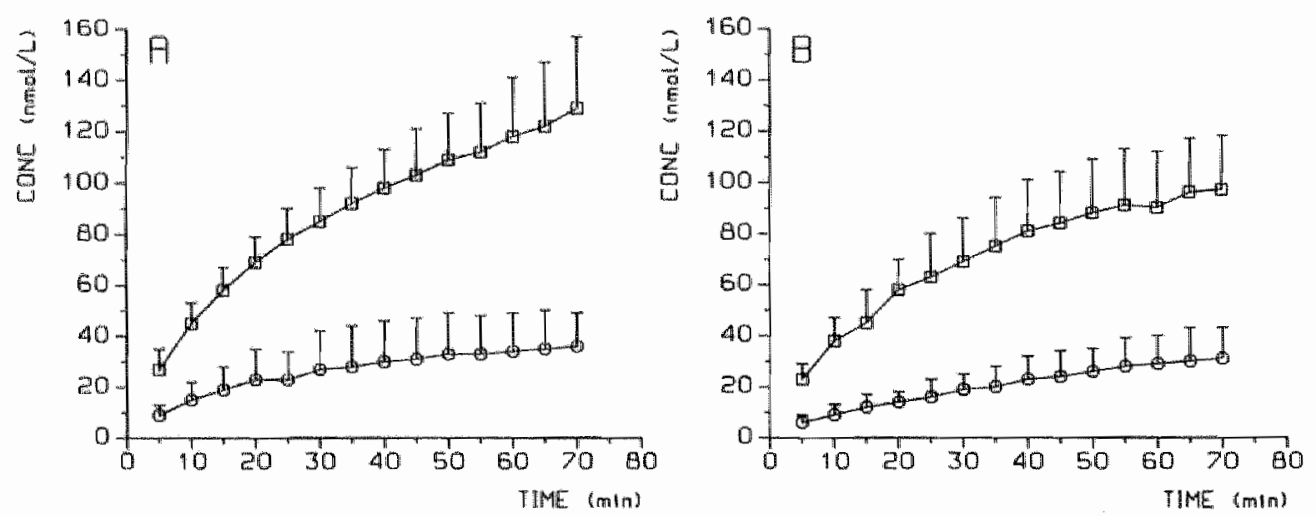

Fig. 1. Concentration (mean \pm SD) of PLP (squares) and PL (circles) in liver perfusate during control liver perfusion. A. age 6 months $(n=5)$ :

B. ange 31 months $(n=7)$. 

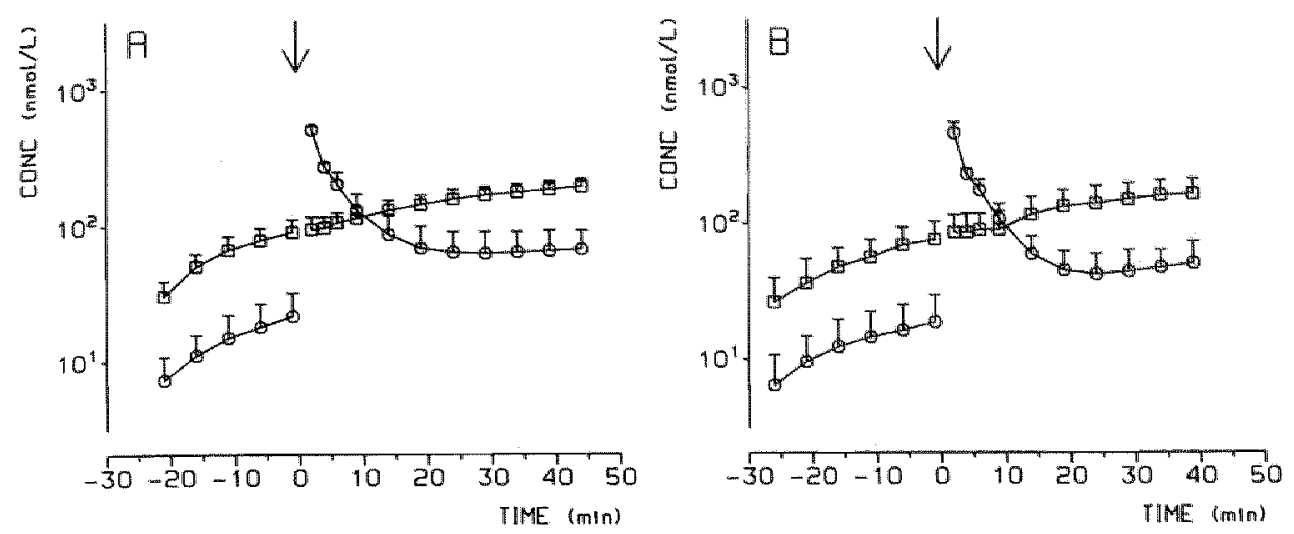

Fig. 2. Concentration (mean \pm SD) of PLP (squares) and PL (circles) in liver perfusate before and after a 25 nmol PL dose (arrow indicates time of dosing into perfusate). A, age 6 months $(n=7$ ); $B$, age 31 months $(n=6)$.
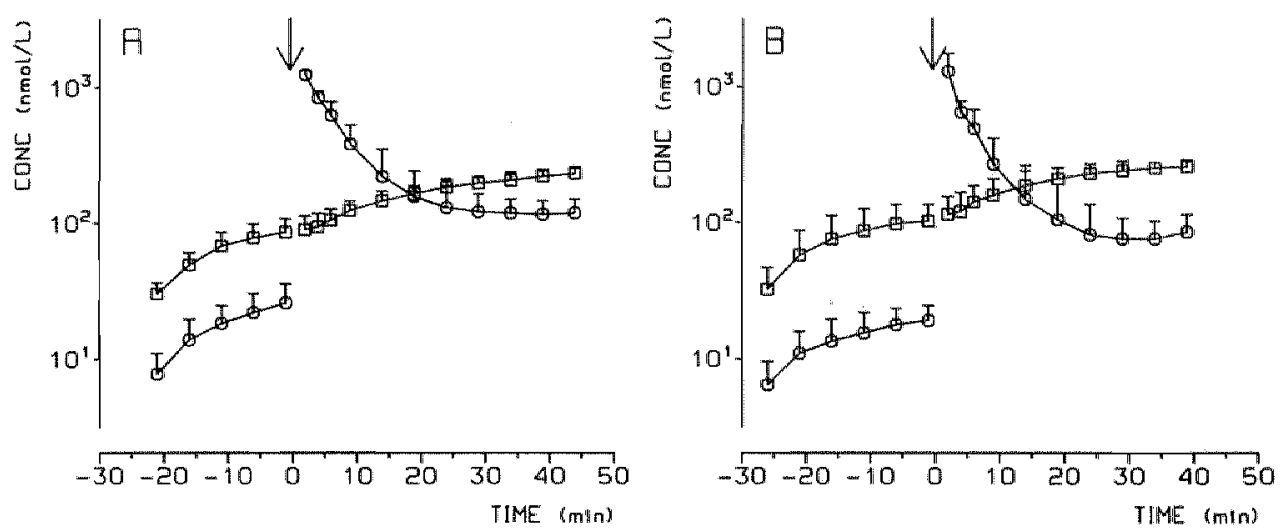

Fig. 3. Concentration (mean \pm SD) of PLP (squares) and PL (circles) in liver perfusate before and alter a 75 nmol PL dose (arrow indicates time of dosing into perfusate). A, age 6 months $(n=5$ ): $B$, age 31 months $(n=4)$.

Table 1. Liver PLP and PL release parameters (mean \pm SD) during control perfusion $(n=17)$.

\begin{tabular}{|c|c|c|c|c|}
\hline \multirow[t]{2}{*}{ Parameter } & \multirow[t]{2}{*}{ Unit } & \multicolumn{2}{|l|}{$\mathrm{Age}$} & \multirow[t]{2}{*}{ Significance } \\
\hline & & 6 months & 31 months & \\
\hline liver weight & (g) & $11.5 \pm 1.4$ & $13.1 \pm 2.1$ & $<0.05$ \\
\hline PLP C $\mathrm{C}_{\max }$ & $(\mathrm{mmol} 0)$ & $124 \pm 33$ & $111 \pm 34$ & $N S^{i}$ \\
\hline Pl.P k maxp & $\left(\min ^{-1}\right)$ & $0.052 \pm 0.020$ & $0.046 \pm 0.018$ & NS \\
\hline$P L C_{\max }^{\text {app }}$ & $(\mathrm{nmol} / \mathrm{l})$ & $38 \pm 19$ & $31 \pm 15$ & NS \\
\hline PL k & $\left(\min ^{-1}\right)$ & $0.046 \pm 0.022$ & $0.044 \pm 0.030$ & NS \\
\hline 4-PAC $\max$ & $($ m molld) & $22 \pm 7(n=5)$ & $13 \pm 4(n=7)$ & $<0.05$ \\
\hline
\end{tabular}

Not significant. 
Table 2. Liver PL disposition parameters (medn 2 SD corrected for control PL release) after PL dosing.

\begin{tabular}{|c|c|c|c|c|c|c|c|c|}
\hline \multirow[t]{2}{*}{ Parameter } & \multirow{2}{*}{$\begin{array}{l}\text { Dose } \\
\text { (nmol) }\end{array}$} & \multicolumn{4}{|l|}{$\mathrm{Age}$} & \multicolumn{3}{|c|}{ Significance } \\
\hline & & 6 months & $n$ & 31 months & $n$ & age & dose & age $\times$ dose \\
\hline \multirow{2}{*}{$\mathrm{C}_{0}(\mathrm{nmol} / \mathrm{l})$} & 2.5 & $517=116$ & 7 & $524 \pm 58$ & 6 & \multirow[t]{2}{*}{ NS } & \multirow[t]{2}{*}{$<0.001$} & \multirow[t]{2}{*}{ NS } \\
\hline & 75 & $1586 \pm 263$ & 5 & $1440 \pm 200$ & 4 & & & \\
\hline \multirow{2}{*}{$k_{e l}\left(\min ^{-1}\right)$} & 25 & $0.180 \pm 0.057$ & $?$ & $0.212 \pm 0.041$ & 6 & \multirow[t]{2}{*}{ NS } & \multirow[t]{2}{*}{ NS } & \multirow[t]{2}{*}{ NS } \\
\hline & 75 & $0.171 \pm 0.050$ & 5 & $0.207 \pm 0.084$ & 4 & & & \\
\hline \multirow[t]{2}{*}{$\mathrm{Cl}(\mathrm{ml} / \mathrm{min})$} & 25 & $9.1 \pm 1.6$ & 7 & $10.5 \pm 2.1$ & 6 & \multirow[t]{2}{*}{ NS } & \multirow[t]{2}{*}{$\mathrm{NS}$} & \multirow[t]{2}{*}{ NS } \\
\hline & 75 & $8.5 \pm 2.2$ & 5 & $10.9 \pm 3.8$ & 4 & & & \\
\hline \multirow{2}{*}{$\begin{array}{l}\text { PL release } \\
\text { (\% of dose) }\end{array}$} & 25 & $8.7 \pm 3.4$ & 7 & $7.2 \pm 3.1$ & 6 & \multirow[t]{2}{*}{ NS } & \multirow[t]{2}{*}{ NS } & \multirow[t]{2}{*}{ NS } \\
\hline & 75 & $7.3 \pm 2.7$ & 5 & $7.2 \pm 7.4$ & 4 & & & \\
\hline
\end{tabular}

Not signilicant.

Table 3. Liver PLP release parameters (mean \pm SD corrected for control PLP release) after PL dosing.

\begin{tabular}{|c|c|c|c|c|c|c|c|c|}
\hline \multirow[t]{2}{*}{ Parameter } & \multirow{2}{*}{$\begin{array}{l}\text { Dose } \\
\text { (nmol) }\end{array}$} & \multicolumn{4}{|l|}{ Age } & \multicolumn{3}{|c|}{ Significance } \\
\hline & & 6 months & $n$ & 31 months & $n$ & age & dose & age $\times$ dose \\
\hline \multirow{2}{*}{$\mathrm{C}_{\max }(\mathrm{nmol} / \mathrm{l})$} & 25 & $84 \pm 30$ & 7 & $77 \pm 34$ & 6 & \multirow[t]{2}{*}{$\mathrm{NS}^{1}$} & \multirow[t]{2}{*}{$<0.0011$} & \multirow[t]{2}{*}{ NS } \\
\hline & 75 & $1128 \pm 23$ & 5 & $138 \pm 116$ & 4 & & & \\
\hline \multirow{2}{*}{$k_{\text {app }}\left(\min ^{-1}\right)$} & 25 & $0.058 \pm 0.029$ & 7 & $0.111 \pm 0.075$ & 6 & \multirow[t]{2}{*}{$<0.05$} & \multirow[t]{2}{*}{ NS } & \multirow[t]{2}{*}{ NS } \\
\hline & 75 & $0.080 \pm 0.028$ & 5 & $0.176 \pm 0.114$ & 4 & & & \\
\hline \multirow{2}{*}{$\begin{array}{l}\text { PLP release } \\
\text { (\% of dose })\end{array}$} & 25 & $15.8 \pm 5.6$ & 7 & $14.9 \pm 6.7$ & 6 & \multirow[t]{2}{*}{ NS } & \multirow[t]{2}{*}{$<0.01$} & \multirow[t]{2}{*}{ NS } \\
\hline & 75 & $8.1 \pm 1.4$ & 5 & $9.0 \pm 1.0$ & 4 & & & \\
\hline
\end{tabular}

${ }^{1}$ Not significant.

Table 4. Liver 4.PA release and total release of PL, PLP and 4-PA combined (mean \pm SD) after PL dosing.

\begin{tabular}{|c|c|c|c|c|c|c|c|c|}
\hline \multirow[t]{2}{*}{ Parameter } & \multirow{2}{*}{$\begin{array}{l}\text { Dose } \\
\text { (nnol) }\end{array}$} & \multicolumn{4}{|l|}{ Age } & \multicolumn{3}{|c|}{ Significance } \\
\hline & & 6 months & $n$ & 31 months & $n$ & age & dose & age $\times$ dose \\
\hline 4-PA release & 25 & $27.4 \pm 7.1$ & 7 & $18.3 \pm 3.7$ & 6 & $<0.001$ & $<0.01$ & $\mathbb{N S}^{1}$ \\
\hline (\% of dose $)$ & 75 & $36.8 \pm 4.6$ & 5 & $25.3 \pm 4.8$ & 4 & & & \\
\hline total release & 25 & $52.2 \pm 3.2$ & 7 & $40.5 \pm 5.4$ & 6 & $<0.001$ & NS & NS \\
\hline$(\%$ of dose $)$ & 75 & $52.2 \pm 6.4$ & 5 & $41.4 \pm 11.8$ & 4 & & & \\
\hline
\end{tabular}

'Not significant. 
observed. Furthermore, mean perfusate PL clearance was not significantly different from perfusate flow rate in any experimental group.

Biokinetic parameters describing the observed changes in perfusate PLP concentration due to PL dosing are summarized in Table 3. As expected, $\mathrm{C}_{\max }$ corrected for control PLP release was observed to be dose-dependent. PLP release expressed as a percentage of PL dosed, however, was found to be dose-dependent, too. Relative PLP release was lower after the higher PL dose. Old rats showed significantly larger $k_{a p p}$ values than young rats at both dose levels.

Recoveries in perfusate of PL dosed, as 4-PA and as a grand total of PL, PLP and 4-PA combined, are presented in Table 4. 4-PA release as a percentage of PL dosed was significantly lower in the older animals than in the young ones. Furthermore, 4-PA release increased more than proportionally with the higher PL dose. Total release, as a percentage of PL dosed, was not dose-dependent. However, older rats showed a lower total release than young animals.

\section{Discussion}

The animals used in the liver perfusion experiment described were fed a purified diet containing approximately $50 \%$ of the recommended vitamin B-6 level from weaning [21]. In a parallel feeding experiment with rats fed diets containing graded levels of vitamin B-6 no significant differences in vitamin B-6 status parameters were observed between rats fed a diet containing the recommended level of vitamin B-6 and rats fed the same diet as the animals used in this experiment (unpublished results). This suggests that the vitamin B-6 requirement of the experimental animals was met when they were fed a diet containing $3 \mathrm{mg} \mathrm{PN}$. HCl per $\mathrm{kg}$ (or $12 \mu \mathrm{g} \mathrm{PN} . \mathrm{HCl}$ per $\mathrm{g}$ protein), which is in line with earlier observations [22-24]. If rats were fed a diet containing more vitamin B-6 (equal to or higher than the recommendation), vitamin B-6 intake probably would be far in excess of cellular demand and subtle age-related changes in liver vitamin B-6 metabolic capacity might be overlooked.

PLP and PL are the predominant B-6 vitamers present in rat plasma. Of the total amount of (active) vitamin B-6 present, $85-95 \%$ has been observed to be in the aldehyde forms PL and PLP [24 25]. In the experiments reported here no attempt was made to measure the minor amounts of other vitamers present.

During control perfusion total PL and PLP released added up to $8.1 \pm 2.6 \mathrm{nmol}$ and $7.2 \pm 2.5 \mathrm{nmol}$ for the young and old rats, respectively. Release observed here was somewhat higher than total vitamin B-6 content of perfusate observed after a three-hour control perfusion by Sorrell et al, viz. $5.8 \pm 1.0 \mathrm{nmol}$ PN equivalents [26]. However, in this earlier experiment younger rats with smaller livers than our experimental animals were used.

Total vitamin B-6 content of liver is large compared to the total amount of PLP, PL and 4-PA released into perfusate. In livers of male Wistar rats from the same cohort as the animals studied here PLP and pyridoxamine-5'-phosphate (PMP) concentrations added up to $44.7 \pm 3.9 \mathrm{nmol} / \mathrm{g}$ liver for 13 -month-old rats and 
$37.2 \pm 4.9 \mathrm{nmol} / \mathrm{g}$ liver for 31 -month-old rats (mean $\pm \mathrm{SD}$, unpublished results). The variation in PLP and PMP content of nonperfused liver is larger than the amount of PL dosed during liver perfusion. Therefore, no attempt was made to measure and compare vitamin B-6 content of livers after perfusion.

In rats fed purified diets containing (synthetic) $\mathrm{PN}$. $\mathrm{HCl}$, the vitamer released into the portal circulation most likely is PN [27]. Transport and metabolism of PN in perfused rat liver has been studied earlier [28]. After ${ }^{3} \mathrm{H}-\mathrm{PN}$ dosing a substantial amount of ${ }^{3} \mathrm{H}-\mathrm{PL}$ and some ${ }^{3} \mathrm{H}$-PLP was released into the perfusate. Liver PL and PLP release after PN dosing requires phosphorylation of PN to pyridoxine-5:phosphate (PNP) by the enzyme PL-kinase (ATP:pyridoxal-5' -phosphotransferase; EC 2.7.1.35), followed by oxidation of PNP to PLP by the enzyme PNP-oxidase (pyridoxamine-5'phosphate:oxido-reductase; EC 1.4.3.5). PLP formed could then be released into the perfusate directly or could be dephosphorylated to PL first. Rat liver PL-kinase and PNP-oxidase activities (measured in vitro) have been observed to increase with age [15]. As a result, the liver's capacity to convert dietary PN into PLP is not likely to be limited in older rats. In this study we therefore concentrated on disposition of PL.

After PL dosing PL disappeared rapidly from perfusate (Figures 2 and 3 ). Perfusate PL clearance was essentially equal to perfusate flow rate (Table 2), indicating a high liver extraction ratio. Results from in vitro studies on transport of vitamin B-6 compounds into erythrocytes suggest that PL crosses cellular membranes readily [29]. Perfusate PL clearance was linear in the PL concentration range used.

PLP release in excess of control PLP release was observed after PL dosing (Figs 2 and 3, Table 3), suggesting PL absorbed is phosphorylated intracellularly to PLP and then released into the perfusate. PLP release was not linear with respect to the amount of PL dosed. Lower (relative) PLP release at the higher dose level could be explained by two mechanisms: limited enzyme capacity or limited transport capacity. Limited capacity of PL-kinase, the enzyme involved in phosphorylation of PL to PLP, is not likely to be the causal factor: PL-kinase activity in liver tissue of rats is high [15]. However, another enzyme, PL-oxidase (aldehyde:oxygen oxidoreductase; EC 1.2.3.1) is present in liver to compete for substrate PL. With PL-oxidase activity present PL is oxidized to 4-PA. Both PL-kinase and PL-oxidase are cytosolic enzymes and have comparable $\mathrm{K}_{\mathrm{m}}$ values for PL under physiological conditions [30]. Activity of PL-oxidase is higher than activity of PL-kinase [15 30], thus favoring PL oxidation over PL phosphorylation. Relative 4-PA release was observed to be higher after the higher PL dose (Table 4). Competition of PL-kinase and PL-oxidase for PL seems a likely explanation for the lower PLP release after the higher PL dose.

The amount of PLP released due to PL dosing was not observed to differ between age groups (Table 3). The old rats showed a significantly larger rate of PLP excretion $\left(k_{\text {app }}\right)$ than the younger ones. Variation in $k_{\text {app }}$ values, especially in the old animals, was large, so the relevance of this age-related difference might be low. However, from the values observed for liver PLP released and rate of liver PLP release for old rats compared to young rats it is concluded that limited PLP release from the liver 
after PL dosing does not explain the lower plasma PLP concentrations found in old rats as compared to young ones.

Recovery of dose in the form of PLP, PL or 4-PA released into perfusate was not dose-dependent but was lower in old than in young rats (Table 4). This might indicate that a larger percentage of the dose administered is accumulated in old livers than in young ones. However, with the old rats having larger livers than the young ones (Table 1 ), dose accumulated corrected for liver weight was not different.

In conclusion, the observations in our in vitro liver perfusion study are congruent with earlier observations made in an in vivo biokinetic study on intact rats [16]: liver PLP release into perfusate after PL dosing does not differ between livers from young and old rats. An age-rellated decrease in the liver's capacity to phosphorylate PI to PLP followed by PLP release does not explain the lower plasma PLP levels observed in old as compared to young rats. The processes studied in the liver perfusion experiment are fast, with rate constants corresponding to half-lives up to 1.5 minutes. Indications for a large vitamin B-6 body pool with slow turnover were reported in experiments with ${ }^{14} \mathrm{C}$-labelled vitamin B-6 [31-37]. Possibly age-related changes in this vitamin B-6 body compartment offer an explanation for the decrease in plasma PLP concentration with age.

\section{References}

1. Rose CS, György P, Butler M, Andres R, Norris AH, Shock NW, Tobin J, Brin M, Spiegel H. Age differences in vitamin B-6 status of 617 men. Am J Clin Nutr 1976;29:847-53.

2. Hamfelt A, Söderhjelm L. Vitamin B-6 and aging. In: Leklem JE, \& Reynolds RD, eds. Clinical and physiological applications of vitamin B-6. Current topics in nutrition and disease, Yol. 19. New York: Alan R. Liss, 1988: 95-107.

3. Löwik MRH, van den Berg H, Westenbrink S, Wedel M, Schrijwer J, Ockhuizen Th. Dose response relationships regarding vitamin B-6 in elderly people: a nationwide nutritional survey (Dutch Nutritional Surveillance System). Am J Clin Nutr 1989:50: 391-9.

4. Vir SC, Love AHG. Vitamin B-6 status of the hospitalized aged. Am J Clin Nutr 1978;31: $1383-91$.

5. Garry PJ, Goodwin JS, Hunt WC, Hooper EM, Leonard AG. Nutritional status in a heallhy elderly population: dietary and supplemental intakes. Am J Clin Nutr 1982;36: 319-31.

6. Guiltand JC, Bereksi-Reguig B, Lequeu B, Moreau D, KJepping J, Richard D. Evaluation of pyridoxine untake and pyridoxine status among aged institutionalised people. Int J Vit Nutr Res 1984;54: 185-93.

7. Löwik MRH, Westenbrink S, Hulshof KFAM, Kistemaker C, Hermus RJJ. Nutrition and aging: dietary intake of 'apparently healthy" elderly (Dutch Nutrition Surveillance System). I Am Coll Nutr 1 989:8: 347-56.

8. Lee CM, Leklem JE. Differences in vitamin B-6 status indicator responses between yourng and middle-aged women fed constant diets with two levels of vitamin B-6. Am J Clin Nutr 1985;42: 226-34.

9. Kant AK, Moser-Veillon PB, Reynolds RD. Effect of age on changes in plasma, erythrocyte, and urinary B-6 vitamers after an oral vitamin B-6 load. Am J Clim Nuir 1988;48: 1284-90.

10. Leclerc J. Thiamine, riboflawine et vitamine B-6 tissulatres chez le rat agé. II. Influence d"une surcharge witaminique administrěe dans le régime sur l'excrétion des vitamines et sur leurs taux tissulaires. Ann Nutr Alim 1978;32:753 63. 
11. Fonda $M L$, Eggers $D$ K, Mehta $R$. Vitamin B-6 metabolism in the livers of young adult and senescent mice. Exp Gerontol 1980;15: 457-63.

12. Fonda ML, Eggers DK. Vitamin B-6 metabolism in the blood of young adult and senescent mice. Exp Gerontol 1980;15:465-72.

13. Fonda $M L$. Eggers $D K$, Auerbach $S$, Fritsch $L$. Vitumin $B-6$ metabolism in the brains of young adult and senescent mice. Exp Gerontol 1980;15: 473-9.

14. Cochary EF, Gershof SN, Sadowski JA Aging and vitamin B-6 depletion: effects on plasma pyridoxal-5' -phosphate and erythrocyte aspartate aminotransferase activity coefficients in rats. Am J Clin Nutr 1990;51 446-52.

15. Bode W, Mocking JA, van den Berg $H$. Influence of age and sex on vitamin B-6 vitamer distribution and on vitamin B-6 metabolizing enzymes in Wistar rats. J Nutr 1991; 121: 318-29.

16. Bode W, van den Berg H. Pyridoxal-5"-phosphate and pyridoxal biokinetics in aging Wistar rats. Exp Gerontol 1991 (in press).

17. Lumeng L, Schenker S, Li T-K, Brashear RE, Compton MC. Clearance and metabolism of plasma pyridoxal-5"-phosphate in the dog. J Lab Clin Med 1984;103:59-69.

18. van den Berg $\mathrm{H}$, Bogaards JJP. Vitamin B-6 metabolism in the pregnant rat: effect of progesterone on the (re) distribution in maternal vitamin B 6 stores. J Nutr 1987:117:1866-74.

19. Schrijver J, Speek AJ, Schreurs WHP. Semi-automated fluorometric determination of pyridoxal5'-phosphate (vitamin B-6) in whole blood by high-performance liquid chromatography. Int I Vit Nutr Reg 1981;51:216-22.

20. Gregory III JF, Kirk JR. Determination of urinary 4-pyridoxic acid using high performance liquid chromatography. Am J Clin Nutr 1979;32: 879-83.

21. Bieri JG, Stoewsand GS, Briggs GM, Phillips RW, Woodard JC, Knapka JJ. Report of the American Institute of Nutrition. Ad hoc committee on standards for nutritional studies. $J$ Nutr $1977 ; 107: 1340-8$.

22. Driskell $J A$, Kirksey A. The cellular approach to the determination of pyridoxine requirements in pregnant and non-pregnant rats. J Nutr 1971; 101: 661-8.

23. Driskell JA, Strickland LA, Poon CH, Foshnee DP. The vitamin B-6 requirement of the male rat as determined by behavioral patterns, brain pyridoxal phosphate and nucleic acid composition and erythrocyte alanine aminotransferase activity. $J$ Nutr 1973;103:670-80.

24. Driskell JA, Chrislcy BM, Pierotti JA, Hefferan TE. High-performance liquid chromatographic analysis of vitamin B-6 components in tissues and status assessment. Nutr Rep Int 1987;35: $1247-59$.

25. Schaeffer MC, Sampson DA, Skala JH, Gietzen DW, Grier RE. Evaluation of vitarnin B-6 status and function of rats fed excess pyridoxine. J Nutr 1989;1 19:1392-8.

26. Sorretl MF, Baker H, Barak A., Frank O. Release by ethanol of vitamins into rat liver perfusates. Am J Clin Nutr 1974;27: 743-5.

27. Buss DD, Hamm MW, Mehanso H. Henderson LM. Transport and metabolism of pyridoxine in the perfused small intestine and the hind limb of the rat. J Nutr 1980;110:1655-63.

28. Mehanso $H$, Buss DD, Hamm MW, Henderson LM. Transport and metabolism of pyridoxine in rat liver. Biochim Biophys Acta 1980;631: 112-23.

29. Lumeng L, Li T-K. Mammalian vitamin B-6 metabolism: regulatory role of protein-binding and the hydrolysis of pyridoxal-5'-phosphate in storage and transport. In: Tryfiates GP, ed. Vitamin B-6 Metabol ism and Role in Growth. Westport, CT: Food and Nutrition Press, 1980: 27-52.

30. Merrill AH, Henderson JM, Wang E, McDonald BW, Millikan WJ. Metabolism of vitamin B-6 by human liver. J Nutr 1984;1 14: 1664-74.

31. Cox SH, Murray A. Boone IU. Metabolism of tritium-labelled pyridoxine in rats. Proc Soc Exp Biol Med 1962:109:242-4.

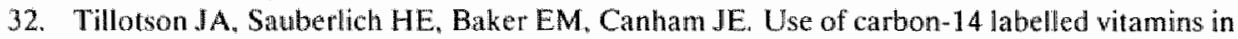
human nutrition studies: pyridoxine. In: Proceedings of the Seventh International Congress of Nutrition. Vol. 5, Physiology and Biochemistry of Food Components. Oxford: Pergamon Press. 1966: $554 \times 7$.

33. Johansson $S$, Lindstedt $S$, Register U, Wadström L. Studies on the metabolism of labelled pyridoxine in man. Am J Clin Nutr 1966;18: 185-96.

34. Shane B. Vitamin B-6 and blood. In: Human Vitamin B-6 Requirements. Washington DC: National Academy of Sciences, 1978:111-28. 
35. Shane B. Vitamin B-6 metabohism and turnover in the ethanol-fed rat. J Nutr 1982;112:610-8.

36. Coburn SP, Mahuren JD, Erbelding WF, Townsend DW, Hachey DL, Klen PD. Measurement of witamin $B-6$ kinetics in vivo using chronic administration of labelled pyridoxine. In: Chemical and Biological Aspects of Vitamin B-6 Catalysis, Part A. New York: Alan R. Liss, 1984: 43-54.

37. Coburn SP, Mahuren JD, Wostmann BS, Snyder DL. Townsend DW. Role of intestinal microflora in the metabolism of vitamin B-6 and 4'-deoxypyridoxine examined using germfree guinea pigs and rats. J Nutr 1989;119: 181-8. 



\title{
Lower retention of ${ }^{14} \mathrm{C}$ label in old Wistar rats than in young ones after oral dosing of $\left[{ }^{14}\right.$ C]pyridoxine
}

Wilhelmina Bode, Johannes A.J. Mocking and Henk van den Berg

\begin{abstract}
Ten young ( 6 months) and ten old ( 31 months) male Wistar rats fed a purified diet ( $250 \mathrm{~g}$ casein and $6 \mathrm{mg}$ pyridoxine $\cdot \mathrm{HCl}$ per $\mathrm{kg}$ ) from weaning were given either a single orall dose or five repeated oral doses of ${ }^{14} \mathrm{C}$-labeled pyridoxine (PN). At various times after dosing animals of each age group were killed. Absorption of orally dosed $\left[{ }^{14} \mathrm{C}\right] \mathrm{PN} \cdot \mathrm{HCl}$ was not found to differ between young and old rats. Total body retention of ${ }^{14} \mathrm{C}$ label administered was modestly but significantly lower in old than in young rats. However, distribution of ${ }^{14} \mathrm{C}$ label over various tissues, as well as among the various B-6 vitamers, were similar. No significant age-related differences were observed in the biokinetic parameters derived from urinary excretion data. Contrary to the findings for ${ }^{14} \mathrm{C}$ label distribution, age-related differences were observed for absolute level of tissue ${ }^{14} \mathrm{C}$-labeled vitamers. The lower ${ }^{14} \mathrm{C}$ |pyridoxal-5'-phosphate content in liver and muscle, and $\left[{ }^{14} \mathrm{C}\right]$ pyridoxamine- 5 -phosphate content in liver, of old animals indicate an age-related difference in liver and muscle vitamin B-6 disposition. In both young and old rats, and in both liver and muscle tissue, pyridoxamine-5"-phosphate was observed to be a faster-exchanging tissue vitamin B-6 pool than pyridoxal-5'-phosphate.
\end{abstract}

\section{Introduction}

Vitamin B-6 status is generally assessed by determining plasma pyridoxal5 -phosphate (PLP) concentration. Based on this measurement, a marginal or deficient vitamin B-6 status is highly prevalent among persons 65 and over [1-3]. This finding may be partly explained by the low dietary vitamin B-6 intake calculated for many elderly people [4-7]. However, in some studies $10-20 \%$ of the elderly did not show improved vitamin B-6 status after daily (oral) supplementation with 2-20 mg pyridoxine (PN) $[4,6,8]$. This observed lack of response to vitamin B-6 supplementation at a physiological dose may be indicative of a change in vitamin B-6 metabolism with age. Data from human studies are still scarce $[9,10]$, but many 
studies on rats and mice have suggested an age-related change in vitamin B-6 metabolism [1]-14].

Recently we reported data on the age- and gender-related effects on vitamin B-6 distribution and on vitamin B-6 metabolizing enzyme activities in Wistar rats [15]. Besides an age-related decrease in plasma PLP concentration, muscle PLP concentration was observed to be lower in the older animals, which is suggestive of an age-related decrease in vitamin B-6 body pool. In an attempt to explain the lower plasma PLP levels found in old rats biokinetic parameters for intravenously dosed PLP and pyridoxal (PL) were compared between 8-month-old and 27-month-old animals [16]. No difference in total body clearance of PLP or PL nor any difference in percentage of PL administered phosphorylated to PLP was found. However, in the experimental design of this relatively short-term study the "slow-turnover" vitamin B-6 compartment was not included [17-23].

The aim of the study reported here was to describe the age-related changes in vitamin B-6 biokinetics in the rat including any compartment with very slow turnover. In the first experiment, young and old male Wistar rats were given one oral dose of ${ }^{14} \mathrm{C}$ labeled PN. Distribution and excretion of label were measured and compared between age groups. In the second experiment, young and old Wistar rats were administered repeated oral doses of ${ }^{14} \mathrm{C}$ labeled $\mathrm{PN}$, in an attempt to increase specific activity of especially the vitamin B-6 body pool with slow turnover. The second experiment was included to support results obtained in the first experiment.

Materials and methods

\section{Materials}

$\mathrm{PN} \cdot \mathrm{HCl}, \mathrm{PL} \cdot \mathrm{HCl}$ and $\mathrm{PLP} \cdot \mathrm{H}_{2} \mathrm{O}$ were obtained from Merck (Darmstadt, Germany), 4-pyridoxic acid (4-PA), pyridoxamine $\cdot \mathrm{HCl}(\mathrm{PM})$ and pyridoxamine-5'-phosphate- $2 \mathrm{HCl}$ (PMP) from Sigma (St. Louis, MO). Alkaline phosphatase (AP, EC 3.1.3.1) was purchased from Boehringer (Mannheim, Germany). Nucleosil 5SA (10 $\mu \mathrm{m}$ ) was obtained from Machery-Nagel (Düren, Germany) and Hypersil ODS (3 $\mu \mathrm{m}$ ) from Shandon Southern Products (Runcort, Great Britain). Hionic Fluor and Soluene 350 were purchased from Canberra Packard Benelux (Tilburg, Netherlands). All other chemicals used were reagent grade.

$\left[4,5-{ }^{14} \mathrm{C}\right] \mathrm{PN} \cdot \mathrm{HCl}$, al a specific activity of $0.24 \mathrm{TBq} / \mathrm{mol}$, was generously provided by R.D. Reynolds, US Department of Agriculture, Beltsville, MD. The ${ }^{14}$ C-labeled $\mathrm{PN} \cdot \mathrm{HCl}$ was purified by column chromatography on cellulose phosphate (eluent $0.1 \mathrm{~mol} / \mathrm{l}$ sodium acetate buffer at $\mathrm{pH} 4.7$ ).

\section{Animals}

Newly weaned male Wistar rats, Bor:WISW (SPF CPb), were obtained from F. Winkelmann (Borche, Germany). All animals were fed a purified diet ad libitum, 
containing $250 \mathrm{~g}$ casein and $5.9 \pm 0.9 \mathrm{mg} \mathrm{PN} \cdot \mathrm{HCl}$ per $\mathrm{kg}$ The composition of the experimental diet, except for vitamin B-6, was as clescribed [24]. The animals were housed in groups of five each in stainless steel cages in a well-ventilated room at $23 \pm 1{ }^{\circ} \mathrm{C}$, with a relative humidity of $50 \pm 10 \%$, and a light-dark cycle of $12 / 12 \mathrm{~h}$. All animals had free access to tap water. Body weight and food intake were monitored longitudinally for all rats, at weekly intervals until 4 months of age and every 4 weeks thereafter.

\section{Experimental protocol}

The experimental protocol was approved by the Institute's Committee for Research on Experimental Animals. At an age of 6 months and at an age of 31 months (ca. $30 \%$ survivorship) ten rats were randomly selected from different cages and housed individually in stainless steel metabolism cages for the duration of the experiments. The animals were allowed two days to adjust to their new environment.

\section{Experiment 1}

Between 09.00 and 10.00 six animals of each age group were administered purified $\left.{ }^{14} \mathrm{C}\right] \mathrm{PN} \cdot \mathrm{HCl}$ (ca. $0.12 \mathrm{MBq}$ and $0.50 \mu \mathrm{mol} \mathrm{PN} \cdot \mathrm{HCl}$ in $0.7 \mathrm{ml}$ ) by stomach tube. During the following $24 \mathrm{~h}$ the animals were fed a purified diet without $\mathrm{PN} \cdot \mathrm{HCl}$ added (measured $\mathrm{PN} \cdot \mathrm{HCl}$ content $0.3 \pm 0.2 \mathrm{mg} / \mathrm{kg}$ ), after which they were again fed the original diet. Food intake was monitored daily and all urine and feces excreted were collected. One day after dosing 3 animals of each age group were killed by exsanguination. Blood was collected from the abdominal aorta under diethyl ether anesthesia. Liver, heart, kidneys, brain as well as both gastrocnemius muscles were collected and weighed. All samples were quickly frozen and stored at $-20^{\circ} \mathrm{C}$. The other three rats were killed 47 days after dosing, following the same procedure.

\section{Experiment 2}

The procedure was identical to that in experiment 1, but now the animals (four of each age group) were administered the described oral | $\left.{ }^{14} \mathrm{C}\right] \mathrm{PN} \mathrm{HCl}$ dose on five consecutive days. One animal of each age group was killed $1,4,8$ or 12 days after the last oral dose.

\section{Sample preparation and measurement of radioactivity}

Total radioactivity in liver, kidney, brain, heart, gastrocnemius muscle and whole blood was measured in triplicate. Samples $(100 \mathrm{mg})$ were solubilized overnight with $1.50 \mathrm{ml}$ Soluene 350 , followed by decolorization with concentrated hydrogen peroxide $(300 \mathrm{~g} / \mathrm{l}, 0.75-1.50 \mathrm{ml}$ ). Triplicate 100 to $500 \mathrm{mg}$ urine samples (size depending on expected radioactivity present) were analyzed without pretreatment. Feces were mixed with 9 volumes of bidistilled water using an Ultra Turrax blender. Triplicate 150 to $500 \mathrm{mg}$ samples were taken immediately after homogenizing and treated as described for organ tissue samples. The carcass was dissolved in 2 volumes 
of 1 mol/ $1 \mathrm{NaOH}$ by repeated incubation at $50^{\circ} \mathrm{C}$ for $1 \mathrm{~h}$ followed by incubation at room temperature for 4 h. Triplicate $500 \mathrm{mg}$ samples were treated as described for organ tissue samples. All samples were thouroughly mixed with $15 \mathrm{ml}$ Hionic Fluor. Radioactivity was determined after 1 hour of incubation at room temperature.

\section{Determination of specific activity of B-6 vitamers}

Approximately $1 \mathrm{~g}$ of liver or muscle tissue was pulverized under liquid nitrogen cooling, and mixed with exactly two wolumes of $0.25 \mathrm{~mol} / \mathrm{l}$ sucrose. After solubilizing for 1 h at $0-4{ }^{\circ} \mathrm{C}$ three volumes of $200 \mathrm{~g} / \mathrm{trichloroacetic} \mathrm{acid} \mathrm{(TCA)} \mathrm{were} \mathrm{added}$ with vigorous mixing. After incubating for $5 \mathrm{~min}$ in a shaking water bath at $37^{\circ} \mathrm{C}$, the samples were centrifuged for $15 \mathrm{~min}$ at $2000 \mathrm{~g}$ and room temperature. The clear supernatant was washed three times with two volumes of water-saturated diethyl ether. After the last extraction the diethyl ether residue was removed under a light nitrogen flow at $40^{\circ} \mathrm{C}$ (ca. $30 \mathrm{~min}$ ). Aliquots of the treated samples were stored at $-20^{\circ} \mathrm{C}$ until HPLC analysis for separation of the various B-6 vitamers. Urine was diluted threefold with bidistilled water on the day of HPLC analysis.

\section{HPLC conditions}

For separation of the various vitamin B-6 vitamers in liver and muscle samples we used a modification of the HPLC method by Coburn \& Mahuren [25]. A Nucleosil 5 SA cation exchange column $(10 \mu \mathrm{m} ; 4.6 \mathrm{~mm} \times 25 \mathrm{~cm})$ was used. A Milton Roy CM1000 solvent delivery system (Milton Roy Convp., Rochester, NY), capable of ternary gradient formation, was set at a flow rate of $1.0 \mathrm{ml} / \mathrm{min}$. A Perkin Elmer ISS100 injector (Perkin Elmer, Beaconsfield, Great Britain) was used to inject $150 \mu \mathrm{l}$ samples. Post-column reagent was prepared by adjusting the $\mathrm{pH}$ of a $0.7 \mathrm{~mol} / \mathrm{l}$ $\mathrm{NaH}_{2} \mathrm{PO}_{4}$ solution to 7.5 with $\mathrm{NaOH}$ (solid) and adding $1 \mathrm{~g} / \mathrm{l} \mathrm{NaHSO}$ just before use. Post-column reagent was added by means of an LKB 2115 Multiperpex pump (Pharmacia LKB, Uppsala, Sweden). A Perkin Elmer 204-A spectrofluorometer with $100 \mu \mathrm{l}$ flow cell, with the excitation wavelength set at $330 \mathrm{~nm}$ and the emission wavelength at $400 \mathrm{~nm}$, coupled to a Kipp BD41 recorder (Salm \& Kipp, Breukelen, Netherlands), was used for detection. Solvents and other chromatographic conditions were as described [25]. Concentrations of the various vitamin B-6 vitamers were calculated by comparing peak heights of samples with the corresponding peak heights of the standard solution, except for PLP. In liver samples and, to a lesser extent, in muscle samples the PLP peak in the HPLC chromatogram was disturbed by a highly fluorescent compound of unknown identity. A similar peak was observed by Bitsch \& Möller [26] when analyzing raw pork liver samples. Therefore, $200 \mu$ liver and muscle sample aliquots were treated with $35 \mathrm{U}$ of AP at room temperature for 30 min. PLP concentration was calculated by subtracting PL concentration without AP treatment from the corresponding PL concentration with AP treatment. Aliquots $(725 \mu \mathrm{l})$ of HPLC effluent were collected with an LKB 2211 Superrac fraction collector (Pharmacia LKB, Uppsala, Sweden) and were thoroughly mixed with $4 \mathrm{ml}$ 
Hionic Fluor. After incubation for $1 \mathrm{~h}$ at room temperature radionctivity was determined in all fractions.

For urine samples a different HPLC procedure was used because of the presence of many interfering compounds. Knauer columns $(4.6 \mathrm{~mm} \times 12.5 \mathrm{~cm})$ were slurrypacked with Hypersil ODS $3 \mu \mathrm{m}$ using methanol/water 1:1 at $40 \mathrm{MPa}$. Flow rate was set at $1.2 \mathrm{~m} / / \mathrm{min}$ of $0.1 \mathrm{~mol} / / \mathrm{KH}_{2} \mathrm{PO}_{4}$ containing $10 \mathrm{ml} / \mathrm{l}$ methanol and adjusted to $\mathrm{pH} 2.45$ with concentrated orthophosphoric acid $(850 \mathrm{~g} / \mathrm{l})$. No post-column reagent was used. Injection wolume was set at $100 \mu \mathrm{l}$, excitation wavelength at $320 \mathrm{~nm}$, and emission wavelength at $420 \mathrm{~mm}$. Concentration of 4-PA was calculated by comparing 4-PA peak heights with corresponding peak heights of a 4-PA standard solution. A $3.6 \mathrm{ml}$ fraction of HPLC effluent containing $\left[{ }^{14} \mathrm{C}\right] 4-\mathrm{PA}$ was collected. A $3.0 \mathrm{ml}$ aliquot was mixed thoroughly with $18 \mathrm{ml}$ Hionic Fluor. Radioactivity was determined after $1 \mathrm{~h}$ incubation at room temperature.

\section{Data analysis}

Urinary excretion data were fitted to a biexponential function $A_{1} \cdot \exp \left(-\lambda_{1} \cdot 1\right)+$ $\mathrm{A}_{2} \cdot \exp \left(-\lambda_{2} \cdot t\right)$ using a standard non-linear regression program (BMDP3R, BMDP Statistical Software, Los Angeles, $\mathrm{CA}$ ). $\mathrm{A}_{1}$ and $\mathrm{A}_{2}$ are the exponentiall constants, $\lambda_{1}$ and $\lambda_{2}$ the exponential coefficients of the derived function. Half-time corresponding to the derived $\lambda_{2}$, the final slope of the urinary excretion-time curve, is $t_{1 / 2}$, el. Other biokinetic parameters reported were calculated from the derived function as described by Shipley \& Clark [27], with ftr denoting the fractional turnover rate. Three different widely used biokinetic methods were used to calculate pool sizes. First, the amount of ${ }^{14} \mathrm{C}$ label dosed remaining to be excreted (ARE) was calculated at each time point. The resulting data were used to derive the biokinetic parameters summarized under 'ARE model'. Second, excretion rate of label into urine was calculated at midpoint time of the collection interval. From excretion rate data the pool sizes summarized under 'excretion rate model' were derived. Third, corresponding biokinetic parameters were derived from data on specific activity of 4-PA in selected urine samples $(1,2,3,5,7,14,18$ or 19,25 or 26,33 or 35 and 47 days after dosing); pool sizes are summarized under 'specific activity model'. Data are presented as mean $\pm S D$. Differences between age groups were evaluated by the Student's t-test. Probability levels $(P)<0.05$ were considered statistically significant.

\section{Results}

\section{Body and organ weights and vitamin B-6 concentration}

Body and organ weights of the animals used in experiments 1 and 2 are summarized in Table 1. Old rats showed significantly higher kidney, heart and brain weights and 
Table 1. Body and crgan weights of animals (mean $\mathrm{SD}, n=10$ ) used in experiments 1 and 2 .

\begin{tabular}{|c|c|c|}
\hline \multirow[t]{2}{*}{ Tissue } & \multicolumn{2}{|l|}{ Age } \\
\hline & 6 months & 31 months \\
\hline Total body $(\mathrm{g})$ & $345=18$ & $356 \pm 34$ \\
\hline Liver $(\mathrm{g})$ & $10.40=0.93$ & $11.56 \pm 2.59$ \\
\hline Kidrieys (g) & $2.11 \pm 0.19$ & $3.30 \pm 0.71$ \\
\hline Brain 6 g & $1.89=0.10$ & $2.02 \pm 0.11^{*}$ \\
\hline Heart $(\mathrm{g})$ & $1.03 \pm 0.08$ & $1.66 \pm 0.39^{\text {ta }}$ \\
\hline Lef gassirocnemius muscle $(\mathrm{g})$ & $2.49 \pm 0.19$ & $1.91 \pm 0.70^{\circ}$ \\
\hline Right gastrocnemius muscle (g) & $2.54 \pm 0.16$ & $1.86 \pm 0.72^{*}$ \\
\hline Carcass $(\mathrm{g})$ & $318 \pm 16$ & $330 \pm 32$ \\
\hline
\end{tabular}

${ }^{1}$ Different from 6-month values: * $P<0.025$, * $P<0.01$, * $P<0.005$.

Table 2. Tissue $\mathrm{B}-6$ vitamer concentration ( $m e a n \pm S D, n=10$ ) of animals used in experiments 1 and 2 .

\begin{tabular}{|c|c|c|}
\hline \multirow[t]{2}{*}{ B-6 vitamer } & \multicolumn{2}{|l|}{ Age } \\
\hline & 6 monuhs & 31 months \\
\hline \multicolumn{3}{|l|}{ Liver } \\
\hline PLP(nmol/g) & $24.2 \pm 6.7$ & $17.1 \pm 3.2^{* 1}$ \\
\hline PMP (nmol/g) & $41.5 \pm 6.3$ & $31.2 \pm 6.1$ \\
\hline $\mathrm{PL}(\mathrm{nmol} / \mathrm{g})$ & $4.9 \pm 1.6$ & $4.2 \pm 1.4$ \\
\hline 4-PA (nmol/g) & $0.6 \pm 0.2$ & $0.7 \pm 0.2$ \\
\hline PLP + PMP (nmol/g) & $65.7 \pm 12.1$ & $48.4 \pm 7.2^{5}$ \\
\hline PLP/PMP (nmol/nmol) & $0.58 \pm 0.12$ & $0.57 \pm 0.14$ \\
\hline \multicolumn{3}{|l|}{ Muscle } \\
\hline PLP (nmol/g) & $33.2 \pm 3.5$ & $17.9 \pm 8.4^{* * *}$ \\
\hline $\mathrm{PMP}$ (nmol/g) & $7.8 \pm 1.3$ & $7.6 \pm 2.3$ \\
\hline PLP + PMP (nmol/g) & $41.0 \pm 3.9$ & $25.5 \pm 9.7 *$ \\
\hline PLPFPMP (nmol/nmol) & $4.4 \pm 0.7$ & $2.4 \pm 1.1 \%$ \\
\hline
\end{tabular}

Different from the 6 -month values: $P<0.01$, * $P<0.005$.

significantly lower gastrocnemius muscle weights than young rats. B-6 vitamer concentrations measured in liver and muscle tissue are given in Table 2. Liver PLP and PMP as well as muscle PLP concentrations were significantly lower in old than in young rats. As a result, PLP + PMP concentration was lower in both liver and muscle tissue of old rats. The PLP/PMP ratio was lower in muscle tissue of old rats than of young rats. In liver tissue PLP/PMP ratio did not differ significantly between age groups. 
Table 3. Distribution of ${ }^{14} \mathrm{C}$ label (mean $\pm \mathrm{SD}, n=3$ ) after a single oral dose of $\left[{ }^{14} \mathrm{C} P \mathrm{PN}\right.$ in experiment 1.

\begin{tabular}{|c|c|c|c|}
\hline \multirow[t]{2}{*}{ Sample or tissue } & \multirow[t]{2}{*}{ Age (mo) } & \multicolumn{2}{|c|}{ Time after dosing } \\
\hline & & I diay & 47 days \\
\hline \multirow[t]{2}{*}{ Liver $(\%)$} & 6 & $16.22 \pm 1.03$ & $0.74 \pm 0.06$ \\
\hline & 31 & $12.74 \pm 1.08^{60 t}$ & $0.80 \pm 0.24$ \\
\hline \multirow[t]{2}{*}{ Kidneys $(\%)$} & 6 & $2.15 \pm 0.12$ & $0.110 \pm 0.012$ \\
\hline & 31 & $1.96 \pm 0.24$ & $0.133 \pm 0.042$ \\
\hline \multirow[t]{2}{*}{ Brain $(\%)$} & 6 & $0.492 \pm 0.097$ & $0.047 \pm 0.003$ \\
\hline & 31 & $0.354 \pm 0.048$ & $0.076 \pm 0.024$ \\
\hline \multirow[t]{2}{*}{ Heart $(\%)$} & 6 & $0.530 \pm 0.062$ & $0.033 \pm 0.002$ \\
\hline & 31 & $0.595 \pm 0.215$ & $0.056 \pm 0.019$ \\
\hline \multirow[t]{2}{*}{ Left gastrocnemius muscle (\%) } & 6 & $0.499 \pm 0.117$ & $0.181 \pm 0.008$ \\
\hline & 31 & $0.318 \pm 0.130$ & $0.065 \pm 0.052^{*}$ \\
\hline \multirow[t]{2}{*}{ Right gastrocnemius muscle (\%) } & 6 & $0.433 \pm 0.045$ & $0.183 \pm 0.010$ \\
\hline & 31 & $0.285 \pm 0.179$ & $0.057 \pm 0.041$ \\
\hline \multirow[t]{2}{*}{ Blood $\%$} & 6 & $0.057 \pm 0.021$ & $0.011 \pm 0.011$ \\
\hline & 31 & $0.128 \pm 0.080$ & $<\mathrm{dl}^{2}$ \\
\hline \multirow[t]{2}{*}{ Carcass $(\%)$} & 6 & $40.5 \pm 3.9$ & $12.0 \pm 0.1$ \\
\hline & 31 & $41.2 \pm 2.0$ & $8.8 \pm 2.0$ \\
\hline \multirow[t]{2}{*}{ Cumulative fecal excretion (\%) } & 6 & $1.48 \pm 1.26$ & $n^{3}$ \\
\hline & 31 & $0.81 \pm 0.64$ & nd \\
\hline \multirow[t]{2}{*}{ Cumulative urinary excretion (\%) } & 6 & $33.9 \pm 4.4$ & $65.1 \pm 1.9$ \\
\hline & 31 & $30.9 \pm 1.7$ & $72.8 \pm 2.0^{40}$ \\
\hline \multirow[t]{2}{*}{ Recovery $(\%)$} & 6 & $96.2 \pm 0.7$ & $77.1 \pm 2.7$ \\
\hline & 31 & $89.3 \pm 2.0^{*}$ & $82.7 \pm 1.3^{*}$ \\
\hline
\end{tabular}

' Different from the corresponding value at the age of 6 months: * $P<0.05$, ${ }^{* *} P<0.025$.

2 Below detection limit.

${ }^{3}$ Not determined.

\section{Experiment 1: Single oral dose of labeled $\mathrm{PN} \cdot \mathrm{HCl}$}

\section{Distribution of dose}

Distribution of ${ }^{14} \mathrm{C}$ label is presented in Table 3 as a percentage of the amount administered. All tissue and excreta examined showed the expected decrease (tissue) or increase (urine) of ${ }^{14} \mathrm{C}$ label with time. Significant differences between age groups were observed for liver, gastrocnemius muscle and urine. Liver ${ }^{14} \mathrm{C}$ content was lower in old rats than in young ones $24 \mathrm{~h}$ after dosing, but not 47 days after dosing. Average gastrocnemius muscle ${ }^{14} \mathrm{C}$ content was lower in old rats than in young ones, albeit not significantly 1 day after dosing. Total urinary excretion of ${ }^{14} \mathrm{C}$ label was higher in the old animals than in the young ones 47 days after dosing, but not $24 \mathrm{~h}$ after dosing.

On average, in young rats $76 \%$ of radioactivity in urine was present as 4-PA, in old rats this percentage was $67 \%$. As shown in Fig. 1, this age-related difference remained fairly constant up to 47 days after dosing. 


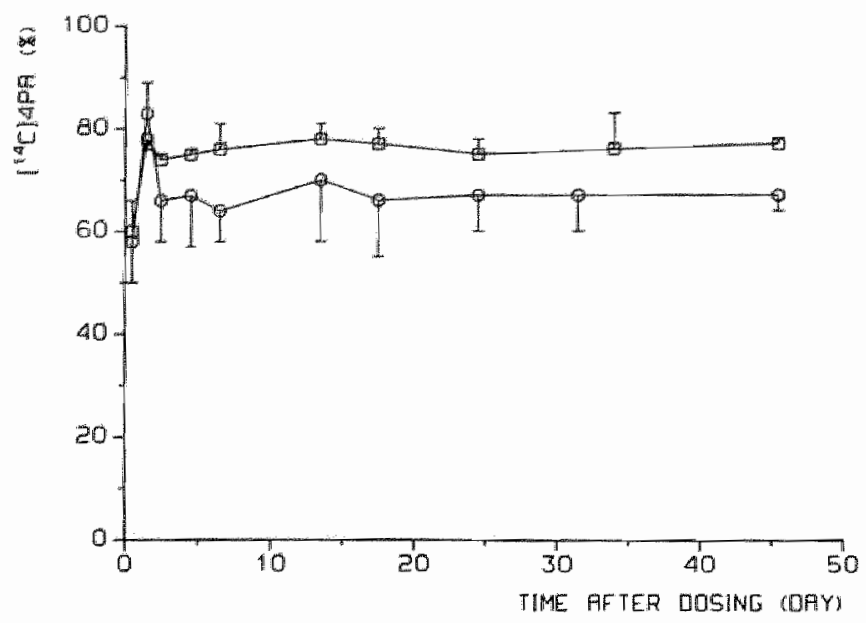

Fig, 1. Excretion of $\left.~_{14}{ }^{4} \mathrm{C}\right] 4-\mathrm{PA}$ into urine as a percentage of total urinary ${ }^{14} \mathrm{C}$ label present after a single oral dose of $1{ }^{4} \mathrm{CJPN}$ (experiment 1 ). Values are mean $\pm \mathrm{SD}, n=3$. Squares; young rats (6 months); circles: old rats (31 months).

Table 4. Vitamin B-6 vitamer specific activity (mean $\pm \mathrm{SD}, n=3$ ) after a single oral dose of $\left.\right|^{14} \mathrm{ClPN}$ in experiment 1.

\begin{tabular}{|c|c|c|c|}
\hline \multirow[t]{2}{*}{ B-6 vilamer } & \multirow[t]{2}{*}{ Age (mo) } & \multicolumn{2}{|c|}{ Time after dosing } \\
\hline & & 1 day & 47 days \\
\hline \multicolumn{4}{|l|}{ Liver } \\
\hline \multirow[t]{2}{*}{$\operatorname{PLP}(\mathrm{Bq} / \mathrm{mmol})$} & 6 & $23.3 \pm 1.5$ & $1.75 \pm 0.60$ \\
\hline & 31 & $25.5 \pm 20$ & $2.93 \pm 0.90$ \\
\hline \multirow[t]{2}{*}{$\operatorname{PMP}(\mathrm{Bq} / \mathrm{mmol})$} & 6 & $26.5 \pm 2.7$ & $1.35=0.32$ \\
\hline & 31 & $33.3 \pm 3.5$ & $2.67 \pm 0.75$ \\
\hline \multirow[t]{2}{*}{$\mathrm{PL}(\mathrm{Bq} / \mathrm{mmol})$} & 6 & $35.7 \pm 1.0$ & $4.15 \pm 0.9$ \\
\hline & 31 & $56.7 \pm 7.0^{5 x}$ & $7.5 \pm 2.2$ \\
\hline \multirow[t]{2}{*}{ 4-PA (Bq/mmol) } & 6 & $46+16$ & $<\mathrm{dl}^{2}$ \\
\hline & 31 & $48 \div 12$ & $<\mathbb{d}^{2}$ \\
\hline \multirow[t]{2}{*}{ PLP/PMP (ratio) } & 6 & $0.88 \pm 0.04$ & $1.27 \pm 0.20$ \\
\hline & 31 & $0.77 \pm 0.09$ & $1.11 \pm 0.18$ \\
\hline \multicolumn{4}{|l|}{ Musch } \\
\hline \multirow[t]{2}{*}{$\mathrm{PLP}(\mathrm{Bq} / \mathrm{mmol})$} & 6 & $3.2=0.5$ & $1.61 \pm 0.13$ \\
\hline & 31 & $6.7 \pm 4.3$ & $3.40+0.58^{*}$ \\
\hline \multirow[t]{2}{*}{ PMP ( $\mathrm{Bq} / \mathrm{m}$ mol) } & 6 & $1.0 \pm 4.0$ & $2.34 \pm 0.27$ \\
\hline & 31 & $13.5 \pm 2.7$ & $5.75 \pm 0.40^{\text {s.t. }}$ \\
\hline \multirow[t]{2}{*}{ PLP/PMP (ratio) } & 6 & $0.32 \pm 0.13$ & $0.68 \pm 0.12$ \\
\hline & 31 & $0.47 \pm 0.24$ & $0.59 \pm 0.08$ \\
\hline \multirow{3}{*}{$\begin{array}{l}\text { Last } 24 \text { h whine collection } \\
4 \mathrm{PA}(\mathrm{Bq} / \mathrm{mmol})\end{array}$} & & & \\
\hline & 6 & nd $^{3}$ & $1.08 \pm 0.12$ \\
\hline & 31 & nd & $1.68 \pm 0.73$ \\
\hline
\end{tabular}

Tifferent from the corresponding value at the age of 6 months: $P<0.025 * P<0.005$.

${ }^{2}$ Ritdioactivity 4-PA below detection limit in at least one sample. ${ }^{x}$ Not determined. 


\section{Specific activity}

Specific activities for liver (PLP, PMP, PL and 4-PA), gastrocnemius muscle (PLP and $\mathrm{PMP}$ ) and urine (4-PA) are given in Table 4. Although specific activity data suggest otherwise, ${ }^{14} \mathrm{C}$ label present in liver and muscle tissue was predominantly PLP and PMP (data not shown). The proportion of label present as PL, 4-PA, PM, and PN was relatively small ( $<10 \%$ for each vitamer) and showed large variation, especially 47 days after dosing.

\section{Biokinetic parameters}

Vitamin B-6 pool sizes calculated via three methods, ARE model, excretion rate model and specific activity model, are summarized in Table 5. Comparing the three models used, the ARE model resulted in the highest calculated amounts for vitamin B- 6 body pool, the excretion rate model gave the lowest body pool values and the specific activity model resulted in intermediary body pool sizes. Significant agerelated differences in body pool sizes were observed in the ARE model (old < young). The body pool size estimated using the specific activity model was the best approximation of the independently measured vitamin B-6 content of total rat body homogenate. Fig. 2 illustrates all biokinetic parameters derived from urinary 4-PA specific activity data. No significant age-related differences were observed for any parameter in the specific activity model.

Table 5. Calculated pool sizes (mean \pm SD) from urinary ${ }^{14} \mathrm{C}$ label excretion data after a single oral dose of $\left[{ }^{14} \mathrm{C}\right] \mathrm{PN}$ in experiment 1.

\begin{tabular}{|c|c|c|c|}
\hline \multirow[t]{2}{*}{ Tissue } & & \multicolumn{2}{|l|}{ Age } \\
\hline & & 6 months & 31 months \\
\hline \multicolumn{4}{|c|}{ ARE model $(n=3)$} \\
\hline Pool 1 & (umol) & $8.04 \pm 0.22$ & $4.98 \pm 1.02 * 2$ \\
\hline Pool 2 & (umol) & $5.51 \pm 0.13$ & $3.36 \pm 0.54^{* *}$ \\
\hline Body pool & (umoll) & $13.55 \pm 0.22$ & $8.34 \pm 1.54 *$ \\
\hline \multicolumn{4}{|c|}{ Excretion rate model $(n=3)$} \\
\hline Pool 1 & $(\mu \mathrm{mol})$ & $0.29 \pm 0.05$ & $0.26 \pm 0.05$ \\
\hline Pooll 2 & (umol) & $2.56 \pm 0.50$ & $2.26 \pm 0.65$ \\
\hline Body pool & $(\mu \mathrm{mol})$ & $2.86 \pm 0.53$ & $2.52 \pm 0.70$ \\
\hline \multicolumn{4}{|c|}{ Specific activity model $(n=3)$} \\
\hline Pool 11 & $($ (unol) & $1.63 \pm 0.110$ & $1.59 \pm 0.06$ \\
\hline Pool 2 & (umol) & $4.90 \pm 0.21$ & $5.49 \pm 0.99$ \\
\hline Body pool & $(\mu \mathrm{mol})$ & $6.53 \pm 0.30$ & $7.07 \pm 1.03$ \\
\hline \multicolumn{4}{|c|}{ Biochemical measuremerts $(n=6)$} \\
\hline Body pool & (umol) & $6.03 \pm 0.62$ & $5.87 \pm 0.58$ \\
\hline
\end{tabular}

\footnotetext{
1 Different from the corresponding walue at the age of 6 months: ${ }^{*} P<0.01,{ }^{* *} P<0.005$.
} 


\section{A: young rats}

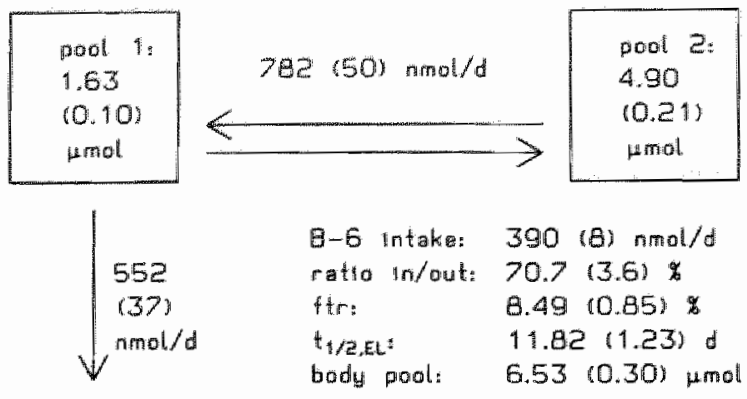

日: ald rats

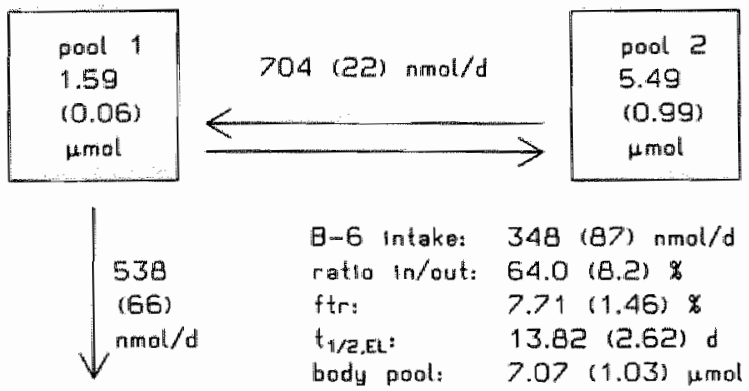

Fig. 2. Biokinetic model of vitamin B-6 derived from rat urinary 4-PA specific activity data after a single oral dose of $\left.\right|^{14} \mathrm{CJPN}$ (experiment 1 ). Values shown are mean (SD), $n=3$.

Experiment 2: Repeated oral doses of labeled $\mathrm{PN} \cdot \mathrm{HCl}$

The study design precluded calculation of level of significance; changes observed are therefore descriptive only.

Distribution of dose

Distribution of ${ }^{14} \mathrm{C}$ label among the various tissues and excreta after five daily doses of ${ }^{14} \mathrm{ClPN} \cdot \mathrm{HCl}$ is summarized in Fig. 3. The samples showed the expected decrease (tissue samples) or increase (excreta) in time except for gastrocnemius muscle tissue in which ${ }^{14} \mathrm{C}$ label content first showed a slight increase followed by a decrease. Percentage of ${ }^{14} \mathrm{C}$ label dosed recovered from muscle tissue and carcass was consistently lower in old rats than in young ones. Conversely, more ${ }^{14} \mathrm{C}$ label was excreted into urine by the old rats than by the young ones at all time points. In other tissue samples absolute differences between young and old rats were relatively small. 


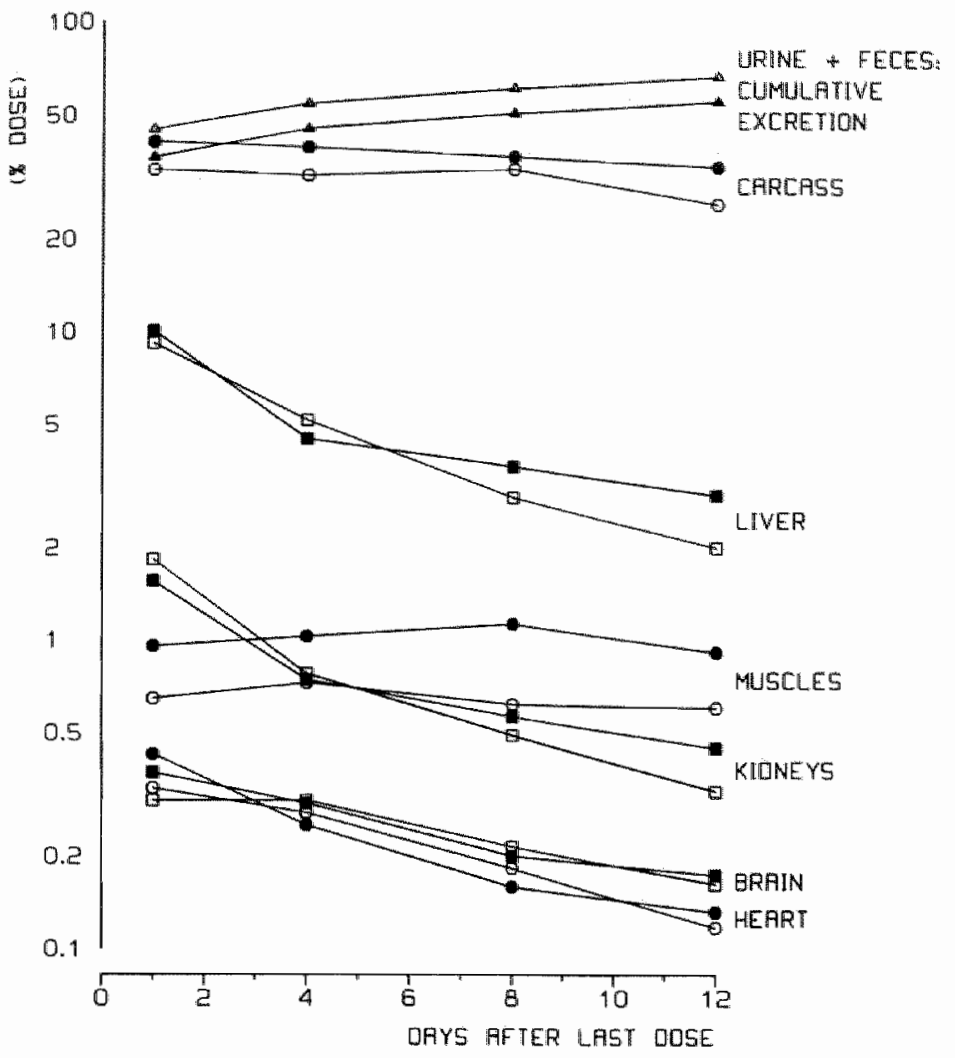

Fig. 3. Distribution of ${ }^{14} \mathrm{C}$ label (log scale) after 5 repeated daily oral doses of $\left.\right|^{14} \mathrm{C} P \mathrm{PN}$ (experiment 2 ). Closed symbols: young rats (6 months); open symbols: old rats ( 31 months). Each symbol represents one animal.

\section{Specific activity}

Specific activity data of liver and muscle B-6 vitamers are summarized in Fig. 4. PLP and PMP were the predominant ${ }^{14} \mathrm{C}$ labeled vitamers present, the proportion of ${ }^{14} \mathrm{C}$ label present as PL, PM, PN or 4-PA was $<10 \%$ for each vitamer (results not shown). Liver PLP and PMP specific activities decreased with time. Liver PL specific activity showed similar values and decrease with time as liver PLP and PMP specific activities. Liver 4-PA specific activity was consistently lower in old than in young animals. At 12 days after the last dose liver 4-PA specific activity was higher than specific activity of liver PLP, PMP or PL. Relevance of these observations may be obscured by the fact that the 4-PA and PL concentrations in liver tissue samples were low. The liver PLP/PMP specific activity ratio was lower for old than for young rats. The liver PLP/PMP specific activity ratio increased with time, from 0.93 to 1.14 in young and from 0.69 to 0.81 in old animals. This indicates that PMP specific activity decreased faster than PLP specific activity. Muscle specific activity values observed 

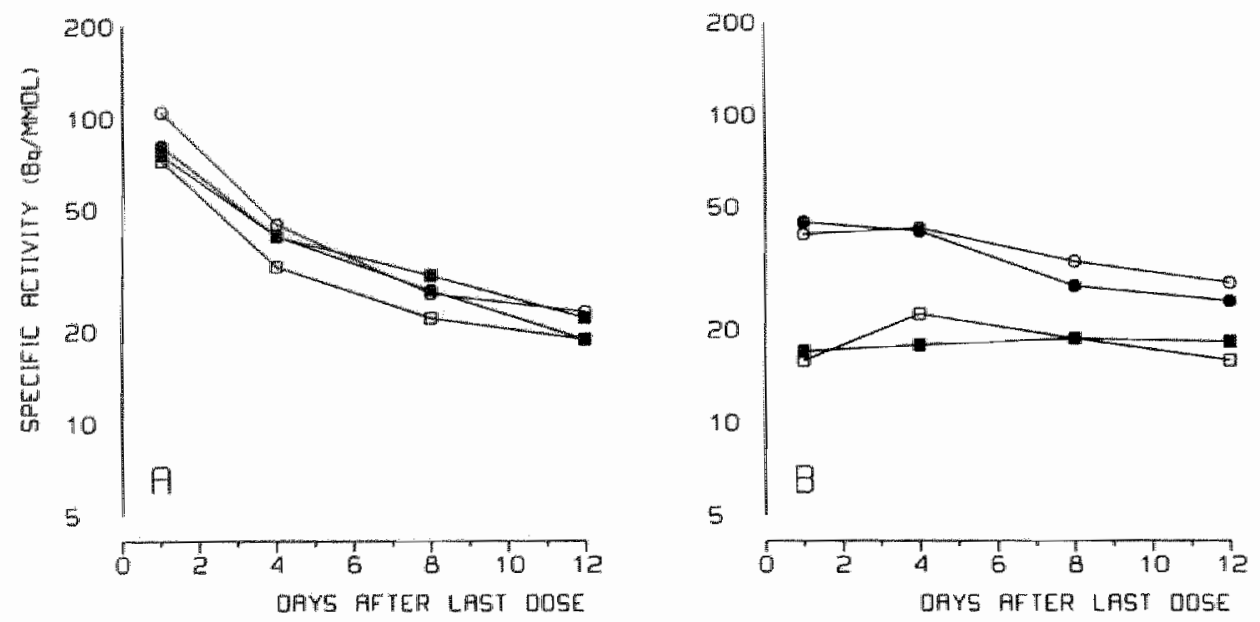

Fig. 4. Vitamin $B-6$ vitamer specific activity $\left(\log\right.$ scale) after 5 repeated oral doses of $\left[{ }^{14} \mathrm{C}\right] \mathrm{PN}$ (experiment 2). A, liver; B, gastrocnemius muscle; closed symbols, young rats (6 months); open symbols, old rats (31 months); squares, PLP; circles, PMP. Each symbol represents one animal.

were comparable between young and old rats. Muscle PLP specific activity was smaller than that of muscle PMP. Muscle PLP specific activity remained fairly constant, whereas that of muscle PMP decreased with time. As a result, the muscle PLP/PMP ratio increased with time, from 0.38 to 0.66 in young and similarly from 0.38 to 0.63 in old animals. 12 Days after the last dose liver and muscle specific activity values for all B-6 vitamers were comparable, except possibly for liver 4-PA.

\section{Discussion}

We have recently reported the effect of aging on vitamn B-6 vitamer content and on vitamin B-6 metabolizing enzyme activities in rats [15]. In the present experiment we used a more dynamic approach to study vitamin B-6 metabolism in a cohort of aging rats. Generally, results of the single oral $\left[{ }^{14} \mathrm{C}\right] \mathrm{PN}$ dose experiment (experiment 1 ) are supported by results of the repeated oral $\left[{ }^{14} \mathrm{C}\right] \mathrm{PN}$ dosing experiment (experiment 2 ). Repeated oral dosing was used to increase specific activity and thus detect changes in any vitamin B-6 body pool with slow turnover.

\section{Total body distribution of label}

Absorption of $\left[{ }^{14} \mathrm{C}\right] \mathrm{PN} \cdot \mathrm{HCl}$ administer ed orally was virtually complete in both young and old rats as only minor amounts of label were recovered from feces (Table 3). Because the percentage of ${ }^{14} \mathrm{C}$ label administered that was excreted into urine was higher for old than for young rats at 47 days after dosing, but not at 1 day after dosing, in experiment 1 , it was concluded that long-term total body retention of ${ }^{14} \mathrm{C}$ 
label was lower in the old than in the young animals. This was confirmed by the results obtained in the second experiment (Fig. 3). In experiment 2 the first sampling time was 5 days after the first $\left[{ }^{14} \mathrm{C}\right] \mathrm{PN} . \mathrm{HCl}$ dose. The proportion of ${ }^{14} \mathrm{C}$ label excreted into urine 1 day after the first dose was $25.6 \pm 4.6 \%$ (mean \pm SD) for the young and $29.2 \pm 3.4 \%$ for the old rats. These values compare well with those found in experiment 1 (Table 3). The observed age-related difference in ${ }^{14} \mathrm{C}$ label retention over a 47-day period was modest but may result in a relevant difference in total body vitamin $\mathrm{B}-6$ balance over llonger periods.

The larger amount of ${ }^{14} \mathrm{C}$ label excreted into urine (Table 3), combined with the lower percentage of ${ }^{14} \mathrm{C}$ label present as 4PA (Fig. 1) and the similar percentage of dose excreted as 4PA (approximately 50\%) in old versus young rats, suggest agerelated differences in urinary excretion of B-6 vitamers other than 4-PA. HPLC radiograms indicated the presence of three (minor) ${ }^{14} \mathrm{C}$-containing compounds with retention times different from the known B-6 vitamers in urine of both young and old rats. Unidentified metabolites of vitamin B-6 have been observed before in human plasma [28], but the subjects studied ingested high doses of vitamin B-6, more than $200 \mathrm{mg} \mathrm{PN} \cdot \mathrm{HCl}$ per day. The higher urinary ${ }^{14} \mathrm{C}$ label excretion in old versus young rats was probably net related to impaired kidney function, as no age-related decrease in kidney function was observed in an earlier experiment with healthy rats fed a similar diet [15]. Lower total body vitamin B-6 retention due to lower tissue binding capacity, for example to vitamin B-6-dependent apo-enzymes, of (active) vitamin B-6 vitamers with increasing age seems a more likely explanation.

The percentage of ${ }^{14} \mathrm{C}$ label present in gastrocnemius muscle tissue was consistently smaller in old than in young rats, which can at least partly be explained by the lower gastrocnemius muscle weight in the old rats (Table 1). Age-related differences in muscle tissue weight were however smaller than differences in ${ }^{14} \mathrm{C}$ label content (Table 3 and Fig. 3). Most of the ${ }^{14} \mathrm{C}$ label, in both young and old animals, was present in the carcass. In experiment 1,47 days after dosing, for young rats $90.6 \pm 1.0 \%$ was calculated to be present in the carcass (total body content $100 \%$ ), whereas for old rats this value was $89.1 \pm 2.8 \%$ (no significant age-related difference). In experiment 2 , from day 8 onwards, the carcass accounted for approximately $75 \%$ of ${ }^{14} \mathrm{C}$ label in both young and old rats. Labeled vitamin B-6 present in carcass most likely is located predominantly in muscle tissue. In experiment 1,47 days after dosing, the proportion of ${ }^{14} \mathrm{C}$ label remaining in carcass tended to be lower in the old rats than in the young ones (Table 3). This observation was confirmed in experiment 2 , with old rats showing lower values than young rats at all time points (Fig. 3).

In her study on senescent mice, Fonda et al. $[12,14]$ observed greater accumulation of labeled compounds in livers and brains of old animals than of young ones. Based on this observation, she suggested that the old mice were vitamin B-6- deficient. Contrary to results in these mice experiments, in our experimental animals ${ }^{14} \mathrm{C}$ accumulation in organs of old rats was never (significantly) higher than in organs of young rats. It should be noted, however, that the mice study of Fonda and 
colleagues was an experiment of much shorter duration (tissues were sampled up to 30 minutes after dosing) than ours.

\section{Disposition of label in liver and muscle tissue}

In both liver and musele tissue one day after (the last) dosing the ratio of ${ }^{14} \mathrm{ClPLP}$ to ${ }^{14} \mathrm{CJPMP}$ observed was lower than that of unlabeled PLP to unlabeled PMP present (Table 2). This resulted in a lower specific activity for PLP than for PMP, or a PLP/PMP specific activity ratio below unity (Table 4). This suggests that rate of uptake of external vitamin B-6 into tissue PLP is slower than into tissue PMP. Furthermore, the PLP/PMP specific activity ratio was higher at later tume points in both liver and muscle, in both experiments 1 and 2 (PMP specific activity decreased to a larger extent than PLP specific activity, suggesting that rate of elimination of tissue PLP into external vitamin B-6 is slower than that of tissue PMP). We therefore concluded that in both liver and muscle tissue PMP exchanges faster with external vitamin B-6 than tissue PLP. This conclusion is contradictory to observations in studies with non-labeled vitamin B-6: in liver tissue, vitamin B-6 is hypothesized to be compartmented into a slow (mostly mitochondrial PMP) and a fast (mostly cytosolic PLP) pool, the difference in exchange rate being governed by the predominant location of the B-6 vitamers [29-31]. On the other hand, our data confirm that muscle vitamin B-6 is a more slowly exchanging vitamin B-6 pool than liver vitamin B-6: specific activity values for PLP and PMP in liver tissue were higher than those in muscle tissue one day after (the last) dosing, suggesting a higher rate of uptake in liver, but decreased to similar values at the last day of sampling (Table 4 and Fig. 4, respectively), suggesting a higher rate of elimination from liver.

Age-related differences in vitamin B-6 metabolism in liver and muscle tissue were observed: in old animals less ${ }^{14}$ Clabel was present as PLP (in both liver and muscle tissue) or as PMP (liver tissue only) than in young rats. Similar age-related differences were observed for tissue concentrations of PLP and PMP (Table 2), resulting in comparable specific activity values for both age groups (Table 4 and Fig. 4). Age-related differences in vitamin B-6 metabolizing enzyme activities in both liver and muscle tissue have been reported, but were concluded not to be explained by the concurrently observed changes in tissue vitamin B-6 vitamer concentrations [15]. We postulated that organ tissue binding capacity for vitamin B-6 (PLP) was probably the main factor responsible for age-related differences in PLP and PMP concentrations. Therefore, age-related differences in binding capacity of $\left.\right|^{14} \mathrm{CJPLP}$ and ${ }^{14} \mathrm{C}$ PMP, rather than age-related differences in vitamin $\mathrm{B}-6$ metabolism per se, could be a causal factor. A lower tissue vitamin B-6 binding capacity would explain the smaller amounts of $\left[{ }^{14} \mathrm{C}\right.$ PLP and $\left[{ }^{14} \mathrm{C}\right] \mathrm{PMP}$ observed in old rat liver and muscle tissues than in tissues from young animals, and it would explain higher ${ }^{14} \mathrm{C}$ label excretion (lower body retention) in old rats than in young ones. 
When urinary excretion data of ${ }^{14} \mathrm{C}$ label administered are used to calculate vitamin B-6 body pools, several assumptions have to be made. First, because of the biexponential shape of the corresponding time curves a two-compartment (central, 1, and peripheral, 2) open model is used to describe excretion data. Second, when calculating derived parameters, dosing is assumed to take place into compartment 1 and excretion is assumed to occur from compartment 1 exclusively. These assumptions apply to all three models used to derive biokinetic parameters. A third assumption intrinsic to both the ARE model and the excretion rate model is that the rate of excretion equals the rate of dietary B-6 intake. This is not necessarily true because the animals might well have been in positive or negative vitamin $\mathrm{B}-6$ balance. Vitamin B-6 balance is not assumed in the specific activity model, but instead specific activity of 4-PA in urine is assumed to be representative of specific activity of (all vitamers present in) compartment 1 . As illustrated in Table 4, specific activity of urinary 4-PA at day 47 was found to be somewhat below values observed for PLP and PMP in liver and muscle tissue, the predominant B-6 vitamers present. Although compartment 1 in the specific activity model not necessarily contains either liver or muscle tissue, this finding might indicate the latter assumption to be incorrect, too.

Theoretically, all three models should provide similar biokinetic parameter values. Only the ARE model shows a tendency to artificially smoothen curves due to the way ARE values are calculated: dose administered minus (increasing) amounts excreted. Therefore, with the ARE model important irregularities in excretion, if present, can easily be overlooked. Neither excretion rate nor urinary 4-PA specific activity data are smoothened before curve fitting. Corresponding time curves are probably a better reflection of the process examined than the ARE data. Although all three models are widely used in kinetic research, the specific activity model is concluded to be most appropriate to our experiment based on theoretical grounds.

To validate the models vitamin B-6 body pools calculated were compared with those obtained via an independent (biochemical) estimation: measurement of vitamin B-6 content in total body homogenates from male Wistar rats of the same cohort (Table 5). Compared to these amounts, values calculated for vitamin B-6 body pool in the specific activity model resulted in the best approximation of the actual values. Furthermore, the ARE model can be discarded on other grounds: pool 1 is calculated to be larger than pool 2, i. e. more vitamin B-6 is present in the 'fast' compartment 1 than in the 'slow' compartment 2 , which is not in agreement with the postulated presence of a large peripheral vitamin B-6 pool with slow tumover. The biokinetic parameters derived by means of the specific activity model are not suggestive of an age-related difference in long-term body retention, because values calculated for $t_{1 / 2}$, ell and for excretion rate are not significantly different (Fig. 2). Data on distribution of ${ }^{14} \mathrm{C}$ label dosed (especially urinary excretion of ${ }^{14} \mathrm{C}$ label at later time points), however, suggested a lower long-term body retention in old than in young rats (Table 3 and Fig. 3). 
The vitamin B-6 biokinetic parameters derived using the specific activity model (Fig. 2) deserve further attention. First, the vitamin B-6 body pool calculated was not significantly lower in old animals than in young ones, indicating that in the old rats the vitamin B-6 body pool was not depleted. The same conclusion was drawn based on ${ }^{14}$ C label distribution over different body compartments and over liver and muscle B-6 vitamers. Second, the calculated amount of vitamin B-6 leaving the body in any form per day is larger than vitamin B-6 intake with feed. This could imply that all animals, both young and old, were in negative vitamin B-6 balance or that another exogenous vitamin B-6 source, supplying $30-40 \%$ of total vitamin B-6 intake, was utilized. The most likely candidate for an exogenous vitamin B-6 source appears to be vitamin B-6 synthesized by gut microflora. However, experiments by Coburn et al. [23] on conventional and germfree rats provided no evidence for a role of the intestinal microflora in the synthesis of vitamin B-6 compounds available to the host under conditions of adequate vitamin B-6 supply. Third, judged from the high $t_{1 / 2, \mathrm{el}}$ values calculated, a slow peripheral vitamin B-6 body compartment was included in the model. This compartment is generally supposed to consist of muscle tissue vitamin B-6, which is mostly PLP bound to the enzyme glycogen phosphorylase [ 30 , 32]. In mice muscle PLP half-life was calculated to be approximately 9 days [33]. This compares well with the (somewhat larger) values found for $t_{1 / 2}$, el in our experimental rats (Fig. 2).

As was stated by Coburn [34], the biokinetic approach appears to be a valuable tool in vitamin B-6 research. Some hypotheses postulated in (more static) biochemical experiments were independently verified in our experiments. On the other hand, the hypothesis that PLP is a faster exchanging tissue vitamin B-6 pool than PMP was disclaimed. Our finding that PMP in liver and muscle tissue is exchanging faster with external vitamin B-6 than liver and muscle tissue PLP necessitates independent verification (e.g. by new biochemical experiments). The major age-related difference observed in $\left[{ }^{14} \mathrm{C}\right] \mathrm{PN} \cdot \mathrm{HCl}$ disposition after oral dosing was a lower ${ }^{14} \mathrm{C}$ label retention in old than in young rats. Distribution of label retained (among tissues and among B-6 vitamers) was not different, only absolute ${ }^{14} \mathrm{C}$ levels were lower in old than in young rats. Lower tissue $\left[{ }^{14} \mathrm{CJPLP}\right.$ and ${ }^{14} \mathrm{C} \mid \mathrm{PMP}$ content and higher urinary ${ }^{14} \mathrm{C}$ label excretion can probably be explained by a lower protein-binding capacity, in old compared to young rats, of active vitamin B-6 vitamers formed.

\section{References}

1. Rose CS, György P, Butler M, Andres R, Norris AH, Shock NW, Tobin J, Brin M, Spiegell H. Age differences in vitamin B-6 status of 617 men. Am J Clin Nutr 1976:29: 847-53.

2. Hamfelt A, Söderhjelm L. Vitamin B-6 and aging. In: JE Leklem, RD Reynolds, Eds. Clinical and Physiological Applications of Vitamin B-6. Current Topics in Nutrition and Disease, Vol. 19. New York: Alan R. Liss, 1988: 95-107.

3. Löwik MRH, wan den Berg H, Westenbrink S, Wedel M, Schrijver J, Ockhuizen Th. Doseresponse relationships regarding vitamin B-6 in elderly people: a nationwide nutritionall survey (Dutch Nutritional Surveillance System). Am J Clin Nutr 1989;50: $391-9$. 
4. Vir SC, Love AHG. Vitamin B-6 status of the hospitalized aged. Am I Clin Nutr 1978,31: 1383-91.

5. Garry PJ, Goodwin JS, Hunt WC, Hooper EM, Leonard AG. Nutritional status in ahealty elderly population: dietary and supplemental intakes. Am J Clin Nutr 1982,36:319-31.

6. Guilland JC, Bereksin Reguig B. Lequeu B, Moreau D, Klepping J, Richard D. Evaluation of pyridoxine intake and pyridoxine status among aged institutionalised people. Internat I Vit Nutr Res $1984 ; 54: 185-93$.

7. Löwik MRH, Westenbrink S, Hulshof KFAM, Kistemaker C. Hermus RJ. Nutriton and aging: dietary intake of "apparently healthy" elderly (Dutch Nutrition Survellance System). I Am Coll Nutr 1989;8: $347-56$.

8. Hoom RKJ. Flikweert JP. Westerink D. Vitamin B-1, B-2 and B-6 defictencies in gertatric patients, measured by coenzyme stimulation of enzyme activities. Clin Chim Acta 1975.61: $151-62$.

9. Lee CM, Leklem JE. Differences in vitamin B-6 status indicator responses between young and middle-aged women fed constant diets with wo levels of vitamin B-6. Am J Clin Nutr 1985,42 : $226-34$.

10. Kant AK, Moser-Veillon PB, Reynolds RD. Effect of age on changes in plasma, erythrocyte, and urinary B-6 vitamers after an oral vitamin B-6 load. Am J Clin Nutr 1988:48: 1284-90.

11. Leclerc J. Thiamine, riboflavine et vitamine B-6 tissulaires chez le rat age. II. Influence d'une surcharge vitaminique administrée dans le régime sur l'excrétion des vitamines et sur lours taux tissulaires. Ann Nutr Alim 1978;32:753-63,

12. Fonda ML. Eggers DKm Mehta R. Vitamin B-6 metabolism in the livers of young adult and senescent mice. Exp Gerontol 1980;15:457-63.

13. Fonda ML \& Eggers DK. Vitamin B-6 metabolism in the blood of young adult and senescent mice. Exp Gerontol 1980;15:465-72.

14. Fonda ML, Eggers DK. Auerbach S \& Fritsch L. Vitamin B-6 metabolism in the brains of young adult and senescent mice. Exp Gerontol 1980;15:473-9.

15. Bode W, Mocking JAJ, van den Berg. Influence of age and sex on vitamin B-6 vitamer distribution and on vitamin B-6 metabolizing enzymes in Wistar rats. J Nutr 1991;121:318-29.

16. Bode W, van den Berg H. Pyridoxal-5'-phosphate and pyridoxal biokinetics in aging Wistar rals. Exp Gerontol (in press).

17. Cox SH, Murray A, Boone IU. Metabolism of tritum-labeled pyridoxine in rats. Proc Soc Exp Biol Med 1962;109: 242-4.

18. Tillotson JA, Sauberlich HE, Baker EM, Canham JE. Use of carbon-14 labelled vitamins in human nutrition studies: pyridoxine. In: Proceedings of the Seventh International Congress of Nutrition, Vol. 5, Physiology and Biochemistry of Food Components. Oxford: Pergamon Press 1966: $554-7$.

19. Johansson S, Lindstedi S, Register U, Wadström L. Studies on the metabolism of labeled pyridoxine in mant. Am J Clin Nurr 1966:18:185-96.

20. Shane B. Vitamin B-6 and blood. In: Human Vitamin B-6 Requirements. Washington DC: National Acadenyy of Sciences, 1978:111.28.

21. Shane B. Vitamin B-6 metabolism and turnover in the ethanol-fed rat. J Nutr 1982;112;610-8.

22. Coburn SP, Mahuren JD. Erbelding WF. Townsend DW, Hachey DL, Klein PD. Masurement of vitamin $B \times 6$ kinetics in vivo using chronic administration of labeled pyridoxine. In: Chemical and Blological Aspects of Vitamin B-6 Catalysis, Part A. New York: Alan R. Liss, 1984: 43-54.

23. Coburn SP, Mahuren dD, Wostmann BS, Snyder DL, Townsend DW. Rale of intestinal microflora in the metabolism of vitamin B-6 and 4 -deoxypyridoxine examined using germfree guinea pigs and rats. J Nutr 1989;119:181-8.

24. van den Berg H, Bogaards JJP. Vitamin B-6 metabolism in the pregnant rat: effect of progesterone on the (re)distribution in maternal vitamin B-6 slores. IN Nutr 1987:117: 1866-74

25. Coburn SP. Mahuren JD. A versatile cation-exchange procedure for measuring the seven major forms of vitamin B-6 in biological samples. Anal Biochem 1983;129:310-7.

26. Bitsch. Möller I. Analysis of B-6 vitamers in foods using a modified high-performance liquid chromatographic method. J Chromatog 1989:463:207-11.

27. Shipley RA, Clark RE. Tracer Methods for In Viwo Kinetics. Theory and Applications. New York: Academic Press, 1972:21.31. 
28. Edwards P, Liu PWS, Rose GA. Liquid chromadographic studies of witam Bn B-6 metabolism in man. Clin Chim Acta 1990;190: 67-80.

29. van den Berg H. Bogaards JJP. Sinkeldam EJ, Schreurs WHP. Effect of different levels of vitamin $\mathrm{B}_{4} 6$ in the diet of rats on the content of pyridoxamine -5' phosphate and pyridoxal-5. phosphate in the liver. Int I Vit Nutr Reg, 1982:52:407-16.

30. Bosron WF, Veitch RL. L.umeng L, Li T-K. Subcellular localization and identification of pyridoxal-5" phosphate-binding protein in rat liver. J Biol Chem 1978:253: 1488-92.

31. Lui $A$, Lumeng $L$, Li T $-K$. Stability of B-6 vitamers and location of pyridoxal-P hydrolase activity in isolated rat liver mitochondria. Fed Proc 1980;39:558 (abstract).

32. Black AL, Guirard BM, Snell EE. Increased muscle phosphorylase in rats fed high level of Witamin B-6. J Nutr 1977:107: 1962-8.

33. Cookson EJ, Beynon RJ. Further evaluation of cofactor as a turnover label for glycogen phosphorylase. Int J Biochem 1989:21:975-82.

34. Coburn C. Location and tumover of vitamin B-6 pools and vitamin B-6 requirements of humans. Ann NY Acad Sci 1990;585: 77-85. 


\section{Part IV. Influence of graded vitamin B-6 intake}





\section{Effects of graded vitamin B-6 intake in a one-year feeding study in Wistar rats: Biochemical and functional consequences}

Wilhelmina Bode, Johannes A.J. Mocking and Henk van den Berg

\section{Abstract}

The influence of a long-term low vitamin B-6 intake was studied in male and female Wistar rats aged 13 months, fed purified diets containing $<0.5$, ca. 3 , or ca. $6 \mathrm{mg}$ pyridoxine $\cdot \mathrm{HCl}$ per $\mathrm{kg}$ from weaning, animals fed the $6 \mathrm{mg} / \mathrm{kg}$ diet being the control group. Characteristics studied were vitamin B-6 status parameters, vitamin B-6 concentrations and activities of vitamin B-6 metabolizing enzymes in various body compartments (plasma, liver, brain, gastrocnemius muscles, heart and kidneys). Vitamin B-6 dependent enzymes were studied in plasma, erythrocytes, liver and gastrocnemius muscle. Furthermore, plasma clinico-chemical parameters, kidncy function and hematological characteristics were assessed. In all body compartments examined pyridoxal-5'-phosphate (PLP) and pyridoxamine-5'-phosphate (PMP) contents were significantly lower in animals fed the $<0.5 \mathrm{mg} / \mathrm{kg}$ diet, but not in animals fed the $3 \mathrm{mg} / \mathrm{kg}$ diet, than in control animals. Plasma PLP level was affected more by lower vitamin B-6 intake than tissue PLP or PMP content. Brain tissue PLP and PMP concentrations were relatively spared. Both gastrocnemius muscle PLP concentration and glycogen phosphorylase (GP) activity were lower in the $<0.5 \mathrm{mg} / \mathrm{kg}$ rats than in controls. Average muscle PLP attributable to GP binding did not differ significantly among diet groups. It is concluded that muscle PLP level is probably regulated by the PLP-binding capacity of GP. Of the vitamin B-6 dependent liver enzymes examined, the low-cofactor-affinity enzymes tyrosine aminotransferase and serine dehydratase present in cytoplasma were affected more by lower vitamin B-6 intake than the high-cofactor-affinity enzyme asparate aminotransferase predominantly present in mitochondria. Red blood cell characteristics indicated microcytic hypochromic anemia in the $<0.5 \mathrm{mg} / \mathrm{kg}$ diet group only. In the same dict group white blood cells showed a significant shift towards less lymphocytes and more neutrophils, concomitantly with a thymic involution due to lymphocyte depletion in the thymic cortex. 


\section{Introduction}

Aging seems to be accompanied with changes in vitamin B-6 status parameters and, probably, also by changes in vitamin B-6 metabolism. This aging effect is most pronounced for the vitamin B-6 status parameter plasma pyridoxal-5'-phosphate (PLP) concentration, which has been observed to be lower at higher age in both rat and man [1-3]. Data reported on urinary 4-pyridoxic acid (4-PA) excretion, tryptophan (TRP) loading and enzyme activiation tests are less conclusive $[4,5]$. In a recent study in men of different age groups no significant differences in baseline erythrocyte PLP content and urinary 4-PA excretion were observed, albeit plasma PLP level was highest in the youngest age group [6]. A comparable study in pre- and postmenopausal women, however, indicated an age-related increase in (relative) 4-PA excretion [7]. Studies on pyridoxine supplementation of elderly people indicate that a daily supplement of 2-20 mg is generally sufficient to obtain values of commonly used vitamin B-6 status parameters within the younger adult reference range (for a review, see [8]).

Age-related changes in vitamin B-6 status parameters and/or vitamin B-6 metabolism may be related to changes in vitamin B-6 intake, vitamin B-6 absorption, body composition or organ function. Whether changes in vitamin B-6 metabolism have consequences with respect to vitamin B-6 requirements and whether changes in vitamin B-6 status parameters are causally related to some of the complications and diseases associated with old age (hypertension, cognitive function loss, cardiovascular disease) remains to be established.

To study the age-related changes in vitamin B-6 metabolism in more detail we started a life-long rat experiment with animals kept under standardized conditions fed a vitamin B-6 adequate diet [3]. In a parallel experiment rats were fed a diet with a lower vitamin B-6 content from weaning to study the functional consequences of a long-term deficient or marginal vitamin B-6 status. In this report we describe the effects on biochemical and functional parameters of a 12 -month feeding experiment with rats fed diets containing approximately $10 \%, 50 \%$ or $100 \%$ [9] of the recommended vitamin B-6 level from weaning. Results will be used as background data, to compare the effects of aging on vitamin B-6 metabolism with those of a longterm low vitamin B-6 intake.

\section{Materials and methods}

\section{Animal handling}

Newly weaned male and female Wistar rats (Bor:WISW (SPF Cpb)) were obtained from F. Winkelmann, Borche, FRG, and assigned to three diel groups. Starting at an age of four weeks, the animals were fed ad libitum a purified diet containing $250 \mathrm{~g}$ casein and either $0.3 \pm 0.2 \mathrm{mg}(n=55), 3.2 \pm 0.1 \mathrm{mg}(n=120)$ or $5.9 \pm 0.9 \mathrm{mg}$ 
$(n=120)$ pyridoxine $\cdot \mathrm{HCl}(\mathrm{PN} \cdot \mathrm{HCl})$ per $\mathrm{kg}$. For a detalled composition of the experimental diets see Bode and van den Berg [10]. The experimental groups were named after the amount of vitamin B-6 present in the diet $(<0.5,3$ and $6 \mathrm{mg} / \mathrm{kg}$, respectively), the $6 \mathrm{mg} / \mathrm{kg}$ diet group being the control group. The animals were housed in groups of five in stainless steel cages in a well ventilated room at $23 \pm 1{ }^{\circ} \mathrm{C}$, with a relative humidity of $50 \pm 10 \%$, and a $12 \mathrm{~h}$ light-dark cycle. All animals had free access to tap water. Body weight (BW) and food intake were monitored longitudinally for all rats.

\section{Experimental protocol}

At the age of 13 months 6 rats of all sex and diet groups were randomly selected from different cages and housed individually in stainless steel metabolism cages. Individual food intake was monitored for four days, and urine (on dry ice) and feces were collected. After the last collection, blood was collected for hematological analysis by tail puncture. Three days later, a TRP load test (200 mg TRP per kg BW administered in a single intragastric dose) was performed. At least seven days later the animals were sacrificed by exsanguination. Blood was collected from the abdominal aorta under diethyl ether anesthesia and stored on ice until. centrifugation. Liver, heart, kidneys, brain, as well as both gastrocnemius muscles were resected and weighed. All animals were subject to gross post-mortem and histopathological examinations, and routine plasma clinico-chemical parameters were measured to assess global health status. Tissue homogenates were prepared as described before $[11,12]$ and stored at $-80^{\circ} \mathrm{C}$. Total homogenates were used for measurement of tissue vitamin B-6 content, protein and enzyme activities were assayed in $2000 \mathrm{~g}$ supernatant. The experimental protocol was approved by the Institute's Committee for Research on Experimental Animals.

\section{Method's of analysis}

PLP in plasma, PLP, pyridoxamine-5"-phosphate (PMP), PL-kinase (ATP:pyridoxal5'-phosphotransferase; EC 2.7.1.35) activity and PMP-oxidase (pyridoxamine-5'phosphate:oxidoreductase; EC 1.4.3.5) activity in tissue samples and urinary 4-PA were measured as described earlier [12]. PLP and PMP (after nonenzymatic transamination with glyoxylic acid to PLP) were assayed radioenzymatically, 4-PA was measured by HPLC. PL-kinase assay in liver, brain and kidney was performed at $\mathrm{pH} 7$, in muscle and heart at $\mathrm{pH}$ 9. PLP-hydrolase (orthophosphoric-monoester phosphohydrolase, alkaline optimum; EC 3.1.3.1) activity in tissue samples was assessed according to Lumeng \& Li [13]. PL-oxidase (aldehyde:oxygen oxidoreductase; EC 1.2.3.1) and PL-dehydrogenase (aldehyde:NADP oxidoreductase, EC 1.2.1.4) activities were measured at $\mathrm{pH} 7$ and $\mathrm{pH} 9.5$, respectively, using a modification of the method by Merrill et al. [14]; in our assays 4-PA formed was measured by HPLC. Glycogen phosphorylase (GP; 1, 4- $\alpha$-Dglucan:orthophosphate-a-glucosyltransferase; EC 2.4.1.1) activity was assayed using 
a modification of the method of Cori et al. [15] except that in our assay NADPH appearance was followed spectrophotometrically. Tissue protein was measured using the Coomassie Brilliant Blue protein assay, with BioRad reagent 500-0006 (BioRad, Munich, FRG), according to the manufacturers' instructions. Erythrocyte enzyme activities were assayed on a Hitachi 705 analyzer (Hitachi, Tokyo, Japan); erythrocyte aspartate aminotransferase (EASAT; L-aspartate:2-oxoglutarate aminotransferase; EC 2.6.1.1) activity was measured using kit 704075 from Boehringer (Boehringer Mannheim, FRG) according to the manufacturers' instructions, erythrocyte glutathione reductase (EGR; NAD(P)H:oxidizedglutathione oxidoreductase; EC 1.6.4.2) activity was measured according to Bayoumi \& Rosalki [16]. Urinary xanthurenic acid (XA) concentration was assayed as described by Schrijver et al. [17], urinary kynurenic acid (KA) as described by Krstulovic \& Matzura [18]. Liver alanine aminotransferase (ALAT; L-alanine:2oxoglutarate aminotransferase, EC 2.6.1.2) activity was measured with reagent kit 704083 from Boehringer. Liver aspartate aminotransferase (ASAT) activity was analyzed with kit 704075 from Boehringer. Liver tyrosine aminotransferase (TAT; tyrosine: $\alpha$-ketoglutarate aminotransferase; EC 2.6.1.5) activity was measured by a modification of the method by Diamondstone [19]. Liver serine dehydratase (SDH; L-serine hydro-lyase, deaminating; EC 4.2.1.13) activity was evaluated by measuring pyruvate formed according to Dakin \& Dudley [20]. Liver enzyme ALAT, ASAT, TAT and SDH activities were measured with and without addition of excess PLP (+PLP and -PLP, respectively). All four methods of liver enzyme analysis were modified to be performed with a PU 8745 UV/Vis Spectrophotometer (Philips/Pye Unicam, Cambridge, England). Plasma clinico-chemical parameters and urinary creatinine and urea levels were measured on a Cobas-Bio centrifugal analyzer (Hoffmann-La Roche, Basel, Switzerland) by standard methods according to the manufacturers' instructions. Hematology parameters were assessed by standard methods on a Coulter Counter ZF (Coulter Electronics, England) according to the manufacturers'.instructions (red and white blood cells), on a Sysmex platelet counter PL-110 (Toa Medical Electronics, Japan) according to the manufacturers' instructions (thrombocytes), by microscopic examination of blood smears stained with methylene blue (reticulocytes), and by microscopic examination of blood smears stained according to Pappenheim (differential white blood cell count).

\section{Statistical analysis}

Analysis of variance was performed on all data using a $2 \times 3$ factorial design with the factors sex (male or female) and diet $(<0.5,3$ or $6 \mathrm{mg} / \mathrm{kg}$ ) using the GENSTAT statistical package. A probability level $(P)<0.05$ was considered statisticatly significant. For all parameters investigated the standard error of the differences between means (SED) is given in the tables. T-values can be calculated by dividing the difference between two means by the corresponding SED. 


\section{Rationale}

The biochemical and functional effects of a low vitamin B-6 intake have been studied before. Most studies, however, refer to relatively short-term effects (feeding studies of less than 2 months duration) or to vitamin B-6 deficiency induced with the vitamin B-6 antagonist 4'-deoxypyridoxine (DOP). Observations by Coburn et al. suggest that the in vivo effects of DOP may involve more than simple competitive inhibition of vitamin B-6 dependent enzymes [21]. In our study, both male and female rats were studied in a long-term (12 months) feeding experiment in which vitamin B-6 status was manipulated via the vitamin B-6 level in the experimental diets.

The rat is a frequently used and well validated model in vitamin B-6 metabolism research [22]. Vitamin B-6 metabolic pathways and regulation mechanisms of humans and rats compare well $[14,22]$. Recommended daily vitamin B-6 intake, expressed per $\mathrm{kg}$ of $\mathrm{BW}$, is much higher in rats than in man (approximately $0.5 \mathrm{mg} / \mathrm{kg}$ versus $0.02 \mathrm{mg} / \mathrm{kg}$ ). Relative to protein intake, vitamin B-6 recommendations differ less strongly: $16 \mu \mathrm{g} / \mathrm{g}$ protein for man, $25-30 \mu \mathrm{g} / \mathrm{g}$ protein for rats. In (severe) vitamin B-6 deficiency both humans and rats show characteristic hematologic and neurologic symptoms and impaired cellular and humoral immune responses $[23,24]$. From a more practical point of view, rat diets are more easily standardized with respect to nutrient composition than the human diet to induce an isolated vitamin B-6 deficiency for prolonged periods of time. In man, a complete and isolated vitamin B-6 deprivation is unlikely to occur. The use of suboptimal levels of dietary vitamin B-6 was therefore preferred over the use of a rat diet completely devoid of vitamin $\mathrm{B}-6$.

\section{General health status}

Body weight and food intake. All animals showed the largest BW gain during the first 2-3 months of the experiment, followed by a smaller, steady BW increase (Fig. 1). The 3 and $6 \mathrm{mg} / \mathrm{kg}$ diet groups showed a steadily increasing BW up to 13 months of age, the $<0.5 \mathrm{mg} / \mathrm{kg}$ animals appeared to reach their maximum BW at an age of $8-9$ months. For both males and females, BW differed significantly between the $<0.5 \mathrm{mg} / \mathrm{kg}$ diet on the one hand and the 3 and $6 \mathrm{mg} / \mathrm{kg}$ diets on the other as soon as one week after starting the feeding experiment. Food intake was significantly lower for the $<0.5 \mathrm{mg} / \mathrm{kg}$ diet group by this time as well. Food intake remained fairly constant for all experimental groups throughout the study. At an age of 13 months food intake, measured as cage mean, was $87.5 \pm 8.8 \mathrm{~g} / \mathrm{week}, 101.4 \pm 6.0 \mathrm{~g} / \mathrm{week}$ and $101.8 \pm 7.0 \mathrm{~g} /$ week for the male rats fed $<0.5,3$ and $6 \mathrm{mg} / \mathrm{kg}$, and $64.3 \pm 3.2 \mathrm{~g} / \mathrm{week}$, $77.0 \pm 5.3 \mathrm{~g} /$ week and $78.1 \pm 3.1 \mathrm{~g} /$ week for the female rats fed $<0.5,3$ and $6 \mathrm{mg} / \mathrm{kg}$, respectively (mean \pm SD). Food intake never differed significantly between animals 


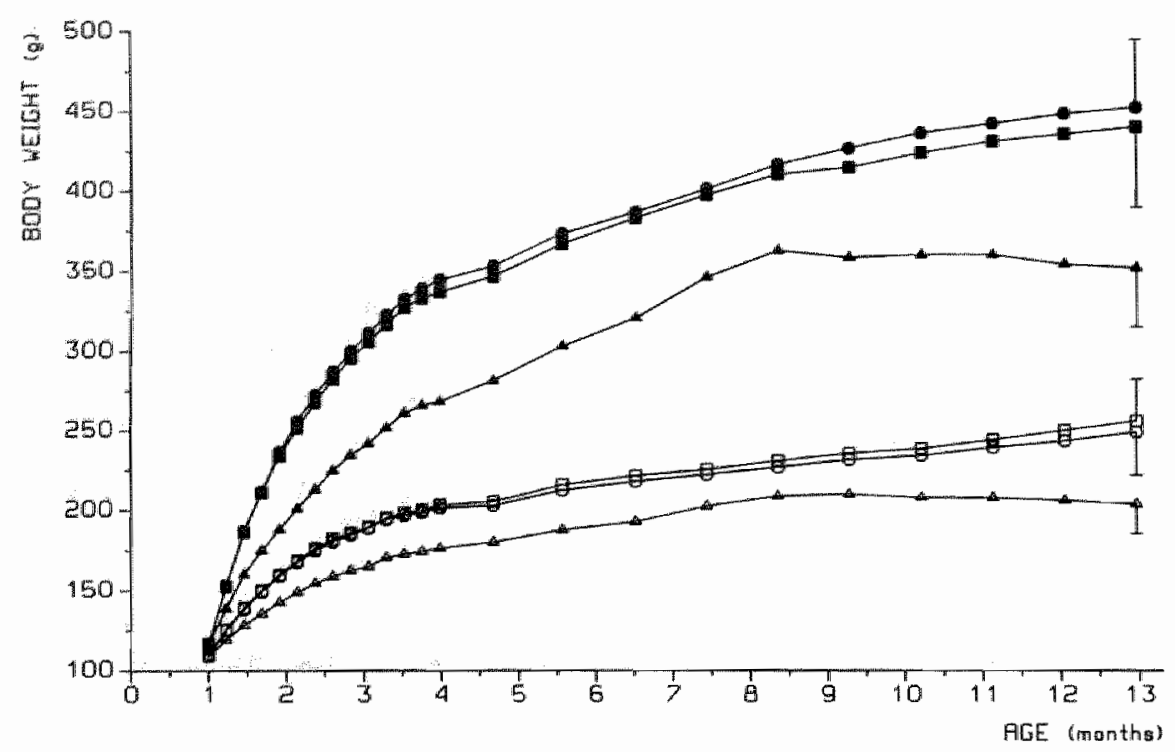

Fig. 1. Mean BW of the total cohort of Wistar rats fed a purified diet with graded levels of witamin B-6. Closed symbols, males; open symbols, females; squares, <0.5 mg/kg diet; circles, $3 \mathrm{mg} / \mathrm{kg}$ diet; triangles, $6 \mathrm{mg} / \mathrm{kg}$ diet. For clarity sake, SD values are indicated at an age of 13 months only.

fed the $3 \mathrm{mg} / \mathrm{kg}$ diet and those fed the $6 \mathrm{mg} / \mathrm{kg}$ diet. Daily food intake expressed per $\mathrm{kg} \mathrm{BW}$ showed a different sex-and diet-related pattern, with female rats showing higher food intake than males, but without significant diet differences. Values found for male rats were $35.6 \pm 3.6 \mathrm{~g} / \mathrm{kg} \mathrm{BW}, 32.2 \pm 1.9 \mathrm{~g} / \mathrm{kg} \mathrm{BW}$ and $32.2 \pm 2.3 \mathrm{~g} / \mathrm{kg} \mathrm{BW}$, for female rats $45.2 \pm 2.3 \mathrm{~g} / \mathrm{kg} \mathrm{BW}, 44.3 \pm 3.1 \mathrm{~g} / \mathrm{kg} \mathrm{BW}$ and $43.7 \pm 1.8 \mathrm{~g} / \mathrm{kg} \mathrm{BW}$ $(<0.5,3$ and $6 \mathrm{mg} / \mathrm{kg}$ diet, respectively).

Clinical signs. At an age of 13 months all animals fed the $<0.5 \mathrm{mg} / \mathrm{kg}$ diet showed rough, fuzzy fur and loss of hair. Most of these animals also showed atypical dermatitis around the nose and on the front paws (acrodynia), males generally being more affected than females. Lower body weight in combination with the observed skin abnormalities suggest a severe vitamin B-6 deficiency. However, mortality rate was not higher for the $<0.5 \mathrm{mg} / \mathrm{kg}$ diet than for the $3 \mathrm{mg} / \mathrm{kg}$ and the $6 \mathrm{mg} / \mathrm{kg}$ diets: survival was $>95 \%$ for all experimental groups. Animals were observed and handled daily by trained technicians; abnormal behavior was not noted.

Organ weights. Observations on organ weights and relative organ weights (as percent of $\mathrm{BW}$ ) are presented in Table 1 . Although BW of the $<0.5 \mathrm{mg} / \mathrm{kg}$ diet group was lower than that of control rats, absolute organ tissue weights did not differ between diet groups, except for heart weight. Relative heart weight, however, showed no significant diet-related difference. Sex-related differences in (relative) organ weights observed were as expected on the basis of sex-related differences in BW. 
Protein concentration. PLP is involved as cofactor in many amino acid metabolism reactions. Therefore, protein content of various body compartments was measured. Organ tissue protein content was significantly influenced by dietary vitamin B-6 level in muscle tissue only, (male) $<0.5 \mathrm{mg} / \mathrm{kg}$ diet rats showing lower values than

Table 1. Organ weights and tissue protein content.

\begin{tabular}{|c|c|c|c|c|c|c|c|c|}
\hline \multirow[t]{2}{*}{ Parameter } & \multirow[t]{2}{*}{ Sex ${ }^{1}$} & \multicolumn{3}{|c|}{ Diet $(\mathrm{mg} / \mathrm{kg} \mathrm{PN} \cdot \mathrm{HCl})$} & \multirow[t]{2}{*}{ SED } & \multicolumn{3}{|c|}{ Significance ${ }^{2}$} \\
\hline & & $<0.5$ & 3 & 6 & & diet & $\operatorname{sex}$ & dice $x \operatorname{sex}$ \\
\hline \multicolumn{9}{|l|}{ Liver } \\
\hline \multirow{2}{*}{$\begin{array}{l}\text { Weight } \\
(\mathrm{g})\end{array}$} & $\mathrm{M}$ & 12.62 & 12.58 & 12.48 & 0.88 & $N S^{\prime}$ & $<0.001$ & NS \\
\hline & $F$ & 6.34 & 6.95 & 7.41 & & & & \\
\hline \multirow{2}{*}{$\begin{array}{l}\text { Relative weight } \\
(\% \text { of } \mathrm{BW})\end{array}$} & M & 3.47 & 2.97 & 2.97 & 0.17 & 0.019 & NS & $\mathrm{NS}$ \\
\hline & $\mathbb{F}$ & 3.19 & 3.04 & 3.09 & & & & \\
\hline \multirow{2}{*}{$\begin{array}{l}\text { Protein } \\
\qquad(\mathrm{mg} / \mathrm{g})\end{array}$} & M & 124.5 & 138.2 & 129.2 & 4.6 & NS & 0.002 & 0.045 \\
\hline & $\mathrm{F}$ & 140.3 & 137.7 & 141.7 & & & & \\
\hline \multicolumn{9}{|c|}{ Gastrocnemius muscle (left and right) } \\
\hline \multirow{4}{*}{$\begin{array}{l}\text { Weight } \\
\text { (g) } \\
\text { Relative weight } \\
(\% \text { of } \mathrm{BW})\end{array}$} & $\mathrm{M}$ & 4.76 & 5.19 & 5.23 & 0.34 & $\mathrm{NS}$ & $<0.001$ & NS \\
\hline & F & 2.61 & 2.97 & 3.30 & & & & \\
\hline & M & 1.33 & 1.23 & 1.25 & 0.10 & NS & NS & NS \\
\hline & $F$ & 1.32 & 11.31 & 1.38 & & & & \\
\hline \multirow{2}{*}{$\begin{array}{l}\text { Protein } \\
\qquad(\mathrm{mg} / \mathrm{g})\end{array}$} & $\mathrm{M}$ & 45.8 & 50.11 & 50.0 & 1.5 & 0.006 & 0.002 & NS \\
\hline & $\mathbb{F}$ & 50.2 & 53.0 & 51.9 & & & & \\
\hline \multicolumn{9}{|l|}{ Heart } \\
\hline \multirow{2}{*}{$\begin{array}{l}\text { Weight } \\
\text { (g) }\end{array}$} & $\mathrm{M}$ & 1.099 & 1.309 & 1.238 & 0.073 & 0.026 & $<0.001$ & NS \\
\hline & $F$ & 0.847 & 0.923 & 0.919 & & & & \\
\hline \multirow{2}{*}{$\begin{array}{l}\text { Relative weight } \\
(\% \text { of BW })\end{array}$} & $M$ & 0.306 & 0.309 & 0.295 & 0.020 & NS & $<0.001$ & NS \\
\hline & $\mathrm{F}$ & 0.430 & 0.403 & 0.382 & & & & \\
\hline \multirow{2}{*}{$\begin{array}{l}\text { Protein } \\
(\mathrm{mg} / \mathrm{g})\end{array}$} & M & 59.5 & 61.0 & 60.5 & 2.7 & NS & NS & NS \\
\hline & $F$ & 60.0 & 61.6 & 62.0 & & & & \\
\hline \multicolumn{9}{|l|}{ Brain } \\
\hline \multirow{2}{*}{$\begin{array}{l}\text { Weight } \\
\text { (g) }\end{array}$} & $\mathrm{M}$ & 2.094 & 2.111 & 2.070 & 0.067 & $\mathrm{NS}$ & $<0.001$ & $\mathrm{NS}$ \\
\hline & $F$ & 1.875 & 1.861 & 1.878 & & & & \\
\hline \multirow{2}{*}{$\begin{array}{l}\text { Relative weight } \\
(\% \text { of } \mathrm{BW})\end{array}$} & $M$ & 0.582 & 0.500 & 0.493 & 0.030 & $<0.001$ & $<0.001$ & NS \\
\hline & $F$ & 0.948 & 0.820 & 0.787 & & & & \\
\hline \multirow{2}{*}{$\begin{array}{l}\text { Protein } \\
(\mathrm{mg} / \mathrm{g})\end{array}$} & $M$ & 34.8 & 35.6 & 36.1 & 1.5 & NS & 0.048 & NS \\
\hline & $\mathrm{F}$ & 36.6 & 37.6 & 37.8 & & & & \\
\hline \multicolumn{9}{|c|}{ Kidney (left and right) } \\
\hline \multirow{2}{*}{$\begin{array}{l}\text { Weight } \\
\text { (g) }\end{array}$} & $\mathrm{M}$ & 2.71 & 2.78 & 2.68 & 0.16 & NS & $<0.001$ & $\mathrm{NS}$ \\
\hline & $F$ & 1.75 & 1.86 & 2.00 & & & & \\
\hline \multirow{2}{*}{$\begin{array}{l}\text { Relative weight } \\
(\% \text { of } \mathrm{BW})\end{array}$} & M & 0.749 & 0.656 & 0.636 & 0.038 & 0.006 & $<0.001$ & $\mathbb{N S}$ \\
\hline & $F$ & 0.887 & 0.818 & 0.835 & & & & \\
\hline \multirow{2}{*}{$\begin{array}{l}\text { Protein } \\
(\mathrm{mg} / \mathrm{g})\end{array}$} & M & 70.1 & 75.8 & 76.6 & 2.9 & MS & NS & 0.047 \\
\hline & $\mathrm{F}$ & 75.4 & 71.7 & 73.3 & & & & \\
\hline
\end{tabular}

M, male: F, female; SED, standard error of the difference; $N S_{4}$ not significant.

2 ANOVA using factors diet ( $<0,5,3$ and $6 \mathrm{mg} \mathrm{PN}$. HCl per $\mathrm{kg}$ diet) and sex (M, F). 
Table 2. Plasria dinical chemistry parameters.

\begin{tabular}{|c|c|c|c|c|c|c|c|c|}
\hline \multirow[t]{2}{*}{ Parameter } & \multirow[t]{2}{*}{$\operatorname{Sex} x^{1}$} & \multicolumn{3}{|c|}{ Diet $(\mathrm{mg} / \mathrm{kg} \mathrm{PN} \cdot \mathrm{HCl})$} & \multirow[t]{2}{*}{$S E D^{\prime}$} & \multicolumn{3}{|c|}{ Significance 2} \\
\hline & & $<0.5$ & 3 & 6 & & dilet & $\operatorname{sex}$ & diet $\times$ sex \\
\hline \multirow{2}{*}{$\begin{array}{l}\text { Total protein } \\
(g / 1)\end{array}$} & $M$ & 61.4 & 62.7 & 62.8 & \multirow[t]{2}{*}{1.6} & \multirow[t]{2}{*}{$<0.001$} & \multirow[t]{2}{*}{ NS } & \multirow[t]{2}{*}{0.002} \\
\hline & $\mathrm{F}$ & 57.9 & 65.4 & 68.1 & & & & \\
\hline \multirow{2}{*}{$\begin{array}{l}\text { Albumin } \\
\text { (i/l) }\end{array}$} & M & 31.9 & 32.0 & 32.1 & \multirow[t]{2}{*}{1.5} & \multirow[t]{2}{*}{0.003} & \multirow[t]{2}{*}{$<0.001$} & \multirow[t]{2}{*}{0.006} \\
\hline & $F$ & 31.4 & 37.2 & 38.5 & & & & \\
\hline \multirow{2}{*}{$\begin{array}{l}\text { Creatinin } \\
(\mu \text { mol/l })\end{array}$} & M & 60.6 & 64.6 & 63.0 & \multirow[t]{2}{*}{3.4} & \multirow[t]{2}{*}{ NS } & \multirow[t]{2}{*}{0.013} & \multirow[t]{2}{*}{ NS } \\
\hline & $F$ & 56.3 & 60.2 & 56.1 & & & & \\
\hline \multirow{2}{*}{$\begin{array}{l}\text { Urca } \\
(\text { minol/ })\end{array}$} & M & 6.56 & 5.98 & 5.79 & \multirow[t]{2}{*}{0.40} & \multirow[t]{2}{*}{ NS } & \multirow[t]{2}{*}{ NS } & \multirow[t]{2}{*}{0.018} \\
\hline & $\mathrm{F}$ & 5.39 & 6.06 & 6.24 & & & & \\
\hline \multirow{2}{*}{$\begin{array}{l}\text { Inorg. phosphate } \\
(\mathrm{mmol} / \mathrm{l})\end{array}$} & M & 1.09 & 1.03 & 1.03 & \multirow[t]{2}{*}{0.16} & \multirow[t]{2}{*}{ NS } & \multirow[t]{2}{*}{0.002} & \multirow[t]{2}{*}{ NS } \\
\hline & $F$ & 1.22 & 1. 34 & 1.49 & & & & \\
\hline \multirow{2}{*}{$\begin{array}{l}\text { Cholesterol } \\
\text { (mmol/l) }\end{array}$} & M & 2.98 & 3.22 & 3.54 & \multirow[t]{2}{*}{0.37} & \multirow[t]{2}{*}{ NS } & 0.003 & NS \\
\hline & $F$ & 2.45 & 2.64 & 2.60 & & & & \\
\hline Bilirubin & M & 1.71 & 2.04 & 1.69 & 0.19 & 0.015 & NS & NS \\
\hline$(\mu \mathrm{mol} / \mathrm{l})$ & $F$ & 1.47 & 1.97 & 2.10 & & & & \\
\hline Alkal phosphatase & $M$ & 131 & 107 & 118 & 17 & 0.046 & NS & NS \\
\hline act. (UM) & $F$ & 122 & 88 & 88 & & & & \\
\hline ALAT & $\mathrm{M}$ & 10.5 & 25.3 & 29.1 & 5.7 & $<0.001$ & NS & NS \\
\hline$(\mathrm{U} / 1)$ & $F$ & 8.7 & 30.4 & 37.9 & & & & \\
\hline$A S A T$ & M & 39.8 & 52.3 & 57.6 & 8.1 & 0.014 & NS & $\mathrm{NS}$ \\
\hline (U/1) & $\mathbb{F}$ & 39.7 & 57.8 & 53.1 & & & & \\
\hline Fasting gucose 3 & $\mathrm{M}$ & 4.13 & 3.78 & 3.77 & 0.26 & NS & NS & NS \\
\hline$(\mathrm{mmol} / \mathrm{l})$ & $F$ & 3.77 & 4.05 & 3.67 & & & & \\
\hline
\end{tabular}

$1 \mathrm{M}$, male; F, female; SED, standard error of the difference; NS, not significant.

${ }^{2}$ ANOVA using factors diet $\left(<0.5,3\right.$ and $6 \mathrm{mg} \mathrm{PN}^{\mathrm{N}} \mathrm{HCl}$ per $\mathrm{kg}$ diet) and $\operatorname{sex}(\mathrm{M}, \mathrm{F})$.

${ }^{3}$ Measured after a 24 -hour fast, in blood obtained by tail puncrure.

controls (Table 1). Plasma total protein concentration (male and female rats) and plasma albumin level (female rats only) was lower in the $<0.5 \mathrm{mg} / \mathrm{kg}$ diet group than in control rats (Table 2). No definitive conclusions regarding the possible detrimental effect of decreased vitamin B-6 intake on protein synthesis or turnover could be drawn from these limited data. Some sex-related differences were observed: female rats had a significantly higher protein level in liver and gastrocnemius muscle tissue and a significantly higher plasma albumin concentration than males fed the same diel.

Kidney function. In order to rule out detrimental influences of inadequate renal function on vitamin B-6 turnover, kidney functioning was evaluated in the experimental animals. No significant difference among diet groups was observed for either urine concentration capacity during a $16-\mathrm{h}$ water deprivation period or glomular filtration rate. 
Vitamin B-2 status. One of the enzymes involved in vitamin B-6 metabolism from PN (in feed) to PLP is PMP-oxidase, a flavin mononucleotide (FMN) dependent enzyme. Riboflavin deficiency might interfere with the proper utilization of $\mathrm{PN}$ and in this way (partially) cause lower PLP levels. However, all rat diets wete formulated to be adequate with respect to riboflavin. EGR activity coefficient (EGR-AC), a widely used riboflavin status parameter, was measured to rule out a deficient riboflavin status in the vitamin B-6 manipulated animals. EGR-AC values were not indicative of inadequate riboflavin nutriture in any diet group and ranged from 1.1 to 1.3 for all animals.

\section{Vitamin B-6 status parameters}

Observations on vitamin B-6 status parameters are summarized in Table 3. The animals fed the $<0.5 \mathrm{mg} / \mathrm{kg}$ diet had values significantly different from those of

Table 3. Vitamin $B-6$ status parameters.

\begin{tabular}{|c|c|c|c|c|c|c|c|c|}
\hline \multirow[t]{2}{*}{ Parameter } & \multirow[t]{2}{*}{$\operatorname{Sex}^{1}$} & \multicolumn{3}{|c|}{ Diet $(\mathrm{mg} / \mathrm{kg} \mathrm{PN} \cdot \mathrm{HCl})$} & \multirow[t]{2}{*}{ SED } & \multicolumn{3}{|c|}{ Significance? } \\
\hline & & $<0.5$ & 3 & 6 & & diet & $\operatorname{sex}$ & diet $x \operatorname{sex}$ \\
\hline \multicolumn{9}{|l|}{ Plasma } \\
\hline \multirow{2}{*}{$\begin{array}{l}\text { PLP } \\
\text { (nmol/l) }\end{array}$} & M & 29 & 282 & 350 & 30 & $<0.001$ & $<0.001$ & $<0.001$ \\
\hline & $F$ & 39 & 306 & 557 & & & & \\
\hline \multicolumn{9}{|l|}{ Urine } \\
\hline \multirow{2}{*}{$\begin{array}{l}\text { 4-PA excretion } \\
(\mathrm{nmol} / \mathrm{d})\end{array}$} & $M$ & 3.5 & 94 & 212 & 15 & $<0.001$ & $<0.001$ & $<0.001$ \\
\hline & $F$ & 2.3 & 39 & 93 & & & & \\
\hline \multirow{2}{*}{$\begin{array}{l}\text { 4-PA excretion } \\
\text { (\% PN intake) }\end{array}$} & M & 71.4 & 53.0 & 60.8 & 7.6 & $<0,001$ & $<0,001$ & NS: \\
\hline & $\mathrm{F}$ & 63.7 & 33.8 & 30.7 & & & & \\
\hline \multicolumn{9}{|l|}{ Erythrocytes } \\
\hline \multirow{2}{*}{$\begin{array}{l}\text { EASAT } \\
\text { (U/mmol Hb) }\end{array}$} & M & 95 & 569 & 617 & 51 & $<0.001$ & NS & NS \\
\hline & $F$ & 150 & 617 & 625 & & & & \\
\hline \multirow[t]{2}{*}{ EASAT-AC } & $M$ & 3.39 & 1. 3 & 1.09 & 0.15 & $<0.001$ & $<0.001$ & $<0.001$ \\
\hline & $\mathrm{F}$ & 2.38 & 1.09 & 1.08 & & & & \\
\hline \multicolumn{9}{|c|}{ TRP load test (uninary excretion of TRP netabolines) } \\
\hline \multirow{2}{*}{$\begin{array}{l}\text { XA excretion -TRP } \\
(\mu \mathrm{mol} / \mathrm{d})\end{array}$} & $\mathrm{M}$ & 4.00 & 0.77 & 0.80 & 0.42 & $<0.001$ & $<0.001$ & $<0.001$ \\
\hline & $F$ & 0.57 & 0.13 & 0.22 & & & & \\
\hline \multirow{2}{*}{$\begin{array}{l}\text { XA excretion + TRP } 3 \\
(\mu \mathrm{mol} / \mathrm{d})\end{array}$} & $\mathrm{M}$ & 41.7 & 0.88 & 0.93 & 3.48 & $<0.001$ & NS & NS \\
\hline & $\mathrm{F}$ & 33.9 & 1.13 & 1.21 & & & & \\
\hline \multirow{2}{*}{$\begin{array}{l}\text { KA excretion -TRP } \\
\text { (finol/d) }\end{array}$} & M & 0.21 & 0.48 & 0.48 & 0.05 & $<0.001$ & NS & $<0.001$ \\
\hline & $\mathrm{F}$ & 0.24 & 0.26 & 0.56 & & & & \\
\hline \multirow{2}{*}{$\begin{array}{l}\text { KA excretion + TRP } 3 \\
(\mu \text { mol } / d)\end{array}$} & $M$ & 4.0 & 0.77 & 0.92 & 1.50 & $<0.001$ & $<0.001$ & $<0.001$ \\
\hline & $F^{\prime \prime}$ & 14.4 & 1.88 & 3.12 & & & & \\
\hline
\end{tabular}

$1 \mathrm{M}$, male; $\mathrm{F}$, female; SED, standard error of the difference; $\mathrm{NS}$, not significant.

2 ANOVA using factors diet $(<0.5,3$ and $6 \mathrm{mg}$ PN. HCl per $\mathrm{kg}$ diet $)$ and sex $(\mathrm{M}, \mathrm{F})$.

${ }^{3}$-TRP: wilhout an oral TRP load, basal urinary excretion; + TRP, after an oral TRP ioad, corrected for basal urinary excretion. 
controls for all parameters measured: lower plasma PLP levels, lower absolute urinary 4-PA excretion, higher relative urinary 4-PA excretion (as percent of dietary vitamin B-6 intake), higher urinary XA and KA excretion after TRP loading, lower EASAT activity and higher EASAT-AC values, all suggesting an overtly deficient vitamin B-6 status. Significant differences between rats fed the $3 \mathrm{mg} / \mathrm{kg}$ diet and those fed the $6 \mathrm{mg} / \mathrm{kg}$ diet were observed for plasma PLP concentration and absolute urinary 4.PA excretion only, which parameters are expected to be influenced by (recent) vitamin B-6 intake. The more functional parameters of vitamin B-6 status, EASAT activity and EASAT-AC, and results of the TRP loading test suggested that vitamin B-6 requirement of the animals studied were met with a diet containing only $3 \mathrm{mg} \mathrm{PN}$. HCl per $\mathrm{kg}$ (or $12 \mu \mathrm{g} \mathrm{PN} \cdot \mathrm{HCl}$ per g protein). This observation is in agreement with results of earlier studies $[25-27]$.

Some sex-related differences in vitamin B-6 status parameters were observed. Female rats showed significantly higher plasma PLP levels, lower absolute and relative urinary 4-PA excretion and lower EASAT-AC. Furthermore, the female

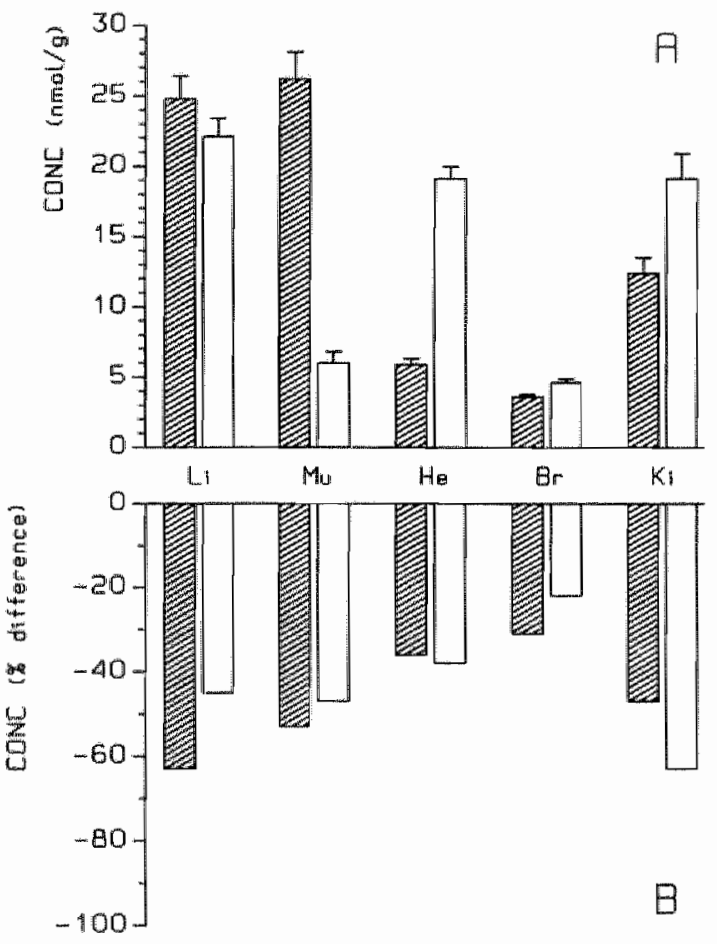

Fig. 2. PLP and PMP concentrations in liver (Li), gastrocnemius musde (Mu), heart (He), brain ( $\mathrm{Br}$ ) and kidney $(\mathrm{Ki})$ tissue. Shaded bars, PLF concentration; open bars, PMP concentration. A, mean PLP and PMP concentrations (and SED) of various tissues from male and female control rats $(n=12)$; $\mathrm{B}$, difference (\%) in tissue PLP and PMP concentrations between diet groups $<0.5 \mathrm{mg} / \mathrm{kg}$ and $6 \mathrm{mg} / \mathrm{kg}$ (control). $P<0.001$ for both PLP and PMP' in all tissues examined. 
rats' urinary excretion pattern of $\mathrm{XA}$ and $\mathrm{KA}$ differed from that of males, both with and without TRP loading. Sex-related differences in excretion of TRP metabolites can be expected, because kynureninase (EC 3.7.1.3), one of the enzymes involved in the oxidative pathway of TRP, is inhibited competitively by estrogen conjugates [28].

\section{Vitamin B-6 distribution}

Fig. 2 summarizes observations on tissue PLP and PMP concentrations of animals fed the $<0.5 \mathrm{mg} / \mathrm{kg}$ diet and those fed the $6 \mathrm{mg} / \mathrm{kg}$ diet. In all organ tissues examined PLP and PMP levels as well as PLP + PMP content (values not shown) were significantly lower in the $<0.5 \mathrm{mg} / \mathrm{kg}$ diet group than in control animals. B-6 vitamer concentrations in tissues of animals fed the $3 \mathrm{mg} / \mathrm{kg}$ diet were not significantly different from those fed the $6 \mathrm{mg} / \mathrm{kg}$ diet (data not shown).

Both PLP and PMP levels differed markedly between tissues. Furthermore, the PMP/PLP concentration ratio showed a wide range, from $>3$ in heart, $1-2$ in kidney, brain and liver, to $<0.3$ in gastrocnemius muscle. Diet-related differences in tissue PMP/PLP concentration ratio were significant for liver and kidney: in animals fed the $<0.5 \mathrm{mg} / \mathrm{kg}$ diet liver PMP/PLP concentration ratio was significantly higher and kidney PMP/PLP concentration ratio significantly lower than in corresponding controls. In a short-term feeding experiment, van den Berg et al. calculated a higher liver PMP/PLP concentration ratio in vitamin B-6 deficient than in control rats [11], because liver PLP level was lowered to a larger extent than liver PMP level with decreased vitamin B-6 intake. Higher preservation of tissue PMP than tissue PLP was also observed for liver, kidney, brain, muscle, heart, spleen and lung in a short-term vitamin B-6 deficiency experiment by Sampson \& O'Connor [29]. This difference in susceptibility to lower vitamin B-6 intake between PLP and PMP may be explained by compartmentalization within cells: intracellular vitamin B-6 has been described as being divided into a slow (mostly mitochondrial PMP) and a fast (mostly cytosolic PLP) pool $[30,31]$. In our experiment only the liver PMP/PLP concentration ratio values are in line with the short-term feeding studies mentioned, whereas in gastrocnemius muscle, heart, brain and kidney PMP level is not preserved to a larger extent than tissue PLP level. The difference between our observations and results from earlier studies probably can be explained by the duration of the study. After a 12-month feeding period even intracellular vitamin B-6 compartments that equilibrate extremely slowly most likely reached a steady state at the lower dietary vitamin B-6 intake level.

When comparing PLP and PMP levels in various body compartments of the $<0.5 \mathrm{mg} / \mathrm{kg}$ diet rats on the one hand and of animals fed the 3 and $6 \mathrm{mg} / \mathrm{kg}$ diets on the other, plasma (PLP) levels were affected more by lower vitamin B-6 intake than tissue (PLP and PMP) levels. Plasma PLP levels in the $<0.5 \mathrm{mg} / \mathrm{kg}$ rats were approximately $10 \%$ of control values (Table 3 ) whereas tissue PLP or PMP levels were $40-80 \%$ of control levels (Fig. 2). These observations are consistent with results of earlier short-term vitamin B-6 deficiency studies on rats [29, 32]. Brain PLP as well as PMP level were least affected by low dietary vitamin B-6 intake; B-6 vitamer 
concentrations in brain tissue of the $<0.5 \mathrm{mg} / \mathrm{kg}$ rats were only $20-30 \%$ lower than those in brain tissue of control animals. Apparently, some protective mechanism sequesters vitamin B-6 in brain tissue and, to a lesser extent, in heart tissue. This finding is consistent with results of one of the short-term deficiency studies [32].

Table 4. Vitamin B-6 metabolizing enzyme activities.

\begin{tabular}{|c|c|c|c|c|c|c|c|c|}
\hline \multirow[t]{2}{*}{ Parameter } & \multirow[t]{2}{*}{ Sex } & \multicolumn{3}{|c|}{ Diet ( $\mathrm{mg} / \mathrm{kg} \mathrm{PN} \cdot \mathrm{HCl})$} & \multirow[t]{2}{*}{$\mathrm{SED}^{\mathbb{2}}$} & \multicolumn{3}{|c|}{ Significance? } \\
\hline & & $<0.5$ & 3 & 6 & & diet & sex & diet $\times \operatorname{sex}$ \\
\hline \multicolumn{9}{|c|}{ PL.kinase (nmol/h per mg protein) } \\
\hline \multirow{2}{*}{ Liver $(\mathrm{pH} T)$} & $\mathrm{M}$ & 4.2 & 5.2 & 6.0 & 1.2 & NS 1 & $<0.001$ & NS \\
\hline & $\mathrm{F}$ & 7.1 & 9.2 & 8.6 & & & & \\
\hline \multirow{2}{*}{$\begin{array}{l}\text { Gastrocnemius } \\
\text { musche (pH 9) }\end{array}$} & $M$ & 0.68 & 0.53 & 0.79 & 0.10 & NS & NS & NS \\
\hline & $\mathrm{F}$ & 0.70 & 0.73 & 0.77 & & & & \\
\hline \multirow{2}{*}{ Heart $(\mathrm{pH} 9)$} & $\mathrm{M}$ & 1.22 & 1.17 & 1.09 & 0.16 & NS & 0.009 & NS \\
\hline & $\mathrm{F}$ & 1.45 & 1.38 & 1.42 & & & & \\
\hline \multirow[t]{2}{*}{ Brain $(p H 7)$} & $\mathrm{M}$ & 22.8 & 21.7 & 21.6 & 0.9 & 0.023 & NS & NS \\
\hline & $\mathrm{F}$ & 23.2 & 21.3 & 20.8 & & & & \\
\hline \multirow[t]{2}{*}{ Kidney $(\mathrm{pH} 7)$} & M & 19.5 & 20.8 & 19.9 & 1.4 & NS & NS & NS \\
\hline & $\mathrm{F}$ & 19.6 & 21.0 & 18.3 & & & & \\
\hline \multirow{2}{*}{$\begin{array}{l}\text { Erythrocytes } \\
(\mathrm{pH} 7)\end{array}$} & M & 5.14 & 3.35 & 3.26 & 0.83 & NS & NS & NS \\
\hline & $F$ & 4.46 & 4.27 & 3.55 & & & & \\
\hline \multicolumn{9}{|c|}{ PLP-hydrolase (nnolih per mg prosein) } \\
\hline \multirow{2}{*}{ Liver } & $\mathrm{M}$ & 2.68 & 2.16 & 2,44 & 0.26 & $<0.001$ & NS & NS \\
\hline & $\mathrm{F}$ & 2.84 & 1.82 & 1.92 & & & & \\
\hline \multirow{2}{*}{$\begin{array}{l}\text { Gastrocnemius } \\
\text { muscle }\end{array}$} & $M$ & 1.48 & 11.23 & 1.50 & 0.24 & NS & 0.005 & NS \\
\hline & $\mathrm{F}$ & 1.90 & 1.75 & 1.80 & & & & \\
\hline \multirow[t]{2}{*}{ Heart } & $\mathrm{M}$ & 6.89 & 6.49 & 6.60 & 0.56 & NS & NS & NS \\
\hline & $\mathrm{F}$ & 7.15 & 6.97 & 6.75 & & & & \\
\hline \multirow[t]{2}{*}{ Brain } & $\mathrm{M}$ & 44.6 & 44.7 & 42.4 & 3.2 & NS & NS & NS \\
\hline & $F$ & 43.6 & 42.6 & 37.3 & & & & \\
\hline \multirow[t]{2}{*}{ Kidney } & $\mathrm{M}$ & 690 & 450 & 500 & 130 & NS & $<0.001$ & NS \\
\hline & F & 850 & 800 & 870 & & & & \\
\hline \multicolumn{9}{|c|}{ PL.oxidase (wntholh per mg protein } \\
\hline \multirow[t]{2}{*}{ Liver (pH T) } & $\mathrm{M}$ & 31.9 & 50.2 & 53.8 & 4.0 & $<0.001$ & $<0.001$ & 0.006 \\
\hline & $F$ & 26.4 & 34.4 & 28.1 & & & & \\
\hline \multicolumn{9}{|c|}{ PL. dehydrogenase (nmol/h per mg protein) } \\
\hline \multirow[t]{2}{*}{ Liver $(p H 4)$} & $\mathrm{M}$ & 22.3 & 32.5 & 32.3 & 2.6 & $<0.001$ & $<0.001$ & NS \\
\hline & $F$ & 20.0 & 23.6 & 19.6 & & & & \\
\hline
\end{tabular}

' $M$, male: F, female: SED, standard error of the difference; NS not significant.

2 ANOVA using factors diet ( $<0,5,3$ and $6 \mathrm{mg} \mathrm{PN} \cdot \mathrm{HCl}$ per $\mathrm{kg}$ diet) and sex $(\mathrm{M}, \mathrm{F})$.

*Activities in $\mu \mathrm{mol} / \mathrm{h}$ per mmol hemoglobin. 
Activities of vitamin B-6 metabolizing enzymes are listed in Table 4 . When comparing PL-kinase activity in various organ tissues, brain showed highest activity, closely followed by kidney. Liver activity was intermediate, while muscle and heart showed low activity. PL-kinase activity was measured in erythrocytes, too.

Comparison to tissue activities is not possible because activity in red blood cells is expressed per mmol hemoglobin, not per $\mathrm{mg}$ protein. PLP-hydrolase activity was distributed differently from PL-kinase activity. Kidney tissue showed a very high PLP-hydrolase activity compared to all other tissues. Brain tissue activity was next highest, followed by heart, liver and gastrocnemius muscle. Plasma alkaline phsophatase (AP; identical with PLP-hydrolase, see [13]) activity is shown in Table 2.

Significant diet-related differences in vitamin B-6 metabolizing enzyme activities between the $<0.5 \mathrm{mg} / \mathrm{kg}$ and the $6 \mathrm{mg} / \mathrm{kg}$ diet groups were observed onlly for liver PLP-hydrolase, PL-oxidase and PL-dehydrogenase, for brain PL-kinase and for plasma AP. Liver PLP-hydrolase, brain PL-kinase and plasma AP activities were higher in the $<0.5 \mathrm{mg} / \mathrm{kg}$ diet group than in control rats, but PL-oxidase and PL-dehydrogenase activities were lower. No significant differences were observed between the 3 and $6 \mathrm{mg} / \mathrm{kg}$ diet groups. Meisler et al. observed a differential response of PL-kinase activity in liver and brain of young male rats fed a vitamin B-6 deficient diet for 5 weeks [33]. Compared to control values, PL-kinase activity in liver tissue of deficient rats was $50 \%$ lower but in brain tissue only $14 \%$ lower.

PLP-hydrolase and PMP-oxidase activities were not significantly influenced in any organ examined. In our study the enzymes showing a response to low dietary vitamin B-6 intake were not identical, but our animals were older and had been on the experimental diets for a much longer period of time. In accordance with the findings of Meisler et al., the observed significant differences in vitamin B-6 metabolizing enzyme activities between the $<0.5 \mathrm{mg} / \mathrm{kg}$ diet and the $6 \mathrm{mg} / \mathrm{kg}$ diet suggest a shift towards protection of brain vitamin B-6 content relative to that of liver and plasma (Tables 2 and 4). The lower PL-oxidase and PL-dehydrogenase activities in liver of the $<0.5 \mathrm{mg} / \mathrm{kg}$ rats compared to controls suggest a shift towards lower vitamin B-6 catabolism with lower vitamin B-6 intake.

Significant differences between sexes were observed for liver and heart PL-kinase and for gastrocnemius muscle and kidney PLP-hydrolase, with female rats showing higher activities than males, and for liver PMP-oxidase, PL-oxidase and PL-dehydrogenase, with females showing lower activities than male rats fed the same diet (Table 4). However, significant sex-related differences in PLP or PMP tissue concentrations were not observed. On the other hand, the lower urinary 4-PA excretion (as a percentage of vitamin B-6 intake, see Table 3 ) observed in female rats corresponded well with the lower liver PL-oxidase and PL-dehydrogenase activities measured. 
PL-oxidase and PL-dehydrogenase on the one hand and PL-kinase on the other compete for the same substrate PL. Under physiological conditions PL-degradative activity (mostly PL-oxidase) is larger than PL-kinase activity [14]. When comparing male and female rats on the same diet, liver PL-oxidase activity was higher in males, while male liver PL-kinase activity was lower (Table 4). Male rats, however, did not show lower liver PLP concentrations than corresponding females. This is suggested to be explained by the regulatory role of protein binding in controlling intracellular PLP levels [14]. The effect of low dietary vitamin B-6 intake on tissue protein binding of PLP was studied in gastrocnemius muscle samples. In striated muscle tissue GP is the major PLP-binding protein; approximately $90 \%$ of all PLP present in rat muscle has been calculated to be bound to GP $[30,34]$.

Regulation of muscle GP and of muscle PLP-binding capacity has not yet been completely elucidated. At high (adequate or excess) intake levels of vitamin B-6, muscle GP activity and total muscle vitamin B-6 increased steadily and in an almost constant ratio in young rats [34]. When these rats were switched to a vitamin B-6 deficient diet, they retained the GP activity accumulated during high vitamin B-6 intake. When vitamin B-6 deficiency was prolonged, GP activity ultimately decreased, but only after weight loss had occurred. In experiments by the same investigators it was found that (partial) starvation causes a prompt depletion of muscle GP [35]. GP turnover was observed to be dependent on physical activity in mouse skeletal muscle. Under muscle-wasting conditions, i.e. dystrophy or denervation, GP degradation rate was higher than in control muscle [36]. GP has a key function in muscle glycogenolysis and overall glucose homeostasis. It was therefore concluded by Black et al. that the degradation of muscle GP is more sensitive to caloric restriction than to inadequate vitamin B-6 supply [35]. Possibly protein degradation, for example induced by starvation, is an important factor in controlling muscle PLP content.

Our experimental animals fed the $<0.5 \mathrm{mg} / \mathrm{kg}$ diet showed signficantly lower GP activity than control rats (Table 5). Addition of excess PLP to the assay mixture did not result in an increase in activity in any sample. It is concluded that no apo-GP was present in any muscle sample, including those from rats fed the $<0.5 \mathrm{mg} / \mathrm{kg}$ diet. This finding is in line with the observed high affinity of GP to its cofactor PLP [37]. Furthermore, it is concluded that the lower total GP activity in cleficient animals was caused by the lower enzyme mass present. At least two explanations for lower GP mass are possible. First, less GP enzyme could have accumulated during the rapid growth phase due to vitamin B-6 deprivation. Second, GP turnover could have increased, induced by caloric restriction.

Percent of total PLP present in muscle tissue bound to GP was calculated as described by Black et al. [34]. Percent of GP-bound PLP showed a large interindividual variation but did not differ significantly between diet groups. Overall average muscle PLP bound to GP was $76 \%$, which is somewhat lower than the values observed earlier $[30,34]$. It is concluded that in our experimental animals 
Table 5. Gastrocnemius muscle GP activity.

\begin{tabular}{|c|c|c|c|c|c|c|c|c|}
\hline \multirow[t]{2}{*}{ Parmeter } & \multirow[t]{2}{*}{ Sex? } & \multicolumn{3}{|c|}{ Diet (mg/kg $\mathrm{PN} \cdot \mathrm{HCl})$} & \multirow[t]{2}{*}{ SED } & \multicolumn{3}{|c|}{ Significence? } \\
\hline & & $<0.5$ & 3 & 6 & & diet & $\operatorname{sex}$ & diet $\times s$ s \\
\hline $\begin{array}{l}\text { Total GP } \\
\text { (pmol/min perg) }\end{array}$ & $\begin{array}{l}\mathrm{M} \\
\mathrm{F}\end{array}$ & 2.4 & $\begin{array}{l}7.3 \\
4.7\end{array}$ & $\begin{array}{l}7.3 \\
9.3\end{array}$ & $\begin{array}{l}1.0 \\
7.7\end{array}$ & $<0.001$ & 0016 & NS \\
\hline $\begin{array}{l}\text { GP-AC ( + PLP/-PLP } \\
\text { activity ratio) }\end{array}$ & $\begin{array}{l}\mathrm{M} \\
\mathrm{F}\end{array}$ & $\begin{array}{l}1.038 \\
1.011\end{array}$ & $\begin{array}{l}1.004 \\
0.995\end{array}$ & $\begin{array}{l}0.986 \\
1.004\end{array}$ & 0.026 & NS & NS & NS \\
\hline $\begin{array}{l}\text { PLP bound to GP } \\
\text { (\% of muscle PLP) }\end{array}$ & $\begin{array}{l}\mathrm{M} 5 \\
\mathrm{~F}\end{array}$ & 54 & $\begin{array}{l}74 \\
88\end{array}$ & $\begin{array}{l}72 \\
91\end{array}$ & $\begin{array}{l}13 \\
77\end{array}$ & NS & 0.027 & NS \\
\hline
\end{tabular}

IM, male; F, female; SED, standard error of the difference; $N S_{*}$, not significant.

2. ANOVA using factors diet $(<0,5,3$ and $6 \mathrm{mg} \mathrm{PN}$. HCl per $\mathrm{kg}$ diet) and $\operatorname{sex}(\mathrm{M}, \mathrm{F})$.

${ }^{3}$ Measured after prencubation with AMP.

gastrocnemius muscle PLP level was most likely regulated by PLP-binding capacity of GP enzyme mass present. Possibly tissue vitamin B-6 content in general is regulated by (PLP) binding capacity. To improve the vitamin B-6 status on the organ level not only higher organ vitamin B-6 uptake would have to be assured (by increasing dietary vitamin B-6 intake), but possibly also organ tissue (and total body) protein balance. More research into the relation between vitamin B-6 (deficiency) and protein turnover is warranted.

\section{Vitamin B-6 dependent enzymes}

More functional parameters of vitamin B-6 status are the activities of vitamin B-6 dependent enzymes. The vitamin B-6 dependent enzymes studied in our experimental rats were chosen to cover a wide range of characteristics. ALAT and ASAT show a high cofactor PLP affinity compared to TAT and SDH; the half-life of ALAT and ASAT is long compared to that of TAT and SDH; ALAT, SDH and TAT are (predominantly) cytosolic enzymes whereas ASAT is predominantly located in mitochondria [38-42]. Besides liver homogenate activities (Fig. 3), data on erythrocyte ASAT (Table 3) and plasma ALAT and ASAT activities (Table 2) were obtained.

Enzyme activities measured without excess PLP added to the reaction mixture (-PLP) are supposed to represent holoenzyme activity present in the sample. With excess PLP added ( + PLP), and after preincubation to allow for cofactor binding to any apoenzyme present, total enzyme activities, i.e. holo- plus apoenzyme activities added, are supposed to be measured. AC values close to unity indicate that holoenzyme is the more abundant enzyme form, whereas $\mathrm{AC}$ values $>2$ indicate that more apoenzyme than holoenzyme is present.

When comparing the data on both high-cofactor-affinity enzymes, ALAT and ASAT, in liver a different effect of low vitamin B-6 intake is noted (Fig. 3). Both enzymes showed lower holoenzyme activity in the $<0.5 \mathrm{mg} / \mathrm{kg}$ diet group liver than 


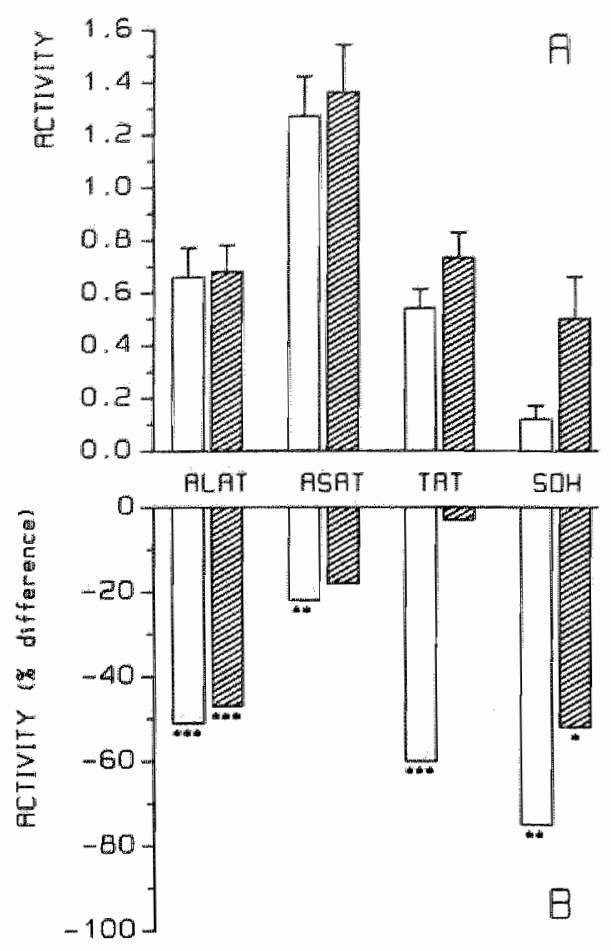

Fig. 3. Liver issue activities of alanine aminotransferase (ALAT, U/mg protein), aspartate aminotransferase (ASAT, U/mg protein), tyrosine aminotransferase (TAT, umol/h per mg protein) and serine dehydratase (SDH, $\mu$ mol/h per mg protein). Open bars, without PLP added; shaded bars, with PLP added. A, mean liver tissue activities of warious enzymes (and SED) in male and female control rats $(n=12), \mathbb{B}$, difference $(\%)$ in liver tissue activities between diet groups $<0.5 \mathrm{mg} / \mathrm{kg}$ and $6 \mathrm{mg} / \mathrm{kg}$ (control). Significance of difference between diet groups: $P<0.05$, ** $P<0.01$, $* * P<0.001$.

in control rat liver, albeit ALAT holoenzyme activity to a larger extent than ASAT holoenzyme activity. ALAT showed a significantly lower total liver enzyme activity in the $<0.5 \mathrm{mg} / \mathrm{kg}$ diet group than in the $6 \mathrm{mg} / \mathrm{kg}$ diet group, whereas ASAT total liver enzyme activity did not differ significantly between diet groups. This seems to be in line with the cellular distribution of ALAT and ASAT in the liver. The predominantly mitochondrially located ASAT holoenzyme (and apoenzyme) is conserved better under conditions of low vitamin B-6 intake than the predominantly cytosolically located ALAT.

The influence of low vitamin B-6 intake on ASAT activity differed between erythrocytes and liver (Table 3 and Fig. 3, respectively). In erythrocytes, both holoenzyme and total enzyme activities were significantly lower in rats fed the $<0.5 \mathrm{mg} / \mathrm{kg}$ diet than in controls. In liver samples from the same rats holoenzyme 
activities, but not total enzyme activities, were significantly influenced by dietary vitamin B-6 intake. In animals fed the 3 and $6 \mathrm{mg} / \mathrm{kg}$ diets both liver and erythrocyte ASAT were predominantly present in the holoenzyme form (average ASAT-AC value 1.06). The average liver ASAT-AC value of 1.20 in rats fed the $<0.5 \mathrm{mg} / \mathrm{kg}$ diet indicated that little apoenzyme ASAT was present in the liver of these animals. However, in erythrocytes of rats fed the $<0.5 \mathrm{mg} / \mathrm{kg}$ diet apoenzyme ASAT was the predominant enzyme form. Erythrocyte ASAT seemed to be more susceptible to tow vitamin B-6 intake than liver ASAT. This is probably related to a difference in intracellular location as well. In liver ASAT activity is predominantly located within mitochondria, whereas in erythrocytes, which lack intracellular organelles, all ASAT activity is cytosolic.

In liver the low PLP affinity enzyme TAT was influenced by dietary vitamin B-6 intake in the same way as the high PLP affinity enzyme ASAT (Fig. 3). For both liver enzymes total enzyme activity was not influenced by diet, whereas holoenzyme activity was significantly lower in rats fed the $<0.5 \mathrm{mg} / \mathrm{kg}$ diet than in control rats. As a result, both ASAT-AC and TAT-AC were higher in the $<0.5 \mathrm{mg} / \mathrm{kg}$ group. Compared to holoenzyme ASAT activity, however, holoenzyme TAT activity was lowered to a larger extent by a low dietary vitamin B-6 intake. Moreover, even in the $<0.5 \mathrm{mg} / \mathrm{kg}$ animals holoenzyme ASAT was the predominant liver enzyme form, whereas liver TAT was predominantly present in the apoenzyme form in all animals including controls.

The low PLP affinity enzyme SDH reacted to low dietary vitamin B-6 intake in a comparable way as the high-affinity enzyme ALAT. For SDH and ALAT both holoenzyme and total enzyme activities were lower in the $<0.5 \mathrm{mg} / \mathrm{kg}$ livers than in those of controls. This differencewas stronger for (total) SDH activity than for ALAT activity. Moreover, liver ALAT was predominantly present in the holoenzyme form (ALAT-AC averaged 1.04 for the $6 \mathrm{mg} / \mathrm{kg}$ diet and 1.30 for the $<0.5 \mathrm{mg} / \mathrm{kg}$ diet), whereas most liver SDH present was in the apoenzyme form, even in control rats (SDH-AC averaged 4.5 in the $6 \mathrm{mg} / \mathrm{kg}$ rats and $>5$ in the $<0.5 \mathrm{mg} / \mathrm{kg}$ animals).

Generally, the effect of low dietary vitamin B-6 intake was larger on the low PLP affinity liver enzymes SDH and TAT than on the high PLP affinily liver enzymes ALAT and ASAT. It has been suggested that PLP coenzyme transfer from low to high PLP affinity enzymes might explain the observed differences in diet-related effects [32]. Furthermore, the intracellular location of the enzyme involved seems to be explanatory. Parameters of the predominantly mitochondrial liver ASAT were influenced less by low vitamin B-6 intake than parameters of the (predominantly) cytosolic liver ALAT, TAT and SDH and erythrocyte ASAT.

Plasma ALAT and ASAT activities are generally accepted clinico-biochemical parameters of heart and liver function. In clinico-biochemical evaluation total plasma activities are measured, i.e. activities with PLP added. Table 2 illustrates that in rats both plasma ALAT and ASAT activities are significantly influenced by low vitamin B-6 intake. This diet-related decrease in plasma aminotransferase activities might influence interpretation of clinico-biochemical data in terms of organ function. 
Table 6. Hematology (blood sample obtamed by tail puncture).

\begin{tabular}{|c|c|c|c|c|c|c|c|c|}
\hline \multirow[t]{2}{*}{ Parameter } & \multirow[t]{2}{*}{$5 e x^{3}$} & \multicolumn{3}{|c|}{ Diel $(\mathrm{mg} / \mathrm{kg} \mathrm{PN} \cdot \mathrm{HCl})$} & \multirow[t]{2}{*}{$S E D$} & \multicolumn{3}{|c|}{ Significance? } \\
\hline & & $<0.5$ & 3 & 6 & & diet & $\operatorname{sex}$ & diet $\times s e x$ \\
\hline \multirow{2}{*}{$\begin{array}{l}\text { Hemoglobin } \\
\text { (mmoll) }\end{array}$} & $M$ & 8.2 & 9.5 & 9.5 & 0.2 & $<0.001$ & $\mathrm{NS}^{1}$ & NS \\
\hline & $\mathbb{F}$ & 8.6 & 9.4 & 9.4 & & & & \\
\hline \multirow{2}{*}{$\begin{array}{l}\text { Hematocrit } \\
(1 / /)\end{array}$} & $\mathrm{M}$ & 0.443 & 0.491 & 0.483 & 0.010 & 0.001 & 0.019 & 0.01. \\
\hline & $F$ & 0.452 & 0.455 & 0.465 & & & & \\
\hline \multirow{2}{*}{$\begin{array}{l}\text { Eryhrocytes } \\
(10,12)\end{array}$} & $\mathrm{M}$ & 8.5 & 7.6 & 7.7 & 0.2 & $<0.001$ & $<0.001$ & NS \\
\hline & $\mathbb{F}$ & 7.9 & 6.9 & 7.0 & & & & \\
\hline \multirow{2}{*}{$\begin{array}{l}\mathrm{MCV} \\
\text { (II) }\end{array}$} & $M$ & 53 & 65 & 63 & 2 & $<0.001$ & 0.019 & NS \\
\hline & $\mathrm{F}$ & 57 & 66 & 67 & & & & \\
\hline \multirow{2}{*}{$\begin{array}{l}\mathrm{MCH} \\
\text { (frmol) }\end{array}$} & $M$ & 0.98 & 1.26 & 1.24 & 0.04 & $<0.001$ & $<0.001$ & NS \\
\hline & $F$ & 1.08 & 1.36 & 1.35 & & & & \\
\hline \multirow{2}{*}{$\begin{array}{l}\mathrm{MCHC} \\
(\mathrm{m} m \mathrm{~mol} / \mathrm{l})\end{array}$} & $M$ & 18.6 & 19.4 & 19.6 & 0.3 & $<0.001$ & $<0.001$ & NS \\
\hline & $F$ & 18.9 & 20.6 & 20.3 & & & & \\
\hline \multirow{2}{*}{$\begin{array}{l}\text { Reticulocytes } \\
(\%)\end{array}$} & $\mathrm{M}$ & 0.63 & 0.33 & 0.53 & 0.22 & NS & NS & NS \\
\hline & $F$ & 0.67 & 0.37 & 0.27 & & & & \\
\hline \multirow{2}{*}{$\begin{array}{l}\text { Thrombocytes } \\
\left(10^{12 / 1)}\right.\end{array}$} & $\mathrm{M}$ & 1.397 & 1.118 & 1.126 & 0.066 & $<0.001$ & $<0.001$ & NS \\
\hline & $F$ & 1.184 & 0.924 & 1.085 & & & & \\
\hline \multirow{2}{*}{$\begin{array}{l}\text { Prothrombin time } \\
\text { (s) }\end{array}$} & $\mathrm{M}$ & 36.5 & 37.5 & 36.5 & 1.4 & NS & $<0.00 \|$ & NS \\
\hline & $F$ & 34.8 & 33.2 & 33.8 & & & & \\
\hline
\end{tabular}

' $M$, male; F, female; SED, standard error of the difference; NS, not significant.

${ }^{2}$ ANOVA using factors diet ( $<0.5,3$ and $6 \mathrm{mg} \mathrm{PN} \cdot \mathrm{HCl}$ per $\mathrm{kg}$ diet) and sex (M. F).

\section{Hematology}

All red blood cell parameters evaluated suggested the presence of hypochromic microcytic anemia in the animals fed the $<0.5 \mathrm{mg} / \mathrm{kg}$ diet (Table 6). Vitamin B-6 is involved in red blood cell formation via the PLP-dependent enzyme o-aminolevulinate synthase. This enzyme catalyzes the condensation of glycine with succinylCoA to form 8 -aminolevulinic acid, an important intermediate of porphyrin biosynthesis. The lower plasma bilirubin level observed in the $<0.5 \mathrm{mg} / \mathrm{kg}$ rats compared to controls (Table 2 ) is probably not related to changes in liver function but is more likely attributable to diet-related differences in red blood cell parameters.

PLP inhibits the coagulation of blood, probably via protein modification (formation of Schiff base) [43]. Although the thrombocyte count was significantly higher in the $<0.5 \mathrm{mg} / \mathrm{kg}$ rats than in controls, prothrombin time was not influenced by dietary vitamin B-6 level (Table 6).

\section{White blood cell characteristics}

Male rats fed the $<0.5 \mathrm{mg} / \mathrm{kg}$ diet showed a significantly lower lymphocyte count, and a concomitantly higher neutrophil count, than corresponding control rats. (Table 7). A decreased lymphocyte count is a characteristic functional response to isolated vitamin B-6 deficiency in rats, but the influence of vitamin B-6 deprivation 
Table 7. Differential white blood cell counts (blood sample obtained by tail puncture)

\begin{tabular}{|c|c|c|c|c|c|c|c|c|}
\hline \multirow[t]{2}{*}{ Parameter } & \multirow[t]{2}{*}{$\operatorname{Sex} x^{\prime}$} & \multicolumn{3}{|c|}{ Diet (mg/kg PN/HCl) } & \multirow[t]{2}{*}{$\mathrm{SED}^{\mathrm{i}}$} & \multicolumn{3}{|c|}{ Significa roe } \\
\hline & & $<0.5$ & 3 & 6 & & dist & $\operatorname{sex}$ & dietrsex \\
\hline \multirow{2}{*}{$\begin{array}{c}\text { Leukgcytes } \\
\left(10^{9} n\right)\end{array}$} & $\mathrm{M}$ & 11.7 & 12.5 & 13.2 & \multirow[t]{2}{*}{0.8} & \multirow[t]{2}{*}{ NS } & \multirow[t]{2}{*}{$<0.001$} & \multirow[t]{2}{*}{ NS } \\
\hline & $F$ & 6.5 & 5.9 & 7.2 & & & & \\
\hline \multirow{2}{*}{$\begin{array}{l}\text { Lymphocytes } \\
(\%)\end{array}$} & M & 57.3 & 79.7 & 74.2 & \multirow[t]{2}{*}{4.8} & \multirow[t]{2}{*}{$<0.001$} & \multirow[t]{2}{*}{ NS ${ }^{\prime}$} & \multirow[t]{2}{*}{ NS } \\
\hline & $F$ & 71.3 & 82.8 & 72.8 & & & & \\
\hline \multirow{2}{*}{$\begin{array}{l}\text { Lymphocytes } \\
\left(10^{9} / 1\right)\end{array}$} & $M$ & 6.6 & 10.0 & 9.7 & \multirow[t]{2}{*}{0.6} & \multirow[t]{2}{*}{$<0.001$} & \multirow[t]{2}{*}{$<0.001$} & \multirow[t]{2}{*}{0.004} \\
\hline & $\mathbb{F}$ & 4.7 & 4.9 & 5.3 & & & & \\
\hline \multirow{2}{*}{$\begin{array}{l}\text { Neutrophils } \\
(\%)\end{array}$} & $\mathrm{M}$ & 39.3 & 18.0 & 24.0 & \multirow[t]{2}{*}{5.1} & \multirow[t]{2}{*}{0.001} & \multirow[t]{2}{*}{0.037} & \multirow[t]{2}{*}{ NS } \\
\hline & $F$ & 23.3 & 15.3 & 23.5 & & & & \\
\hline \multirow{2}{*}{$\begin{array}{l}\text { Neutrophils } \\
\left(10^{9} /\right)\end{array}$} & $\mathrm{M}$ & 4.7 & 2.3 & 3.2 & \multirow[t]{2}{*}{0.7} & \multirow[t]{2}{*}{0.011} & \multirow[t]{2}{*}{$<0.001$} & \multirow[t]{2}{*}{$\mathrm{NS}$} \\
\hline & $F$ & 1.5 & 0.9 & 1.7 & & & & \\
\hline \multirow{2}{*}{$\begin{array}{l}\text { Monocytes } \\
(\%)\end{array}$} & M & 0.7 & 0.7 & 0.5 & \multirow[t]{2}{*}{0.4} & \multirow[t]{2}{*}{ NS } & \multirow[t]{2}{*}{ NS } & \multirow[t]{2}{*}{ NS } \\
\hline & $F$ & 1.3 & 0.5 & 0.8 & & & & \\
\hline \multirow{2}{*}{$\begin{array}{l}\text { Eosinophils } \\
(\%)\end{array}$} & $\mathrm{M}$ & 2.7 & 1.7 & 1.3 & 0.9 & NS & NS & NS \\
\hline & $F$ & 3.2 & 1.3 & 2.5 & & & & \\
\hline Basophills & M & 0 & 0 & 0 & 0.3 & NS & NS & NS \\
\hline$(\%)$ & $\mathbb{F}$ & 0.8 & 0 & 0.3 & & & & \\
\hline
\end{tabular}

${ }^{1} \mathrm{M}$, male; $\mathrm{F}$, female; SED, standard error of the difference; NS, not significant.

2. ANOVA using factors diet $(<0.5,3$ and $6 \mathrm{mg}$ PN. HCl per $\mathrm{kg}$ diet) and sex $(M, F)$.

Table 8. Thymic involution.

\begin{tabular}{|c|c|c|c|c|c|c|c|c|}
\hline \multirow[t]{2}{*}{ Parameter } & \multirow[t]{2}{*}{ Sex 1} & \multicolumn{3}{|c|}{ Diet (mg/kg PN-HCl) } & \multirow[t]{2}{*}{$\mathrm{SED}^{\prime}$} & \multicolumn{3}{|c|}{ Significance 2} \\
\hline & & $<0.5$ & 3 & 6 & & diet & $\operatorname{sex}$ & dict $x \operatorname{sex}$ \\
\hline \multirow[t]{2}{*}{ Thymus weight (mg) } & $\mathrm{M}$ & 161 & 224 & 197 & \multirow[t]{2}{*}{43} & \multirow[t]{2}{*}{ NS ${ }^{1}$} & \multirow[t]{2}{*}{$\mathbb{N S}$} & \multirow[t]{2}{*}{ NS } \\
\hline & $\mathbb{F}$ & 116 & 168 & 170 & & & & \\
\hline \multicolumn{9}{|l|}{ Involution scores } \\
\hline \multirow[t]{2}{*}{ Normal thymus } & M & $0 / 6$ & $5 / 6$ & $4 / 5$ & & & & \\
\hline & $\mathrm{F}$ & $1 / 6$ & $5 / 6$ & $5 / 6$ & & & & \\
\hline \multirow[t]{2}{*}{ Slight involution } & $\mathrm{M}$ & $1 / 6$ & $1 / 6$ & $1 / 5$ & & & & \\
\hline & $\mathrm{F}$ & $3 / 6$ & $1 / 6$ & $1 / 6$ & & & & \\
\hline \multirow{2}{*}{$\begin{array}{l}\text { Moderate/marked } \\
\text { involution }\end{array}$} & M & $5 / 6$ & $0 / 6$ & $0 / 5$ & & & & \\
\hline & $\mathrm{F}$ & $2 / 6$ & $0 / 6$ & $0 / 6$ & & & & \\
\hline
\end{tabular}

$1 \mathrm{M}$, male; F, female: SED, standard ertor of the difference; NS, not significant.

2 ANOVA using factors diet $(<0,5,3$ and $6 \mathrm{mg}$ PN. HCl per $\mathrm{kg}$ diel) and sex (M, F).

on white blood cell differential count is usually studied in rats not only fed a vitamin B-6 deficient diet but also treated with the vitamin B-6 antimetabolite DOP. In our 12 -month feeding experiment, in which no DOP was administered, female rats did not show the expected diet-related difference in lymphocyte count.

In accordance with the findings for white blood cell differential count, low vitamin B-6 intake was associated with involution of the thymus. Average thymic weights 
were lower in the $<0.5 \mathrm{mg} / \mathrm{kg}$ diet rats than in the animals fed the $3 \mathrm{mg} / \mathrm{kg}$ or the $6 \mathrm{mg} / \mathrm{kg}$ diets (Table 8); due to the large interindividual variation this difference did not reach statistical significance. Thymic involution scores suggest that female rats were affected less by a low vitamin B-6 intake than male rats. The thymic involution observed was characterized by a decreased cortex-to-medulla ratio due to lymphocyte depletion in the cortex. With marked involution the lymphocyte population pattern was reversed, with a higher density of lymphocytes in the medulla than in the cortex. In some animals hardly any lymphocytes were present in the thymus. These histological changes resembled the end-stage involution induced in rats by treatment with corticosteroids or organotin compounds. Although the animals fed the $<0.5 \mathrm{mg} / \mathrm{kg}$ diet clearly showed a larger extent of thymic involution than animals fed the $3 \mathrm{mg} / \mathrm{kg}$ or the $6 \mathrm{mg} / \mathrm{kg}$ diet, the thymus of some of these $<0.5 \mathrm{mg} / \mathrm{kg}$ animals appeared only slightly affected if at all.

\section{References}

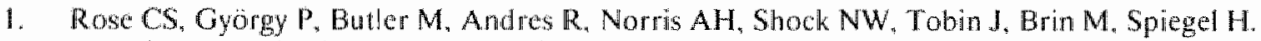
Age differences in vitamin B-status of 617 men. Am J Clin Nutr 1976:29:847-53.

2. Löwik MRH. wan den Berg H, Westenbrink S, Wedel M, Schrujwer J, Ockhuizen Th. Doseresponse relationships regarding vitam in $B-6$ in elderly people: a nationwide nutritional survey (Dutch Nuritional Surveillance System). Am J Clin Nutr 1989:50:391-9.

3. Bode W, Mocking JAJ, van den Berg $\mathrm{H}$. Influence of age and sex on vitamin B-6 vitamer distribution and on vitumin B-6 metabolizing enzymes in Wistar rats. J Nutr $1991: 121 ; 318-29$.

4. Suter PM. Russell RM. Vitamin requirements of the elderly. Am J Clin Nutr 1987;45: 501-12.

5. Hamfall A, Söderhjelm L. Vitamin B-6 and aging. In: Leklem JE, Reynolds RD, Eds. Clinical and physiological applications of vitamin B-6. New York: Alan R. Liss, 1988: 95-107. (Current topics in nutrition and disease Vol. 19.)

6. Kant AK. Moser-Veillon PB, Reynolds RD. Effect of age on changes in plasma, erythrocyte, and urinary B-6 vilamers atter an oral vitamin B-6 load. Am J Clin Nutr 1988;48: 1284-90.

7. Lee CM. Leklem JE. Differences in vitamin B-6 status indicator responses between young and middle-aged wommen fed constant diets with two lexels of vitamin B-6. Am J Clin Nutr 1985;42: $226-34$.

8. Kirsch A. Bidlack WR. Nutrition and the elderly: vitamin status and efficacy of supplementation. Nutrition 1987:3: 305.14.

9. Bieri JG. Stoewsand GS, Briggs GM. Phillips RW. Woodard JC, Knapka JJ. Report of the American Institute of Nutrition. Ad hoc committee on standards for nutritional studies $I$ Nutr 1977:107: 1340-8.

10. Bode W, wonden Berg H. Pyridoxal-5' phosphate and pyridoxal biokinetics in male Wistar rats fod graded levals of vitamin B-6. I Nutr (accepted).

11. van ten Berg M. Bogatrds JJP. Sinkeldam EJ. Schreurs WHP. Effect of different levels of vitanin B-6 in the diet of rats on the content of pyridoxamine-5'-phosphate and pyridoxal-5'phosphate in the liver. Int J Vit Nut Res 1982:52:407-16.

12. Van clen Berg M. Bogatads IJP. Vitamin B-6 metabolism in the pregnant rat: effect of progesteronc on the ( re) distribution in maternal vitamin B-6 stores. J Nutr 1987:117: 1866-74.

13. Lumeng L. Li T-k. Characterization of the pyridoxal -5 " - phosphate and pyridoxamine-5"phosphate hydrolase acitvity in the liver. Identity with alkaline phosphatase. J Biol Chem $1975 ; 250: 8126-31$.

14. Merrill Ir AH. Henderson JM. Wang E, MCDonald BW, Millikan WJ. Metabolism of vitamin B.6 by human liver. J Nutr 1984:1 14: 1664-74.

15. Cori GT, Ilingworth B. Kaller P.J. Musde phosphorylase. Meth Enzymol 1955:1: 200-5. 
16. Bayoumi RA, Rosalki SB. Evaluation of the methods of coenzyme activation of enthrocyte enzymes for detection of deficiency of vitamins B-1, B-2 and B-6. Chin Chem 1976:22:327-35.

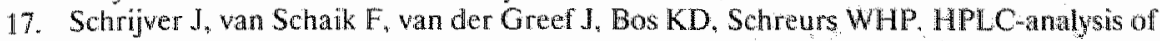
xanthurenic acid and is 8-methyl ether. In: Schlossberger HG. Kochen W. Linzen B. Steinhart H. Eds. Progress in tryptophan and serotonin research. Berlin: Walter de Gruyter, 1984: $71-5$.

18. Krstulovic AM, Matzura C. Rapid analysis of tryptophan metabolites using reversed-phase highperformance liquid chromatography with fluorometric detection. J Chromat 1979:163: 72-6.

19. Diamondstone TI. Assay of tyrosine transaminase activity by conversion of p-hydroxyphenylpyruvate to p-hydroxybenzaldehyde. Anal Biochem 1966:16:395-401.

20. Dakin HD, Dudey HW. The interconversion of $\alpha$-amino-acids, $\alpha$-hydroxy-acids and $\alpha$-ketonic aldehydes. Part II. J Biol Chem 1913:15: 127-43.

21. Coburn SP, Mahuren JD, Schattenbrand WE, Wostnnan BS, Madsen D. Edfects of vitamin B-6 deficiency and $4^{\prime}$-deoxypyridoxine on pyridoxal phosphate concertration, pyridoxine kinase and other aspects of metabolism in the rat. J Nutr 1981:111:391 -8.

22. Lumeng L, Li T-k. Mammalian vitamin B-6 metabolism. regulatory role of protein-binding and the hydrolysis of pyridoxal-5 -phosphate in storage and transport. In: Tryfiates GP. Ed. Vitamin B-6 metabolism and role in growth. Westport: Food \& Nutrition Press, 1980: 27-52.

23. Henderson LM. Vitamin B-6. In: Olson RE, Broquist HP, Chichester CO, Darby WJ, Kolby Jr AC, Stalvey RM, editorial committee. Present Knowledge in Nutrition, 5 th ed. Washington: The Nutrient Foundation, 1984: 303-17.

24. Chandra RK, Au B. Heresi G. Single nutrient deficiency and cell-mediated immune response. II. Pyridoxine. Nutr Res 1981;1: 101-6.

25. Driskell JA, Kirksey A. The cellular approach to the determination of pyridoxine requirement in pregnant and non-pregnant rats. J Nutr 1971;101:661-8.

26. Driskell JA, Strickland LA, Poon CH, Foshnee DP. The witamin B-6 requirement of the male rat as determined by behavioral patterns, brain pyridoxal phosphate and nucleic acid composition and erythrocyte alanine aminotransferase activity. I Nutr 1973;103; 670-80.

27. Driskell JA. Chrisley BM, Pierotti JA, Hefferan TE. High-performance liquid chromatographic analysis of vitamin $B-6$ components in tissues and status assessment. Nutr Rep $\operatorname{In} 1987 ; 35$ : $1247-59$.

28. Bender DA. Oestrogens and vitamin B-6 - actions and interactions. Wld Rev Nutr Dief 1987;51: $140-88$.

29. Sampson DA, O'Connor DK. Response of B-6 vitamers in plasma, erythrocytes and tissues to vitamin B-6 depletion and repletion in the rat. J Nutr 1989;119:1940-8.

30. Bosron WF, Veitch RL, Lumeng L, Li T-k. Subcellular localization and identification of pyridoxal-5'-phosphate-binding proteins in rat liver. J Biol Chem 1978;253: 1488-92.

31. Lui A Lumeng L. Li T-K. Stability of vitamers and location of pyridoxal-P hydirolase activity in isolated rat liwer mitochondria. Fedn Proc 1980;39:558 (abstract).

32. Lumeng $L$, Ryan MP, Li T-K. Validation of the diagnostic vallue of plasma pyridoxal -5 . phosphate measurements in vitamin B-6 nutrition of the rat. J Natr 1978;108:545-53.

33. Meister NT, Thanasci JW. Pyridoxine kinase, pyrtidoxine phosphate phosphatase and pyridoxinc phosphate oxidase acilvites in control and B-6 deficient rall liver and brain. I Nut $1980: \$ 10$ : 1965-75.

34. Black AL, Guirard BM. Snell EE. Increased muscle phosphorylase in rats fed high level of vitamin B-6. J Nutr 1977:107: 1962-8.

35. Black AL, Guirard BM, Snell EE. The behavior of muscle phosphorylase as a reservoir for vitamin B-6 in the rat. J Nutr 1978; 108: 670-7.

36. Beynon RJ, Fairhurst D. Cookson. EJ. Tu nover of skeletal muscle glycogen phosphorylatse. Biomed Biochim Acta 1986;45: 1619-25.

37. Shimomura $\$$. Fukui "l. Characterization of the pyridoxal phosphate site in glycogen phosphorylase b from rabbit muscle. Biochemistry 1978;17:5359-67.

38. Nakagawa H. Kimura H, Miura S. Crystallization and characteristics of serine dehydralase from rat liver. Biochem Biophys Res commun 1967:28: 359-64.

39. Hayashi S-i, Granmer DK, Tomkins GM. Tyrosine aminotransferase: purification and characterization. J Biol Chem 1967;242: 3998-4006. 
40. Schimke RT. Regulation of protein metabolism in mammalian tissues. In: Munro HN, Ed. Mammalian protein metabolism. New York: Academic Press, 1970: 177-228.

41. DeRosa G, Schwick RW. Metabolic implications of the distribution of aspartate amonitransferase isozymes. J Biol Chem 1975:250:7961-7.

42. Bamber ME \& Doonan S. A quantitative study of subcellular distribution of aspartate aminotransferase isorymes in ral liver. Int J Biochem 1976;7:119-24.

43. Anonymous. Inhibition of platelet aggregation and clotting by pyridoxal-5"phosphate. Nutr Rev $1982: 40: 55-7$. 


\section{Pyridoxal-5'-phosphate and pyridoxal biokinetics in male Wistar rats fed graded levels of vitamin B-6}

Wilhelmina Bode and Henk van den Berg

\section{Abstract}

Biokinetic parameters of plasma pyridoxal-5'-phosphate (PLP) and pyridoxal (PL) disposition were studied in male Wistar rats aged 8 months fed a purified diet containing $<0.5$, ca. 3 or ca. $6 \mathrm{mg}$ pyridoxine $\cdot \mathrm{HCl}$ per $\mathrm{kg}$ from weaning, with animals on the $6 \mathrm{mg} / \mathrm{kg}$ diet being the control group. Basal plasma PLP concentration was lower in both the $<0.5$ and $3 \mathrm{mg} / \mathrm{kg}$ diet groups than in control animals $(98 \pm 12,314 \pm 40$ and $514 \pm 56 \mathrm{mmol} / \mathrm{l}$, respectively). Basal plasma PL concentration was lower in the $<0.5 \mathrm{mg} / \mathrm{kg}$ diet group only $(60 \mathrm{nmol} / \mathrm{l}$ measured in pooled samples, $190 \pm 73 \mathrm{nmol} / \mathrm{l}$ and $235 \pm 63 \mathrm{mmol} / /$ for the $<0.5,3$ and $6 \mathrm{mg} / \mathrm{kg}$ diet groups, respectively). In both the $<0.5$ and $3 \mathrm{mg} / \mathrm{kg}$ diet groups PLP clearance was lower than in control rats $(0.158 \pm 0.025,0.131 \pm 0.040$ and $0.240 \pm 0.051 \mathrm{l} / \mathrm{h}$ per $\mathrm{kg} \mathrm{BW}$, respectively). In the $<0.5 \mathrm{mg} / \mathrm{kg}$ diet group only, PLP synthesis was more efficient than in control animals $(34 \pm 9.3 \%, 12.1 \pm 2.5 \%$ and $16.7 \pm 11.4 \%$ for the $<0.5,3$ and $6 \mathrm{mg} / \mathrm{kg}$ diet groups, respectively). In both the $<0.5$ and $3 \mathrm{mg} / \mathrm{kg}$ diet groups volume of distribution of PLP as well as of PL was larger than in controls. It is concluded that B-6 vitamer metabolism is influenced by vitamin B-6 status. The metabolic pathway involved (PLP synthesis and/or PLP degradation) was observed to depend on degree of vitamin B-6 deficiency.

\section{Introduction}

It is generally accepted that plasma pyridoxal-5'-phosphate (PLP) is not absorbed directly by tissue cells, but that pyridoxal (PL) is the ultimate transport form from plasma into cells [1-3]. All mammallian tissues examined so far exhibit PL-kinase activity [4]. Therefore, once absorbed PL can be (re)phosphorylated intracellularly to PLP. Intravenously administered PLP is cleared rapidly from plasma, most likely through dephosphorylation to PL [5].

Data from human and animal studies suggest that vitamin B-6 biokinetics depend on vitamin B-6 status [6-9]. In several experiments in guinea pigs [10], rats 
$[11-13]$ and man $[10,14-16]$ evidence has been found for a large vitamin B-6 compartment with slow turnover. From the biokinetic experiments performed on rats fed a purified diet containing adequate amounts of vitamin B-6 it was calculated that only approximately $15 \%$ of total body vitamin $B-6$ was covered in the model (submitted for publication). The experiments on rats fed graded levels of vitamin B-6 reported here were performed to investigate whether vitamin B-6 metabolism depends on vitamin B-6 status or whether changes in vitamin B-6 biokinetics can be attributed to an additional pool in the rat vitamin B-6 biokinetic model. This experiment was performed as part of an extensive study of vitamin B-6 metabolism in aging rats. The age-related effects on vitamin B-6 metabolism and vitamin B-6 biokinetics wili be reported elsewhere.

\section{Materials and methods}

\section{Animal handling}

Newly weaned male Wistar rats (Bor:WISW (SPF Cpb)) were obtained from F. Winkelmann, Borche, FRG, and assigned to three diet groups. All animals were fed a purified diet ad libitum, starting at an age of four weeks, with $0(n=55), 3$ or $6(n=120)$ mg pyridoxine $\cdot \mathrm{HCl}(\mathrm{PN} \cdot \mathrm{HCl})$ added per $\mathrm{kg}$ of basal diet (Table 1$)$. Diet groups were named after the amount of vitamin B-6 measured to be present in the diets ( $<0.5,3$ and $6 \mathrm{mg} / \mathrm{kg}$, respectively, see Table 1 ), with the $6 \mathrm{mg} / \mathrm{kg}$ diet group being the control group. The animals were housed in groups of five in stainless steel cages in a well ventilated room at $23 \pm 1{ }^{\circ} \mathrm{C}$, with a relative humidity of $50 \pm 10 \%$, and a light-dark cycle of $12 \mathrm{~h}$. All animals had free access to tap water.

After 7 months ten healthy animals from each diet group were randomly selected for biokinetic experiments and housed individually in plastic cages with sawdust

Table 1. Composition of the diet.

\begin{tabular}{lc}
\hline Ingredient & g/kg diet \\
\hline Catsein & 250 \\
DL-Methionine & 2 \\
Wheat starch & 578 \\
Cellulose (Solka Floc) & 50 \\
Vitamin B mixture & 2 \\
Jones-Foster minerals & 40 \\
Vitamin ADE K preparation & 4 \\
Choline chloride $50 \%$ & 4 \\
Soybean oil & 70 \\
\hline
\end{tabular}

1 For the exac composition regarding vitamins and minerals (except vitamin $B-6$ ), see ref. 17 .

2 To the basal diet pyridoxine. $\mathrm{HCl}$ was added at the following levels: $0 \mathrm{mg} / \mathrm{kg}, 3 \mathrm{mg} / \mathrm{kg}$ or $6 \mathrm{mg} / \mathrm{kg}$. Vitamin B-6 content measured (mean \pm SD): $0.3 \pm 0.2 \mathrm{mg} / \mathrm{kg}, 3.2 \pm 0.1 \mathrm{mg} / \mathrm{kg}$ and $5.9 \pm 0.9 \mathrm{mg} / \mathrm{kg}$, respectively. 
bedding. The animals were equipped with a permanent indwelling catheter in the right external jugular vein and were allowed at least one week of recovery. During the experiment plugging of catheters was observed in some animals. Complete data sets were collected from six rats on the $<0.5 \mathrm{mg} / \mathrm{kg}$ diet, from four rats on the $3 \mathrm{mg} / \mathrm{kg}$ diet and from six rats fed the control diet. The experimental protocol was approved by the Institute's Committee for Research on Experimental Animals.

\section{Experimental procedure}

During the experiment, exposure of PLP and pyridoxal (PL) solutions, blood and plasma to light was minimized. The day before dosing, blood from each animal was collected in vials containing $8 \%$ sodium-EDTA and centrifuged immediately at $2000 \mathrm{~g}$ and $4{ }^{\circ} \mathrm{C}$ for $20 \mathrm{~min}$. Plasma was transferred to another vial and stored at $-20^{\circ} \mathrm{C}$. On the day of the experiment the plasma was mixed with a solution containing an exactly known concentration of either PLP or PL (approximately $10 \mathrm{mmol} \mathrm{PLP} \cdot \mathrm{H}_{2} \mathrm{O}$ or $\mathrm{PL} \cdot \mathrm{HCl}$ per liter saline) at a ratio of $1: 1$. This mixture was incubated at $37^{\circ} \mathrm{C}$ in the dark for $45 \mathrm{~min}$. At 08.00 the animals were dosed intravenously with $800 \mu \mathrm{l}$ of plasma-vitamin B-6 mixture, each animal receiving its own plasma. $100 \mu \mathrm{l}$ of blood was collected in vials containing $8 \%$ sodium-EDTA immediately before dosing and at $15,30,45,60,90 \mathrm{~min}, 2,3,4,5,6,8,10,25$ and $33 \mathrm{~h}$ after dosing. Blood samples were stored at $0-4{ }^{\circ} \mathrm{C}$ in the dark and were centrifuged at $2000 \mathrm{~g}$ and $4{ }^{\circ} \mathrm{C}$ for $20 \mathrm{~min}$ within $4 \mathrm{~h}$. Plasma was transferred to another vial and stored at $-20^{\circ} \mathrm{C}$ until analysis. PLP was administered first, the second dose (PL) was administered after a one-week washout period.

\section{Analysis of samples}

Plasma was incubated with trichloroacetic acid (TCA) at $37^{\circ} \mathrm{C}$ for $30 \mathrm{~min}$ and centrifuged at $2000 \mathrm{~g}$ and $4{ }^{\circ} \mathrm{C}$ for $20 \mathrm{~min}$. The clear TCA extracts were used for both PLP and PL analysis. PLP concentration was measured by a modification of the L-tyrosine apodecarboxylase assay of Chabner \& Livingstone [18]. PL concentration was measured by a modification of the HPLC method described by Schrijver et al. [19]. Analysis was performed in a room illuminated with yellow fluorescent light.

\section{Biokinetic analysis}

The observed plasma concentration-time curves were fitted with a standard nonlinear regression program BMDP3R (BMDP Statistical Software, Los Angeles, CA, USA) using an exponential function:

$$
C(t)=A_{b}+\Sigma_{i}^{n}=1\left[A_{j} \cdot \exp \left(-\lambda_{i} \cdot t\right)\right]
$$

where $C(t)$ is plasma concentration at time $t$ after dosing, $A_{b}$ is baseline plasma concentration, $A_{i}$ are the exponential constants and $\lambda_{i}$ are the exponential 
coefficients. PLP curves after PLP dosing in $<0.5$ and $3 \mathrm{mg} / \mathrm{kg}$ diet groups were adequately described by a triexponential curve, i. e. $n=3$. All other curves, including PLP after PLP dosing in control rats, were biexponential, i.e. $n=2$. For all plasma concentration values a weighting factor equal to the inverse of the error variance was used in the curve fitting procedure. The exponential constants $A_{j}$ and the exponential coefficients $\lambda_{i}$ were used to calculate various biokinetic parameters using wellestablished formulae [20]. The area under the plasma concentration-time curve (AUC) was calculated as $\Sigma_{i}^{n}=1\left(A_{i} / \lambda_{i}\right)$. Total plasma clearance $(C l)$ was calculated as dose (D) divided by AUC. Volume of the central compartment $\left(V_{1}\right)$ was calculated as $D / \Sigma_{i}^{n}=1\left(A_{i}\right)$. Area-derived total volume of distribution ( $\left.V_{\text {area }}\right)$ was calculated as $\mathrm{D} /\left(\mathrm{AUC} \cdot \lambda_{n}\right)$, with $\lambda_{n}$ being the final exponential constant (i.e. $\mathrm{i}=\mathrm{n}$ ) derived through fitting of the corresponding curve. $\mathrm{D}, \mathrm{Cl}, \mathrm{V}_{1}$, and $\mathrm{V}_{\text {area }}$ presented in the tables are corrected for body weight (BW). Subscripts PL or PLP denote whether parameters are descriptive of PL or PLP biokinetics. The area under the first moment curve (AUMC) was calculated as $\Sigma_{i}^{n}=1\left(A_{i} / \lambda_{i}^{2}\right)$. AUMC was used to calculate the mean residence time (MRT) in the central compartment; MRT was calculated as AUMC/ALC. AUC is proportional to the total amount of substance dosed into the biokinetic system, irrespective of the shape of the plasma concentration-time curve, as long as total plasma clearance is constant. With this proportionality between AUC and amount, the percentage of PL dosed phosphorylated to PLP, and the percentage of PLP dosed dephosphorylated to PL, can be estimated: by comparison of corresponding AUC-values (if necessary corrected for difference in dose size administered). The percentage of PL dosed phosphorylated to PLP ( $\left.F_{P L \rightarrow P L P}\right)$ is thus calculated as:

\section{$\left(A U C_{P L P}\right.$ after PL dosing $/ A U C_{P L P}$ after PLP dosing $) \cdot\left(D_{P L P} / D_{P L}\right) \cdot 100 \%$}

The percentage of PLP dosed dephosphorylated to PL ( $F_{P L P} \rightarrow$ PL $)$ is calculated in an analogous way:

$$
\text { (AUCPL after PLP dosing } \left./ A U C_{P L} \text { after PL dosing }\right) \cdot\left(D_{\mathrm{PL}} / \mathrm{D}_{\mathrm{PLP}}\right) \cdot 100 \%
$$

Analysis of variance (ANOVA) was performed on the biokinetic parameters calculated for the three diet groups using the GENSTAT statistical package. Standard error of difference (SED) and significance of diet effect $(P<0.05)$ are given in the tables.

\section{Results}

Fig. 1 shows the average plasma PLP and PL response after an intravenous dose of PLP, Fig. 2 after an intravenous dose of PL. Average curves for all diet groups were comparable in shape and concentration up till $36 \mathrm{~h}$ after dosing. Only for the $<0.5 \mathrm{mg} / \mathrm{kg}$ diet group a clear further decrease in plasma concentration was noted. 

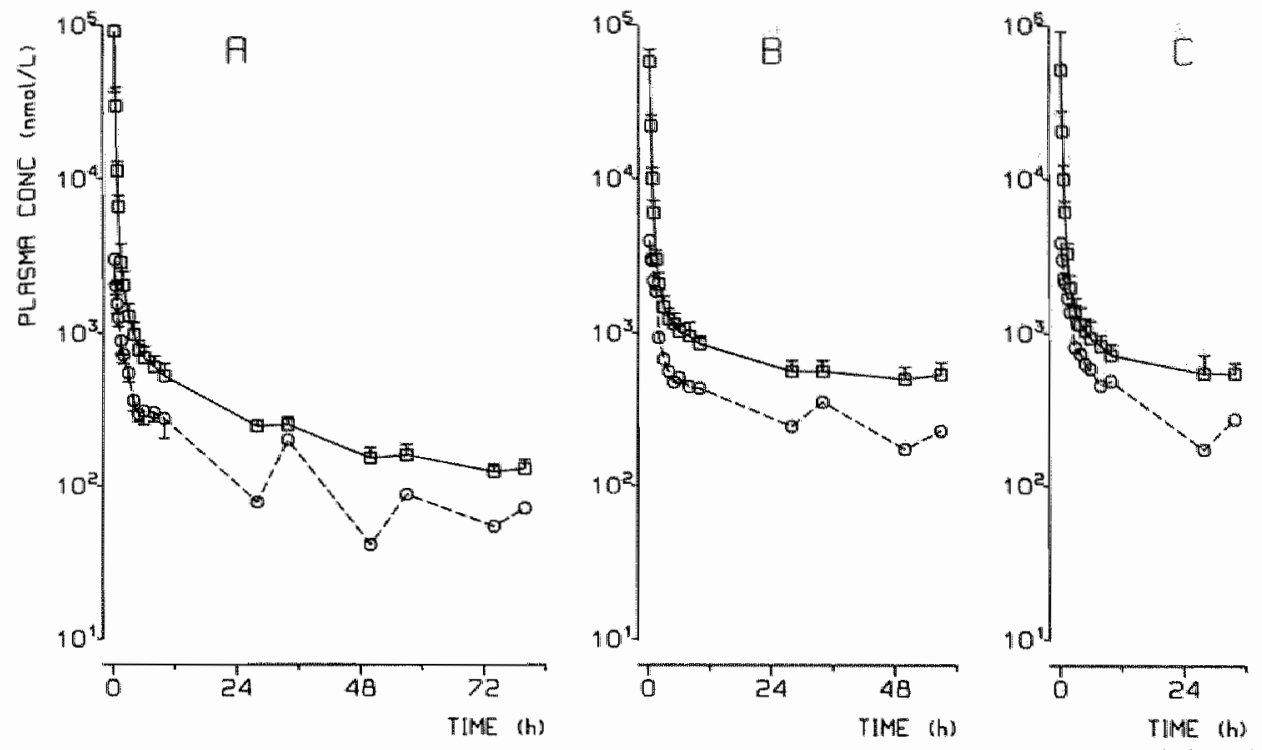

Fig. 1. Plasma PLP and PL response (mean $\pm S D$ ) after an intravenous dose of PLP. $A,<0,5 \mathrm{mg} / \mathrm{kg}$ diet; $\mathrm{B}, 3 \mathrm{mg} / \mathrm{kg}$ diet; $\mathrm{C}, 6 \mathrm{mg} / \mathrm{kg}$ diet (control animals); squares, PLP concentration; circles, $\mathrm{PL}$ concentration. Plasma PL response was measured in pooled samples, except for the $<0.5 \mathrm{mg} / \mathrm{kg}$ diei group up to $12 \mathrm{~h}$ after dosing.
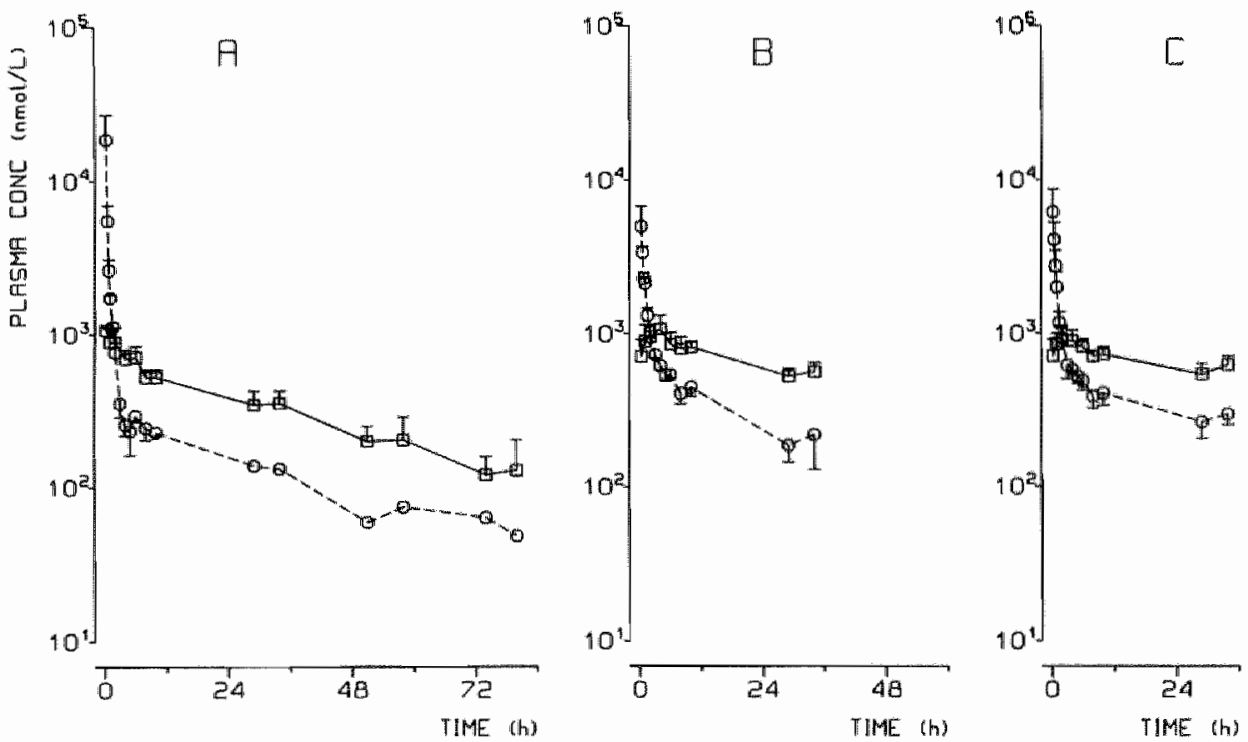

Fig. 2. Plasma PLP and PL response (mean \pm SD) after an intravenous dose of PL. A, $<0.5 \mathrm{mg} / \mathrm{kg}$. diet; $\mathrm{B}, 3 \mathrm{mg} / \mathrm{kg}$ diet; $\mathrm{C}, 6 \mathrm{mg} / \mathrm{kg}$ diet (control animals); squares, PLP concentration; circles, PL. concentration. Plasma PL response from $24 \mathrm{~h}$ after dosing onwards was measured in pooled samples in the $<0.5 \mathrm{mg} / \mathrm{kg}$ diet group. For clarity sake some. PLP concentrations measured before $t=10 \mathrm{~h}$ after dosing have been deleted. 
Biokinetic parameters of PLP and PL calculated for each separate curve are shown in Tables 2 and 3, respectively. Basal plasma concentration of both PLP and PL was significantly lower in the $<0.5 \mathrm{mg} / \mathrm{kg}$ diet group. Both the 0.5 and $3 \mathrm{mg} / \mathrm{kg}$ diet groups showed smaller $\mathrm{Cl}_{\mathrm{PLP}}$, smaller $\lambda_{\mathrm{n}, \mathrm{PLP}}$ and larger $\mathrm{V}_{\text {area, }} \mathrm{PLP}$ than control animals. Cl $\mathrm{PL}$ did not differ significantly between diet groups, but the $<0.5$ and $3 \mathrm{mg} / \mathrm{kg}$ diet groups showed a tendency towards larger $V_{\text {area, }}$ PL and smaller $\lambda_{n}$ PL than controls. $V_{1, P L}$ was significantly larger for the $3 \mathrm{mg} / \mathrm{kg}$ diet group only; no significant difference was observed between the animals on diets $<0.5$ and $6 \mathrm{mg} / \mathrm{kg}$. $\mathrm{V}_{1, \mathrm{PLP}}$, on the other hand, was comparable for all diet groups. Generally, MRT values were larger in animals on the $<0.5 \mathrm{mg} / \mathrm{kg}$ diet than in control animals, but calculated MRT values showed large variation within diet groups. FPL $\rightarrow$ PLP was larger in animals fed the $<0.5 \mathrm{mg} / \mathrm{kg}$ diet than in control rats. Data for F PLP $\rightarrow$ PL were limited, but wallues found were not significantly different from unity.

Table 2. Büokinetic parameters describing plasma PLP disposition (means).

\begin{tabular}{|c|c|c|c|c|c|}
\hline Parameter & $\begin{array}{c}<0.5 \mathrm{mg} / \mathrm{kg} \\
(n=6)\end{array}$ & $\begin{array}{l}3 \mathrm{mg} / \mathrm{kg} \\
(n=4)\end{array}$ & $\begin{array}{l}6 \mathrm{mg} / \mathrm{kg} \\
(n=6)\end{array}$ & SED 1 & $p$ \\
\hline $\mathbb{D}_{\mathrm{PL}}(\mu \mathrm{mol} / \mathrm{kg} \mathrm{BW})$ & 7.71 & 7.59 & 7.94 & 0.37 & $\mathrm{NS}^{2}$ \\
\hline basal plasma PLP (nmol/l) & 98 & 314 & 514 & 38 & $<0,001$ \\
\hline $\mathrm{Cl}_{\mathrm{PL}}(\mathrm{l} / \mathrm{h}$ perkg BW $)$ & 0.158 & 0.131 & 0.240 & 0.025 & $<0.001$ \\
\hline$\lambda_{p} \mathrm{p}(1 / \mathrm{h})$ & 0.050 & 0.035 & 0.338 & 0.035 & $<0.001$ \\
\hline$\sqrt{1, P L P}(\mathrm{l} / \mathrm{kg} \mathrm{BW})$ & 0.083 & 0.068 & 0.096 & 0.015 & NS \\
\hline$V_{a r e d p l}(1 / \mathrm{kg} \mathrm{BW})$ & 3.52 & 3.98 & 0.76 & 0.73 & $<0.001$ \\
\hline$M \mathbb{R T} T_{\mathrm{P} P(h)}$ & 7.11 & 14.84 & 1.03 & 3.35 & 0.0104 \\
\hline$F \mathrm{PL} \rightarrow \mathrm{PLP}(\%)$ & 34.7 & 12.1 & 16.7 & 5.6 & 0.003 \\
\hline
\end{tabular}

1 Standard error of difference (min-max), ANOVA.

2 Not significant.

Table 3. Biokinetic parameters describing plasmat PL disposition (means).

\begin{tabular}{|c|c|c|c|c|c|}
\hline Parameter & $\begin{array}{c}<0.5 \mathrm{mg} / \mathrm{kg} \\
(n=6)\end{array}$ & $\begin{array}{l}3 \mathrm{mg} / \mathrm{kg} \\
(m=4)\end{array}$ & $\begin{array}{l}6 \mathrm{mg} / \mathrm{kg} \\
(n=6)\end{array}$ & SED 1 & $P$ \\
\hline $\mathrm{D}_{\mathrm{BL}}($ (umol/kg BW) & 10.03 & 9.88 & 10.28 & 0.49 & $\mathrm{NS}^{2}$ \\
\hline Basal plasma PL (nmol/l) & $60^{3}$ & 190 & 235 & 33 & $<0.001$ \\
\hline $\mathrm{Cl}_{\mathrm{PL}}(\mathrm{l} / \mathrm{h}$ per kg BW$)$ & 1.08 & 1.03 & 1.30 & 0.14 & NS \\
\hline$\lambda_{\mathrm{D}} \mathrm{PL}(1 / \mathrm{h})$ & 0.116 & 0,118 & 0.240 & 0.053 & 0.034 \\
\hline$\sqrt{M}, P L(1 / k g B W)$ & 0.99 & 1.78 & 1.14 & 0.12 & $<0.001$ \\
\hline$V, P L(1 / k g B W)$ & 10.7 & 10.0 & 6.0 & 1.8 & 0.029 \\
\hline Mktp $(h)$ & 4.7 & 7.6 & 2.7 & 1.6 & 0.027 \\
\hline FPLP $\rightarrow$ PL $(\%)$ & 126 & $1.59^{3}$ & $128^{3}$ & 26 & NS \\
\hline
\end{tabular}

\footnotetext{
Standard error of difference (min-max), ANOVA.

2Not significant.

Pooled samples.
} 
Basal plasma PLP concentration was not influenced by sampling time (data not shown). Since the corresponding PL level was measured in pooled samples only, no definitive conclusions could be drawn from these limited data. No significant day-today variation was noted for either basal PLP or PL level in plasma (data not shown).

\section{Discussion}

The animals used for the biokinetic experiment had been on their respective feed regimen for 7 months from weaning. When young rats are put on a low vitamin B-6 diet plasma PLP drops to a new and low steady-state level in approximately two weeks [21]. However, body stores are probably not depleted this fast. In an experiment on germfree rats uniform labeling of total body vitamin B-6 was demonstrated for the first time [13]. Approximately 75 to $80 \%$ of total isotope in the body was present in striated muscle tissue. In striated muscle tissue vitamin B-6 is mainly present as PLP bound to glycogen phosphorylase $[22,23]$. In mice striated muscle glycogen phosphorvlase turnover was assessed by measuring disappearance of glycogen phosphorylase-bound radiolabeled PLP. Depending on the muscle tissue examined a half-life of 6 to 11 days was found $[24-26]$. Because of the likely correlation with body size the authors suggested that muscle glycogen phosphorylase turnover in rats might be slower than in mice. Muscle glycogen phosphorylase turnover probably is a reasonable approximation of the turnover rate of the large vitamin B-6 compartment with slow turnover found in experiments with radiolabeled vitamin B-6 [10-16]. Depletion rate of vitamin B-6 body stores, largely present as glycogen phosphorylase-bound PLP, is expected to be approximated by glycogen phosphorylase turnover rate. This implies musc'e vitamin B-6 pool will reach steady state considerably later than plasma PLP after switching to a vitamin B-6 deficient diet.

4'-Deoxypyridoxine, an antimetabolite of vitamin B-6, is frequently used to induce vitamin B-6 deficiency quickly. However, evidence has been presented showing that the in vivo effect of 4 "-deoxypyridoxine may involve more than simple competitive inhibition of vitamin B-6 dependent enzymes [27]. As the main interest was vitamin B-6 biokinetics, not vitamin B-6 deficiency symptoms, a substance influencing vitamin B-6 metabolism could not be used. Therefore differences in vitamin B-6 status were induced through manipulation of dietary vitamin B-6 level only. The control diet, containing $6 \mathrm{mg} \mathrm{PN} \cdot \mathrm{HCl} / \mathrm{kg}$, was formulated to approach the rat diet recommendation for nutritional studies by the American Instititute of Nutrition [28]. The amount of vitamin B-6 provided with this diet is considered to be higher than minimal vitamin B-6 requirement of rats. An experimental diet containing $50 \%$ of recommended vitamin B-6 level ( $3 \mathrm{mg} \mathrm{PN} \cdot \mathrm{HCl} / \mathrm{kg}$ ) was included, which is slightly above rat minimal vitamin B-6 requirement [29-32]. Furthermore, a diet providing low dietary vitamin B-6 was used, consisting of basal diet without vitamin B-6 added (Table 1). This latter diet was not completely clevoid of vitamin 
B-6 activity, probably due to the presence of vitamin B-6 in the casein used as source of protein.

Judged by basal plasma PLP and PL concentrations measured (Tables 2 and 3 , respectively), vitamin B-6 status was indeed lower in the animals on the $<0.5$ and $3 \mathrm{mg} / \mathrm{kg}$ diets. Although plasma PLP differed significantly between any two diet groups, plasma PL was significantly lower in animals fed the $<0.5 \mathrm{mg} / \mathrm{kg}$ diet only, suggesting that mechanisms regulating plasma PLP are different from those regulating plasma $\mathrm{PL}$. In our experimental animals baseline plasma PL concentration was lower than baseline plasma PLP concentration in all experimental groups, which is in agreement with an earlier study on the same strain of rats [17]. However, other studies show similar plasma concentrations for both vitamers [33] or higher plasma PL than plasma PLP levels [34].

The biokinetic approach used in this experiment, calculation of biokinetic parameters from plasma (dis)appearance curves through non-compartmental analysis, implies that body pools and substance flows (for example dephosphorylation of PLP, cellular uptake of PL) can not be ascribed to discrete body tissues (for example liver, erythrocytes). A different biokinetic model of vitamin B-6 metabolism was described by Coburn and Townsend [35].

Combining body compartments with independently verified significant impact on vitamin B-6 metabolism, as obtained in rat experiments (partly in vitro) by other research groups, a multicompartment model of rat vitamin B-6 metabolism consisting of 25 pools was developed. Using this type of biokinetic model it is (theoretically) possible to indicate which tissue(s) attribute(s) most to the parameter of interest.

$\mathrm{Cl}_{\mathrm{PLP}}$ was found to be lower in both the $<0.5$ and $3 \mathrm{mg} / \mathrm{kg}$ diet groups than in control rats (Table 2). Lower $\mathrm{Cl}_{\text {PLP }}$ can be attributed to a lower PLP elimination rate. Consequently, MRT PLP (after PLP dosing) was larger in animals fed the $<0.5$ and the $3 \mathrm{mg} / \mathrm{kg}$ diet than in animals fed the control diet. F $\mathrm{PL} \rightarrow \mathrm{PLP}$ was found to be significantly higher in the $<0.5 \mathrm{mg} / \mathrm{kg}$ diet group only. Apparently for the $<0.5 \mathrm{mg} / \mathrm{kg}$ group not only PLP elimination rate was lower but also PLP synthesis rate was higher. Both $\mathrm{Cl}_{\mathrm{PLP}}$ and $\mathrm{FPL}_{\mathrm{PLLP}}$ could theoretically be influenced by plasma PL disposition. Plasma PLP was found to be completely eliminated by dephosphorylation to $\mathrm{PL}$ (results subrnitted for publication). A change in $\mathrm{Cl}_{\mathrm{PL}}$ could therefore induce a change of $\mathrm{Cl}_{\mathrm{PLP}}$ in the same direction and a change in $\mathrm{F}_{\mathrm{PL} \rightarrow \mathrm{PLP}}$ in the opposite direction. In our experimental animals, however, $\mathrm{Cl}_{\mathrm{PL}}$ was not found to be significantly different between diet groups (Table 3). As a consequence of similar $\mathrm{Cl}_{\mathrm{PL}}$ values for all diet groups diet-related differences in $M_{P L}$ were less pronounced than diet-related differences in MRT PLP (Table 2). $F P L P \rightarrow P L$ was not significantly different from unity in any diet group, although variation in values observed was large (Table 3 ). From these FPLP $\rightarrow$ PL values it was concluded that in all animals, irrespective of vitamin B-6 intake, plasma PLP was probably eliminated completely by metabolism, i. e. dephosphorylation to PL.

Changes in clearance can be ascribed to changes in volume of distribution on the one hand and changes in rate constants on the other. Therefore, $V_{1}, V_{\text {area }}$ and 
$A_{n}$, both of PLP and PL, are to be considered as well. In the vitamin B-6 biokinetic experiments performed the terminal part of the curve was observed to have the largest impact on $A U C$ and hence on clearance. $V_{1}$, PLP did not differ between diet groups, but $V_{\text {area, }} P L P$ did, with both the $<0.5$ and $3 \mathrm{mg} / \mathrm{kg}$ diet groups showing significantly larger values than controls. A larger value for

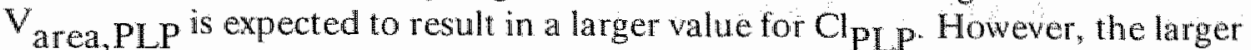
$V_{\text {area,PLP }}$ is more than offset by a lower $\lambda_{n, P L P}$ in these diet groups, resulting in a lower overall value for $\mathrm{Cl}_{\mathrm{PLP}}$. Although $\mathrm{Cl}_{\mathrm{PL}}$ was not found to be influenced by dietary vitamin $B-6$ intake, $V_{1, P L}, V_{\text {area, }} \mathrm{PL}$ and $\lambda_{\mathrm{n}} \mathrm{PL}$ were. $\mathrm{V}_{1, \mathrm{PL}}$ was significantly different from controls in the $3 \mathrm{mg} / \mathrm{kg}$ animals only. No explanation is available for this observation. $V_{\text {area, }} P$ was larger in both the $<0.5$ and $3 \mathrm{mg} / \mathrm{kg}$ diet groups than in control rats. The concomitantly observed lower $\lambda_{n, P L}$ in these animals resulted in comparable $\mathrm{Cl}_{\mathrm{PL}}$ values for all diet groups.

Relations between vitamin B-6 status and vitamin B-6 kinetics have been reported before. In rat experiments with radiolabeled $P N$ higher retention of label was observed $[6,7]$. In a short-term feeding experiment on female Wistar rats at an age of 3 months we observed $\mathrm{Cl}_{\text {PLP }}$ to be lower in animals that had consumed a diet low in vitamin B-6 for three weeks than in controls which were fed an adequate diet throughout the experiment [8]. These data are in agreement with the observations reported here. In man ClPLP has been found to be lower after supplementation with intravenously administered PN (122 $\mu \mathrm{mol} /$ day) for four weeks [9]. The observed lower value for $\mathrm{Cl}_{P L P}$ was attributed to the concomitantly observed smaller volume of distribution; $\lambda_{\mathrm{n}}, \mathrm{PL}$ P was not influenced by supplementation. The authors suggested that volume of distribution of administered PLP is influenced by the extent of previous saturation of the body store with PLP, i.e. a higher extent of body store saturation would give rise to a lower volume of distribution. In our experiments on rats $V_{\text {area }}$ of both PL and PLP were found to be higher in animals fed the $<0.5$ or $3 \mathrm{mg} / \mathrm{kg}$ diet, which is in line with the observations in man. However, as $\lambda_{n}$ of both PL and PLP was dependent on vitamin B-6 intake of the animals too, observations on $\mathrm{Cl}_{\mathrm{PL}}$ and $\mathrm{Cl}_{\mathrm{PLP}}$ in our experimental animals differed from those in man.

Using the values found for basal plasma concentration and $V_{\text {area }}$ for both $\mathrm{PL}$ and PLP the amount of total body vitamin B-6 included in the model can be estimated. For the control animals this amounts to approximately $1.8 \mu \mathrm{mol} / \mathrm{kg} \mathrm{BW}$, which is very low. In the aforementioned experiment, in which uniform labeling of total vitamin B-6 body pool was accomplished in germfree 6 -month-old rats, a value of $16.2 \pm 0.8 \mu \mathrm{mol} / \mathrm{kg} \mathrm{BW}$ was found [13]. Additional vitamin B-6 compartments included in the model by using animals with reduced vitamin B-6 intake can be approximated by multiplying the values found for $V_{\text {area, }} P L$ and $V_{\text {area,PLP }}$ in the $<0.5 \mathrm{mg} / \mathrm{kg}$ diet group by basal plasma PL and PLP concentration observed in control animals. This results in an amount of total body vitamin B-6 included in the model of approximately $4.3 \mu \mathrm{mol} / \mathrm{kg} \mathrm{BW}$. By feeding a low-vitamin B-6 level diet instead of a vitamin B-6 adequate diet an 
additional rat vitamin B-6 compartment is included, but still a major fraction of total body vitamin B-6 is not covered in the biokinetic experiment. Half-time of plasma PLP in the terminal part of the concentation-time curve abserved in animals fed the $<0.5 \mathrm{mg} / \mathrm{kg}$ diet was approximately $14 \mathrm{~h}$, which is much shorter than the observed half-time of glycogen phosphorylase turnover in mice striated muscle [24-26]. Most likely even in this low-vitamin B-6 diet group the striated muscle compartment of vitamin B- 6 is not included in our biokinetic model.

Extracellular fluid volume is estimated at $0.18-0.22 \mathrm{~L} / \mathrm{kg} \mathrm{BW}$ for man [36]. Assuming a similar value for rats, $V_{1}$,PLP was found to be considerably smaller than extracellular fluid volume in all diet groups (Table 2). It was concluded that plasma PLP is not taken up into (tissue) cells directly, not even in animals with prollonged severely reduced vitamin $\mathrm{B}-6$ intake. $\mathrm{V}_{1}, \mathrm{PL}$ largely exceeded extracellular fluid volume in all diet groups, with only the $3 \mathrm{mg} / \mathrm{kg}$ diet group showing larger values than controls (Table 3 ). Therefore it was concluded that PL uptake into (tissue) cells takes place in all diet groups, but the influence of vitamin B-6 status remains unclear.

In all animals $V_{\text {area, }} P L$ was very large (much more than 1 liter $/ \mathrm{kg} \mathrm{BW}$ ), with the $<0.5$ and $3 \mathrm{mg} / \mathrm{kg}$ diet groups showing larger values than the $6 \mathrm{mg} / \mathrm{kg}$ diet group (Table 2). This can be explained by the occurrence of extensive tissue binding after PL uptake into cells, and more so in animals with lowered vitamin B-6 intake. Tissue binding most likely involves phosphorylation to intracellular PLP. More extensive tissue binding, i. e. synthesis of the active B-6 vitamer PLP, in animals on prolonged reduced vitamin B-6 intake is to be expected.

The observed higher FPL $\rightarrow$ PLP in the $<0.5 \mathrm{mg} / \mathrm{kg}$ diet group only is very interesting (Table 2). Apparently only at this low intake level metabolism is adjusted as to be more efficient in the synthesis of active vitamin B-6, i.e. PLP. In both the $<0.5$ and $3 \mathrm{mg} / \mathrm{kg}$ diet groups $\mathrm{Cl}_{\mathrm{PLP}}$ is lower than in controls resulting in higher retention of active vitamin B-6 or PLP. Vitamin B-6 metabolism is influenced by vitamin B-6 status, but the metabolic pathway involved (PLP synthesis or PLP elimination) seems to be dependent on the degree of vitamin B-6 deficiency.

Patients with chronic liver disease or with uremia are prone to show a low plasma PLP level [37-39]. When studying vitamin B-6 disposition in these patients only PN $[38,39]$ or both PN and PLP [37] had been dosed. The approach used in our rat experiments, dosing PLP and PL intravenously, could be of value to gain more insight into the changes occurring in vitamin B-6 biokinetics in patients with observed changes in vitamin B-6 metabolism.

\section{References}

1. Anderson BB, Fulford-Jones CE. Child JA, Beard MEJ, Bateman CJT. Conversion of vitamin B-6 compounds to active forms in the red blood cell. J Clin Invest 1971;50: 1901-9.

2. Suzue R, Tachibana M. The uptake of pyridoxal phosphate by human red blood cells. I Vitaminol 1.979:16:164-71. 
3. Lumeng L. Li T-K. Mammalian vitamin B-6 metabolism, regulatory role of protein-binding and the hydrolysis of pyridoxal -5 -phosphate in storage sind transport. $1 \mathrm{n}$ : GP Tryltates, ed: Vitum B-6 metabolism and role in growth. Westpont: Food \& Nutrition Press, 1980:27-52.

4. MeCormick DB, Gregory ME, Snell EE Pyridoxal phosphokinases. 1. Assay, distribution, purification and properties. I Biol Chem 1961:236:2076-84.

5. Lumeng L. Schenker S, Li T-K, Brashear RE, Compton MC Clearance and metabolism of plasma pyridoxat-5"-phosphate in the dog. J Lab Clin Med 1984; 103: 59-69.

6. Johansson $S$, Lindstedt $S$, Register U. Metabolism of labeled pyridoxine in the rat. Am J Physiol 1966;210: 1086-95.

7. Trumbo PR, Gregory III JF. Metabolic utilization of pyridoxine-13-glucoside in rats: influence of vitamin $B-6$ status and route of administration. J Nutr 1988;118:1336-42.

8. Bode W, Hekman $P$, van den Berg $H$. Influence of vitamin B 6 nutritional status upon plasma kinetics of PLP after I.V. dosing to rats. In: Korpela T, Christen P, eds. Biochemistry of vitamin B-6. Proceedings of the 7 th international congress on chemical and biological aspects of witamin B-6 catalysis. Basel: Birkhäuser Verlag, 1987: 407-10.

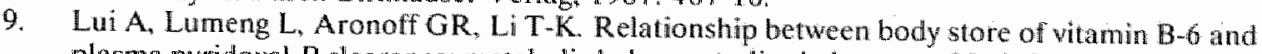
plasma pyridoxal-P clearance: metabolic balance studies in humans. J Lab Clin Med 1985; 106: $491-7$.

10. Coburn SP, Mahuren JD, Etbelding WF, Townsend DW, Hachey DL, Klein PD. Measurement of vitamin B-6 kinetics in vivo using chronic administration of labelled pyridoxine. In: Chemical and Biological Aspects of Vitamim B-6 Catalysis, Part A. New York: Alan R. Liss, 1984: 43-54.

11. Cox SH, Murray A, Boone 1U. Metabolism of tritium-llabeled pyridoxine in rats. Proc Soc Exp Biol Med 1962;109: 242-4.

12. Shane B. Vitamin B-6 metabolism and tumover in the ethanol-fed rat. J Nutr 1982;112:610618.

13. Coburn SP, Mahuren JD, Wostmann BS, Snyder DL, Townsend DW. Role of intescinal microflora in the metabolism of vitamin B-6 and 4 "-deoxypyridoxine examined using germ/ree. guinea pigs and rats. J Nutr 1989;119:181-8.

14. Tillotson JA, Saubertich HE, Baker EM, Canham JE. Use of carbon-14 labeled vitamins in human nutrition studies: pyridoxine. In: Proceedings of the Seventh International Congress of Nutrition. Vol. 5. Physiology and Biochemistry of Food Components. Oxlord: Perganon Press. 1966: 554-7.

15. Johansson $S$, Lindstedt $S$, Register U, Wadström L. Studies on the metabolism of labeled pyridoxine in man. Am J Clin Nutr 1978;18: 185-96.

16. Shame B. Vitamin B-6 and blood. In: Human Vitamin B-6 Requirements. Washington DC: National Academy of Sciences, 1978: 111-128.

17. van den Berg $\mathbf{H}$, Bogaards JJP. Vitamin B-6 metabolism in the pregnant rat: effect of progesterone on the (re)distribution in maternal vitamin B-6 stores. J Nutr 1987:117: 1866-74.

18. Chabner B, Livingstone D. A simple enzymatic assay for pyridoxal phosphate. Anal Biochem $1970 ; 34: 413-23$.

19. Schrijver J, Speek AJ, Schreurs WHP. Semi-automated fluorometric determination of pyridoxal5 -phosphate (vitamin B-6) in whole blood by high-performance liquid chromatography. Int I Vil Nutr Res 1981:51:216-22.

20. Gibaldi M. Perrier D. Pharmacokinetics, 2nd ed. New York: Marcel Dekker, 1982: 45-111, 409-24.

21. Cochary EF, Gershoff SN, Sadowski JA. Aging and vitamin B-6 depletion: effects on plasma pyridoxal-5" - phosphate and erythrocyte aspartate aminotransferase activity coefficitents in rats. Am J Clin Nutr 1990;51: 446-52.

22. Black AL. Guirard BM, Snell EE. Increased muscle phosphorylase in rats fed high level of vitamin B-6.J Nutr 1977; 107: 1962-8.

23. Russell LE, Bechtel PJ, Easter RA. Effect of deficient and excess diellary vitamin B-6 on amino transaminase and glycogen phosphorylase activity and pyridoxal phosphate content in iwo muscles from postpubertal gilis. $J$ Nutr 1985;115:1124-35.

24. Butler PE, Cookson EJ, Beynon RJ. The turnover of skeletal muscle giycogen phosphorylase studied using the cofactor, pyridoxal phosphate, as a specific label. Biochim Biophys Acta $1985 ; 847: 316-23$. 
25. Beynon RU, Famursil D, Cookson EJ. Tumover of skeletal muscle glycogen phosphorylase. Biomed Biochim Acta 1986:45:1619-25.

26. Cookson EJ, Beynon R. Further evaluation of cofactor as a lurnover label tor glycogen phosphorylase Int J Biochern 1989:21:975-82.

27. Coburi SP, Mahuren JD. Schalienbrand WE, Wostmann BS, Madsen D. Effects of vitamin B-6 deficency and -deoxypyridoxine on pyridoxal phosphate concentration, pyrdoxine kinase and other aspects of metabolism in the rat. I Nutr 1981;111:391-8.

28. Bier JG, Stoewsand GS, Briggs GM, Philips RW, Woodand IC, Knapka JJ. Report of the Ameriean Institute of Nutrition. Ad hoc committee on standards for nutritional studies. J Nutr $1977 ; 107: 1340-8$.

29. Driskell $J A$, Kirksey $A$. The cellular approach to the determination of pyridoxine requirements in pregnant and non pregnant rats. J Nutr 1971:101:661-8.

30. Driskell $A_{\text {, }}$ Strickland $L A$, Poon $C H$, Foshnee DP. The vitamin B-6 requirement of the male rat as determined by behavioral patterns, brain pyridoxal phosphate and nucleic acid composition and erythrocyle alanine aminotransferase activity. I Nutr 1973:103:670-80.

31. Lumeng $L$, Ryan MP, Li T-K. Validation of the diagnostic value of plasma pyridoxal-5"phosphate measurements in vitamin B-6 nutrition of the rat. J Nutr 1978;108: 545-53.

32. Driskell JA, Chrisley BM, Pierotti JA, Hefferan TE. High-pertormance liquid chromatograpthic analysis of vilamin B-6 componerts in tissues and status assessment. Nutr Rep Int 1987,35: $1247-59$.

33. Gregory III JF, Litherland SA. Efficacy of the rat bioassay for the detemination of biologically avalable vitamin $B-6$. J Nutr 1986; $116: 87-97$.

34. Sampson DA, O Connor DK. Response of B-6 witamers in plasma, erythrocytes and tissues to vitamin B-6 depletion and repletion in the rat. J Nutr 1989;119: 1940-8.

35. Coburn SP. Townsend DW. A multicompartment model of vitamin B-6 metabolism. Progr Food Nutr Sci 1988;12:227-42.

36. Rowland M. Tozer TN. In: Clinical Pharmacokinetics, Concepts and Applications. Philadelphia: Lea \& Febiger, 1980: 4.1.

37. Milchell D, Wagner C. Stone WJ, Wilkinson GR, Schenker MD. Abnormal regulation of plasma pyridoxal-5'-phosphate in patients with liver disease. Gastroenterology 1976;71:1043-9.

38. Spannuth Jr CL. Warnock $\mathrm{LG}_{4}$ Wagner C, Stone WJ. Increased plasma cllearance of pyridoxall-5'phosphate in vitamin B-6 deficient uremic man. J Lab Clin Med 1977:90: 632-7.

39. Henderson JM, Codner MA, Hollins B, Kutner MH, Merrill A.H. The fasting B-6 vitamer profile and response to a pyridoxine load in normal and cirhotic subjects. Hepatology 1986;6: 464-71. 


\title{
Behavioral testing in nutrient research: long-term graded vitamin B-6 intake in male and female Wistar rats
}

\author{
Wilhelmina Bode and Herman B.W.M. Koëter
}

\section{Abstract}

Behavioral response was evaluated in male and female Wistar rats fed from weaning a purified diet containing $250 \mathrm{~g}$ casein and either $<0.5,3$ or $6 \mathrm{mg}$ pyridoxine $\cdot \mathrm{HCl}$ per $\mathrm{kg}$. At an age of 6 months ten animals from each diet and sex group were tested. The animals were retested at an age of 18 months. Reflexes were evaluated in the air righting test, sensory and motor function in the negative geotaxis test and the rotarod balancing test, and locomotor activity and motivational state/emotionality was evaluated in the general activity test. The auditory startle test was used to evaluate non-associative learning, associative learning was evaluated in the active avoidance test. No diet-related difference in performance was observed in any test. This is suggested to be rellated to the observation that brain tissue is comparatively spared in vitamin B-6 deficiency. Turning behavior, but not turning performance, differed between young and old rats in the negative geotaxis test. The percentage of animals that could right in the air righting test tended to decrease with age (from $94 \%$ to $76 \%$ ). Delay time between stimulus and maximum response in the auditory startle test was on average $40 \mathrm{~ms}$ at an age of 6 months, but $50 \mathrm{~ms}$ at an age of 18 months. Female rats showed better performance in the active avoidance test than males al both 6 and 18 months of age.

\section{Introduction}

Aging seems to be accompanied with an increase of biochemical vitamin B-6 status parameter values suggestive of less than adequate vitamin B-6 nutriture, i. e. low plasma pyridoxal-5'-phosphate (PLP) levels [1-3]. Observational studies on nutrient consumption of the aged generally indicate low dietary vitamin B-6 intake [4-6]. The B-6 vitamer PLP is a cofactor of various transaminases and decarboxylases, and as such is involved in neurotransmitter synthesis [7]. Whether the observed age-related changes in vitamin B-6 status parameter values are somehow causally related to cognitive function loss generally associated with old age remains to be established. 
In this study behavioral consequences of long-term decreased vitamin B-6 intake were examined in male and female Wistar rats fed purified diets containing graded levels of vitamin $\mathrm{B}-6$ from weaning.

\section{Materials and methods}

\section{Animals and experimental protocol}

A detailed description of the experimental animals, housing conditions and dietary composition has been published earlier [8]. Newly weaned male and female Wistar rats, Bor:WISW (SPF Cpb), were obtained from F. Winkelmann, Borche, FRG and assigned to three diet groups. From an age of four weeks, the animals were fed ad. libitum a purified diet containing $250 \mathrm{~g}$ casein and either $0.3 \pm 0.2 \mathrm{mg}(n=55)$, $3.2 \pm 0.1 \mathrm{mg}(n=120)$ or $5.9 \pm 0.9 \mathrm{mg}(n=120)$ vitamin B-6 per kg. Experimental groups were named after the amount of vitamin B-6 present in the diet $(<0.5,3$ and $6 \mathrm{mg} / \mathrm{kg}$, respectively), with the $6 \mathrm{mg} / \mathrm{kg}$ diet being the control group. At the age of 6 months ten male and ten female rats from each diet group were randomly selected from different cages for behavioral testing. At the age of 18 months the same animals were retested.

\section{Testing procedure}

The tests were performed according to the methods described below. The sequence of the various tests is given in Table 1. An attempt was made to subject the animals to the least provoking test first. All testing was done during the light part of the diurnal cycle. After completion of each test all animals were returned to their original cages and cage-mates.

Table 1. Testing procedure.

\begin{tabular}{llll}
\hline Day & Tesi & Sex & Session \\
\hline 1 & General aclivity & $\mathrm{M}+\mathrm{F}$ & \\
2 & Negative geolaxis & $\mathrm{M}+\mathrm{F}$ & \\
3 & Air riglning & $\mathrm{M}+\mathrm{F}$ & \\
4 & Rotarod balancing & $\mathrm{M}+\mathrm{F}$ & 1 \\
5 & Rotarod balancing & $\mathrm{M}+\mathrm{F}$ & 2 \\
8 & Active avoldance & $\mathrm{M}$ & 1 \\
9 & Acrive avoidance & $\mathrm{M}$ & 2 \\
10 & Active awoidance & $\mathrm{M}$ & 3 \\
12 & Auditory starle habituation & $\mathrm{M}$ & \\
15 & Active avoidance & $\mathrm{F}$ & 1 \\
16 & Active awoidance & $\mathrm{F}$ & 2 \\
17 & Active avoidance & $\mathrm{F}$ & 3 \\
19 & Auditory statle habituation & $\mathrm{F}$ & \\
\hline
\end{tabular}


The experimental apparatus consisted of a square plastic cage (botton surface $24 \mathrm{~cm}^{2}$, height $15 \mathrm{~cm}$ ) placed on top of an Animex induction coil activity meter. Before testing of each animal, sensitivity and tuning of the apparatus were checked and adjusted as necessary. After thorough cleaning of the cage the counter was set at zero and the animal tested was placed in the center of the plastic cage. General activity, expressed in apparatus counts per minute, was then measured for a twominute period. During the testing procedure, the animal's range of vision was kept as neutral as possible and disturbing noises were avoided. At the end of the testing period the animal was removed from the test cage. Recorded were counts per minute in the first and in the second minute, total counts, and whether or not the animal had urinated or defecated. In the case of defecation, the number of droppings in the test cage was recorded as well. Mean first-minute count, mean second-minute count, and mean total count per diet group were evaluated by analysis of variance (ANOVA). Numbers of animals defecating or urinating were evaluated by the $\chi^{2}$ test.

\section{Negative geotaxis test}

The animal tested was placed head downwards in the center of a $70^{\circ}$ screen incline. The screen consisted of a $8 \mathrm{~mm}$ wire mesh attached to a frame $45 \mathrm{~cm}$ high and $25 \mathrm{~cm}$ wide. The animal was given a maximum response time of $60 \mathrm{~s}$. During this time, the animal's behavior was scored according to the following categories: score 0 , animal did not turn; score 1 , animal did not turn $180^{\circ}$ but attempted to turn; score 2 , animal turnedl by falling with the front paws clambing to the screen; score 3 , animal turned successfully. In case of score 2 or 3 , the turning time was recorded, as well. The number of animals per score was evaluated by the $\chi^{2}$ test, mean turning time by ANOVA.

\section{Air righting test}

After wetting all four feet with tap water at ambient temperature the animal was kept in supine position ca. $30 \mathrm{~cm}$ above a slightly softened surface (foam rubber) covered with absorbent paper. After about 2 seconds the animal was dropped. Landing on all four feet was scored as successful. In case of a successful air righting, the distance between the front paws and the distance between the hind paws were recorded. Each animal was tested three times. The number of animals per trial that could right successfully was evaluated by the $x^{2}$ test, distances between front paws and between hind paws were evaluated by ANOVA.

\section{Rotarod balancing test}

The apparatus used consisted of a turning rod, with a diameter of $15 \mathrm{~cm}$ and the revolving speed kept constant at $10 \mathrm{rpm}$. At the start of the test the animal was 
placed on the rod with the direction of rotation towards the animal. Balancing time was recorded for a maximum of $60 \mathrm{~s}$. Break-off performance was scored according to the following categories: score $\mathbb{F}$, animal fell off (without turning); score $T$, animal turned and fell off; score $J$, animal jumped off. Each animal was tested twice, $24 \mathrm{~h}$ apart. Mean balancing time per trial was evaluated by ANOVA, the number of animals per score per trial by the $\chi^{2}$ test.

\section{Active avoidance test}

The apparatus used consisted of a perspex shuttle box (length $49 \mathrm{~cm}$, width $22 \mathrm{~cm}$, height $27 \mathrm{~cm}$ ), divided into two equal compartments by a PVC partition with a circular opening of $9 \mathrm{~cm}$ diameter. The box was provided with a grill floor consisting of bars $1 \mathrm{~cm}$ apart. The bars were alternately connected with an $\mathrm{A} / \mathrm{C}$ regulator, such that each compartment could be electrified separately. The box was closed with a perspex lid provided with a light source (two $30 \mathrm{~W}$ light bulbs) that was used as the stimulus. During the test the shuttle box was placed in a light- and soundproof isolation chamber, measuring $100 \mathrm{~cm} \times 52 \mathrm{~cm} \times 60 \mathrm{~cm}$. The isolation chamber was supplied with an ellectric air pump for the provision of fresh air and the generation of a constant, low-volume background noise. Registration of all test resullts was fully automated.

At the start of the experimental procedure the animal was placed in the shuttle box, with the air pump on and light off, after which both the shuttle box and the isolation chamber were closed. The animal was allowed one minute of exploration time, after which the test session of 50 trials was started. The procedure of each trial depended on the animal's behavior as described below. Each animal was tested in three sessions of 50 trials each.

At the start of each trial the light was turned on. If the animal crossed to the other compartment within $6 \mathrm{~s}$ the trial was scored as 'avoidance'. The light was turned off and after $20 \mathrm{~s}$ the next trial was started. If the animal did not cross to the other compartment within $6 \mathrm{~s}$ the light was turned off and immediately after the $6 \mathrm{~s}$ light signal, the floor of the compartment in which the animal was situated at that time was electrified with approximately $0.2 \mathrm{~mA}$. If the animal escaped to the other compartment within another $6 \mathrm{~s}$, the trial was scored as "escape". The current was lurned off and after $20 \mathrm{~s}$ the next trial was started. If the animal did not escape from the electrified compartment to the other one within $6 \mathrm{~s}$, the trial was scored as 'no response'. The current was turned off after $6 \mathrm{~s}$ and $20 \mathrm{~s}$ later the next trial was started.

Total number of scores per category (avoidance, escape, no response) was recorded together with total waiting time. Total waiting time was defined as the time between turning on the light and moving of the animal to the other compartment. Furthermore, it was recorded whether the animal met the test criterion, which was defined as scoring an "avoidance" on at least five successive trials during a test session. Mean number of scores per category and total waiting time per test session 
were evaluated by ANOVA. The number of animals meeting the test criterion was evaluated per test session by the $x^{2}$ test.

\section{Auditory startle test}

The stimulus involved the repeated presentation of a $4000 \mathrm{~Hz}$ tone delivered for $50 \mathrm{~ms}$ at $120 \mathrm{~dB}$ against a $60 \mathrm{~dB}$ background noise level. An $8 \mathrm{~s}$ interval was used between trials and a total of 50 trials were given. The test chamber consisted of a cylindrical perspex cage (bottom surface $20 \mathrm{~cm}^{2}$, height $15 \mathrm{~cm}$ ) with an accelerometer located under the center of the cage base. The accelerometer sensed cage movements through a voltage change. The voltage change was amplified, put through a A-to-D converter and sent to a microprocessor. For each trial the peak voltage output from the accelerometer amplifier during the $100 \mathrm{~ms}$ following the onset of each tone presentation was recorded, together with the delay time between stimulus and maximum amplitude measured. From the 50 data sets per animal parameters of interest were calculated: mean amplitude of 10 successive trials (five times), slope of five 10-trial amplitude means, slope of amplitude of trials 1-10, mean delay time of 10 successive trials (five times) and slope of five 10-trial delay time means. The slope

Table 2. Body weight (BW), feed intake (mean \pm SEM) and survival of male and female Wistar rats at 6 and 18 months of age.

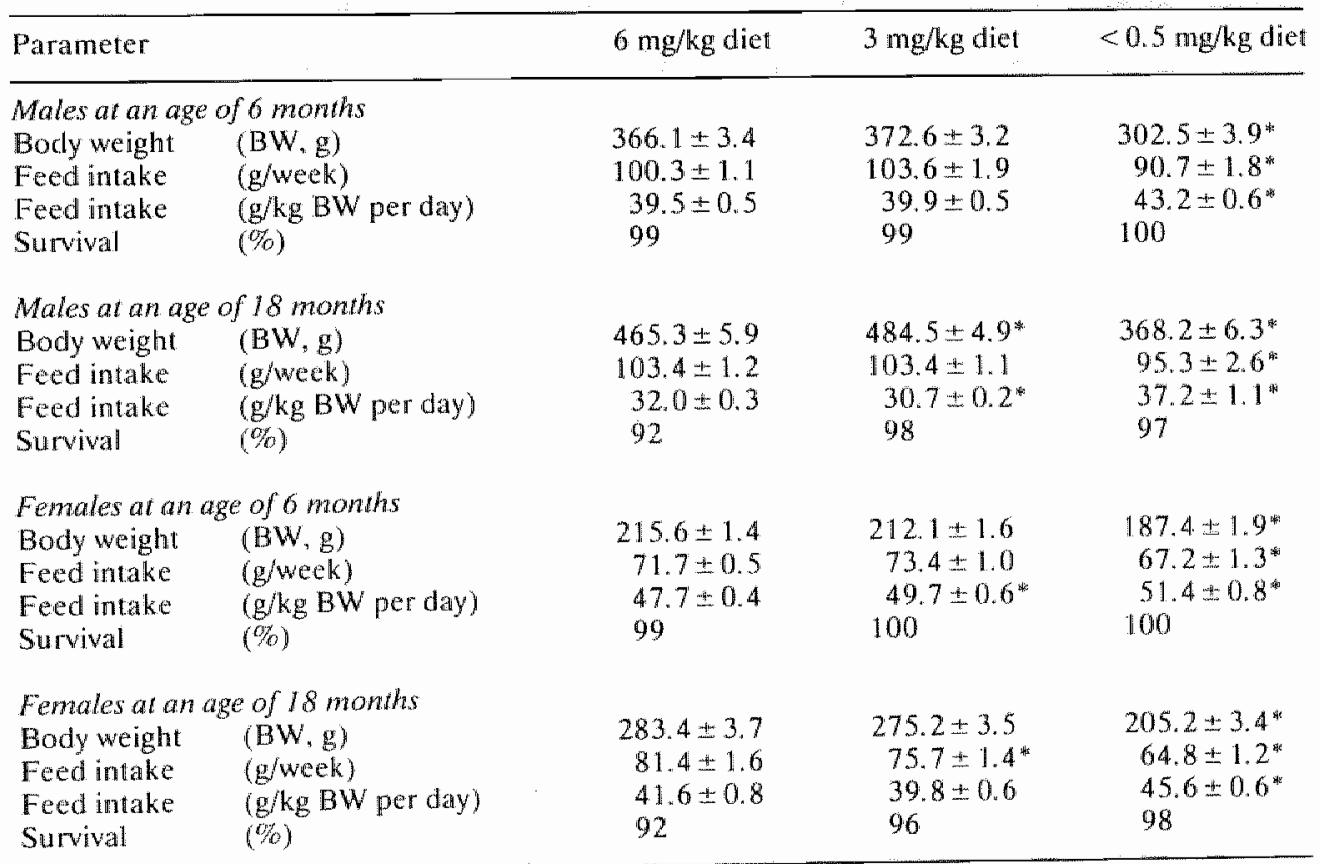

\footnotetext{
* Significantly different from the $6 \mathrm{mg} / \mathrm{kg}$ diet at $P<0.05$ (ANOVA)
} 
of the amplitude of trials 1-10 and the slope of five 10-trial delay time means were evaluated by ANOVA.

\section{Statistical analysis}

All statistical evaluations were performed with the GENSTAT statistical package. A probability level $(P)<0.05$ was considered statistically significant.

\section{Results}

Parameters descriptive of physical growth of the total cohort of rats (from which the animals used in behavioral testing were taken) are summarized in Table 2 . Both male and female rats fed the $<0.5 \mathrm{mg} / \mathrm{kg}$ diet had a lower body weight and lower absolute feed intake than corresponding controls. Feed intake relative to body weight, however, was higher in the $<0.5 \mathrm{mg} / \mathrm{kg}$ diet group than in the controls.

Fig. 1 illustrates general activity scores at the age of 6 and 18 months, respectively, as recorded during the first and the second minute of the trial period. As could be expected, all experimental groups showed lower scores during the second minute of the test due to habituation. Neither activity scores (during the first minute, during the second minute, or total score) nor defecating and urinating behavior differed significantly between diet groups. No apparent age or sex influence on exploratory behavior was observed either.

Results from negative geotaxis testing at 6 and 18 months of age indicated that $\geq 90 \%$ of the animals in all experimental groups turned within the given one-minute

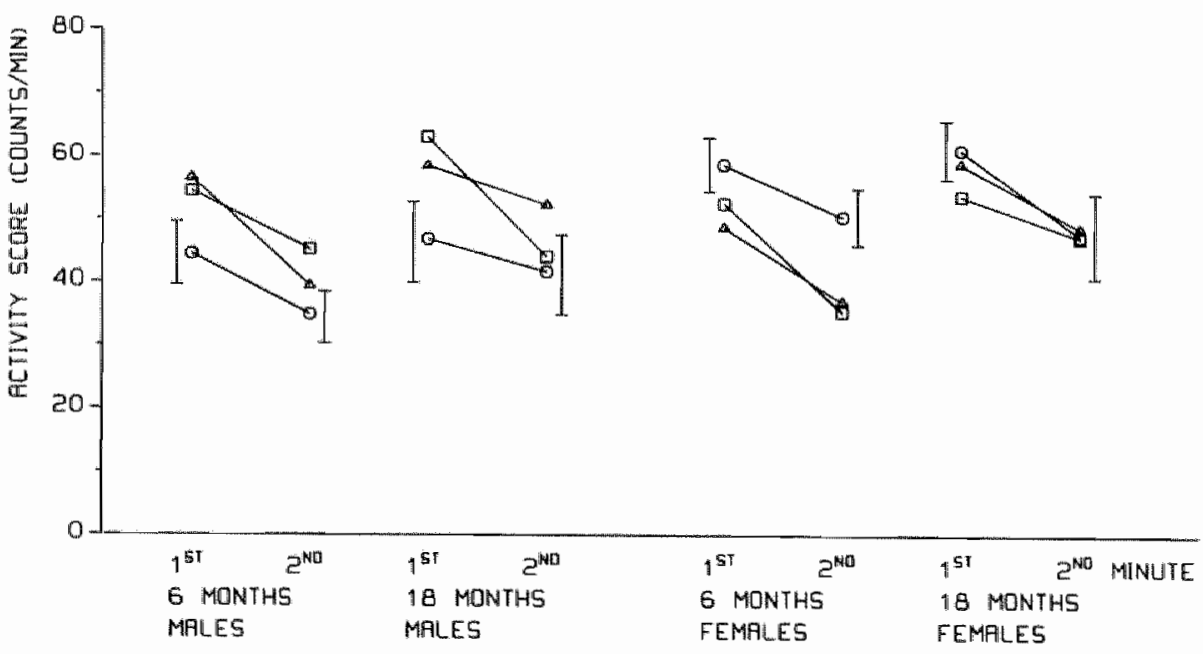

Fig. 1. General activity scores of rats fed the $6 \mathrm{mg} / \mathrm{kg}$ diet (squares), the $3 \mathrm{mg} / \mathrm{kg}$ diet (circles) and the $<0.5 \mathrm{mg} / \mathrm{kg}$ diet (triangles). For clarity sake SEM values are indicated for rats fed the $6 \mathrm{mg} / \mathrm{kg} \mathrm{diet}$ only. 


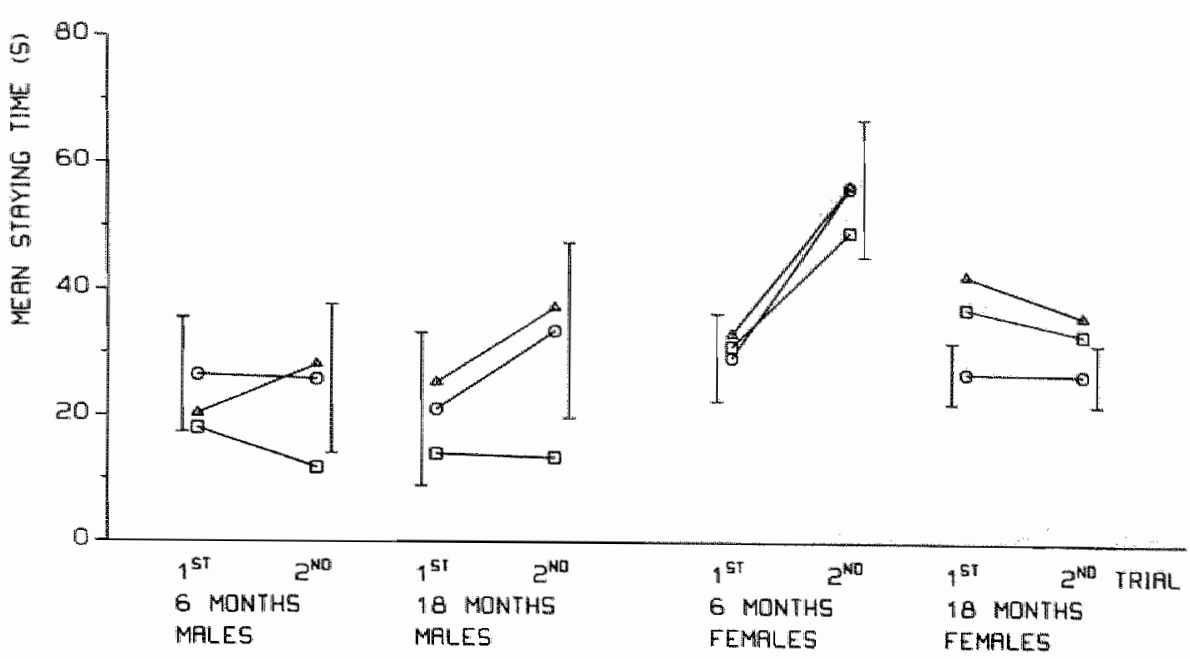

Fig. 2. Rotarod balancing performance (mean staying time) of rats fed the $6 \mathrm{mg} / \mathrm{kg}$ diet (squares), the $3 \mathrm{mg} / \mathrm{kg}$ diet (circles) and the $<0.5 \mathrm{mg} / \mathrm{kg}$ diet (triangles). For clarity sake SEM values are undicated for rats fed the $6 \mathrm{mg} / \mathrm{kg}$ diet only.

response time. Mean turning time was $15-25 \mathrm{~s}$ at both ages and did not differ significantly between experimental groups. However, at the age of 18 months a higher number of animals turned passively, by dropping while clinging the front paws to the screen, than at the age of 6 months $(57 \%$ and $15 \%$, respectively; $P<0.05)$. No sex influence was observed.

Air righting test performance did not differ significantly between diet groups nor between males and females. The percentage of animals that could right in the air tended to decrease with age (from $94 \%$ to $76 \%$, averaged over all trials).

Rotarod test performance is illustrated in Fig. 2. Mean staying time was not significantly influenced by diet. At the age of 6 months female rats showed a longer mean staying time during the second than during the first trial. The percentage of animals that fell off the rod after turning was higher for females than for males ( $32 \%$ versus $4 \%$, averaged over all trials). No further trial-, age- or sex-related differences were observed.

The results for the active avoidance test are shown in Figs. 3 and 4. Mean total waiting time tended to decrease in the three successive sessions in all groups except for males fed the $3 \mathrm{mg} / \mathrm{kg}$ diet at an age of 18 months (Fig. 3). The observed decrease in total waiting time is indicative of the learning ability of the animals. Females at an age of 6 months showed the largest decrease in total waiting time over the three sessions. Total waiting time was always longer for males than for females of the same group. Female rats showed higher 'avoidance' scores and lower 'no response' scores than males of the same group (Fig. 4). The percentage of animals meeting the criterion ( $\geq$ five successive avoidances per session) was higher for females than for males ( $83 \%$ versus $43 \%$ averaged over all trials; $90 \%$ versus $46 \%$ averaged 


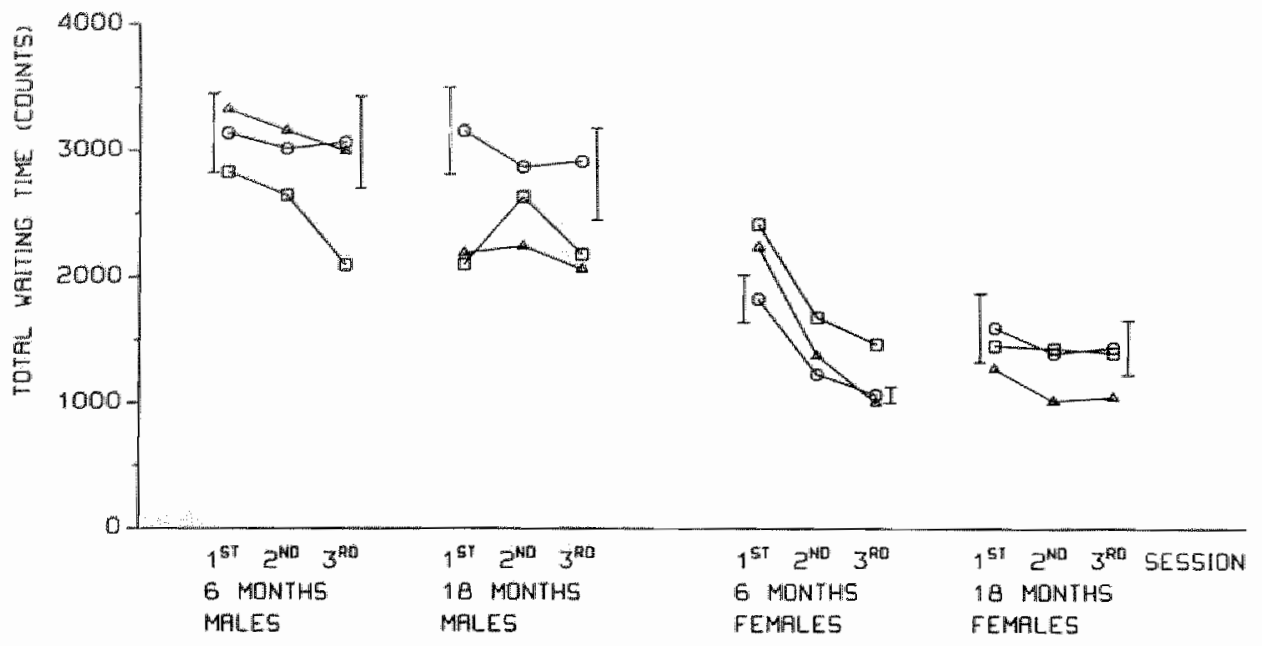

Fig. 3. Active avoidance test performance (total waiting time) of rats fed the $6 \mathrm{mg} / \mathrm{kg}$ diet (squares), the $3 \mathrm{mg} / \mathrm{kg}$ diet (circles) and the < $0.5 \mathrm{mg} / \mathrm{kg}$ diet (triangles). For clarity sake SEM values are indicated for rats fed the $6 \mathrm{mg} / \mathrm{kg}$ diet, in the first and third session, only.

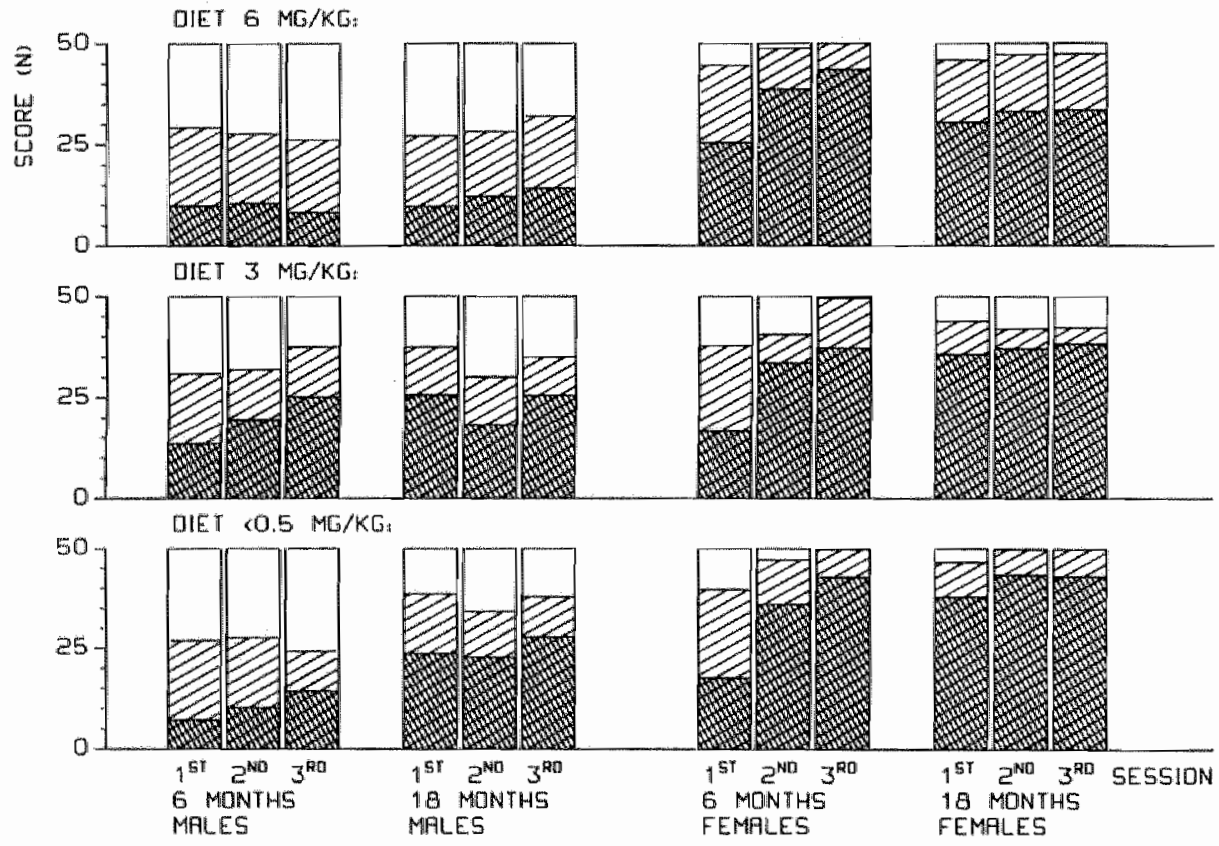

Fig. 4. Active avoidance test scores of rats fed the $6 \mathrm{mg} / \mathrm{kg}$ diet, the $3 \mathrm{mg} / \mathrm{kg}$ diet and the $<0.5 \mathrm{mg} / \mathrm{kg}$ diet. Crossed bar, avoidance; shaded bar, escape; open bar, no response. For darity sake SEM values aredeleted. 


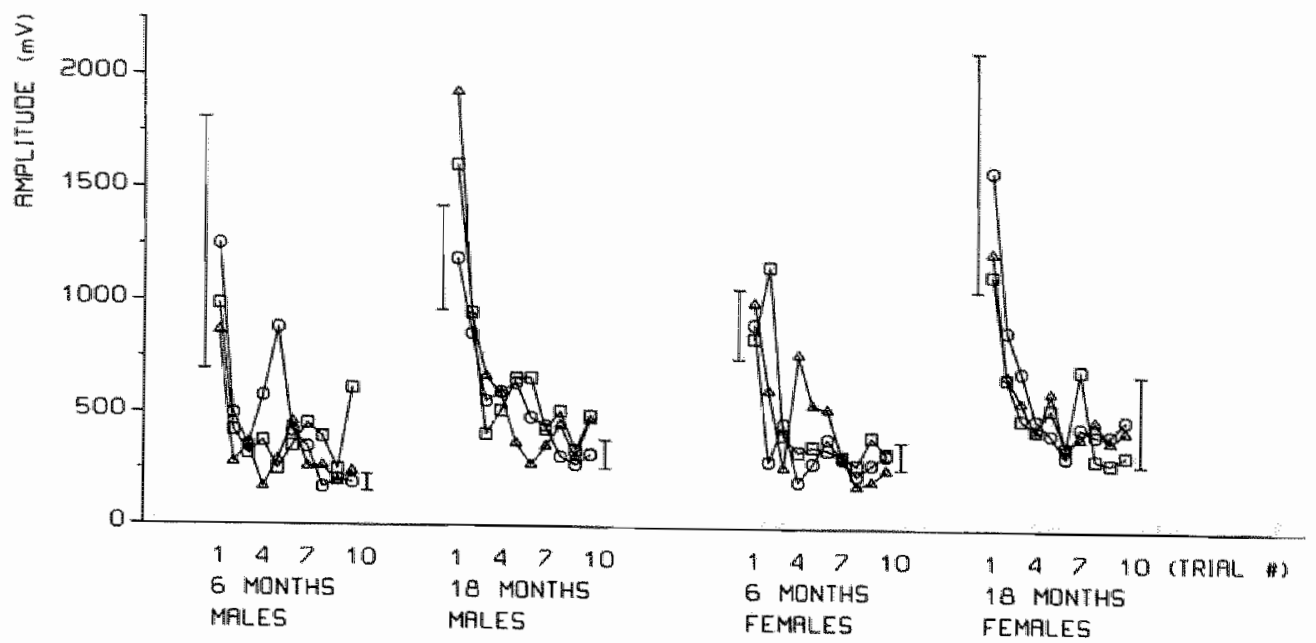

Fig. 5. Amplitude of auditory startle response in trials $1-10$ of rats fed the $6 \mathrm{mg} / \mathrm{kg}$ diet (squares), the $3 \mathrm{mg} / \mathrm{kg}$ diet (circles) and the $<0.5 \mathrm{mg} / \mathrm{kg}$ diet (triangles). For clarity sake SEM values are indicated for rats fed the $6 \mathrm{mg} / \mathrm{kg}$ diet, in the first and tenth trial, only.

over the best trial per experimental group). No significant diet-related difference in performance was observed.

The mean response during trials $1-10$ of the auditory startle test is shown in Fig. 5. The amplitude of response decreased with trial number in all experimental groups. At the age of 18 months mean delay time to maximum amplitude was longer than at the age of 6 months: approximately $50 \mathrm{~ms}$ versus approximately $40 \mathrm{~ms}$. No further diet-, sex- or age-related differences were observed.

\section{Discussion}

The lower vitamin B-6 status, measured as plasma PLP concentration, that is generally observed in elderly people might seem a good reason to increase the vitamin B-6 recommended dietary allowance (RDA) for the aged. However, one should bear in mind the possibility that a lower plasma PLP level in the elderly does not necessarily reflect a functional age-related decrease in vitamin B-6 nutritional status, but rather an age-related change in vitamin B- 6 distribution among various body compartments. Indications for an intrinsic age effect on vitamin B-6 distribution in rats have been reported [9]. The plasma PLP concentration decreased with age in male and female rats fed an adequate amount of vitamin B-6 from weaning until 31 months of age. In the same animals, the vitamin B-6 level in liver, gastrocnemius muscle and kidney tissue showed an age-related decrease, too. However, the vitamin B-6 concentration increased with age in heart and brain tissue. 
Increasing the vitamin B-6 RDA for the elderly should be taken into consideration only when inadequate biochemical vitamin B-6 status parameters in the aged have been proved to be related to impaired functional criteria.

In witamin B-6 deficient humans and animals behavioral abnormalities have been reported. Most reports, however, describe very young (pre-weaning) animals or subjects. As vitamin B-6 is important in brain development, serious behavioral impaiment is to be expected if vitamin B-6 deficiency is induced before nervous tissue development is completed. Adult human data usually consist of reported observations on subjects made vitamin B-6 deficient through drug administration [10 11]. Observations on vitamin B-6 deficiency symptoms induced by dietary manipulation alone in post-weaning or adult animals (or humans) are sparse.

In a study by Sloane \& Chow weanling rats were fed either a vitamin B-6 deficient or control purified diet [12]. The controls were fed ad libitum or pair-fed to the same body weight as deficient rats. The animals were tested at an age of $4-5$ months. The vitamin B-6 deficient rats showed inferior performance in cognitive behavior when compared to both control groups (operant conditioning test). Kantor et al. compared 24-hour general activity of male weanling Wistar rats fed diets containing graded levels of vitamin B-6 [13]. Throughout most of the 3.5-week study period animals on diets containing 0 or $0.5 \mathrm{mg} \mathrm{PN} \cdot \mathrm{HCl}$ per $\mathrm{kg}$ were less active than animals on diets containing 1 or $6 \mathrm{mg} \mathrm{PN} \cdot \mathrm{HCl}$ per kg. Similar results were obtained earlier, with a smaller number of animals, by Hoff et al. [1.4]. Greeley \& Gniecko evaluated shortterm taste behavior in male Long-Evans rats fed a diet deficient in copper and/or vitamin B-6 from weaning until approximately 3 months of age [15]. Vitamin B-6 depleted rats exhibited an elevated taste stimulus water intake. Brosvic \& Hecht tested taste sensitivity in young adult male Long-Evans tats kept on a vitamin B-6 deficient diet from approximately 3 to 4.5 months of age, with or without $\mathrm{PN} \cdot \mathrm{HCl}$ supplementation through their daily water supply [16]. Although the vitamin B-6 deficient rats exhibited and increased $\mathrm{NaCl}$ need, neither sensitivity nor responsiveness to $\mathrm{NaCl}$ was altered.

Schaeffer et al. evaluated motor and sensory function in female Long-Evans rats fed a vitamin B-6 deficient purified diet from the age of 3 months $[17,18]$. During the first ten weeks on the experimental diet inverted whole-body pull-up, landing food spread, hind limb gait, fore and hind limb grip strength, and tail-flick response to immersion in hot water $\left(50^{\circ} \mathrm{C}\right)$ were tested weekly. Performance of vitamin B-6 deficient animals was compared to (pair-fed and ad libitum fed) controls [17]. In week 17 their response to both acoustic and tactile startle stimuli was evaluated [18]. In the deficient animals a significant diet effect was observed for hind limb gait (smaller angle and width of strides) and for amplitude of response to both acoustic and tactile startle stimuli (depressed amplitude of response). In another study by Schaeffer et al. hind leg gait analysis was performed on male Fischer 344 rats fed a vitamin B-6 deficient diet from the age 23 months [19]. Again, vitamin B-6 deficiency reduced width of steps compared to (pair-fed) controls, but in these older animals the angle of steps was not significantly different between diet groups. 
We were interested in evaluating learning behavior in relation to long-term dietinduced graded vitamin B-6 cleficiency in rats. Scores in the animal's cognitive behavior tests may very well be influenced by sensory and/or motor function. impairment or changes in "emotionality/motivation" of the animals tested, as a result of dietary deprivation. Such behavioral scores need not reflect a difference in learning ability per se. To exclude possible interferences, several functional tests were included in the experiment as well.

Reflexes were tested in the air righting test. Performance, i.e. percentage of animals that could right, did not differ among sex and diets groups, with the older animals showing a tendency towards a poorer performance. Despite large differences in body size (Table 2), the spread of front and hind paws did not differ among experimental groups. Sensory and motor function were evaluated in the negative geotaxis and rotarod balancing tests. Rats fed the $<0.5 \mathrm{mg} / \mathrm{kg}$ or the $3 \mathrm{mg} / \mathrm{kg}$ diets did not show a functional impairment compared to corresponding controls. An agerelated difference in turning behavior was observed in the negative geotaxis test. At 18 months of age more animals turned passively by dropping the body while clinging to the screen, instead of actively turning by climbing on all four paws, which was more frequently seen at 6 months of age. This might indicate a slight decrease in motor function with age. The observation in the rotarod test that more female than malle rats turned around on the rotating rod and, as a consequence, fell off, is probably related to the smaller body size of the female rats: moving space on the turning rod was comparatively small for the bigger male rats, thus preventing an easy turn. The longer mean staying time for the young female rats (during the second trial) than for the same animals at old age or for male rats of the same age indicates a higher locomotor skill and a faster learning ability (Fig. 2). In the general activity test, however, no age- or sex-related difference in general activity score was observed (Fig. 1). Besides locomotor activity, results from the general activity test mainly provide information about the motivational status and emotionality of the animal. No diet-, sex- or age-related differences were observed.

The auditory startle test was used to evaluate non-associative learning. Furthermore, the amplitude of the response to the auditory stimulus is also indicative of sensory and motor function. Contrary to the findings of Schaeffer [18] no difference for this parameter was observed beiween diet groups (Fig. 5). A decrease of response amplitude in time indicates habituation to the auditory stimulus. All experimental groups showed similar attenuation of the startle response. The longer delay time between stimulus and maximum response observed for the older than for the younger rats might indicate a slight age-related impairment of nerve conductivity, resulting in delayed neurological response.

Associative learning was evaluated in the active avoidance test. Females performed better than males in all experimental groups, showing shorter mean total waiting time (Fig. 3), higher avoidance scores (Fig. 4), and a higher percentage of animals meeting the test criterion (five successive avoidances). The lower mean total waiting time in female rats during the first session at the age of 18 months compared to that observed at the age of 6 months is considered a fortuitous finding rather than 
a consequence of the fact that the animals at the age of 18 months were not experimentally naive. As 12 months passed between these test sessions, possible conditioning most probably was extinguished completely. Better performance (i.e. shorter total waiting time) of females than of males is a generally observed phenomenon in this test.

Although the tests performed here were sensitive enough to show some age-or sexrelated differences in behavior, no significant diet-related effect was observed in any test. In animals obtained from the same cohort the B-6 vitamer content of various body compartments has been assessed (unpublished observations). At an age of 13 months the plasma PLP concentration of rats fed the $<0.5 \mathrm{mg} / \mathrm{kg}$ diet was below $10 \%$ of the plasma PLP level in corresponding controls. At an age of 25 months the $<0.5 \mathrm{mg} / \mathrm{kg}$ diet rats showed plasma PLP levels below $5 \%$ of control values. Muscle and brain PLP concentration differed less between the $<0.5 \mathrm{mg} / \mathrm{kg}$ and $6 \mathrm{mg} / \mathrm{kg}$ diets than plasma PLP levels. At an age of 13 months the muscle PLP concentration of animals fed the $<0.5 \mathrm{mg} / \mathrm{kg}$ diet was $40-55 \%$ of corresponding control, whereas at an age of 25 months this was $35-40 \%$. For brain PLP level, these percentages were $65-75$ at 13 months of age and $45-50$ at 25 months of age. Tissue levels of rats fed the $3 \mathrm{mg} / \mathrm{kg}$ diet were not significantly different from tissue levels of control rats. Plasma PLP levels indicated that the animals fed the $<0.5 \mathrm{mg} / \mathrm{kg}$ diet indeed were biochemically vitamin B-6 deficient. However, in muscle organ tissue biochemical vitamin B-6 deficiency was less outspoken. Furthermore, the brain vitamin B-6 content seemed less affected by long-term low dietary vitamin B-6 intake than was muscle vitamin B-6 content. If biochemical tissue vitamin B-6 deficiency is correlated with functional impairment, apparently brain function is relatively spared the detrimental influences of low dietary vitamin B-6 intake.

\section{References}

1. Rose CS, György P, Butler M. Andres R, Norris AH, Shock NW, Tobin J, Brin M, Spiegel H. Age differences in vitamin B-6 status of 617 men. Am J Clin Nutr 1976:29: 847-53.

2. Löwik MRH, van den Berg H, Westenbrink S, Wedel M, Schrijver J, Ockhuizen Th. Doseresponse relationships regarding vitamin B-6 in elderly people: a nationwide nutritional survey (Dutch Nutritional Surveillance System). Am J Clin Nutr 1989;50:391-9.

3. Hamfelt A, Söderhjelm L. Vilamin B-6 and aging. In: Leklem JE, Reynolds RD, Eds. Clinical and physiological applications of witamin B-6. New York: Alan R. Liss, 1988: 95-107. (Current topics in nutrition and disease Vol. 19.)

4. Garry PJ, Goodwin JS, Hunt WC, Hooper EM, Leonard AG. Nutritional status in a healthy elderly population: dietary and supplemental intakes. Am J Clin Nutr 1982;36: 319-31.

5. Guilland JC, Bereksi-Reguig B, Lequeu B, Moreau D, Klepping J, Richard D. Evaluation of pyridoxine intake and pyridoxine status among aged institutionalised people. Internat $J$ Vit Nutr Res 1984;54: 185-93.

6. Löwik MRH, Westenbrink S, Hulshof KFAM, Kistemake ' C. Hermus RJJ. Nutrition and aging: dietary intake of 'apparently healthy' elderly (Dutch Nutrition Surveillance System), J Am Coll Nutr 1989:8: 347-56.

7. Dakshinamurti K. Paulose CS, Viswanathan M, Siow YL, Sharma SK. Neurobiology of pyridoxine. Ann N Y Acad Sci 1990;585: 128-44.

8. Bodle W, van den Berg H. Pyridoxal-5'-phosphate and pyridoxal biokinetics in male Wistar rats fed graded levels of vitamin B-6. J Nutr 1991:121: 1838-45. 
9. Bode W, Macking JAJ, van den Berg 4 . Influence of age and sex on witamin B-6 witamer distribution and on vitamin B-6 metabolizing enzymes in Wistar rats. J Nutr 1991:121:318-29.

10. Vilter RW, Mweller JF, Glazer HS, Jarrold T, Abraham J, Thompson C. Hawkins VR. The effect of vitamin B-6 deficiency induced by desoxypyridoxine in human beings. $\mathrm{J}$ Lab Clin Chem $1953 ; 42: 335-57$.

11. Kalinowski SZ, Lloyd TW, Moyes EN. Complications in the chemotherapy of tuberculosis: a review with analysis of 3148 patients. Ann Rev Respir Dis 1961;83: 359-71.

12. Sloane Ir HN, Chow BF. Vitamin B-6 deficiency and the initial acquisition of behavion. $J$ Nutr 1964:83: 379-84.

13. Kantor MA. Trout JR, Lachance PA. Locomotor activity of rats housed in novel activity cages: effects of vitamin B-6 and temperature. Nutr Res 1985;5:381-91.

14. Hoff LA, Peacock LJ, Meadows JS, Caster WO. The vitamin B-6 requirement of the rat as estimated with weight gain and general activity measurements. Physiol Behav 1968:3: 301-3.

15. Greeley S, Gniecko K. Short-term taste behavior and copper/vitamin B-6 nutriture in LongEvans rats. Physiol Behav 1986;38: 765-71.

16. Brosvic GM, Hecht GS. Effects of copper and vitamin B 6 deficiency on taste sensitivity in the rat: a signal detection analysis. Physiol Behav 1989;45: 1139.46.

17. Schaeffer MC, Kretsch MJ. Quantitative assessment of motor and sensory function in vitamin B-6 deficient rats. Nutr Res 1987:7:851-63.

18. Schaeffer MC. Attenuation of acoustic and tactile startle responses of vitamin B-6 deficient rats. Physiol Behav 1987;40:473-8.

19. Schaeffer MC, Cochary EF, Sadowski JA. Subtle abnormalities of gait detected carly in vitamin B-6 deficiency in aged and weanling rats with hind leg gait analysis. $J$ Am Coll Nutr 1990;9: $120-7$. 

Part V. Conclusion 



\section{General discussion}

\section{Experimental design}

The aims of the project 'vitamin B-6 and aging' were to elucidate the mechanism behind the well documented, age-related decrease in plasma pyridoxal-5'-phosphate (PLP) concentration, and to study the functional consequences of a long-term low or marginal vitamin B-6 status. In order to reach these goals animal studies were preferred to experiments with human volunteers, because in this way processes in compartments such as plasma and erythrocytes could be studied in correlation to those in compartments not readily accessible in man, such as liver and muscle tissue. A variety of studies were performed on experimental animals obtained from a cohort of aging rats. A major drawback of this experimental setup is that all experiments on old animals had to be performed at roughly the same time. It was not possible to further explore interesting findings because additional studies could not be included. Obtaining more old animals would mean starting a new rat cohort study after finishing the studies described in this thesis, the results of which would not be available until at least 2.5 years later. The main advantages of performing an inhouse rat cohort study are that the experiments were not cross-sectional but (semi) longitudinal, and that the animals studied were maintained under strictly controlled conditions from weaning until old age, especially regarding vitamin B-6 intake.

\section{Experimental animals}

In aging research interpretation of findings is complicated by the increased prevalence of pathological processes at higher age. In our studies on the relation between vitamin B-6 and aging in rats (interference of) pathology was excluded as much as possible. The animals selected for the various experiments were without macroscopic and microscopic lesions and had clinical chemistry parameters within reference ranges. As a result, especially the old experimental animals were not representative of the total cohort from which the rats were obtained (described in Chapter 4), but of the average healthy old rat in the cohort. When results are interpreted and relevance to the human situation is discussed, this should be kept in mind. 
Basic findings on vitamin B-6 and aging are presented in Chapters 5 and 6 . In Chapter 5, Wistar rats at various ages fed a diet containing adequate levels of all nutrients (including vitamin B-6) are thouroughly characterized with respect to vitamin B-6 status, vitamin B-6 body distribution, and in vitro activities of vitamin B-6 metabolizing enzymes. In Chapter 6 similar data are presented for another strain of rats, Brown-Norway. Findings of the Wistar rat study could be substantiated this way. To facilitate interpretations of results on the aging Wistar and Brown-Norway rats, the influence of a long-term low vitamin B-6 intake on the same set of biochemical parameters was assessed as well (Chapter 10).

Results from the descriptive in vitro experiments presented in Chapters 5 and 6 were independently verified by using a biokinetic (dynamic) instead of a biochemical (static) approach. Short-term in vivo biokinetic processes (plasma PLP clearance and appearance) of young and old rats are compared in Chapter 7 . Results of this shortterm vitamin B-6 biokinetics study were verified in the in vitro liver perfusion experiments described in Chapter 8 . For a better insight similar experiments were performed on animals with a low to marginal vitamin B-6 status; results are presented in Chapter 11. Long-term in vivo biokinetic processes (tissue and total body retention of vitamin B-6) are described in Chapter 9.

Functional consequences of a long-term (life-long) low to marginal vitamin B-6 status are described in Chapter 4 (mortality, morbidity, body weight gain, feed intake), Chapter 10 (clinico-chemical parameters, vitamin B-6- dependent enzymes, immunological functioning), and Chapter 12 (behavior).

\section{What makes plasma PLP decrease with age?}

In the healthy Wistar rats fed a vitamin B-6 adequate diet throughout their life an agerelated decrease in plasma PLP was observed (Chapter 5), similar to observations in human population studies (Chapter 2). This lower plasma PLP concentration with increasing age could be explained by various mechanisms, alone or in combination:

1. lower vitamin B-6 intake,

2. Iess efficient absorption of vitamin B-6 consumed (lower vitamin B-6 bioavailability),

3. increased plasma PLP clearance,

4. decreased plasma PLP formation,

5. changed vitamin B-6 body distribution at the expense of plasma,

6. increased vitamin B-6 body turnover. 
Vitamin B-6 intake was known for the Wistar rats only. For Brown-Norway rats feed intake data were available, but only for similar animals kept under the same conditions. In our experimental Wistar rats feed intake and hence vitamin B-6 intake was fairly constant over the animal's entire life-span (Chapter 5). It is concluded that in our experimental animals lower plasma PLP levels can not be attributed to a lower vitamin $\mathrm{B}-6$ intake at higher age.

\section{Vitamin B-6 absorption}

In the experimental diets fed to Wistar rats vitamin $\mathrm{B}-6$ was present as pyridoxine $\cdot \mathrm{HCl}(\mathrm{PN} \cdot \mathrm{HCl})$. In an experiment with ${ }^{14} \mathrm{C}$-labeled $\mathrm{PN} \cdot \mathrm{HCl}$ the extent of absorption of ${ }^{14} \mathrm{C}$ label after an oral dose of $\left[{ }^{14} \mathrm{C}\right] \mathrm{PN}$ " $\mathrm{HCl}$ was close to $100 \%$ in both young and old rats, examined at the age of 6 and 31 months, respectively (Chapter 9). Apparently, absorption of vitamin B-6 was not lower at higher age. When extrapolating this finding to man, the possible difference in vitamin B-6 bioavailability between the experimental, purified rat diet and foodstuffs consumed by man should be taken into account. In the average human diet vitamin B-6 is not only present as PN, but also as PLP and (less) pyridoxamine-5'-phosphate (PMP). These phosphorylated B-6 vitamers are absorbed after hydrolysis to the corresponding nonphosphorylated forms (Chapter 2). PLP and PMP in food are predominantly bound to proteins. This protein binding inhibits intraluminal hydrolysis. At low intraluminal $\mathrm{pH}$ protein binding of PLP, thought to occur via Schiff base formation [1], is decreased. In the elderly achlorhydria and the use of gastric-acid-lowering drugs are more prevalent than in young adults. Theoretically, a higher postprandial gastric and upper small intestinal $\mathrm{pH}$ may result in lower PLP absorption due to inhibited intraluminal dephosphorylation. However, the vitamin B-6 status of elderly people is reported not to be influenced by severe atrophic gastritis [2]. Results from our rat experiments indicate that absorption of unphosphorylated PN is not impaired at higher age. Observations by others suggest that an age-related decrease in absorption of phosphorylated B-6 vitamers present in the human diet is unlikely to occur in man.

\section{Plasma PLP clearance and plasma PLP formation}

An inverse correlation has been observed between plasma PLP concentration and serum alkaline phosphatase (AP) activity [3]. AP dephosphorylates substrate PLP to pyridoxal (PL). The observed age-related increase in serum AP activity [4] suggests a causal relationship with the concomitantly observed age-related decrease in plasma PLP level. We assessed disappearance of plasma PLP after i.v. dosing in vivo in intact rats (Chapter 7). Plasma PLP clearance was observed to be similar in young and old animals. In the same study plasma PLP formation after dosing of PL was found to be similar for both age groups. The design of this biokinetic experiment apparently was 
adequate for the study purpose because in a similar experiment on animals with varying vitamin B-6 status differences in both plasma PLP clearance and plasma PLP formation were observed (Chapter 11). In this latter experiment PLP clearance decreased and PLP formation increased, corresponding with a shift towards lower vitamin B-6 turnover with lower vitamin B-6 status. The finding that plasma PLP formation in vivo was not influenced by age was confirmed by the in vitro liver perfusion study (Chapter 6). PLP release into perfusate after a PL dose did not differ between young and old animals. Neither increased plasma PLP clearance nor decreased plasma PLP formation appear to be causally related to the lower plasma PLP level with higher age.

\section{Vitamin B-6 body distribution}

The age-related decrease in plasma PLP concentration observed in Wistar rats fed a vitamin B-6 adequate diet from weaning did not reflect changes in all body tissues (Chapter 5). Some organ tissues also showed an age-related decrease in vitamin B-6 content (gastrocnemius muscle, kidney), but the decrease in vitamin B-6 level started at different ages. For plasma, PLP concentration decreased markedly at younger age (between 7 and 13 months of age), was fairly constant in mid-life (up to 25 months of age), and showed a further decrease at old age (between 25 and 31 months). Vitamin B-6 content of kidney tissue did not change significantly up to an age of 18 months and showed a gradual decrease thereafter. Gastrocnemius muscle vitamin B-6 content first increased, followed by a gradual decrease from the age of 13 months. Other tissues (heart, brain) showed a smaller or larger age-related increase in vitamin B-6 content. Results for Brown-Norway rats showed a similar trend, albeit not all the organ tissues involved followed the same pattern (Chapter 6). An age-related decrease in vitamin B-6 content was observed for Brown-Norway gastrocnemius muscle, brain and kidney, but an increase for heart and liver. In contrast, in Wistar rats with low vitamin B-6 status through dietary manipulation, vitamin B-6 content decreased to some extent in all tissues examined (Chapter 10). The age-related changes in vitamin B-6 level in plasma and tissues of Wistar and Brown-Norway rats were not consistently correlated with changes in vitamin B-6 metabolizing enzyme activities measured in vitro. In animals with a diet-induced low vitamin B-6 status activities of vitamin B-6 metabolizing enzymes measured in vitro did not suggest a shift towards lower vitamin B-6 turnover (Chapter 10). However, enzyme activities measured in vitro may not be an accurate representation of the situation in vivo. An age-related redistribution of body vitamin B-6 at the expense of (among other compartments) plasma appears to be a plausible explanation of the observed decrease in plasma PLP concentration.

\section{Vitamin B-6 body turnover}

In the experiment with ${ }^{14} \mathrm{C}$-labeled $\mathrm{PN} \cdot \mathrm{HCl}$ (Chapter 9) excretion of ${ }^{14} \mathrm{C}$ label into urine and feces was higher in the older animals than in the young ones. However, 
fractional vitamin B-6 turnover rate, calculated from urinary 4-PA specific activity data, was not significantly different between young and old rats. Calculation of the fractional turnover rate from specific activity leans heavily on one assumption: urinary 4-PA specific activity is representative of specific activity of the central vitamin B-6 compartment (the biokinetic body compariment from which vitamin B-6 is excreted into urine). 4-PA specific acitivity was not similar to the specific activities of B-6 vitamers present in gastrocnemius muscle and liver. Although it is possible that neither liver not gastrocnemius muscle are part of the central compartment, the assumption that 4-PA specific activity is representative of total central compartment specific activity may be incorrect. The biokinetic model used was validated by comparing the model-predicted vitamin B-6 content with the value obtained via biochemical vitamin B-6 measurements. The total body vitamin B-6 values predicted by the model and the values actually measured agreed well.

\section{4-PA formation}

In our female Wistar rats an increase in urinary 4-PA excretion, corrected for individual vitamin B-6 intake, was observed at higher age (Chapter 5). In corresponding male rats urinary 4-PA excretion was significantly different among age groups, but no apparent trend was observed. In mammals 4-PA is the main vitamin B- 6 catabolic product excreted into urine. 4-PA is devoid of vitamin B-6 activity. Formation of 4-PA through oxidation of PL is irreversible, so PL oxidation to 4-PA makes active vitamin B-6 get lost to the body. In rats two enzymes have been described to be involved in this process: aldehyde oxidase (EC 1.2.3.1) and NAD-dependent dehydrogenase (EC 1.2.1.4) [5]. In human liver biopsy samples PL-oxidase activity was observed, but PL-dehydrogenase activity was not demonstrated [6].

The age-related increase of 4-PA excretion in female Wistar rats might be explained by a higher flux through the (liver) PL-oxidase and PL-dehydrogenase pathway. This could be the result of the concomitantly observed increase in liver PL-oxidase and PL-dehydrogenase activity measured in vitro (Chapter 5). In female rats a correlation was observed between liver PL-oxidase activity measured in vitro and 4-PA excretion relative to vitamin B-6 intake $(P<0.001$, Fig. 1). This correlation is still significant $(P<0.001)$ after correction for age. In male rats, no significant correlation is observed. For liver PL-dehydrogenase activity results are similar to those for liver PL-oxidase (not shown).

An explanation for higher urinary 4-PA excretion with increasing age other than higher enzyme activity is an increased flux through the pathway as a result of increased substrate availability. Substrate PL availability is regulated by protein binding of PLP. Protein-bound PLP is protected from hydrolysis by alkaline phosphatase, only free (unbound) PLP being dephosphorylated to PL [7]. When PLP protein-binding capacity decreases, the free PLP concentration increases, resulting in a higher PL concentration. Two enzymes compete for substrate 


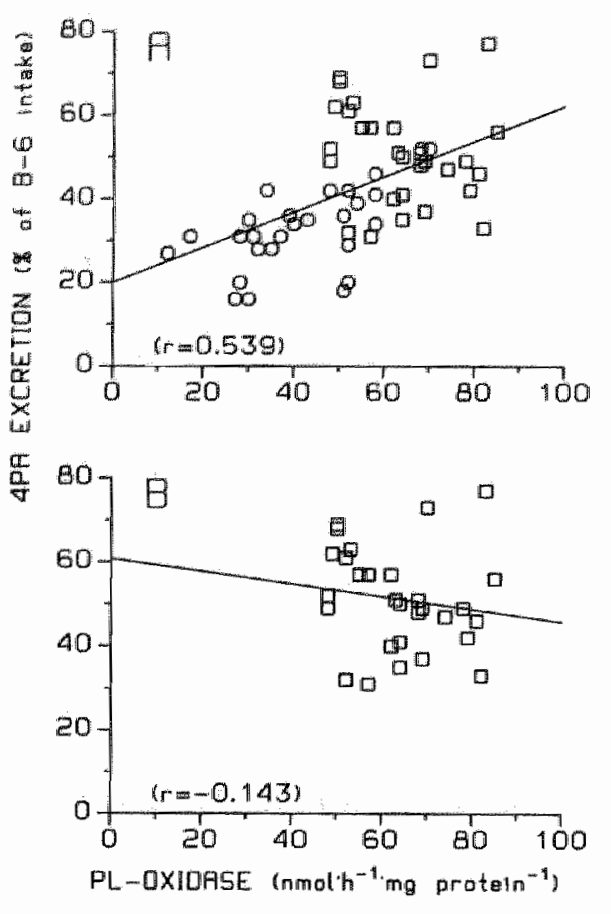

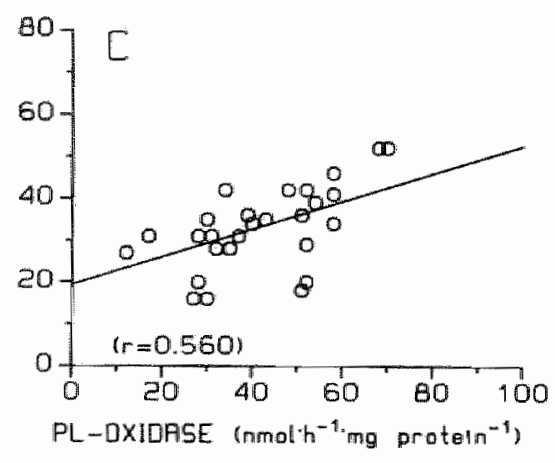

Fig. 1. Correllation between urinary 4-PA excretion (relative to dietary vitamin B-6 intake) and liver PL-oxidase activity of Wistar rats fed a diet containing $6 \mathrm{mg}$ PN.HCl/kg. Squares, males; circles, females. Significance of correlation. $\mathrm{A}$, all animals, $P<0,001 ; \mathrm{B}$, malle rats only, not significant; $C$, female rats only, $P<0.001$.

PL: PL-oxidase (plus PL-dehydrogenase), resulting in oxidation of PL to 4-PA, and PL-kinase (EC 2.7.1.35), resulting in phosphorylation of PL to PLP. In physiological conditions PL-kinase and PL-oxidase have similar $K_{m}$ values for PL [6], but $V_{\text {max }}$ is much higher for PL-oxidase than for PL-kinase, which is illustrated by the difference in enzyme activities measured in vitro at near-physiological $\mathrm{pH}$ (Chapter 5). At physiological pH, 7.2-7.4, PL-dehydrogenase activity in vitio is low or absent. 4-PA formation is expected to increase more than PLP formation if substrate PL concentration increases. This was actually demonstrated in the in vitro liver perfusion experiment (Chapter 8). With higher PL concentration (after a higher PL dose) 4-PA release into perfusate increased more than proportionally with dose, whereas PLP release was lower than expected.

The higher urinary 4-PA excretion observed in old (female) Wistar rats is not considered indicative of a higher vitamin B-6 requirement. Diet-induced vitamin B-6 deficiency does not only lead to a decreased urinary 4-PA excretion (which can be ascribed to lower vitamin B-6 intake) but also to decreased PL-oxidase and PL-dehydrogenase activities measured in vitro in liver homogenates (Chapter 10). Apparently, a shift towards an overall lower vitamin B-6 catabolism is a consequence of vitamin B-6 deficiency. 


\section{Vitamin B-6 redistribution}

Redistribution of body vitamin B-6 appears to be the more likely explanation for the observed age-related decrease in plasma PLP concentration. Age-related redistribution of vitamin $B-6$ is suggested to be related to changes in protein-binding capacity of the various tissues examined (Chapter 5). Protein binding protects PLP against rapid hydrolysis to PL mediated by alkaline phosphatase [7]. In plasma, PLP is predominantly bound to albumin [8]. Plasma albumin concentration decreases significantly with age in Wistar rats, but this decrease is relatively small compared to the observed decrease in plasma PLP level (Chapter 5). Furthermore, even at the lower plasma albumin concentrations observed in old animals albumin-binding capacity exceeds plasma PLP levels observed by far [7]. In Brown-Nonway rats plasma albumin levels were similar in the youngest and oldest age groups with higher values in between, whereas plasma PLP level showed an age-related decrease similar to that observed in Wistar rats (Chapter 6). In organ tissues PLP and PMP, the predominant B-6 vitamers present, are mainly bound to a large variety of vitamin B-6 dependent enzymes. Possibly low affinity binding to other proteins present at high concentrations, such as albumin (in liver) and hemoglobin (in erythrocytes), is relevant in some tissues as well. Because many different enzymes are involved, research into the relation between protein binding and vitamin B-6 level is complicated.

With respect to protein binding of PLP, the striated muscle is a special case. A major amount of vitamin B-6 present in striated muscle tissue is bound to a single enzyme, glycogen phosphorylase (GP, EC 2.4.1.1): 60\% in rats, $75-96 \%$ in mice [9]. Regulation of muscle PLP level and muscle GP activity has still not been completely elucidated yet. In experimental animals excess vitamin B-6 intake (ten times the RDA) results in an increase of both PLP content and GP activity [10, 11]. However, evidence was obtained that muscle PLP is not mobilized by deficient vitamin B-6 intake alone $[11,12]$. Starvation, either induced by reduced feed intake or by prolonged reduced vitamin B-6 intake causing weight loss, results in decreased activity of muscle GP. In accordance with these earlier findings, in our experimental animals fed a diet low in vitamin B-6 from weaning, body weight, gastrocnemius muscle PLP level and gastrocnemius muscle GP activity are lower than values observed in animals fed the control diet (Chapter 10).

In both Wistar and Brown-Norway rats (Chapters 5 and 6 , respectively) both average gastrocnemius muscle PLP level and average gastrocnemius muscle GP activity showed similar age-related trends: an initial increase followed by a decrease with age. In order to further investigate the relation between GP activity and PLP level we calculated the correlation between these two parameters in individual animals (instead of group averages). Besides data on the Wistar and Brown-Norway rats presented in Chapters 5 and 6 , data from Wistar rats fed diets with a lower vitamin B-6 level (Chapter 10) were examined. Results are summarized in Fig. 2. The correlation is significant in all experimental groups, but differences in slopes and 

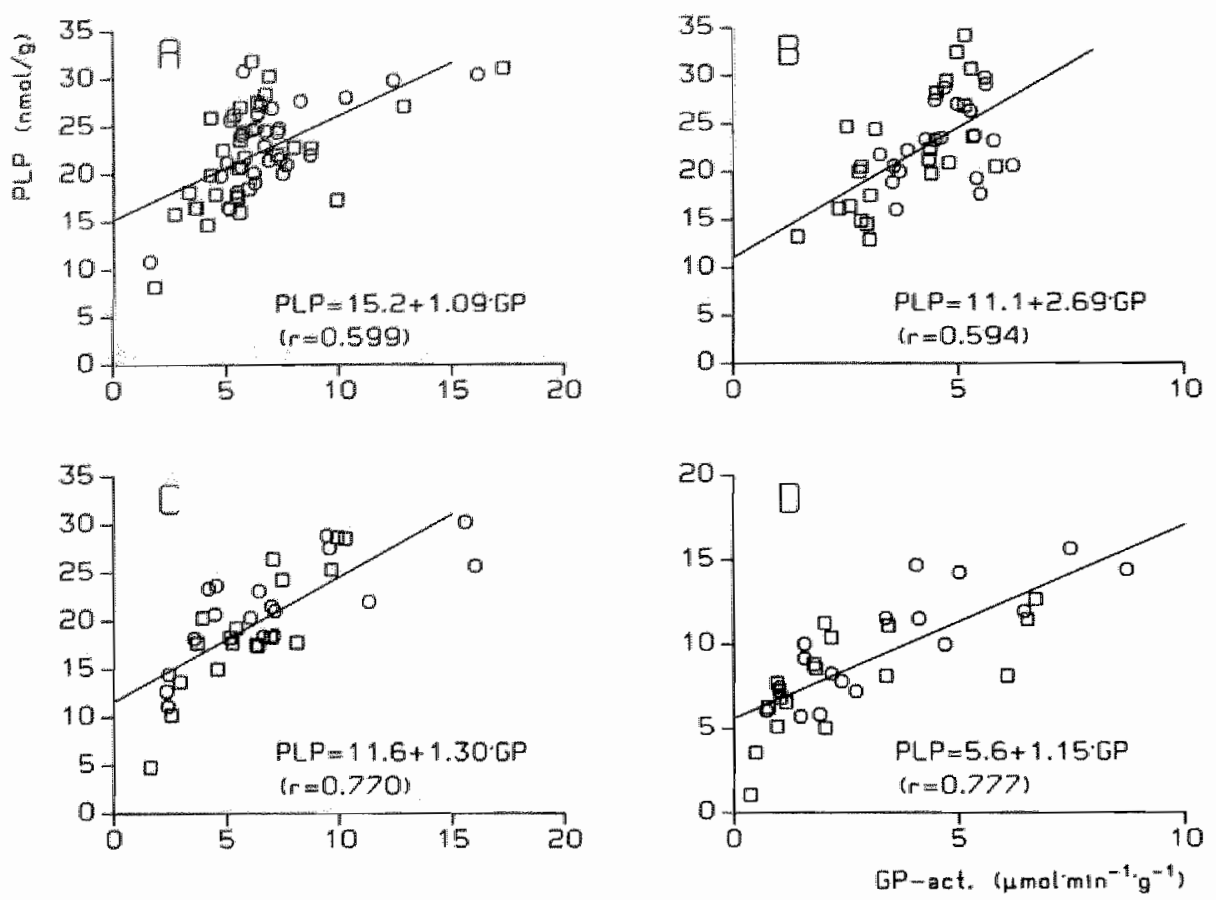

Fig. 2. Contelation between gastrocnemius muscle PLP concentration and gastrocnemius muscle GP activity. A, Wistar rats, diet $6 \mathrm{mg} \mathrm{PN} \cdot \mathrm{HCl} / \mathrm{kg}$ (significant at $\mathrm{P}<0.001$ ): $\mathrm{B}, \mathrm{Brown}-\mathrm{Norway}$ rats, diet approximately $12 \mathrm{mg} \mathrm{PN} \cdot \mathrm{HCl} / \mathrm{kg}$ (significant at $P<0.005$ ): $\mathrm{C}$. Wistar rats, diet $3 \mathrm{mg} \mathrm{PN} \cdot \mathrm{HCl} / \mathrm{kg}$

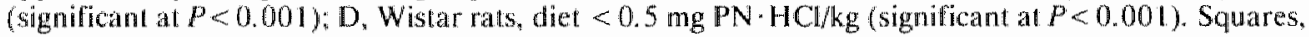
males, circles, females.

intercepts are observed. Slopes of regression lines are comparable for all Wistar diet groups whereas intercepts tend to be lower for a lower dietary vitamin B-6 level. Despite the higher vitamin B-6 level of the Brown-Norway diet (approximately $12 \mathrm{mg} / \mathrm{kg}$ ) than the Wistar control diet $(6 \mathrm{mg} / \mathrm{kg}$ ), the Brown-Norway intercept is similat to that of the Wistar control group. Brown-Norway slope value, however, is higher than Wistar value, which may be a strain-related feature.

When comparing the percentage of total muscle PLP bound to GP for method of calculation, see [10]) some differences between age groups are observed, but no apparent age-related trend is noted. Muscle PLP attributable to GP is $35-60 \%$ in Brown-Norway and $50-80 \%$ in Wistar rats. The remaining PLP, as well as any PMP present, is probably bound to other vitamin B-6 dependent enzymes, such as transaminases [11], or might be bound to proteins present abundantly, such as myoglobin. Observations on the different Wistar diet groups (Chapter 10) show that the percentage of PLP attributable to GP is not significantly influenced by vitamin B-6 intake. In accordance with this finding, no apo-GP can be demonstrated in any sample, including those from the Wistar rats fed the $<0.5 \mathrm{mg} \mathrm{PN} \cdot \mathrm{HCl} / \mathrm{kg}$ diet (Chapter 10). 
The correlation between (individual) gastrocnemius muscle PLP concentration and gastrocnemius muscle GP activity is significant in both male and female rats at various ages, in two strains of rats (Wistar and Brown-Norway), and in rats fed diets differing considerably in vitamin $B-6$ content. The ubiquity of the observed correlation between PLP level and GP activity suggests that these parameters are regulated by a similar mechanism, but not exclusively by a difference in vitamin B-6 (PLP) availability. Our observations in aging rats compare well with the observations made by Black et al. in young rats that had fasted for a short period ( $1-4$ days): a net loss of GP activity was observed and probably muscle PLP content was also reduced $[10,12]$. Black et al. concluded that the rate of protein degradation is an important factor in controlling muscle GP and hence muscle PLP concentration. An age-related increase in muscle GP turnover rate (either through a lower rate of synthesis or through a higher rate of breakdown) could well explain our observations. Although some studies indicate an age-related increase of total muscle protein turnover, data are generally conflicting [13]. Another explanation could be an age-related difference in physical activity. Muscle denervation, causing an extreme lowering of muscle activity, resulted in an increase of muscle GP turnover in mice [14] and a decrease of total muscle GP protein mass in rats [15]. Unfortunately, muscle PLP levels were not studied in these earlier experiments. GP turnover measurements were beyond the scope of our rat studies. Therefore, the interesting observations on the correlation between GP activity and PLP level in gastrocnemius muscle should be examined further in protein turnover studies. Studies into the correlation between GP turnover and PLP level (and its changes with age), or, on a total body basis, the correlation between nitrogen balance and vitamin B-6 status are expected to provide valuable additional information on the relation between vitamin B-6 and aging.

The age-related decrease in gastrocnemius muscle PLP concentration (and concomitantly in GP activity) could have functional consequences justifying further study. First, GP is a key enzyme in cellular energy production because it catalyzes the first step of intracellular glycogenolysis, cleaving glucose-1 - phosphate from glycogen [9]. A lower GP capacity could result in less efficient metabolic control of intra- and extracellular fuel flow. Second, muscle PLP (predominantly bound to GP) is the major vitamin B-6 body store. Muscle tissue accounts for approximately $40 \%$ of body weight, and approximately $80 \%$ of vitamin B-6 body store is located within the lean body mass (predominantly muscle tissue). If the decreasing PLP concentration of gastrocnemius muscle is representative of all (striated) muscle, this may reflect a decrease of vitamin B-6 body store with age.

In our experimental rats the hypothesis that lower gastrocnemius muscle PLP level reflects a lower vitamin B-6 body store could easily be tested by assessing total vitamin B-6 content of all tissues examined (data presented in Chapter 5) and adding the amount of vitamin B-6 present in the remaining carcass (Table 1). Total body vitamin B-6 pool (calculated as the total amount of PLP + PMP present) did not differ significantly between animals at the age of 7 months and those at the age of 31 months. A similar result was obtained in the experiment with $\left[{ }^{14} \mathrm{C}\right] \mathrm{PN}$ after biokinetic analysis of urinary excretion data (Chapter 9). Total body vitamin B-6 can 
Table 1. Vitamin B-6 body pool assessed biochemically in young and old Wistar rats (means of six animals per age and sex group).

\begin{tabular}{|c|c|c|c|c|c|c|c|}
\hline & \multirow[t]{2}{*}{$\operatorname{sex} 1$} & \multicolumn{2}{|l|}{ Age } & \multirow[t]{2}{*}{$\mathrm{SED}^{\prime}$} & \multicolumn{3}{|c|}{ Significance ${ }^{2}$} \\
\hline & & 7 months & 31 months & & $\operatorname{sex}$ & age & sexxage \\
\hline Body weight & $M$ & 355 & 431 & 28 & $<0.001$ & $<0.001$ & NS : \\
\hline (g) & $\mathrm{F}$ & 216 & 296 & & & & \\
\hline Carcass weight & M & 299 & 363 & 17 & $<0.001$ & 0.003 & NS \\
\hline (g) & $F$ & 176 & 242 & & & & \\
\hline Carcass PLP & $M$ & 13.15 & 9.67 & 0.66 & NS & $\therefore 0.001$ & NS \\
\hline$(\mathrm{nmol} / \mathrm{g})$ & $F$ & 12.55 & 11.02 & & & & \\
\hline Cancass PMP & $\mathrm{M}$ & 4.21 & 3.0 .4 & 0.30 & 0.025 & $<0.001$ & NS \\
\hline (nnnolig) & $\mathrm{F}$ & 4.80 & 3.49 & & & & \\
\hline Total carcass PLP+PMP & M & 5.16 & 5.05 & 0.32 & $<0.001$ & NS & NS \\
\hline$(\mu \mathrm{mol})$ & $\mathrm{F}$ & 3.06 & 3.48 & & & & \\
\hline Total body PLP + PMP & M & 6.03 & 5.86 & 0.37 & $<0.001$ & NS & NS \\
\hline$(\mu \mathrm{mol})$ & $\mathrm{F}$ & 3.66 & 4.15 & & & & \\
\hline
\end{tabular}

"M, male; $F$, female; SED, standard error of the difference between means; $N S_{x}$ not significant $(P>0.05)$.

2 Analysis of variance (ANOVA).

Table 2. Carcass composition of young and old Wistar rats (means of six animals per age and sex group).

\begin{tabular}{|c|c|c|c|c|c|c|c|}
\hline & \multirow[t]{2}{*}{$\operatorname{Sex}{ }^{1}$} & \multicolumn{2}{|l|}{ Age } & \multirow[t]{2}{*}{ SED } & \multicolumn{3}{|c|}{ Significance ${ }^{2}$} \\
\hline & & 7 months & 31 months & & $\operatorname{sex}$ & age & sex $\times$ age \\
\hline Carcass weight & $\mathrm{M}$ & 84.2 & 84.1 & 2.6 & NS: & NS & NS \\
\hline (\% ot body weight) & $F$ & 81.6 & 81.2 & & & & \\
\hline Carcass fat & $M$ & 39.6 & 70.6 & 18.2 & NS & 0.023 & $\mathrm{NS}$ \\
\hline (g) & $\mathrm{F}$ & 22.4 & 54.6 & & & & \\
\hline Carcass water & M & 184.6 & 204.4 & 10.6 & $<0.001$ & 0.005 & NS \\
\hline (E) & F & 104.5 & 132.0 & & & & \\
\hline Carcass protein & $M$ & 71.1 & 74.9 & 5.0 & $<0.001$ & NS & NS \\
\hline (g) & $\mathrm{F}$ & 42.3 & 48.9 & & & & \\
\hline Carcass ash & M & 13.41 & 14.90 & $0.9 \pi$ & $<0.001$ & 0.019 & NS \\
\hline (g) & $\mathrm{F}$ & 8.46 & 10.24 & & & & \\
\hline Recovery carcass & M & 103.2 & 100.5 & 2.2 & NS & NS & NS \\
\hline$(\%)$ & $F$ & 101.0 & 101.2 & & & & \\
\hline
\end{tabular}

1 M, malle; F, female; SED, standard error of the difference between means; NS, not significant $(P>0.05)$.

Analysis of variance (ANOVA).

also be estimated from data on gastrocnemius muscle PLP and PMP levels and body weight (Chapter 5) using the following formula:

$$
(\mathrm{PLP}+\mathrm{PMP}) \times 0.40 \times \mathrm{BW} / 0.80[\mu \mathrm{mol}]
$$


where (PLP + PMP) is gastrocnemius muscle PLP+PMP level in $\mu$ mol/g, 0.40 represents the estimated ratio of lean body mass to body weight, $\mathrm{BW}$ is body weight in $\mathrm{g}$, and 0.80 represents the estimated ratio of lean body mass vitamin B-6 store to total body vitamin B-6 store. This rough estimation results in average vitamin B-6 body stores of 5.34 and $5.04 \mu \mathrm{mol}$ for male Wistar rats at an age of 7 and 31 months, respectively, and of 3.35 and $3.86 \mu \mathrm{mol}$ for corresponding female rats. The observed variation in both body weight and gastrocnemius muscle B-6 vitamer level (Chapter 4) is such that the calculated differences between age groups are not significant. In our experimental animals values estimated as explained above are an underestimation of values actually measured (Table 1 ).

Although total body store of vitamin B-6 did not decrease with age, carcass vitamin B-6 vitamer levels (PLP and PMP) did. In extrapolating from the rat data to the human situation caution is called for: in our experimental animals the age-related decrease in carcass vitamin B-6 level was counteracted by an increase in absolute lean body mass, as illustrated by the increase in fat-free carcass weight (Table 2). In man, aging is associated with a progressive reduction of lean body mass $[16,17]$.

\section{Functional consequences of a long-term inadequate vitamin B-6 status}

Functional criteria of nutritional vitamin B-6 status have not yet been studied in great detail. Aging is associated with an increased prevalence of biochemical vitamin B-6 status parameters indicative of a low nutritional vitamin B-6 status in younger individuals (rat or man). Less is known about the functional consequences of a longterm (marginally) inadequate biochemical vitamin B-6 status.

The studies on the consequences of a diet-induced long-term lowered vitamin B-6 status in our experimental rats revealed the expected differences in biochemical vitamin B-6 status parameters and in vitamin B-6 dependent enzyme activities (Chapter 10). Furthermore, changes in PLP plasma clearance and plasma PLP formation towards lower PLP turnover with lower biochemical vitamin B-6 status were observed (Chapter 11). Functional consequences, which are more indirect consequences of low vitamin B-6 nutritional status than changes in biochemical status parameters, were much less discriminative. Only in the most severely vitamin B-6 deprived animals (which showed a markedly reduced body weight compared to controls) red blood cell parameters suggest a microcytic hypochromic anemia (Chapter 10). Furthermore, white blood cells show a significant shift towards less lymphocytes and more neutrophils in these animals. In accordance with this latter finding is the thymic involution in the vitamin B-6 deprived animals, characterized by a decreased cortex-to-medulla ratio due to lymphocyte depletion in the cortex. However, the experimental animals were not challenged (with an infection) to assess functional capacity of the immune system. Behavioral tests did not reveal significant diet-related differences (Chapter 12). 
The various rat experiments performed provide valuable insight into the relation between vitamin B-6 and aging additional to the body of knowledge already gathered by others. Because healthy animals were selected for the studies extrapolation of results to the human situation is valid only for healthy elderly. The possibly detrimental influence of pathological processes was not studied and is therefore not discussed here.

In the rat age-related changes were observed in vitamin B-6 distribution among body compartments. Concurrent changes occurred in vitamin B-6 metabolizing enzyme activities, but these latter changes were not explanatory for the shifts in vitamin $B-6$ body distribution. The age-related changes observed in the experimental animals did not resemble the changes induced by dietary deprivation of vitamin B-6. Extrapolation of these results to healthy elderly implies that several hypothesis, although until now generally accepted to be correct, need to be reconsidered.

The observed redistribution of vitamin B-6 body pools in rats appears to be at physiological age-related process which is likely to occur in man as well. Therefore, the plasma PL.P levels observed in healthy elderly can not be checked against normal ranges for young adults to assess vitamin B-6 status, because this parameter is not age-independent. Normal ranges for plasma PLP level in one age group are not necessarily valid in other age groups. When plasma PLP concentration is used as a vitamin B-6 status parameter normal ranges for the age of the population investigated, obtained independently, should be used. Consequently, readjustment of vitamin B-6 recommended dietary allowance (RDA) for the elderly on the basis of low plasma PLP levels compared to those of young adults is not justified.

Plasma PLP clearance was not increased in the aged experimental animals compared to young adult controls. Therefore the significant inverse correlation between plasma PLP concentration and serum AP activity observed in human volunteers at various ages [3] is not likely to present a causal relation between (high) AP activity and (low) plasma PLP level in elderly people.

Redistribution of vitamin B-6 body content implies increased concentrations in some tissues (as was observed for rat brain), but decreased concentrations in other tissues (for example rat gastrocnemius muscle). Because essential functions or organs might be involved this decrease in vitamin B-6 content is reason for concern. Based on the animal studies performed the age-related redistribution of total body vitamin B 6 is concluded to be related to changes in PLP binding capacity of tissue proteins. Protein PLP binding capacity in its turn is suggested to be regulated by changes in protein turnover. The relation between protein turnover and vitamin B-6 and its agerelated changes therefore deserve to be studied in more detail. Two approaches appear to be most promising. In animal experiments assessment of the age-related changes in the relation between muscle GP turnover and muscle PLP level are advocated. Unlike the situation in other tissues, in which vitamin B-6 is bound to a large variety of proteins, the vitamin B-6 present in striated muscle tissue, mostly 
PLP, is predominantly bound to one single protein, glycogen phosphorylase. If experiments on human volunteers are preferred, research into the relation between total body nitrogen balance and vitamin B-6 status at various ages is expected to further elucidate the relation between vitamin B-6 and aging.

An important finding emerging from the vitamin B-6 study in aging rats is the agerelated decrease in gastrocnemius muscle vitamin B-6 concentration. Muscle tissue is the major vitamin B-6 body depository, containing approximately $80 \%$ of the total vitamin B-6 body pool. If gastrocnemius muscle tissue is representative of total lean body mass (which is mostly muscular tissue) total body vitamin B-6 content may well decrease considerably with age. In the experimental animals total body vitamin B-6 content was assessed both biochemcially and biokinetically. Neither approach revealed a significant difference in vitamin B-6 body pool between young adult and senescent rats. This apparently reassuring finding in rats can not be translated directly to man. In the senescent animals studied muscle and carcass vitamin B-6 level were lower but lean body mass was higher than in young adult rats. This increase in lean body mass counteracted the observed decrease in muscle vitamin B-6 concentration. In contrast to the age-related increase in the rats studied, lean body mass generally decreases with age in man. As a result, the total body pool of vitamin B-6 is expected to decrease with age in man. This decrease may be prevented by increasing either muscle vitamin B-6 level, via readjustment of vitamin B-6 RDA for the elderly, or lean body mass, for example via recommendation of higher activity level. However, it is still unknown under what circumstances the vitamin B-6 present in muscle tissue becomes available to other tissues. Before measures are taken to prevent the age-related decrease of total body vitamin B-6 more research into the mechanism of vitamin B-6 release from the muscle tissue pool is needed. In this respect experiments with isolated perfused animal (rat) hind legs are suggested.

The functional parameters of vitamin B-6 deficiency studied, red and white blood cell parameters and behavioral test results, did not show adequate discriminative power between rats differing in vitamin B-6 status. Recent observations suggest that plasma or serum homocysteine concentration is a promising functional parameter. Evidence has been obtained that an increased serum homocysteine level (homocysteinemia) is a risk factor for cardiovascular disease [18]. Metabolism of homocysteine partly occurs via a vitamin B-6 dependent enzyme (Chapter 2 ). In the experimental rats plasma homocysteine was not studied. Microscopic evaluation of tissues from animals fed diets containing low levels of vitamin B-6 form weaning revealled no indication whatsoever of a higher incidence of vascular lesions. However, the rat is not a good model for (cardio)vascular disease in man because it is not prone to atherosclerotic processes. Whether homocysteinemia is an independent risk factor from other major risk factors for vascular diease in man (such as hyperlipidemia, hypertension, smoking) is currently being investigated in a European multicenter case-control investigation [19]. Whether an increased plasma homocysteine level in man is correlated with suboptimal nutritional status of (among others) vitamin B-6 is currently being investigated at the TNO Toxicology and Nutrition Institute in Zeist, Netherlands. If a correlation between homocysteinemia 
and marginal vitamin B-6 nutritional status is observed in man, controlled clinical trials are required to examine whether reduction of plasma homocysteine levels by vitamin B-6 suppletion results in a lower incidence and severity of vascular disease. If So, vilamin $\mathrm{S}-6 \mathrm{RDA}$ may be reconsidered. At present no justification is available to increase RDAs for vitamin B-6, not even for the elderly.

\section{References}

1. Middle 6 on III HM. Intestinal hydrolysis of pyridosal-5' phosphate in witro and in wivo in the rat Effects of amino acids and oligopeptides. Digest Dis Sci 1990;35: 113-20.

2. Ribaya-Mercado JD, Otradovec CL. Russell RM, Samloff IM. Atrophic gastritis does not impair vitamin B.6 status in the elderly. Gastroenterology 1987:93:222 3 .

3. Kant AK. Moser-Veillon ${ }^{5} \mathrm{~B}, \mathrm{R}$ eynolds RD. Ellect of age on changes in plasma, erythrocyte, and urinary B-6 witamers alter an oral vitamin B-6 Joad. Am J Clin Nutr 1988;48: 1284-90.

4. Keating $R$, Jones $d$, Elveback $L_{\text {. }}$ Randall $R$. The relation of age and sex to distribution of values in healthy adults of serum calcium, inorganic phosphorus, magnesium, alkaline phosphatase, total protein, albumin, and blood urea. J Lab Clin Med 1969;73: 825-3.4.

5. Stanulovic M, Jeremic $V$, Leskovar $V$. Chaykin S. New pathway of conversion of pyridoxal to 4-pyridoxic acid. Enzyme 1976;21:357-69.

6. Merrill AH, Henderson JM. Wang E, McDonald BW, Millikan WJ. Metabollism of vitamin B-6 by human liver. J Nutr 1984;114:1664-74.

7. Lumeng L, Brashear RE, L.i T-K. Pyridoxal-5'-phosphate in plasma: source, protein-binding and cellular transport. J Lab Clin Med 1974;84:334-43.

8. Anderson BB, Newmark PA, Rawins M, Green R. Plasma binding of vitamin B-6 compounds. Nature 1974:250:502-4.

9. Krebs EG \& Fisher EH. Phosphorylase and related enzymes of glycogen metabolism. Vitam Horm 1964:22: $399-410$.

10. Black AL, Guirard BM. Snell EE. Increased muscle phosphorylase in rats fed high level of vilamin B-6. J Nutr 1977:107: 1962-8.

11. Russell LE, Bechtel PJ, Easter RA. Effect of deficient and excess dietary vilamin B-6 on amino transaminase and glycogen phosphorylase activity and pyridoxal phosphate content in two muscles from postpubertal gilts. J Nuttr 1985:115: 1124-35.

12. Black AL. Guirard BM. Snell EE. Behavior of muscle phosphorylase as a reservoir for vitamin B-6 in the rat. I Nutr 1978:108:670-7.

13. Mckay MJ. Bond J. Protein and amino acids. In: Chen LH, Ed. Nutritional aspects of Aging, Vol. 1. Boca Raton, FL: C.R. C. Press, 1986:173-94.

14. Begnon RJ. Fairhurkt D. Coakson EJ. Turnover of skeletal muscle glyogen phosphorylase. Bioned Biochim Acta 1986:45: 1619-25.

15. Lawrence Jr JC. Smith RL. Phosphorylase kimase isozymes and phosphorylase in denervated skeletal musdes. Muscle Nerve 1990;13:133-7.

16. Shock NW. Age changes in some physiological processes. Geriatrics 1957:12:40m8.

17. Munro HN. Nutrition-related problems of middle age. Proc Nutr Soc 1984:43:281-8.

18. Clarke R, Daly L. Robinson Ka Naughren $\mathbb{E}$. Cahalane S. Fowlen B Graham I. Hyperthomocysteinemix: An independent risk Gactor for vascular disease. Now Engl J Med $1991: 324: 1149.55$.

19. Robinson K. Homocystemamia and vascular disense. Procedings of an EC Comac Epidemiology Expert Group workshop held in Dublin on 2 and 3 February 1989. Luxembourg: Office for Official Publications of the European Communties 1990 (Publication no. CD-NA$12834-E N-C)$. 


\section{Samenvatting}

\section{Vitamine B-6 en veroudering: Onderzoek bij de rat}

Vitamine B-6 is een essentiële voedingsstof nodig voor de normale groei en ontwikkeling van de mens en van alle tot nu toe onderzochte diersoorten. Pyridoxalfosfaat, bekend onder de (Engelse) afkorting PLP, is de actieve vorm van vitamine B-6. PLP is cofactor bij vele metabole processen, met name transamineringsen decarboxyleringsreacties. Als zodanig is PLP betrokken bij onder meer aminozuurmetabolisme en neurotransmittersynthese.

Bij onderzoek naar de (biochemische) vitamine B-6 status van ouderen valt de hoge incidentie van een lage PLP-spiegel in plasma op in vergelijking met die van jong-volwassenen. Dit blijkt niet alleen verklaard te kunnen worden door een lagere vitamine B-6 inneming. In een beperkt aantal studies zijn aanwijzingen gevonden voor leeftijdsafhankelijke veranderingen in vitamine B-6 metabolisme en vitamine B-6 kinetiek. Er is onder meer geconstateerd dat orale vitamine B-6 suppletie niet bij alle ouderen een verbetering te zien geeft van de biochemische vitamine B-6 status.

Het doel van het in dit proefschrift beschreven onderzoek, "vitamine B-6 en veroudering', was na te gaan waardoor de PLP-spiegel in plasma daalt bij veroudering. Daarnaast werd onderzoek gedaan naar de functionele consequenties van een chronische vitamine B-6 deficiêntie. Gekozen werd voor een dierexperimentele benadering met de rat als model voor de mens. Een cohort Wistarratten werd vanaf speenleeftijd op een in alle opzichten adequaat voer gehouden en gedurende $2 \frac{1}{2}$ jaar gevolgd. Onderzocht werden (veranderingen in) vitamine $B-6$ status, verdeling van vitamine $B-6$ over het lichaam en activiteiten van vitamine B-6 metaboliserende enzymen bij gezonde ratten. Dezelfde gegevens werden verzameld van ratten van een andere stam, Brown-Norway, van verschillende leeftijd (van 6 maanden tot 3 jaar). Teneinde interpretatie van de verkregen gegevens te vereenvoudigen werden dezelfde karakteristieken ook onderzocht bij Wistar-ratten die vanaf speenleeftijd waren gehouden op een voer met een lager gehalte aan vitamine B-6 (respectievelijk $10 \%$ en $50 \%$ van de aanbeveling).

Naast de beschreven biochemische in vitro benadering werd een biokinetische in vivo benadering toegepast. De totale lichaamsklaring van PLP enerzijds en de synthesecapaciteit van PLP anderzijds werden vergeleken in jonge en oude ratten. Ter vereenvoudiging van de interpretatie van de resultaten werden dezelfde experimenten uitgevoerd met vitamine B-6 deficiënte dieren. De resultaten werden geverifieerd via in vitro perfusie van levers van jonge en oude ratten. Langzame in vivo processen werden onderzocht in experimenten met radioactief gemerkt vitamine B-6. In jonge en oude dieren werden de distributie in en de elliminatie uit onder andere spierweefsel onderzocht. 
Functionele consequenties van een chronisch marginale tot deficiënte vitamine B-6 status werden onderzocht in dieren gehouden op voer met een verlaagd vitamine B-6 gehalte ten opzichte van de aanbeveling. De onderzochte karakteristieken waren mortaliteit, macroscopische en microscopische afwijkingen aan organen, groei en gewicht, voerverbruik, klinisch-chemische parameters, vitamine B-6 athankelijke enzymen, immunologische parameters en gedrag.

Mogelijke oorzaken van een dalende PLP-spiegel in plasma bij veroudering zijn:

- lagere vitamine B-6 inneming;

- verminderde absorptie van vitamine $B-6$ na consumptie;

- hogere PLP-klaring;

- lagere PLP-synthese;

- verschuivingen in de verdeling van vitamine B-6 tussen organen;

- hogere 'turnover'.

In de onderzochte ratten (op adequaat voer) bleek, net als bij de mens, de PLPspiegel in plasma leeftijdsafhankelijk te dalen. Het voerverbruik echter - en dus de vitamine $\mathrm{B}-6$ consumptic - bleek constant. Uit de resultaten van experimenten met radioactief gemerkt vitamine B-6 bleek dat de absorptie na orale toediening vrijwel volledig is, zowel bij jonge als bij oude dieren. Hoewel de in vitro activiteit van vitamine B-6 metaboliserende enzymen veranderde, vertoonden noch de PLP-klaring in plasma noch de PLP-synthese in plasma leeftijdsafhankelijke verschillen in in vivo experimenten. Wel bleek een verschuiving in de lichaamsverdeling van vitamine B-6 op te treden bij oudere dieren. In Wistar-ratten daalde het vitamine B-6 gehalte in plasma, nieren en spierweefsel, bleef het vrij constant in lever, maar steeg het in hart en hersenen. In Brown-Norway-ratten vertoonden plasma, nieren, thersenen en spierweefsel een daling, maar hart en lever een stijging van de vitamine B-6 spiegel. Er werd bevestiging gevonden van de hypothese dat deze verschuivingen te maken hebben met veranderingen in de bindingscapaciteit voor vitamine B-6 (aan eiwitten) en dus met veranderingen in 'turnover' van weefseleiwitten. De totale lichaamsvoorraad witamine B-6 bleek niet te verschillen tussen jonge en oude dieren. In experimenten met radioactief gemerkt vitamine $\mathrm{B}-6$ werden geen verschillen gevonden in vitamine B-6 'turnover'.

De dieren die op voer met een beperkt gehalte aan vitamine B-6 waren gehouden vertoonden de verwachte daling van de biochemische vitamine B-6 status en van de vitamine B-6 spiegels in weefsels, en een lagere activiteit van vitamine B-6 afhankelijke enzymen. Verder werden een lagere PLP-klaring en een hogere PLPsynthese waargenomen. Slechts de dieren die op voer met $10 \%$ van de aanbevolen hoeveelheid vitamine B-6 waren gehouden vertoonden een lager lichaamsgewicht dan even oude controledieren. Behalve haaruitval en een vorm van dermatitis die kenmerkend is voor vitamine B-6 deficiëntie bij de rat werden geen aan vitamine B-6 deficiëntie toe te schrijven afwijkingen gevonden. De mortaliteit onder deze dieren verschilde ook niet tussen de voergroepen. Alleen bij de dieren gehouden op voer met $10 \%$ van de aanbevolen hoeveelheid vitamine B-6 werd een bloedbeeld wargenomen overeenkomend met microcytaire hypochrome anemie. Het wit 
bloedbeeld van deze dieren vertoonde een verschuiving naar meer neutrofielen ten koste van lymfocyten. Tegelijkertijd werd involutie van de thymus waargenomen. In de gedragstesten werden geen verschillen waargenomen tussen dieren gehouden op de verschillende voeren.

Wanneer de resultaten van het onderzoek bij de (gezonde) verouderende rat worden geëxtrapoleerd naar de (gezonde) verouderende mens blijken een aantal dogma's betreffende vitamine B-6 niet houdbaar. Ten eerste is het PLP-gehalte in plasma geen leeftijdsonafhankelijke parameter voor de vitamine B-6 status vanwege de verschuivingen in de verdeling van vitamine $B-6$ over het lichaam ten koste van plasma. Ten tweede blijkt de significante inverse correlatie tussen de PLP-spiegel in plasma en serumactiviteit van alkalische fosfatase (een vitamine B-6 metaboliserend enzym) bij veroudering geen oorzakelijk verband in te houden daar de totale lichaamsklaring van PLP niet verandert met de leeftijd.

Een belangrijke bevinding van het onderzoek bij de rat is de daling van het vitamine $\mathrm{B}-6$ gehalte in spierweefsel bij veroudering. Daar ongeveer $80 \%$ van de lichaamsvoorraad aan vitamine B-6 zich in de spieren bevindt kan een daling van het gehalte vitamine B-6 in de spieren een daling van de lichaamsvoorraad inhouden. Bij de rat bleek de totale lichaamsvoorraad vitamine B-6 niet te verschillen tussen jonge en oude dieren, omdat de daling van het gehalte aan vitamine B-6 in de spieren werd gecompenseerd door een toename van de massa spierweefsel. Bij de mens daalt echter de hoeveelheid spierweefsel gemiddeld bij veroudering en ligt dus een daling van de lichaamsvoorraad vitamine B-6 voor de hand. Voordat maatregelen worden getroffen om deze daling tegen te gaan (bijvoorbeeld door een hogere dagelijkse vitamine $\mathbb{B}-6$ consumptie of meer lichaamsbeweging aan te bevelen) dient eerst ondersteunend onderzoek te worden verricht.

Hoe de afgifte van vitamine B-6 door spierweefsel wordt gereguleerd is niet bekend. Experimenten met in vitro perfusie van spierweefsel, bijwoorbeeld in de geisoleerde achterpoot van de rat, lijken een goede benadering om dit te onderzoeken. De relatie tuissen 'turnover' van weefseleiwit en weefselspiegel van vitamine B-6 kan worden onderzocht aan de hand van het enzym glycogeenfosforylase. Dit enzym, aanwezig in spierweefsel, is daar het belangrijkste vitamine B-6 bindend eiwit. Wanneer experimenten met mensen gewenst zijn kan onderzoek naar de relatie tussen stikstofbalans en vitamine B-6 status (en veranderingen hierin met de leefiijd) belangrijke informatie leveren.

De in het project 'vitamine B-6 en veroudering' verkregen resultaten geven vooralsnog geen aanleiding tot het aanbevelen van een hogere dagelijkse vitamine B-6 consumptie voor ouderen. 



\section{Curriculum vitae}

Wilhelmina Bode werd geboren op 24 juni 1961 te Rotterdam. Van augustus 1973 tot juni 1979 volgde zij voorbereidend wetenschappelijk onderwijs (ongedeeld VWO) aan de Nassau Scholengemeenschap te Breda. Vanaf september 1979 studeerde zij farmacie aan de Rijksuniversiteit Leiden. Het propaedeutisch examen werd afgelegd in 1980, waarna zij in 1982 het kandidaatsexamen haalde met het judicium cum laude. Tijdens de doctoraalfase van de studie farmacie was zij drie maanden werkzaam als student-assistent bij het practicum kwalitatieve analyse. Tevens is zij lid geweest van de onderwijscommissie en van de Kommissie Invoering Tweefasenstructuur (KITS) van de Subfaculteit Farmacie en student-lid van de subfaculteitsraad. Gedurende anderhalf jaar was zij student-lid van het bestuur van de Subfaculteit Farmacie. Van juli tot en met december 1984 doorliep zij een onderzoeksstage bij de Afdeling Organische Synthese van de Subfaculteit Scheikunde te Leiden. Onder leiding van W. Buys en onder begeleiding van dr. N. Vermeulen werkte zij mee aan het onderzoeksproject 'glutathion-S-transferase'. Van januari tot en met december 1985 verbleef zij in San Francisco in de Verenigde Staten als assistent-onderzoeker bij de Faculteit Farmacie van de Universiteit van Californië in San Francisco. Onder leiding van dr. B. -A. Hoener en onder begeleiding vanuit Nederland van prof. dr. D.D. Breimer werkte zij daar mee aan het project 'nitrofurantoine dispositie in de geïsoleerde, geperfuseerde rattelever".

Terug in Nederland behaalde zij in januari 1986 het doctoraalexamen farmacie. In verband met de opheffing van de Subfaculteit Farmacie in Leiden studeerde zij verder aan de Subfaculteit Farmacie van de Rijksuniversiteit Groningen. In september 1986 werd zij aangesteld als wetenschappelijk assistent in tijdelijke dienst bij de Faculteit Gezondheidswetenschappen van de Rijksuniversiteit Limburg, en voor de duur van de aanstelling gestationeerd op het CIVO-Instituut voor Toxicologie en Voeding TNO te Zeist, bij de Afdeling Klinische Biochemie. Aldaar werd het onderzoek verricht waarvan dit proefschrift verslag doet. Sinds november 1990 werkt zij als wetenschappelijk beoordelaar van registratie-aanvragen van geneesmiddelen in opdracht van het College ter Beoordeling van Geneesmiddelen bij het Laboratorium voor Geneesmiddelen en Medische Hulpmiddelen (LGM) van het Rijksinstituut voor Volksgezondheid en Milieuhygiëne (RIVM) te Bilthoven. Bij het LGM werd zij tevens toegevoegd aan het project 'ß-blokker intoxicatie', waarin zij toxicokinetisch onderzoek verricht. Vanaf 1973 speelt zij (fanatiek) klassiek gitaar. 